$$
\text { UNIVERSIDADE DE SÃO PAULO - USP }
$$

ESCOLA DE ENGENHARIA DE SÃO CARLOS - EESC

DEPARTAMENTO DE HIDRÁULICA E SANEAMENTO - SHS

\title{
REATOR ANAERÓBIO SERIAL (RAS) APLICADO NO PROCESSAMENTO DE VINHAÇA DE CANA-DE-AÇÚCAR
}

\author{
VINICIUS MASQUETTI DA CONCEIÇÃO
}

VERSÃO CORRIGIDA

São Carlos

2016 

UNIVERSIDADE DE SÃO PAULO - USP

ESCOLA DE ENGENHARIA DE SÃO CARLOS - EESC

DEPARTAMENTO DE HIDRÁULICA E SANEAMENTO - SHS

\title{
REATOR ANAERÓBIO SERIAL (RAS) APLICADO NO PROCESSAMENTO DE VINHAÇA DE CANA-DE-AÇÚCAR
}

\begin{abstract}
Tese apresentada à Escola de Engenharia de São Carlos, da Universidade de São Paulo, como parte dos requisitos para a obtenção do título de Doutor em Ciências: Engenharia Hidráulica e Saneamento.
\end{abstract}

Orientador: Dr. Eduardo Cleto Pires

VERSÃO CORRIGIDA

São Carlos 
AUTORIZO A REPRODUÇÃO TOTAL OU PARCIAL DESTE TRABALHO, POR QUALQUER MEIO ÇONVENCIONAL OU ELETRÔNICO, PARA FINS DE ESTUDO E PESQUISA. DESDE QUE CITADAA FONTE.

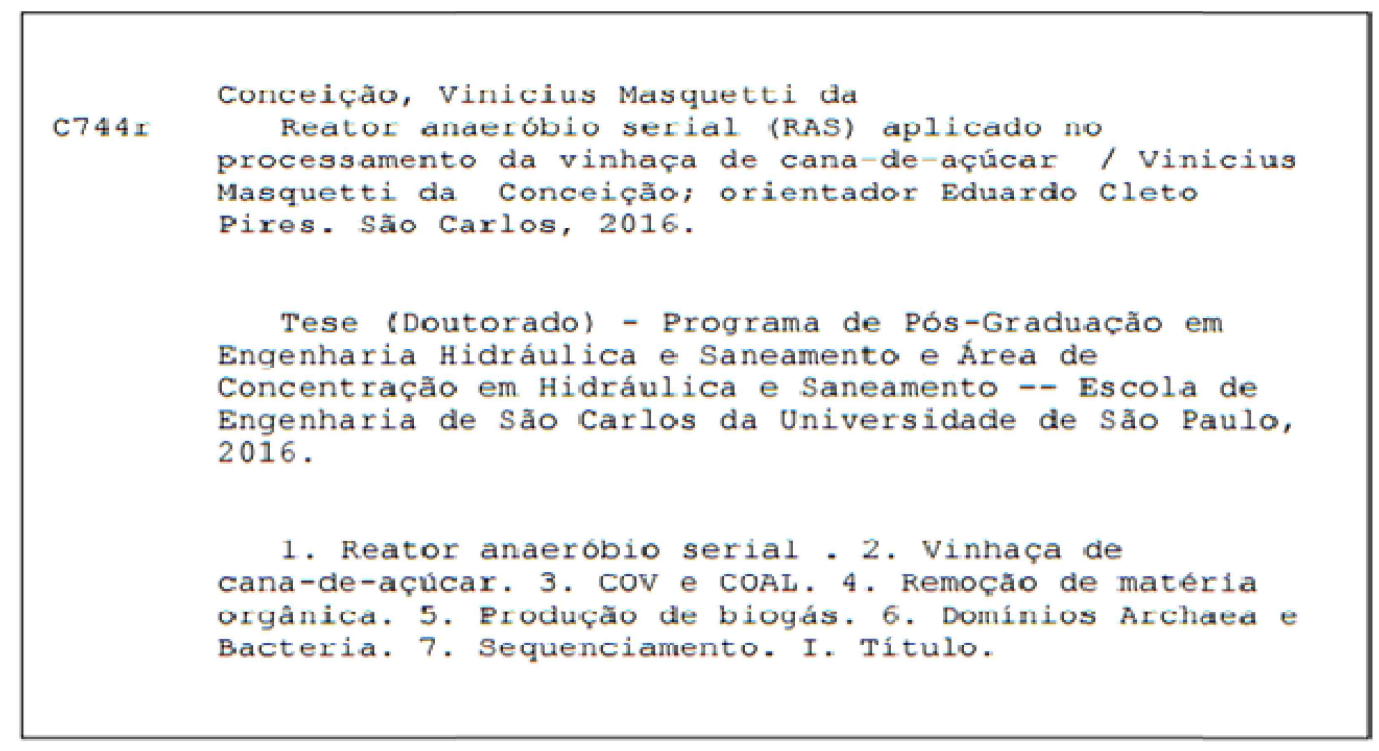


FOLHA DE JULGAMENTO

Candidato: Tecnólogo VINÍCIUS MASQUETTI DA CONCEIÇÃO.

Título da tese: "Reator anaeróbio serial (RAS) aplicado no processamento da vinhaça de cana-de-açúcar".

Data da defesa: 09.12.2016.

Comissāio Julgadora:

Prof. Titular Eduardo Cleto Pires

(Orientador)

(Escola de Engenharia de São Carlos/EESC)

Prof. Titular Eugenio Foresti

(Escola de Englenharia de São Carlos/EESC)

Profa. Dra. Márcia Helena Rissato Zamariolli Damianovic (Escola de Engentharia de Söo Carlos/EESC)

Prof. Dr. Flávio Bentes Freire

(Universidade Tecnológica Federal do Paraná/UTFPR)

Prof. Dr. Ariovaldo José da Silva

(Universidade Estadual de Compinas/UNICAMP)

\section{Resultado:}
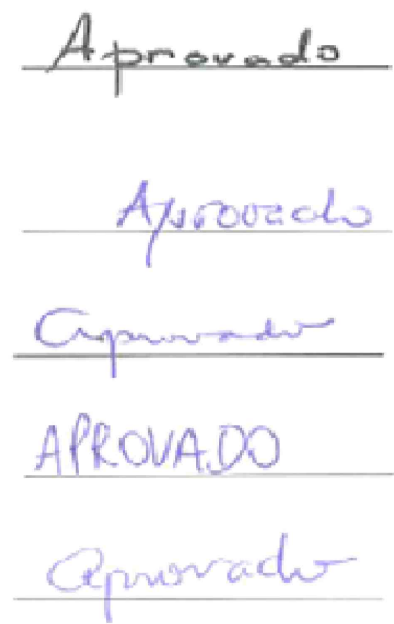

Coordenadora do Programa de Pós-Graduaçāo em Engenharia Hidrúulica e Saneamento:

Profa. Associada Maria Bernadete A. Varesche Silva

Presidente da Comissão de Pós-Graduação:

Prof. Associado Luis Fernando Costa Alberto 
Aos meus pais Ana e Pedro, aos meus irmãos Alexandre e Laisa e, a minha afilhada Mariana, a quem eu amo tanto e, que sempre estiveram ao meu lado me apoiando, dando forças e aconselhando nos momentos em que mais precisei, para alcançar esse objetivo.

Agradeço e dedico. 


\section{Agradecimentos}

Agradeço primeiramente a Deus pela minha vida e por toda força concedida nos momentos de dificuldades e atribulações, pois sempre esteve ao meu lado me dando forças.

Aos meus pais Ana e Pedro, os quais eu amo com todas as minhas forças, por terem me dado a vida, me ensinado a ser quem eu sou, e por todo apoio para chegar até aqui e continuar seguindo em frente.

Aos meus irmãos, Laisa e Alexandre, meus grandes e eternos amigos e a quem eu amo tanto. À minha sobrinha e afilhada Mariana, minha eterna princesinha a quem eu amo tanto.

A toda a minha família, pelo encorajamento, solidariedade e força no decorrer do doutorado.

Ao meu orientador Eduardo Cleto Pires, pelo apoio e confiança no decorrer do desenvolvimento do trabalho. Obrigado pela orientação e estimulo para a realização deste trabalho, e ao longo do estágio docência no Programa de Aperfeiçoamento de Ensino (PAEUSP). Obrigado por ser um dos incentivadores da realização da minha graduação em engenharia civil em paralelo com o doutorado.

À Dr ${ }^{\mathrm{a}}$. Eloisa Pozzi (Elô) e Dr ${ }^{\mathrm{a}}$. Isabel Sakamoto (Bel), obrigado pela amizade, por todas as dicas e informações sempre valiosas prestadas no decorrer da pesquisa, por todo apoio e força concedida nos diversos momentos.

Aos alunos colegas do LPB/EESC/USP, em especial Marcus Vinicius Freire, Ahmad Fiaz, Janja, Carol, Inês, e a todos que de alguma forma contribuíram para a realização deste trabalho. 
Aos professores Dr. Eugênio Foresti, Drª . Márcia Damianovic e Dr. Marcelo Zaiat pelos ensinamentos, pelas dicas valiosas na realização deste trabalho e pelo exemplo de mestres. À Dra $^{\text {a }}$ Valéria Del Nery pelas dicas imprescindíveis na realização dos procedimentos experimentais.

Aos funcionários do SHS/USP por estarem sempre prontos a ajudar, em especial à Sá, Rose e Priscila. Aos funcionários do Campus 2, em especial à Silvana (Sil), pelo carinho e amizade; a Dona Rosa, Fátima, Andréia e Sr. Antônio.

Ao professor Dr. Flávio Bentes Freire por toda amizade, apoio e confiança repassada na construção da minha carreira acadêmica desde à iniciação científica.

Aos amigos de São Carlos, André Rodrigues (Angel), Mônica, Roger, Potter e tantos outros, obrigado pela amizade, por todos os momentos de risadas e pela força nos momentos de fraqueza.

Aos amigos e colegas da graduação em engenharia civil do UNICEP, em especial à Grasiela (Gra), Adriele (Dri), Ana Flávia, Laira, Vicente, Rogério, Hermes, obrigado pela amizade e pelo apoio.

Aos professores da graduação em engenharia civil do UNICEP, pelos ensinamentos e pela compreensão nos momentos de dificuldades, em especial a professora $\operatorname{Dr}^{\mathrm{a}}$. Luciana M. B. Figueiredo pela amizade e pela pronta disponibilidade em sempre me ajudar.

À Fundação de Amparo à Pesquisa do Estado de São Paulo (FAPESP), pelo apoio à pesquisa, por meio da bolsa de doutorado (Processo 2014/19561-5), e ao Conselho Nacional de Desenvolvimento Científico e Tecnológico (CNPq), pelo apoio inicial. 
O Senhor é meu pastor, nada me faltará. Deitarme faz em pastos verdejantes; guia-me mansamente a águas tranquilas.

Refrigera a minha alma; guia-me pelas veredas da justiça, por amor do seu nome.

Ainda que eu ande pelo vale da sombra da morte, não temerei mal algum, porque tu estás comigo; a tua vara e o teu cajado me consolam.

Preparas uma mesa perante mim na presença dos meus inimigos, unges com óleo a minha cabeça, o meu cálice transborda.

Certamente que a bondade e a misericórdia me seguirão todos os dias da minha vida, e habitarei na casa do Senhor por longos dias.

(Salmo 23) 



\section{Resumo}

CONCEIÇÃO, V.M. (2016). Reator anaeróbio serial (RAS) aplicado no processamento de vinhaça de cana-de-açúcar. São Carlos, 2016. 185 p. Tese (Doutorado) - Escola de Engenharia de São Carlos, Universidade de São Paulo - EESC/USP.

O objetivo deste trabalho foi estudar a aplicação de reator anaeróbio serial (RAS) no processamento de vinhaça de cana-de-açúcar para a remoção de matéria orgânica e produção de biogás, submetido ao aumento gradativo de carregamento orgânico. Para tanto, foi utilizado um reator composto por quatro câmaras em série denominadas $\mathrm{C} 1$, C2, C3 e C4, com capacidade de $5 \mathrm{~L}$ cada, totalizando um volume de $20 \mathrm{~L}$. A primeira etapa do trabalho (Etapa 1) consistiu na operação e monitoramento do reator RAS partindo-se da aplicação da carga orgânica volumétrica (COV) de $0,5 \mathrm{~kg}$ DQO m${ }^{-3} \cdot \mathrm{d}^{-1}$ até a obtenção da COV de 2,5 $\mathrm{kg}$ DQO m $\mathrm{m}^{-3} \cdot \mathrm{d}^{-1}$. Na segunda etapa (Etapa 2) foram operados reatores em batelada sequencial, simulando a operação contínua do reator RAS, visando estudar o efeito do aumento de taxas de carregamento orgânico aplicado. $\mathrm{O}$ reator RAS operou sob baixos valores de $\mathrm{COV}_{\text {global }}$ e $\mathrm{COAL}_{\text {global }}$ aplicados na Etapa 1, obtendo-se máximas de $2,50 \mathrm{~kg}$ DQO $\mathrm{m}^{-3} \cdot \mathrm{d}^{-1}$ e $\quad 0,167 \quad \mathrm{~kg} \quad \mathrm{STV} \quad \mathrm{m}^{-3} \cdot \mathrm{d}^{-1}$, respectivamente. Os resultados obtidos da Etapa 1 indicam satisfatória remoção global média de matéria orgânica na forma de DQO, superiores a $90 \%$, propiciada pela adaptação da biomassa ao longo dos reatores sequenciais. O metano apresentou-se como o gás predominante na composição do biogás produzido, com valores acima de $75 \%$, que confirmam o estabelecimento do sistema metanogênico pleno. Em todos os compartimentos dos reatores sequenciais verificou-se maior abundância relativa para os domínios Archaea e Bacteria os gêneros Methanosaeta, produtores de metano e, T78, responsável pela degradação de açúcares, respectivamente. Principalmente para os reatores C3 e C4, observou-se adaptação de algumas populações para ambos os domínios Bacteria e Archaea indicado pelo menor índice de diversidade e aumento da dominância. O aumento das taxas de carregamento orgânico aplicado ao lodo, estipuladas nos ensaios em batelada na Etapa 2, propiciou o aumento dos valores de carga orgânica aplicada para todos os reatores. Com o aumento do carregamento orgânico aplicado, observa-se o aumento e acúmulo de ácidos orgânicos para todas as fases dos ensaios, principalmente o acético. A produção de metano foi significativa na operação dos reatores em batelada, principalmente em C1. De forma geral, os resultados obtidos demonstraram o bom desempenho do processamento da vinhaça de cana-deaçúcar em reator compartimentado tipo RAS para a remoção de matéria orgânica e produção de biogás.

Palavras-chave: Reator anaeróbio serial; Vinhaça de cana-de-açúcar; COV e COAL; Remoção de matéria orgânica; Produção de biogás; Diversidade microbiana; Sequenciamento. 


\section{Abstract}

CONCEIÇÃO, V. M. (2016). Anaerobic serial reactor (ASR) applied in the processing sugarcane stillage. São Carlos, 2016. 185 p. Thesis (Ph.D.) - School of Engineering of São Carlos, University of São Paulo - EESC/USP.

The aim of this study was to investigate the application of an anaerobic serial reactor (ASR) in the sugarcane stillage processing for the removal of organic matter and biogas production, submitted to the gradual increase in organic loading rate. ASR reactor consisted of four reactors operated in series $(\mathrm{C} 1, \mathrm{C} 2, \mathrm{C} 3$ and $\mathrm{C} 4)$, each with a reaction volume of $5 \mathrm{~L}$ (total volume of $20 \mathrm{~L}$ ). The first step (Step 1) consisted of reactor operation and monitoring; organic loading rate was gradually increased from $0.5 \mathrm{~kg}$ COD m ${ }^{-3} \mathrm{~d}^{-1}$ up to $2.5 \mathrm{~kg} \mathrm{COD} \mathrm{m}^{-3} \mathrm{~d}^{-1}$. In the second step (Step 2), sequential batch reactors were operated, simulating the continuous ASR reactor operation, aiming to study the effect of the increase of organic load applied to sludge (OLS). The ASR reactor operated under low values of $\mathrm{COV}_{\text {global }}$ and $\mathrm{COAL}_{\text {global }}$ applied in Step 1, obtaining a maximum $2.50 \mathrm{~kg} \mathrm{COD} \mathrm{m} \mathrm{d}^{-3}$ and $0.167 \mathrm{~kg} \mathrm{TVS} / \mathrm{m}^{-3} \mathrm{~d}^{-1}$, respectively. The results obtained from Step 1 indicated satisfactory removal of the global average organic matter in the form of COD more than $90 \%$, caused by adaptation of the biomass along the sequential reactors. Methane appeared to be the predominant gas in biogas composition, with values above $75 \%$, which confirmed the establishment of the full methanogenic system. In all compartments of the sequential reactors, there was a higher relative abundance for the domains Archaea and Bacteria of the genera Methanosaeta, methane producers, and 778 , which is responsible for degradation of sugars, respectively. Especially for the reactors $\mathrm{C} 3$ and $\mathrm{C} 4$, the adaptation of some populations for both domains Bacteria and Archaea indicated was observed by the lower diversity index and increase in dominance. The increase of the organic loading rates applied to the sludge, as established in the batch tests, increased the organic load values applied to all reactors. With the increase of organic loading applied, an increase in the accumulation of organic acids, mainly acetic, for all stages and the batch tests. Methane production was significant in the operation of batch reactors, mainly in the $\mathrm{C} 1$. In general, the results obtained showed good performance of the processing of the sugarcane stillage in serial reactor (ASR) for the removal of organic matter and biogas production.

Keywords: Anaerobic serial reactor; Sugarcane stillage; OLR and OLS; Organic matter removal; Biogas production; Microbial diversity; Sequencing. 


\section{Lista de Figuras}

FIGURA 3.1. Sequencias metabólicas e grupos microbianos envolvidos no processo de biodigestão anaeróbia 11

FIGURA 3.2. Desenho esquemático de um reator anaeróbio compartimentado .19

FIGURA 4.1. Fluxograma simplificado da metodologia empregada na condução do trabalho.

FIGURA 4.2. Esquema de montagem do reator anaeróbio serial (RAS) utilizado

FIGURA 4.3. Componentes do reator RAS utilizado. (A: vista frontal do reator; B:

tubulações condutoras do efluente; $\mathrm{C}$ : tela de retenção de sólidos; D: separador .33

FIGURA 4.4. Esquema dos ensaios utilizando frascos reatores operados em batelada sequencial processando vinhaça

FIGURA 4.5. Corte transversal dos grânulos com as respectivas dimensões dos pontos de amostragem para MEV. P1 $(10 \mu \mathrm{m}), \mathrm{P} 2(10 \mu \mathrm{m})$ e P3 $(10 \mu \mathrm{m})$

FIGURA 5.1. Variação temporal da carga orgânica volumétrica $\left(\mathrm{COV}_{\text {individual }}\right)$ para as câmaras C1, C2, C3 e C4 no período de operação do reator RAS .54

FIGURA 5.2. Comportamento da carga orgânica volumétrica global ( $\left.\mathrm{COV}_{\text {global }}\right)$ no decorrer do período de operação do reator RAS. 
FIGURA 5.3. Variação temporal da carga orgânica aplicada ao lodo $\left(\mathrm{COAL}_{\text {individual }}\right)$ para as câmaras C1, C2, C3 e C4 no período de operação do reator RAS

FIGURA 5.4. Comportamento da carga orgânica global aplicada ao lodo(COAL global $)$ no decorrer do período de operação do reator RAS.

FIGURA 5.5. Variação temporal da concentração de $\mathrm{DQO}_{\text {bruta }}$ para a vinhaça e o efluente das câmaras C1, C2, C3 e C4. .58

FIGURA 5.6. Variação temporal das eficiências de remoção global de $D_{Q} O_{\text {bruta }}$ do RAS

FIGURA 5.7. Eficiências de remoção individual de $\mathrm{DQO}_{\text {bruta }}$ versus $\mathrm{COV}_{\text {individual }}$ para as câmaras C1, C2, C3 e C4. .59

FIGURA 5.8. Variação temporal da concentração de $\mathrm{DQO}_{\text {filtrada }}$ para a vinhaça e o efluente das câmaras $\mathrm{C} 1, \mathrm{C} 2, \mathrm{C} 3$ e C4

FIGURA 5.9. Variação temporal das eficiências de remoção global de $D Q O_{\text {Filtrada }}$ durante a operação do RAS

FIGURA 5.10. Eficiências de remoção individual de $D O_{\text {Filtrada }}$ versus $C O V$ para as câmaras C1, C2, C3 e C4.

FIGURA 5.11. Variação temporal da concentração de carboidratos para a vinhaça e o efluente das câmaras do RAS.

FIGURA 5.12. Eficiências de remoção individual de carboidratos para as câmaras $\mathrm{C} 1, \mathrm{C} 2$, $\mathrm{C} 3$ e $\mathrm{C} 4$ 
FIGURA 5.13. Variação temporal de alcalinidade total a bicarbonato para a vinhaça e o efluente das câmaras do RAS.

FIGURA 5.14. Valores médios de alcalinidade a bicarbonato para a vinhaça e o efluente das câmaras do RAS

FIGURA 5.15. Variação temporal das concentrações de ácidos voláteis (AVT) para a vinhaça e os efluentes das câmaras do RAS.

FIGURA 5.16. Concentração média de AVT para a vinhaça e o efluente das câmaras do RAS.

FIGURA 5.17. Variação temporal dos valores de pH para a vinhaça e o efluente das câmaras do RAS

FIGURA 5.18. Variação temporal de sólidos suspensos totais (SST), sólidos suspensos fixos (SSF) e sólidos suspensos voláteis (SSV) ao longo da operação do RAS

FIGURA 5.20. Variação temporal da produção de metano para as câmaras $\mathrm{C} 1, \mathrm{C} 2, \mathrm{C} 3$ e C4. .76

FIGURA 5.21. Composição de metano (a) e $\mathrm{CO}_{2}$ (b) presente no biogás obtido para as câmaras do reator RAS.

FIGURA 5.22. Produção acumulada de metano durante o ensaio de AME para o lodo das câmaras do reator RAS. .81

FIGURA 5.23. Morfologias microbianas observadas para o lodo de inóculo e as câmaras do RAS sob microscopia óptica. Inóculo (a), C1 (b), C2 (c), C3 (d) e C4 (e). .84 
FIGURA 5.24. Imagens da MEV obtidas para as amostra do inóculo e das câmaras do reator RAS. Inóculo (A, B e C); C1 (D, E e F); C2 (G, H e I); C3 (J, K e L) e C4 (M, N e O) .86

FIGURA 5.25. Dendograma (UPGMA) obtido a partir do perfil das bandas de DGGE para o Domínio Archaea. .88

FIGURA 5.26. Correlação do Índice de diversidade Shannon e a dominância para o grupo Archaea .89

FIGURA 5.27. Dendograma (UPGMA) obtido a partir do perfil das bandas de DGGE para o Domínio Bacteria. .89

FIGURA 5.28. Correlação do Índice de diversidade Shannon e a dominância para o grupo Bacteria. .90

FIGURA 5.29. Análise filogenética obtida do sequenciamento para o domínio Archaea. .93

FIGURA 5.30. Análise filogenética obtida do sequenciamento para o domínio Bacteria .96

FIGURA 5.31. Valores de COAL aplicadas ao lodo nas Fases I, II e III nos ensaios em regime de batelada. 102

FIGURA 5.32. Valores de carga orgânica obtidas para as Fases I, II e III nos ensaios em regime de batelada. 
FIGURA 5.33. Valores de DQO inicial e final obtida para as quatro câmaras nos ensaios em batelada sequencial. (A) Fase I; (B) Fase II e (C) Fase III

FIGURA 5.34. Eficiências de remoção de DQO versus a COAL aplicada nos ensaios em batelada na Fase I (A), Fase II (B) e Fase III (C). 106

FIGURA 5.35. Valores de concentração de carboidratos inicial e final obtida para as quatro câmaras nos ensaios em batelada sequencial. (A) Fase I; (B) Fase II e (C) Fase III. 110

FIGURA 5.36. Eficiência de remoção de carboidratos para as quatro câmaras nos ensaios em batelada sequencial. Fase I (A), Fase II (B) e Fase III (C) 111

FIGURA 5.37. Valores de $\mathrm{pH}$ inicial e final obtidos para as quatro câmaras nos ensaios em batelada sequencial. (A) Fase I; (B) Fase II e (C) Fase III 113

FIGURA 5.38. Valores de concentração de ácidos graxos voláteis (AGV) obtidos para as quatro câmaras nos ensaios em batelada sequencial. (A) Fase I; (B) Fase II e (C) Fase III. 116

FIGURA 5.39. Produção volumétrica de metano obtida para os reatores operados em batelada. 120

FIGURA 5.40. Composição do biogás obtida para as quatro câmaras nos ensaios em batelada. Fase I (A); Fase II (B) e Fase III (C) 120

FIGURA 5.41. Dendograma (UPGMA) obtido a partir do perfil das bandas de DGGE para o domínio Bacteria após os ensaios em batelada sequencial 124 
FIGURA 5.42. Correlação do Índice de diversidade Shannon e a dominância para o grupo Bacteria obtidos nos ensaios em batelada para a Fase I (a), Fase II (b) e Fase III (c).

FIGURA 5.43. Dendograma (UPGMA) obtido a partir do perfil das bandas de DGGE para o domínio Archaea após os ensaios em batelada sequencial

FIGURA 5.44. Correlação do Índice de diversidade Shannon e a dominância para o grupo Archaea obtidos nos ensaios em batelada para a Fase I (a), Fase II (b) e Fase III (c). 128

FIGURA 5.45. $\mathrm{COV}_{\text {global }}$ versus eficiência de remoção de DQO obtido na operação do reator RAS na Fase I. C1(a), C2 (b), C3(c) e C4 (d). $p$-valor = 0,000006 130

FIGURA 5.46. $\mathrm{COV}_{\text {global }}$ versus eficiência de remoção de DQO obtido na operação do reator RAS na Fase II. C1(a), C2 (b), C3(c) e C4 (d). $p$-valor $=0,005573$

FIGURA 5.47. $\mathrm{COV}_{\text {global }}$ versus eficiência de remoção de DQO obtido na operação do reator RAS na Fase III. C1(a), C2 (b), C3(c) e C4 (d). $p$-valor $=0,044886$. 132

FIGURA 5.48. $\operatorname{COV}_{\text {global }}$ versus produção de metano obtido na operação do reator RAS na Fase I. C1(a), C2 (b), C3(c) e C4 (d). $p$-valor $=0,000060$. 134

FIGURA 5.49. $\mathrm{COV}_{\text {global }}$ versus produção de metano obtido na operação do reator RAS na Fase II. C1(a), C2 (b), C3(c) e C4 (d). $p$-valor = 0,002520 135

FIGURA 5.50. $\mathrm{COV}_{\text {global }}$ versus produção de metano obtido na operação do reator RAS na Fase III. C1(a), C2 (b), C3(c) e C4 (d). $p$-valor = 0,085282 136 
FIGURA 5.51. COAL versus remoção de DQO nos ensaios em batelada. Fase 1 (a), Fase 2 (b) e Fase 3 (c)

FIGURA 5.52. COAL versus produção de metano nos ensaios em batelada. Fase 1 (a), Fase 2 (b) e Fase 3 (c) 140 


\section{Lista de Tabelas}

TABELA 3.1. Características físico-químicas da vinhaça resultante de mostos de melaço, de caldo de cana e de mostos mistos 8

TABELA 3.2. Principais vantagens dos reatores compartimentados e/ou serial .21

TABELA 3.3. Valores de COV aplicadas no processamento anaeróbio da vinhaça. .26

TABELA 4.1. Caracterização da vinhaça de cana de açúcar utilizada .36

TABELA 4.2. Caracterização do lodo de inóculo utilizado na partida do RAC .37

TABELA 4.3. Etapas e fases experimentais empregadas na condução do trabalho. .38

TABELA 4.4. Resumo dos parâmetros obtidos na operação do reator RAS .40

TABELA 4.5. Parâmetros obtidos ao final da operação do RAC (Etapa 1) empregados nos ensaios em batelada.

TABELA 4.6. Composição dos substratos e soluções de macro e micronutrientes utilizadas nos ensaios de AME. . .45

TABELA 4.7. Parâmetros, frequência e métodos analíticos empregados no monitoramento do desempenho do RAS.

TABELA 5.1. Resumo das principais morfologias microbianas observadas pela MEV ....87 
TABELA 5.2. Valor- $p$ obtidos para as câmaras do reator RAC nos testes de

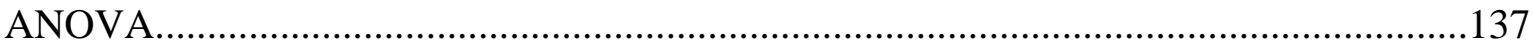

TABELA 5.3. Valores- $p$ obtidos para os reatores operados em batelada sequencial nos testes ANOVA.. 


\section{Lista de Siglas}

ABR - Anaerobic Baffled Reactor

AGV - Ácidos Graxos Voláteis

AME - Atividade Metanogênica Específica

ANOVA - Análise de Variância

ASBR - Reator Anaeróbio Operado em Batelada Sequencial

BRS - Bactérias Redutoras de Sulfato

COV - Carga Orgânica Volumétrica

COAL - Carga Orgânica Aplicada ao Lodo

DGGE - Eletroforese em Gel de Gradiente Desnaturante

DNA - Ácido Dessoxxiribonucléico

DBO - Demanda Bioquímica de Oxigênio

DQO - Demanda Química de Oxigênio

MEV - Microscopia Eletrônica de Varredura

PCR - Reação em Cadeia da Polimerase

pH - Potencial Hidrogeniônico

RAC - Reator Anaeróbio Compartimentado ou Chicanado

RAS - Reator Anaeróbio Serial

SS - Sólidos Suspensos

SF - Sólidos Fixos 
SV - Sólidos Voláteis

ST - Sólidos Totais

SST - Sólidos Suspensos Totais

SSF - Sólidos Suspensos Fixos

SSV - Sólidos Suspensos Voláteis

STV - Sólidos Totais Voláteis

TDH - Tempo de Detenção Hidráulica

UASB - Reator de Fluxo Ascendente com Manta de Lodo 


\section{Lista de Abreviaturas}

$\mathrm{COV}_{\text {global }}$ - Carga Orgânica Volumétrica Global

$\mathrm{COV}_{\text {individual }}$ - Carga Orgânica Volumétrica Individual

COAL global - Carga Orgânica Aplicada ao Lodo Global

$\mathrm{COAL}_{\text {individual }}$ - Carga Orgânica Aplicada ao Lodo Individual

C 1 - Câmara ou compartimento 1 (um)

C 2 - Câmara ou compartimento 2 (dois)

C 3 - Câmara ou compartimento 3 (três)

C 4 - Câmara ou compartimento 4 (quatro) 


\section{SUMÁRIO}

RESUMO

ABSTRACT .ii

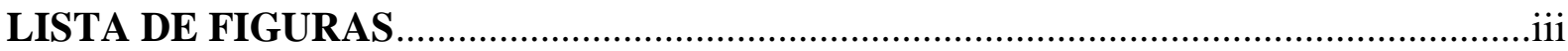

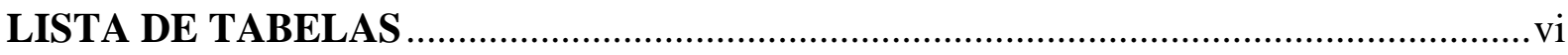

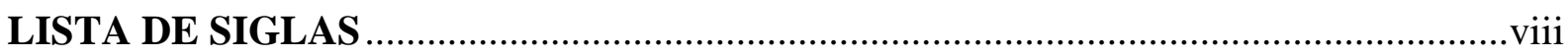

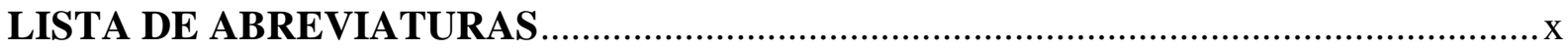

1. INTRODUÇÃ

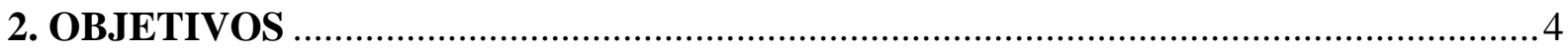

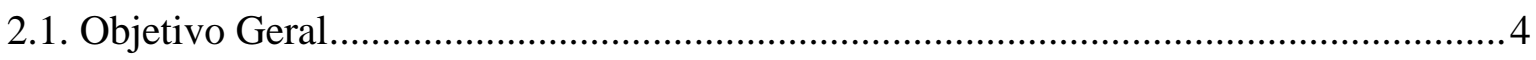

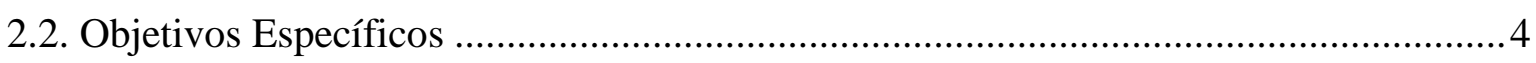

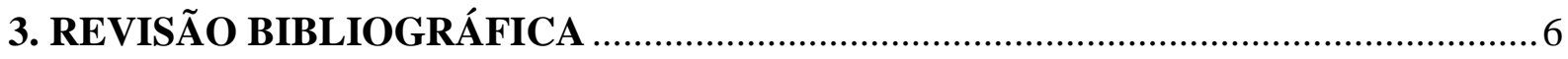

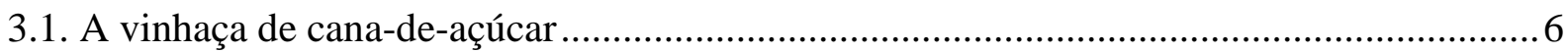

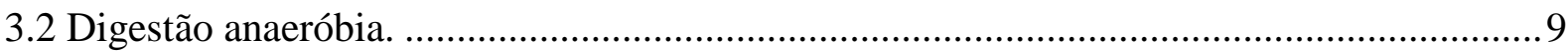

3.2.1. Aspectos bioquímicos e microbiológicos da digestão anaeróbia............................... 10

3.3. Tecnologia anaeróbia aplicada ao processamento da vinhaça...........................................15

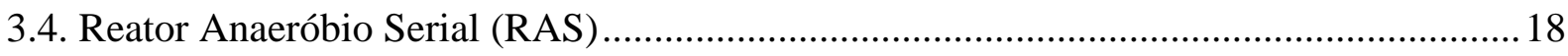

3.5. Desafios no processamento anaeróbio da vinhaça ............................................................22

3.5.1. Carga orgânica aplicada à reatores anaeróbios de alta taxa..........................................23

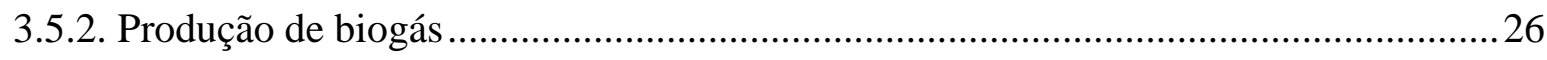

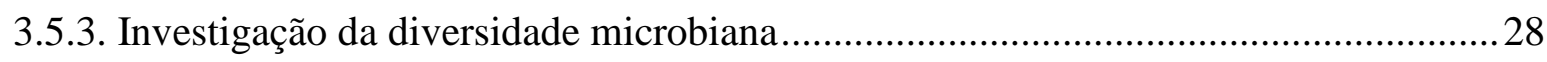

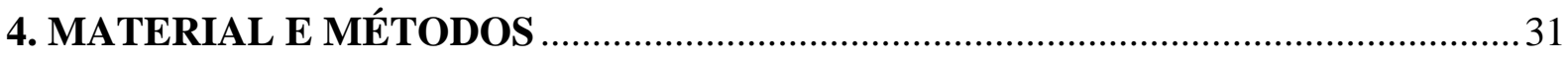

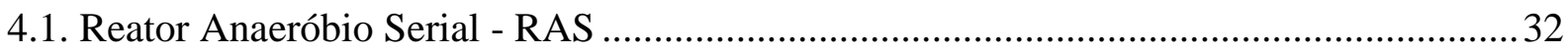

4.2. Reatores Anaeróbio em Batelada Sequencial - ASBR …………………………………....34 


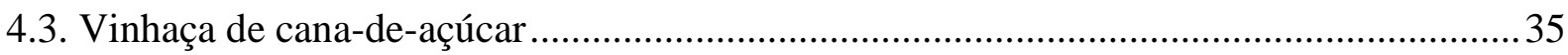

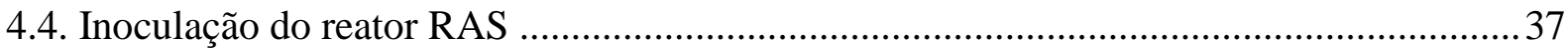

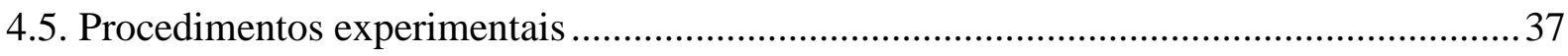

4.5.1. Etapa 1 - Operação e monitoramento do RAC em sistema contínuo ...........................38

4.5.2. Etapa 2 - Operação e monitoramento do ASBR em sistema descontínuo...................41

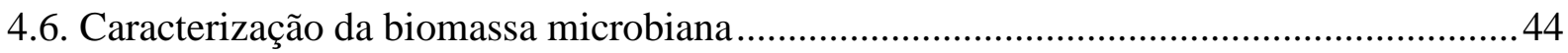

4.6.1 Atividade Metanogênica Específica (AME) ......................................................... 44

4.6.2. Produção de metano e composição do biogás ........................................................... 45

4.6.3. Caracterização microbiana por microscopia e MEV .............................................48

4.6.4. Caracterização da diversidade microbiana por técnica de biologia molecular ..........49

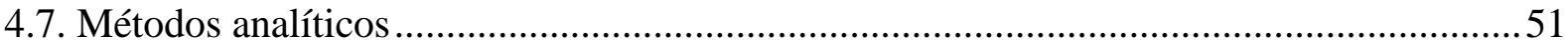

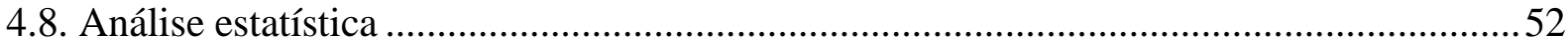

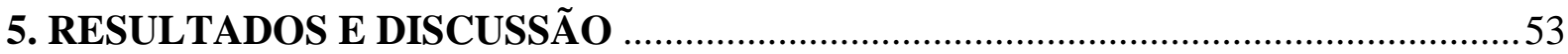

5.1. ETAPA 1 - OPERAÇÃO DO REATOR RAS EM SISTEMA CONTÍNUO ....................53

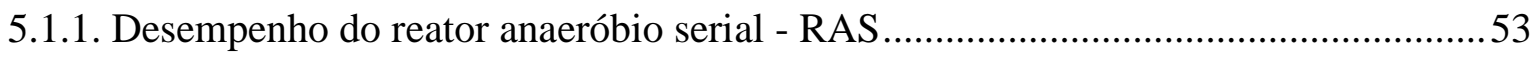

5.1.2. Potencial de produção de metano e composição do biogás........................................76

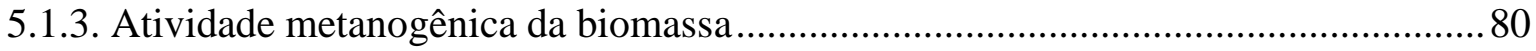

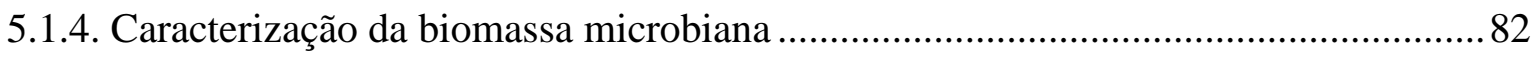

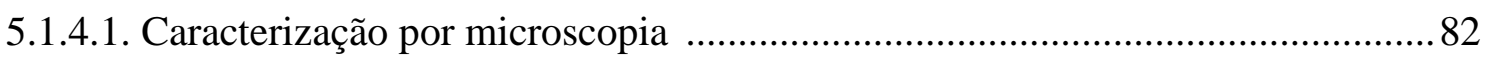

5.1.4.2. Caracterização por técnicas de biologia molecular ....................................... 88

5.1.4.3. Análise filogenética das amostras do reator RAS .........................................92

5.2. ETAPA 2 - OPERAÇÃO DOS REATORES ASBR EM BATELADA......................... 101

5.2.1. Desempenho dos reatores em batelada sequencial ............................................. 101

5.2.2. Produção de metano e composição do biogás ........................................................ 119

5.2.3. Diversidade da comunidade microbiana dos reatores ASBR ................................ 123 
5.3. ANÁLISE ESTATÍSTICA

5.3.1. Etapa 1: Operação contínua do reator RAC 130

5.3.2. Etapa 2: Operação dos reatores ASBR em batelada 138

6. CONCLUSÕES. 142

7. SUGESTÕES PARA TRABALHOS FUTUROS 147

8. REFERÊNCIAS BIBLIOGRÁFICAS 148 



\section{InTRODUÇÃo}

Na etapa de destilação industrial voltada a produção do etanol é produzido um grande volume de vinhaça, principal subproduto da indústria sucroalcoleira. Esta água residuária, é caracterizada por apresentar elevados teores de matéria orgânica e nutrientes tais como nitrogênio, fósforo e potássio, características que permitem seu emprego na fertirrigação de solos agrícolas, reduzindo o uso de adubos químicos.

Dentro deste contexto, verifica-se que, com o estabelecimento de normas e resoluções ambientais cada vez mais restritivas, torna-se de fundamental importância o adequado processamento da vinhaça de cana-de-açúcar visando não apenas seu descarte final como fertilizante, mas também em contrapartida, o seu aproveitamento energético por meio da produção de biogás.

Devido à sua carga orgânica elevada em termos de demanda química de oxigênio (DQO) a vinhaça de cana-de-açúcar representa um insumo para a geração de energia por meio da utilização do biogás que pode ser produzido por tratamentos anaeróbios. Esse potencial chega a representar em termos energéticos, um adicional de $22 \%$ em relação à energia obtida pela combustão do etanol produzido.

Entre as alternativas tecnológicas atuais empregadas no tratamento da vinhaça, destacam-se os processos de digestão anaeróbia, por meio da utilização de diferentes configurações de reatores, tais como, fluxo ascendente e manta de lodo, leito fluidizado, leito fixo e reatores híbridos, entre outros. Em particular, os reatores anaeróbios de alta taxa tipo UASB, tem sido empregados no processamento da vinhaça para redução da elevada carga orgânica e produção de biogás. 
Outra configuração de reator que merece destaque no tratamento de águas residuárias, é o reator anaeróbio serial (RAS), também denominado na literatura inglesa por reator ABR (Anaerobic Baffled Reactor) ou ainda, reator compartimentado e/ou de chicanas (RAC), inicialmente concebido para o tratamento de esgotamento sanitário.

Esta configuração de reator combina as vantagens do filtro anaeróbio, que apresenta alta estabilidade e segurança, e do reator de fluxo ascendente com manta de lodo (UASB), no qual, a própria biomassa agregada facilita a sua retenção no reator, mostrando excelente desempenho para tratamento de águas residuárias com elevada carga orgânica (Boopathy, 1998).

Em termos de processo, o reator compartimentado tipo RAC possibilita a separação de algumas das fases da digestão anaeróbia, o que termodinamicamente favorece a formação de gás metano, liberando o hidrogênio nas primeiras câmaras (Barber e Stuckey, 1999).

No entanto, ainda são necessários estudos fundamentais para o entendimento dos sistemas de digestão anaeróbia da vinhaça visando estabilidade operacional do processo e a otimização do projeto de reatores de alta taxa compactos e eficientes na degradação da matéria orgânica em biogás, permitindo no futuro sua aplicação em escala aumentada.

Entre os principais fatores que necessitam ser mais bem elucidados para o entendimento do processamento da vinhaça de cana de açúcar pode-se citar: a influência da carga orgânica volumétrica (COV) e carga orgânica aplicada ao lodo (COAL); produção e composição do biogás em cada uma das câmaras (compartimentos); e a dinâmica dos consórcios microbianos envolvidos na produção de biogás.

No que se refere ao processamento da vinhaça por meio de reatores do tipo serial (RAS), verifica-se uma escassez de trabalhos na literatura científica, necessitando dessa 
forma, estudos direcionados à investigação do seu potencial de aplicação, estudando-se a influência dos fatores supracitados.

A partir do exposto, este trabalho visou testar a hipótese de que a compartimentação serial aplicada ao processamento anaeróbio da vinhaça trará vantagens, como a melhoria da degradação da matéria orgânica na produção de biogás. Espera-se essa vantagem, uma vez que o reator serial separa as fases da digestão anaeróbia em regiões nas quais, em princípio, predominam os microrganismos mais adaptados para cada uma das etapas da biodigestão. 


\section{Oв हEтTOS}

\subsection{Objetivo Geral}

O objetivo principal deste trabalho foi investigar o emprego de reator anaeróbio serial (RAS) no processamento de vinhaça de cana-de-açúcar, visando à remoção de matéria orgânica e produção de biogás.

\subsection{Objetivos Específicos}

Os objetivos específicos do trabalho foram:

- Verificar a influência das condições operacionais sobre a atividade metanogênica específica (AME) da biomassa presente em cada compartimento do reator.

- Avaliar a diversidade da comunidade microbiana envolvida no processamento da vinhaça em cada compartimento do reator por meio de exames microscópicos, análise de biologia molecular e sequenciamento.

- Correlacionar a diversidade microbiana com os parâmetros de desempenho e operação do reator na produção de biogás.

- Estudar em reator de batelada o efeito da imposição de taxas de carregamento orgânico, simulando a operação contínua do reator anaeróbio serial. 
- Avaliar a influência do carregamento orgânico na eficiência operacional do reator serial em sistema contínuo e descontínuo, em termos de remoção de matéria orgânica e produção de metano. 


\section{Revisão Biblografica}

\subsection{A vinhaça de cana-de-açúcar}

O processamento industrial da cana-de-açúcar resulta na geração de grande quantidade de diferentes resíduos tais como, bagaço, cinzas, material particulado, vinhaça, entre outros resíduos líquidos. A maioria desses resíduos possui alto teor de matéria orgânica, que quando tratados adequadamente, podem ser utilizados como fonte de energia.

Após a destilação do álcool combustível utilizando cana-de-açúcar como matéria prima, verifica-se a geração da vinhaça, resíduo líquido também conhecido por diferentes denominações, tais como, vinhoto, garapão, restilo, caldo ou água residuária de destilaria. Este efluente é rico em material orgânico, apresenta baixos valores de $\mathrm{pH}$, além de possuir nutrientes importantes como o nitrogênio, fósforo e potássio, características na qual é muito utilizada para a prática de fertirrigação do solo, reduzindo o uso de adubos químicos (Cruz et al., 2007).

As características da vinhaça dependem principalmente da matéria prima utilizada para a produção do álcool. Vinhaças de cana-de-açúcar com altas concentrações de sólidos solúveis podem ser obtidas quando o açúcar constitui a matéria prima na produção.

A composição química da vinhaça é bastante variável dependendo principalmente, de fatores como a natureza e a composição da matéria prima, do sistema usado no preparo do mosto, do método de fermentação adotado, do sistema de condução da 
fermentação alcoólica, da espécie de levedura utilizada, do tipo de aparelho de destilação empregado, dentre outros (Glória e Orlando Filho, 1984).

O constituinte principal da vinhaça é a matéria orgânica, basicamente sob a forma

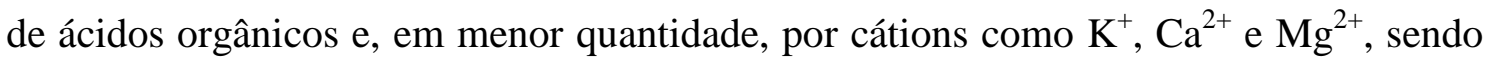
que sua riqueza nutricional está ligada à origem do mosto (Rossetto, 1987).

Outras características importantes da vinhaça de cana-de-açúcar são a cor, a presença de metais pesados e de poluentes orgânicos tais como clorofórmio, pentaclorofenol, fenol e cloreto de metileno, sendo que estes podem impor caráter inibidor em sistemas de tratamento de efluentes líquidos por processos biológicos (Wilkie et al., 2000).

A vinhaça é um subproduto que pode ser resultante de três processos distintos na usina: tem-se o vinhoto de mosto de melaço, como subproduto da produção de açúcar; o vinhoto de mosto de caldo produzido pela fermentação alcoólica do caldo e o vinhoto misto, gerado pela mistura de caldo e melaço.

Na Tabela 3.1 são apresentadas as características de algumas vinhaças de cana-deaçúcar a partir do melaço, do caldo e da mistura de ambos. 
Tabela 3.1 - Características físico-químicas da vinhaça resultante de mostos de melaço, de caldo de cana e de mostos mistos.

\begin{tabular}{|c|c|c|c|}
\hline Parâmetro & Melaço & Caldo & Misto \\
\hline$\overline{\mathrm{pH}}$ & $4,2-5,0$ & $3,7-4,6$ & $4,4-4,6$ \\
\hline Temperatura $\left({ }^{\circ} \mathrm{C}\right)$ & $80-100$ & $80-100$ & $80-100$ \\
\hline $\mathrm{DBO}(\mathrm{mg} / \mathrm{L})$ & 25000 & $6000-16500$ & 19800 \\
\hline DQO (mg/L) & 65000 & $15000-33000$ & 45000 \\
\hline Sólidos totais (mg/L) & 81500 & 23700 & 52700 \\
\hline Sólidos voláteis (mg/L) & 60000 & 20000 & 40000 \\
\hline Sólidos fixos (mg/L) & 21500 & 3700 & 12700 \\
\hline Nitrogênio (mg.N/L) & $450-1600$ & $150-700$ & $480-710$ \\
\hline Fósforo (mg.P $\left.{ }_{2} \mathrm{O}_{5} / \mathrm{L}\right)$ & $100-290$ & $10-210$ & $9-200$ \\
\hline Potássio (mg. $\left.\mathrm{K}_{2} \mathrm{O} / \mathrm{L}\right)$ & $3740-7830$ & $1200-2100$ & $3340-4600$ \\
\hline Cálcio (mg.CaO/L) & $450-5180$ & $130-1540$ & $1330-4570$ \\
\hline Magnésio (mg.MgO/L) & $420-1520$ & $200-490$ & $580-700$ \\
\hline Sulfato $\left(\mathrm{mg} \cdot \mathrm{SO}_{4}{ }^{-} / \mathrm{L}\right)$ & 6400 & $600-760$ & $3700-3730$ \\
\hline Carbono (mg.C/L) & $11200-22900$ & $5700-13400$ & $8700-12100$ \\
\hline Relação C/N & $16-16,27$ & $19,7-21,07$ & $16,4-16,43$ \\
\hline Matéria orgânica (mg/L) & 63400 & 19500 & 38000 \\
\hline
\end{tabular}

Fonte: Pinto (1999).

Considerando a carga orgânica da vinhaça, conclui-se que ela é aproximadamente cerca de cem vezes aquela encontrada em esgotos sanitários classificados como fracos, médios e fortes, com proporção média de geração de 9,0 a 14,0 L para cada litro de álcool produzido (Cabello et al., 2009).

Neste contexto, verifica-se que, com o estabelecimento de normas e resoluções ambientais cada vez mais restritivas, torna-se de fundamental importância o adequado processamento da vinhaça de cana-de-açúcar visando não apenas o seu tratamento para o descarte final, mas também em contrapartida, o aproveitamento energético por meio da produção de biogás. 


\subsection{Digestão anaeróbia}

Na década de 1970 várias configurações de reatores anaeróbios de alta taxa foram desenvolvidas, especialmente para o tratamento de águas residuárias industriais, como os reatores de leito fluidizado e o de fluxo ascendente com manta de lodo - UASB (Foresti et al., 1999). No Brasil, o interesse em aplicar a tecnologia da biodigestão anaeróbia foi despertado pela crise energética na década de 70 , aumentando a procura por energias alternativas (Hobson e Wheatley, 1993).

Atualmente, a digestão anaeróbia é considerada uma importante alternativa tecnológica para o tratamento de diferentes tipos de resíduos com elevadas concentrações de material orgânico, devido aos baixos custos operacional e alternativa em substituição de combustíveis fósseis, minimizando a emissão de gases responsáveis pelo efeito estufa (Ticm, 2007).

Durante a digestão anaeróbia, através de diferentes tipos de microrganismos, os compostos orgânicos complexos (carboidratos, proteínas e lipídios) do efluente são convertidos em produtos mais simples como o dióxido de carbono $\left(\mathrm{CO}_{2}\right)$ e metano $\left(\mathrm{CH}_{4}\right)$ na ausência de oxigênio molecular (Foresti et al., 1999).

O tratamento biológico anaeróbio é um processo microbiológico complexo que implica no trabalho sintrófico de diversos grupos de bactérias. O desempenho da digestão é ditado pelo equilíbrio relativo entre as principais populações viáveis de bactérias. Assim, a compreensão fundamental do processo implica o crescimento dos vários tipos de bactérias anaeróbias e facultativas (Parkin e Owen, 1986).

Entre os principais fatores determinantes que governam o crescimento bacteriano na digestão anaeróbia estão: tempo de retenção celular (TRC); mistura adequada (contato substrato-microrganismo); $\mathrm{pH}$ adequado; controle de temperatura; 
concentrações adequadas de nutrientes; ausência (ou assimilação) de materiais tóxicos; e características de alimentação adequadas.

\subsubsection{Aspectos bioquímicos e microbiológicos da digestão anaeróbia}

O processo de digestão anaeróbia envolve a degradação e estabilização química da matéria orgânica levando à formação de gases tais como $\mathrm{CO}_{2}(\mathrm{~g})$ e $\mathrm{CH}_{4}$ (g), além de produtos inorgânicos e biomassa, como simplificado pela Equação 1.

Matéria orgânica $\longrightarrow \mathrm{CH}_{4}+\mathrm{CO}_{2}+$ biomassa $+\mathrm{NH}_{3}+\mathrm{H}_{2} \mathrm{~S}+$ calor (Eq. 1)

Parte dos produtos da degradação anaeróbia é constituída por gases; estes se desprendem da água residuária, formando uma fase gasosa, o biogás. Dessa forma, há remoção do material orgânico na fase líquida por meio da sua transferência de massa para a fase gasosa, embora o material orgânico não seja mineralizado como no caso do catabolismo oxidativo (Foresti et al., 1999).

A digestão anaeróbia é considerada um processo bioquímico complexo, composto por várias reações sequenciais, cada uma com sua população de microrganismos específicos. Na Figura 3.1, é apresentada uma representação esquemática dos passos metabólicos e grupos microbianos envolvidos no processo de biodigestão anaeróbia. 


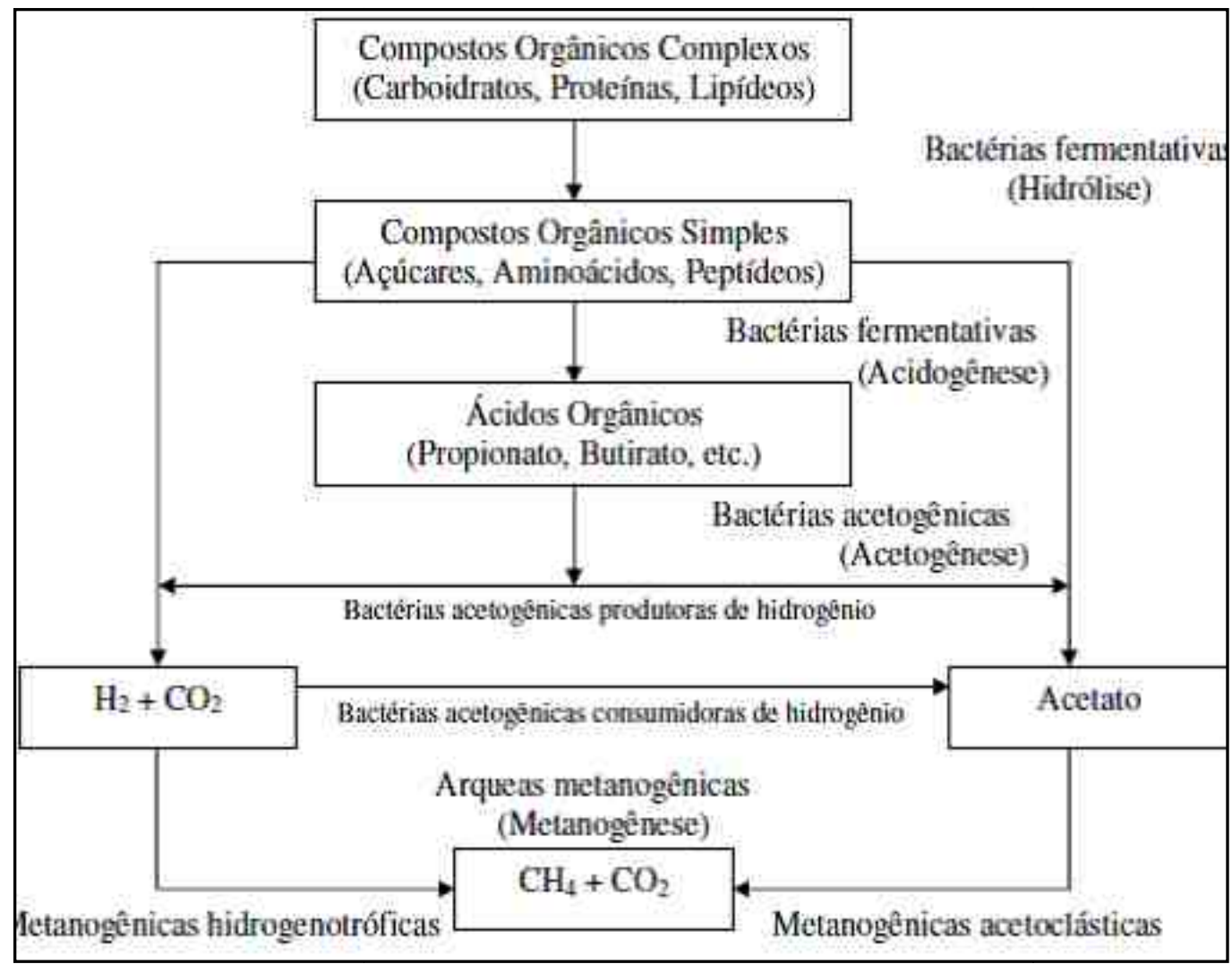

Figura 3.1 - Sequencias metabólicas e grupos microbianos envolvidos no processo de biodigestão anaeróbia (Fonte: Adaptado de Speece, 1996).

As populações bacterianas que constituem o lodo anaeróbio desenvolvem os processos de digestão por fases, (hidrolítica, ácida e metanogênica), tornando o material orgânico mais complexo (carboidratos, proteínas e lipídios) em material de menor peso molecular até a formação do metano e gás carbônico. Para cada fase existem grupos de organismos específicos que atuam em reações específicas.

As principais etapas que compreendem o processo global da digestão anaeróbia e descritas a seguir são: hidrólise, acidogênese, acetogênese e metanogêse.

\section{Hidrólise}


A primeira fase do processo de digestão anaeróbia consiste na hidrólise de materiais particulados complexos (polímeros), transformando-os em materiais mais simples, os quais podem atravessar as paredes celulares das bactérias fermentativas, visto que as mesmas não são capazes de assimilar o material particulado. A conversão dos compostos ocorre através de exoenzimas excretadas pelas bactérias fermentativas.

Bactérias anaeróbias facultativas ou obrigatórias são os microrganismos responsáveis pela hidrólise e fermentação. Organismos isolados de reatores anaeróbios incluem Clostridium sp., Peptococcusanaerobus sp., Bifidobacterium sp., Desulphovibrio sp., Corynebacterium sp., Lactobacillus, Actinomyces, Staphylococcus, e Escherichia coli (Metcalf e Eddy, 2003).

\section{Acidogênese}

Os compostos dissolvidos na etapa da hidrólise são então assimilados pelas células das bactérias fermentativas e, após a acidogênese, excretados como substâncias orgânicas simples como os ácidos graxos voláteis (AGV), alcoóis, ácido lático e compostos minerais tais como $\mathrm{CO}_{2}, \mathrm{H}_{2}, \mathrm{NH}_{3}, \mathrm{H}_{2} \mathrm{~S}$, entre outros (Van Haandel e Lettinga, 1994).

De acordo com Van Haandel e Lettinga (1994) entre as bactérias envolvidas na acidogênese são encontradas espécies anaeróbias estritas e facultativas, sendo que estas últimas são importantes na reação de consumo do oxigênio dissolvido presentes no material em fermentação anaeróbia, que poderia afetar negativamente o processo (poderia se tornar uma substância tóxica para as arqueias metanogênicas se não fosse removido pelas bactérias acidogênicas facultativas). 


\section{Acetogênese}

$\mathrm{Na}$ acetogênese ocorre a conversão dos produtos da acidogênese pelas bactérias sintróficas acetogênicas, que são responsáveis pela oxidação de compostos intermediários, como propionato e butirato, em substrato apropriado para os organismos metanogênicos, como o acetato, hidrogênio e dióxido de carbono.

As bactérias acetogênicas convertem cerca de $60 \%$ a $70 \%$ da demanda química de oxigênio (DQO) original em ácido acético (Chernicharo, 2007). Durante a formação dos ácidos acético e propiônico, uma grande quantidade de íon hidrogênio é formada, reduzindo o valor do $\mathrm{pH}$ no meio aquoso.

Para a manutenção de baixas pressões parciais de $\mathrm{H}_{2}$, as bactérias acetogênicas estabelecem uma estreita relação de sintrofia com os microrganismos utilizadores de $\mathrm{H}_{2}$, sejam eles arqueias metanogênicas hidrogenotróficas ou bactérias redutoras de sulfato (Foresti et al., 1999).

Segundo Vazoller (2013), as principais espécies de microrganismos envolvidos nesta etapa são: Syntrophomonaswolinii, S. wolfei, Syntrophusbuswellii, Clostridium bryantii, Acetobacteriumwoddii.

\section{Metanogênese}

A última fase da conversão da matéria orgânica é realizada pelas arqueias metanogênicas anaeróbias obrigatórias, sendo que são microrganismos que possuem baixo crescimento e são mais sensíveis aos fatores ambientais tais como temperatura, pH e material tóxico, entre outros (Cammarota, 2010). 
Segundo Parkin e Owen (1986) em função de sua fisiologia as arqueias metanogênicas são divididas em dois grupos: arqueias utilizadoras de acetato (acetoclásticas) e arqueias utilizadoras de hidrogênio (hidrogenotróficas).

Na metanogênese acetoclástica o acetato é o principal precursor do metano, pois cerca de $70 \%$ do metano produzido no reator é derivado da descarboxilação deste ácido. Como principais grupos de arqueias metanogênicas podem ser citados os gêneros Methanosaeta e Methanosarcina (Parkin e Owen, 1986).

Já na metanogênese hidrogenotrófica, o metano proveniente da redução do dióxido de carbono com o hidrogênio correspondente a 30\% do total produzido em um reator. Ao contrário das acetoclásticas, praticamente todas as espécies conhecidas de arqueias metanogênicas são capazes de produzir metano a partir do hidrogênio e gás carbônico, com destaque para os gêneros Methanobacterium, Methanobrevibacter, Methanospirillum, Methanoculleus e Methanocorpusculum (Leclerc et al., 2004).

As arqueias metanogênicas são mais sensíveis ao acúmulo de ácidos graxos voláteis $(\mathrm{AGV})$ e hidrogênio do que a bactérias acidogênicas. $\mathrm{O} \mathrm{pH}$ ótimo para as bactérias acidogênicas é entre 5,5 a 6,0 e para as metanogênicas entre 6,8 a 7,2. Se a taxa de hidrólise é mais alta que a metanogênica e a alcalinidade do sistema não é suficientemente elevada, pode ocorrer acúmulo de AGV e hidrogênio e consequentemente acidificação do reator conduzindo à falha no processo (Metcalf e Eddy, 2003).

A etapa da metanogênese é considerada limitante de todo o processo de estabilização, devido à baixa taxa de crescimento das arqueias metanogênicas. Desta forma, torna-se importante que sejam oferecidas ao meio as condições ideais para o desenvolvimento harmônico dessa população. 


\subsection{Tecnologia anaeróbia aplicada ao processamento da vinhaça}

Inúmeras alternativas de tratamento para estes efluentes já foram reportadas na literatura. Vale destacar que, em escala real, dificilmente uma unidade isolada cumprirá os restritos níveis de descarga exigidos pelas legislações, sendo necessário o desenvolvimento de sistemas geralmente integrando várias unidades.

Estudos direcionados para o desenvolvimento de alternativas tecnológicas, visando à redução de áreas fertirrigadas, a recuperação da água e o aproveitamento energético da vinhaça de cana-de-açúcar, estão sendo fomentadas pelas usinas e por agências de pesquisas governamentais brasileiras (Van Haandel, 2005).

Entre as principais alternativas tecnológicas atuais empregadas no tratamento da vinhaça, tem-se destacado os processos anaeróbios, principalmente por meio da aplicação de reatores de fluxo ascendente com manta de lodo, reatores de leito fluidizado, reatores de leito fixo e reatores híbridos.

Uma das principais vantagens do processamento anaeróbio da vinhaça de cana de açúcar além da redução da carga orgânica poluidora é a produção do biogás (metano), com a possibilidade de aproveitamento como fonte energética.

A digestão anaeróbia da vinhaça tem despertado grande interesse entre pesquisadores do mundo todo devido aos sucessos já alcançados, ao interesse científico no aprimoramento do processo de degradação deste efluente industrial de alta carga orgânica e inorgânica e, principalmente, devido ao elevado potencial de produção de energia alternativa (Van Haandel, 2005).

O sucesso no processamento anaeróbio da vinhaça está profundamente associado aos aspectos ambientais encontrados nos reatores devido às características físico- 
químicas favoráveis ao desenvolvimento das populações metanogênicas (Van Haandel, 2005).

Um dos fatores que influenciam diretamente o processo anaeróbio é a temperatura do meio. Estudo comparativo da digestão anaeróbia da vinhaça em reator anaeróbio nas faixas mesofílica e termofílica realizado por Ribas (2006), indicou melhor desempenho do reator na faixa mesofílica.

Em virtude da elevada temperatura da vinhaça observada ao sair da coluna de destilação (acima de $80{ }^{\circ} \mathrm{C}$ ), deve ser adotado sistema de redução de temperatura anteriormente à submissão ao processamento anaeróbio mesofílico.

Outros fatores como alcalinidade, ácidos voláteis e pH estão relacionados entre si e influenciam igualmente a digestão anaeróbia. O tamponamento do meio na degradação da vinhaça é um fator importante para adequar o pH (entre 6,6 e 7,4) e neutralizar os ácidos formados no processo. Embora a digestão anaeróbia gere alcalinidade na conversão de ácidos voláteis intermediários com geração de cátion como produto final (bicarbonato de sódio ou bicarbonato de amônia), a adição de álcali é extremamente recomendada para a digestão anaeróbia com alta taxa de carboidratos (Chernicharo, 2007).

Neste sentido, diversos trabalhos têm investigado o processamento anaeróbio da vinhaça de cana de açúcar por meio de diferentes configurações de reatores obtendo resultados parcialmente satisfatórios, tais como, Gonzalez et al., (1998); Pinto (1999); Bermúdez-Savón et al. (2000); Nandy et al., (2002); Fernandez et al. (2008); Satyawali e Balakrishnan (2008); Cabello et al. (2009); Rocha (2012); Brown (2012), entre outros, verificando-se assim, o interesse e importância desse processo de tratamento.

Gonzalez et al., (1998) investigaram a granulação de lodo anaeróbio na degradação de vinhaça diluída da produção de álcool de cana de açúcar por meio de 
reator UASB de 16,5 L, concentrações de DQO afluente de 3.700 a 3.800 mg.L ${ }^{-1}$ e COV de 2,3 a 7,1 g DQO L ${ }^{-1} \cdot \mathrm{d}^{-1}$, obtendo remoção de DQO de 78,8\% com COV de 7,1 DQO $\mathrm{L}^{-1} \cdot \mathrm{d}^{-1}$ e máxima de metano em 6,0 g DQO L $\mathrm{L}^{-1} \cdot \mathrm{d}^{-1}$, obtendo resultados satisfatórios na granulação do lodo.

Bermúdez-Savón et al. (2000) avaliaram o efeito da utilização de soda cáustica e cal como agentes tamponantes na degradação anaeróbia de vinhaça, bem como a sua complementação com nutrientes nitrogenados e fosfatados. Os resultados apontaram que a prévia neutralização da vinhaça favoreceu a manutenção do $\mathrm{pH}$ adequado ao processo de digestão, sendo que, a adição de nutrientes nas condições estudadas não apresentou influência na digestão anaeróbia.

Nandy et al. (2002) estudaram o tratamento anaeróbio da vinhaça sem diluição proveniente da produção de álcool de cana de açúcar em reator anaeróbio de filme fixo com capacidade de $4500 \mathrm{~m}^{3}$, DQO afluente de $40.000 \mathrm{mg} \cdot \mathrm{L}^{-1}$, COV de 5,0 kg DQO m ${ }^{3} \cdot \mathrm{d}^{-1}$ e TDH de 9 dias, obtendo remoções de DQO de 68,8\% a 70,4\% e composição de $62 \%$ de metano.

No estudo realizado por Fernandez et al. (2008), os pesquisadores investigaram a influência da COV na degradação da vinhaça em reator de leito fluidizado utilizando zeólita natural como meio suporte em escala de laboratório, DQO afluente de 63.000 mg.L ${ }^{-1}$, COV variando de 3 a 20 g DQO L ${ }^{-1} \cdot \mathrm{d}^{-1}$ e TDH de aproximadamente 11 horas. Os resultados demonstraram remoção de DQO superior a $80 \%$ com o aumento da COV de 3 a 20 g DQO L ${ }^{-1} \cdot d^{-1}$.

Satyawali e Balakrishnan (2008) apresentaram estudos com aplicação de reatores UASB no tratamento de vinhaça obtendo resultados de remoção de DQO entre 90 a $75 \%$ com COV de 15 a $24 \mathrm{~kg}$ DQO $\mathrm{m}^{-3} \cdot \mathrm{d}^{-1}$, respectivamente. 
Rocha (2012) comparou o desempenho de dois reatores anaeróbios híbridos com biomassa imobilizada (RAHBI) em escala de bancada, no processamento de vinhaça, onde um reator (I) era alimentado com vinhaça sem tratamento prévio, e o outro reator (II) com vinhaça previamente submetida à coagulação com polímero a base de cálcio, obtendo remoção de matéria orgânica em termos de DQO de 77,5\% e 79,7\%, para os reatores I e II, respectivamente.

Brown (2012) avaliou o comportamento da biomassa de um reator UASB de $20 \mathrm{~L}$ utilizado no processamento de vinhaça de destilaria de álcool, aplicando-se uma DQO de 1071 a $20748 \mathrm{mg} \cdot \mathrm{L}^{-1}$, COV de 0,53 a 4,5 $\mathrm{kg}$ DQO $\mathrm{m}^{-3} \cdot \mathrm{d}^{-1}$ e recirculação do efluente final, obtendo eficiência média na remoção de DQO entre $86 \%$ a $96 \%$, e bons resultados na produção de biogás.

A partir dos estudos mencionados anteriormente, verifica-se a obtenção de bons resultados por meio dos sistemas de digestão anaeróbia no processamento de vinhaça de cana de açúcar, na redução da carga orgânica e consequente aumento da produção de biogás.

\subsection{Reator Anaeróbio Compartimentado - RAC}

O reator anaeróbio compartimentado (RAC), também denominado na literatura inglesa como reator ABR (Anaerobic Baffled Reactor) ou ainda reator de chicanas, foi desenvolvido inicialmente por pesquisadores da Universidade de Stanford na década de 1980 (McCarty, 1981).

Ao contrário dos reatores com manta de lodo (UASB), o reator RAC foi

inicialmente concebido e amplamente aplicado para o tratamento do esgotamento 
sanitário, sendo posteriormente empregado no processamento de outros tipos de águas residuárias.

O RAC é similar no projeto e aplicação ao reator UASB, porém sem o requerimento da formação de grânulos para seu funcionamento (Bachmann et al., 1985). O projeto do reator é simples, sem peças móveis ou mistura mecânica, tornando seu custo de construção relativamente barato; não há exigências para as propriedades da biomassa dentro do reator; a geração de lodo é baixa e o tempo de retenção de sólidos é elevado; não a necessidade de fixação da biomassa em material suporte ou uma câmara de sedimentação de sólidos (Foxon et al., 2004).

Na Figura 3.2 é apresentado o desenho esquemático simplificado da configuração de um reator anaeróbio compartimentado para o tratamento de águas residuárias.

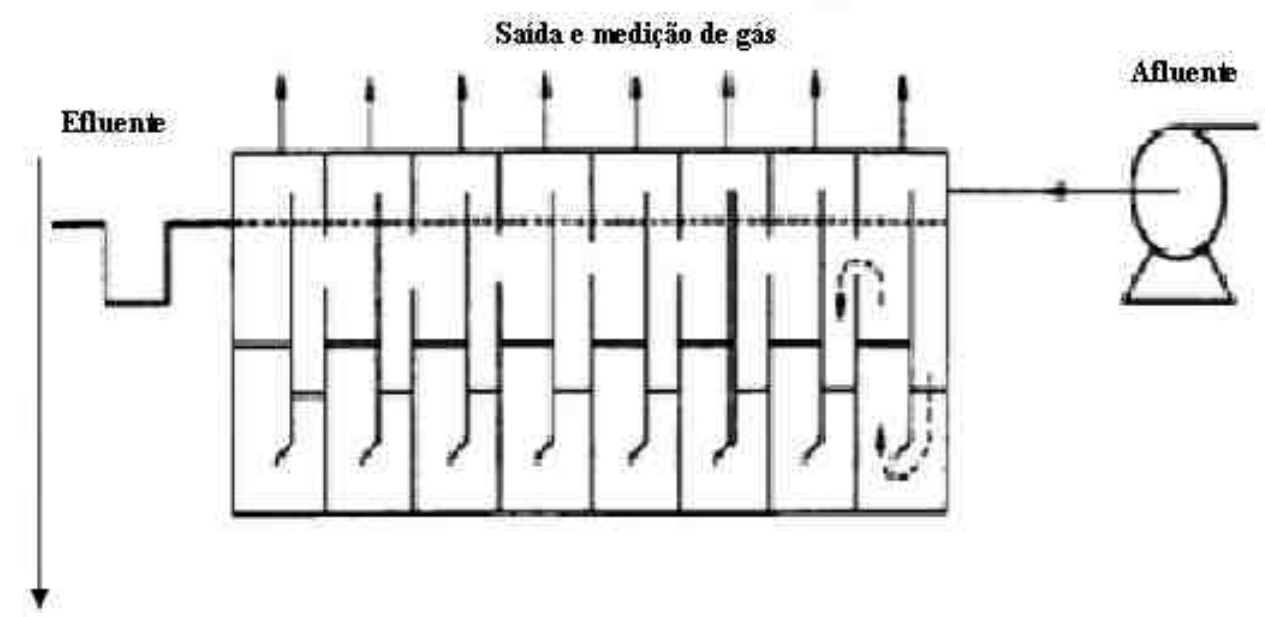

Figura 3.2 - Desenho esquemático de um reator anaeróbio compartimentado. Fonte: Adaptado de Grobickj e Stuckey (1992).

O reator compartimentado é conhecido por constituir de um tanque com diversas câmaras dispostas horizontalmente em série, cada qual separada por paredes ou chicanas verticais. O fluxo de esgoto em cada câmara é vertical ascendente, sendo que a 
alimentação sucessiva de cada câmara ocorre pelo efluente da anterior por meio de dispositivos, em geral, tubulações (Kato et al., 2001).

De maneira semelhante, o reator anaeróbio serial é composto por câmaras (compartimentos) dispostas verticalmente em série, sendo o fluxo de escoamento ascendente de uma câmara para a outra subsequente.

Sua configuração permite que a água residuária atravesse regiões de elevada concentração de microrganismos ativos que se formam junto ao fundo do reator (zona de reação), pois as chicanas obrigam a água residuária a se movimentar descendente e ascendentemente (Barber e Stuckey, 1999).

Em termos de processo, o reator compartimentado se caracteriza por oferecer a possibilidade de separar algumas das fases da digestão anaeróbia, o que termodinamicamente favorece a formação de metano, liberando na forma de gás, o hidrogênio na primeira ou nas primeiras câmaras. $\mathrm{O}$ hidrogênio formado pode impedir a rápida transformação do ácido propiônico para ácido acético e consequentemente, prejudicar a etapa da metanogênese (Barber e Stuckey, 1999).

Embora não comumente encontrados em grande escala, os reatores compartimentados possuem várias vantagens sobre outros sistemas bem estabelecidos, os quais são apresentados na Tabela 3.2. 
Tabela 3.2 - Principais vantagens dos reatores compartimentados e/ou serial.

\begin{tabular}{l|l}
\hline \multirow{4}{*}{ Construção } & Projeto simples \\
& Não requer partes móveis \\
& Não necessita de mistura mecânica \\
& Baixo custo de construção \\
& Reduzida expansão da manta de lodo \\
& Baixo capital e custos operacionais \\
\hline \multirow{3}{*}{ Biomassa } & Baixa geração de lodo \\
& Elevado tempo de retenção de sólidos \\
& Retenção de biomassa sem necessidade de meio suporte fixo \\
& ou móvel \\
& Não requer separação especial de gás ou lodo \\
& Baixo TRH \\
& Possibilidade de operação intermitente \\
& Extremamente estável a choques de cargas hidráulicas \\
& Proteção contra materiais tóxicos no afluente \\
& Tempos de operação elevado sem desperdício de lodo \\
\hline \multirow{2}{*}{ Operação } &
\end{tabular}

Fonte: Adaptado de Barber e Stuckey (1999).

Segundo Foxon et al., (2004) o reator RAC, devido às suas características tem sido aplicado para os mais diversos tipos de águas residuárias, tanto para as com baixa carga orgânica (esgoto doméstico) como para as com alta concentração de matéria orgânica (agroindústria), com resultados satisfatórios.

No trabalho realizado por Yang e Moengangongo (1987), os autores verificaram que a remoção de matéria orgânica em reatores anaeróbios compartimentados ocorre também por meio de sedimentação e floculação, portanto, o reator funcionaria como unidade de tratamento físico-químico e biológico de remoção de sólidos. Com essas características, os reatores anaeróbios compartimentados têm se apresentado como boa 
alternativa para o tratamento de águas residuárias com altas frações de sólidos suspensos orgânicos.

Yang et al., (1987) utilizando reator ABR (3 câmaras) com volume de 150 L no processamento de melaço com concentrações iniciais de 5,3 g SSV/L ${ }^{-1}$, DQO de 5.000 a $10.000 \mathrm{mg} \cdot \mathrm{L}^{-1}$ e $\mathrm{COV}$ de $5,5 \mathrm{~kg} \mathrm{~m}^{-3} \cdot \mathrm{d}^{-1}$, obtiveram remoção de DQO da ordem de $98 \%$.

Boopathy e Tilche (1991) avaliaram o tratamento de melaço em reator ABR (3 câmaras) com volume de 150 L, concentração de biomassa de 4,01 g SSV/L ${ }^{-1}$, DQO de 115.000 a $990.00 \mathrm{mg} \cdot \mathrm{L}^{-1}, \operatorname{COV} 4,3$ a $28 \mathrm{~kg} \mathrm{~m}^{-3} \cdot \mathrm{d}^{-1}$ e TDH variando entre 5 a 35 dias, obtendo valores de remoção de DQO entre 49 a $88 \%$.

\subsection{Desafios no processamento anaeróbio da vinhaça}

Verifica-se a necessidade de estudos fundamentais para o entendimento e melhoria dos sistemas de digestão da vinhaça de cana de açúcar por meio do uso de reatores anaeróbios de alta taxa (tipo UASB, RAS, batelada, entre outros), visando a manutenção do processo anaeróbio, a otimização do projeto de reatores compactos e eficientes na conversão da matéria orgânica em biogás.

Entre os principais fatores que necessitam ser melhor elucidados para o entendimento do processamento da vinhaça estão, o estudo do carregamento orgânico (COV) e carga orgânica aplicada ao lodo (COAL) associado a diferentes taxas de recirculação do efluente, melhorias no aspecto da produção de biogás e entendimento da população microbiana envolvida no processo. 


\subsubsection{Carga orgânica aplicada na partida e operação de reatores anaeróbios}

Concomitantemente ao avanço da utilização de reatores UASB, foram ressaltadas condições restritivas na capacidade de tratamento e na aplicação desta tecnologia. Os complexos e ainda não elucidados fenômenos da granulação do lodo, as limitações da aplicação de taxas hidráulicas e orgânicas, a flotação dos grânulos, entre outros, são fatores que podem inviabilizar a otimização do processo e a obtenção da máxima conversão da matéria orgânica e produção de biogás (Driessen e Yspeert, 1999; Zaiat, 2004).

A quantidade de matéria orgânica aplicada diariamente ao reator por unidade de volume é definida como a carga orgânica volumétrica (COV), descrita na Equação 2.

$$
\mathrm{COV}=\frac{\mathrm{Q} \cdot \mathrm{S}}{\mathrm{V}}
$$

Onde:

COV: Carga orgânica volumétrica $\left(\mathrm{kg}\right.$ DQO $\left.\mathrm{m}^{-3} \cdot \mathrm{d}^{-1}\right)$

Q: vazão $\left(\mathrm{m}^{-3} \cdot \mathrm{d}^{-1}\right)$

$\mathrm{S}$ : concentração de substrato afluente $\left(\mathrm{kg} \mathrm{DQO} \mathrm{m}^{-3}\right)$

$\mathrm{V}$ : volume do reator $\left(\mathrm{m}^{3}\right)$

De acordo com Piveli (2006), em reatores anaeróbios convencionais, a carga orgânica aplicável, na melhor das hipóteses, chega a 6,0 $\mathrm{kg}$ DQO $\mathrm{m}^{-3} \cdot \mathrm{d}^{-1}$. Já em sistemas de alta taxa, como no reator UASB, esse valor pode variar de 12,0 a 20,0 $\mathrm{kg}$ DQO m${ }^{-3} . \mathrm{d}^{-}$ ${ }^{1}$, podendo ser ainda superior. 
Para efluentes industriais com elevada concentração de matéria orgânica já se aplicou com sucesso, em instalações piloto, COV's da ordem de 45,0 kg DQO m${ }^{-3} . \mathrm{d}^{-1}$, embora os reatores tenham sido projetados para cargas na ordem de $15,0 \mathrm{~kg}$ DQO m${ }^{-3} \cdot \mathrm{d}^{-}$ ${ }^{1}$ (Souza, 2011).

Outro parâmetro diretamente relacionado ao sucesso do projeto de reatores anaeróbios é a carga biológica aplicada ao lodo, também denominada como carga orgânica aplicada ao lodo (COAL). Esta, refere-se à quantidade de matéria orgânica aplicada diariamente ao reator, por unidade de biomassa presente como mostra a Equação 3.

$$
\mathrm{COAL}=\frac{\mathrm{Q} \cdot \mathrm{S}}{\mathrm{M}}
$$

Onde:

COAL: carga orgânica aplicada ao lodo (kg DQO kg STV.d $\left.{ }^{-1}\right)$;

Q: vazão $\left(\mathrm{m}^{-3} \cdot \mathrm{d}^{-1}\right)$;

$\mathrm{S}$ : concentração de substrato afluente $\left(\mathrm{kg} \mathrm{DQO} / \mathrm{m}^{-3}\right)$;

M: massa de microrganismos presentes no reator ( $\mathrm{kg} \mathrm{STV})$.

De acordo com o tipo de efluente a ser tratado, a carga biológica aplicada pode atingir valores em torno de 2,0 kg DQO kg STV.d ${ }^{-1}$. A carga de matéria orgânica ou biológica deve ser estimada em função da atividade metanogênica específica (AME) e da massa de lodo presente no reator (Souza, 2011).

Uma das principais limitações da aplicação tecnológica do reator UASB para o tratamento da vinhaça está relacionada principalmente às dificuldades no processo de 
partida e a manutenção da biomassa ativa no reator, sendo estes fatores agravados com a elevada concentração de matéria e carga orgânica aplicada.

De acordo com Del Nery et al., (2008), considerando que parcela dos pontos limitantes do reator UASB de alta taxa para tratamento da vinhaça está relacionado à manutenção da integridade física e biológica da manta de lodo, estudos de parâmetros hidráulicos e orgânicos aplicados a esta região constituem-se excelentes objetos de investigação, para elucidar fenômenos relacionados ao funcionamento desta configuração de reator com efluentes muito concentrados, como é o caso da vinhaça.

Na Tabela 3.3 são apresentados valores de cargas orgânicas volumétricas aplicadas a diferentes configurações de reatores, empregados no tratamento anaeróbio da vinhaça de cana-de-açúcar.

Constata-se que, não há consenso na literatura de qual devem ser as taxas de carregamento orgânico inicial ou limitante adequado para o tratamento da vinhaça de cana-de-açúcar (seja esta diluída ou não) por meio da utilização de reatores anaeróbios.

Sendo assim, a estipulação e investigação de diferentes cargas orgânicas associadas a taxas de recirculação do efluente aplicadas no tratamento de vinhaça por meio de reatores de alta taxa, ainda é uma questão que merece atenção para o entendimento do processo e alcance da máxima produção de biogás. 
Tabela 3.3 - Valores de COV aplicadas no processamento anaeróbio da vinhaça.

\begin{tabular}{l|ccl}
\hline \multicolumn{1}{c|}{ Autor } & $\begin{array}{c}\text { COV aplicada } \\
\left(\mathrm{kg} \mathrm{DQO} / \mathrm{m}^{-3} . \mathrm{d}^{-1}\right)\end{array}$ & $\begin{array}{c}\text { Configuração } \\
\text { do reator }\end{array}$ & Tipo de vinhaça \\
\hline Gonzalez et al., (1998) & $2,3-7,1$ & $\mathrm{UASB}^{1}$ & Cana-de-açúcar \\
Nandy et al., (2002) & 5,0 & $\mathrm{RAFF}^{3}$ & Cana-de-açúcar \\
Ribas (2006) & $2,85-36$ & $\mathrm{RABS}^{4}$ & Cana-de-açúcar \\
Siqueira (2007) & 20 & $\mathrm{RALF}^{2}$ & Cana-de-açúcar \\
Fernandez et al., (2008) & $3,0-20$ & $\mathrm{RALF}^{2}$ & Cana-de-açúcar \\
Satyawali et al., (2008) & $15-24$ & $\mathrm{UASB}^{1}$ & Cana-de-açúcar \\
Brown et al., (2011) & $0,53-4,5$ & $\mathrm{UASB}^{1}$ & Cana-de-açúcar \\
\hline
\end{tabular}

${ }^{1}$ UASB (reator anaeróbio de fluxo ascendente com manta de lodo); ${ }^{2}$ RALF (reator anaeróbio de leito fluidizado); ${ }^{3} \mathrm{RAFF}$ (reator anaeróbio de filme fixo); ${ }^{4} \mathrm{RABS}$ (reator anaeróbio com biomassa em suspensão).

\subsubsection{Produção de biogás}

O sucesso de qualquer processo biológico, especialmente os de alta taxa, depende da manutenção nos reatores de biomassa adaptada, com elevada atividade microbiológica, e resistente a choques. Para que a biomassa possa ser monitorada, desenvolveram-se técnicas para a avaliação da atividade microbiana. No caso de reatores anaeróbios, essa avaliação visa em especial os microrganismos metanogênicos.

Os microrganismos responsáveis pela produção de metano, classificados como arqueias, são anaeróbios estritos obrigatórios, denominados genericamente de microrganismos metanogênicos. São células procarióticas, que apresentam sequência de RNAr e propriedades fenotípicas diferentes das bactérias. Methanobacterium e Methanobacillus na forma de bastonetes e os Methanococcus, Methanothrix e Methanosarcina na forma de cocos, são os principais gêneros de microrganismos que têm sido identificados em condições mesofílicas (Metcalf e Eddy, 2003). 
A quantificação indireta das arqueias metanogênicas na conversão de substratos solúveis em $\mathrm{CO}_{2}$ e $\mathrm{CH}_{4}$ pode ser realizada aplicando-se o denominado teste de Atividade Metanogênica Específica (AME) que, a partir de quantidades prédeterminadas de biomassa e de substrato, em condições propícias à digestão anaeróbia, fornece a produção de metano em relação à massa de sólidos voláteis.

Para se avaliar de forma fiel, a atividade metanogênica de determinado lodo devese alimentá-lo com substrato que suporte apenas a atividade metabólica dos microrganismos metanogênicos, em condições controladas em laboratório (Aquino et al., 2007).

A concentração da DQO digerida na amostra para formar o metano medido, pode ser calculada a partir do volume de gás produzido, sabendo-se que a digestão anaeróbia de 4,0 g de DQO resulta na produção de $1,0 \mathrm{~g}$ de metano, sendo $1 \mathrm{~mol} / \mathrm{L}=16 \mathrm{mg}$ $\mathrm{CH}_{4} / \mathrm{L}^{-1}=64 \mathrm{mg} \mathrm{DQO} / \mathrm{L}^{-1}$. O teste da AME dá a massa de DQO que pode ser digerida pelo lodo expressa em g DQO/g SVT.d ${ }^{-1}$ e a produção de metano que pode ser esperada.

Verifica-se a inexistência de um protocolo padrão para a determinação da atividade metanogênica de lodos anaeróbios. Assim, foram propostos diversos métodos para avaliar a atividade microbiana anaeróbia, conforme apresentado por Penna (1994); Monteggia (1997); Borges (2004); Aquino et al., (2007); Chernicharo (2007), entre outros.

Para a determinação da atividade metanogênica de lodos anaeróbios, os protocolos diferem entre si tanto nos procedimentos adotados para a incubação do lodo (concentração de biomassa, tipo e concentração de substrato, relação alimento/microrganismo, tipo e concentração de nutrientes, tempo de incubação, dentre outros), quanto para a quantificação do metano produzido (Foresti et al., 1999). 
Em relação aos procedimentos de incubação, observa-se que a comunidade científica utiliza diferentes concentrações iniciais de substrato e biomassa, sendo que alguns pesquisadores preferem utilizar glicose como substrato, ao passo que outros utilizam ácido acético ou uma mistura dos principais ácidos orgânicos intermediários da digestão anaeróbia (ácido acético, propiônico e butírico).

Em relação à quantificação de metano, há métodos mais sofisticados, como os que empregam cromatógrafo a gás e/ou respirômetros interfaciados com microcomputadores, bem como métodos simplificados que se baseiam na purificação do metano do biogás seguida de sua determinação volumétrica (Aquino et al., 2007).

Aquino et al., (2007) afirma que a inexistência de um procedimento padrão para a determinação da AME, dificulta a comparação dos resultados obtidos em diferentes casos, e limita a aplicabilidade e disseminação do teste de AME como ferramenta de controle dos processos anaeróbios.

O acompanhamento da atividade metanogênica da biomassa utilizada na partida e ao longo do período de operação dos reatores anaeróbios processando vinhaça, torna-se de grande importância, tendo em vista a evolução e comportamento dos microrganismos frente à variação da imposição de taxas de carregamento orgânico na produção de biogás.

\subsubsection{Investigação da diversidade microbiana}

O estudo da comunidade microbiana no ambiente ou em sistemas de tratamento é de fundamental importância para o entendimento dos processos metabólicos envolvidos na degradação e conseqüente melhoria dos processos de tratamento. O uso de técnicas 
de biologia molecular para descrever populações em comunidades naturais vem ocorrendo desde meados de 1980 (Amann et al., 1995).

Os microrganismos dos reatores biológicos constituem a parte viva e mais ativa da matéria orgânica, podendo atuar como indicadores capazes de refletir mudanças sutis nas propriedades de reatores de tratamento, bem antes que alterações nos teores de matéria orgânica possam ser observadas.

As técnicas de biologia molecular, tais como reação em cadeia da polimerase (Polymerase Chain Reaction - PCR), eletroforese em gel de gradiente desnaturante (Denaturing Gradient Gel Electrophoresis - DGGE) e sequenciamento filogenético, são utilizadas para o estudo da comunidade microbiana presente em lodos e biofilmes dos reatores anaeróbios.

A técnica de PCR/DGGE permite caracterizar qualitativamente a diversidade microbiana presente nas amostras microbiológicas, onde a partir das bandas do gel de DGGE obtido, pode-se observar a variação na estrutura da comunidade microbiana em diferentes etapas da operação dos sistemas (Hirasawa, 2007).

Verifica-se que, essas técnicas convencionais de biologia molecular utilizadas em conjunto, têm sido empregadas no estudo de comunidades microbianas complexas e de lodos granulados no processamento de diferentes águas residuárias.

Neste contexto, a partir do exposto verifica-se que os reatores anaeróbios compartimentados têm sido utilizados com resultados satisfatórios no tratamento de águas residuárias.

No que se refere ao processamento da vinhaça de cana-de-açúcar por meio do emprego de reatores tipo RAC, esses trabalhos são escassos, necessitando dessa forma de estudos direcionados à investigação do potencial de tratabilidade deste efluente, produção de biogás, bem como a investigação da aplicação de cargas orgânicas, taxas 
hidráulicas, taxas de recirculação e o acompanhamento da comunidade microbiana da biomassa no reator. 


\section{Materale Métoods}

Neste capítulo são descritos as unidades experimentais, as operações e os procedimentos empregados no desenvolvimento e na condução do presente trabalho.

As instalações experimentais foram implantadas na área de reatores piloto do Laboratório de Processos Biológicos (LPB), do Departamento de Hidráulica e Saneamento (SHS), da Escola de Engenharia de São Carlos (EESC/USP).

Na Figura 4.1 é apresentado o fluxograma esquemático simplificado da metodologia empregada no desenvolvimento do trabalho.

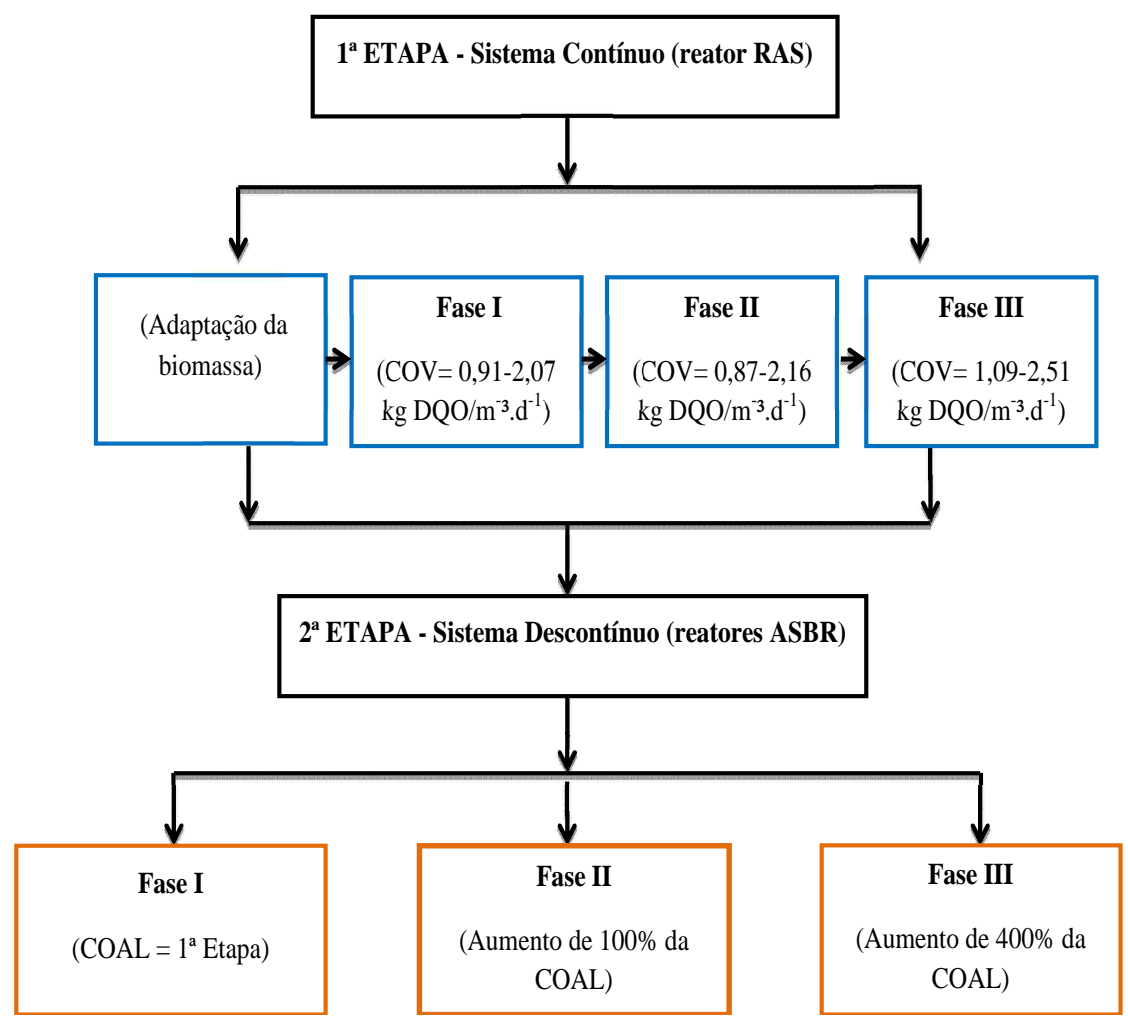

Figura 4.1 - Fluxograma simplificado da metodologia empregada na condução do trabalho. 


\subsection{Reator Anaeróbio Serial - RAS}

Um reator anaeróbio serial (RAS) em escala de bancada foi utilizado neste trabalho, no processamento da vinhaça de cana-de-açúcar em temperatura na faixa mesofílica, visando a conversão da matéria orgânica na produção de biogás.

O reator RAS foi confeccionado em material de PVC (Policloreto de polivinila), contendo quatro câmaras (compartimentos) dispostas em série, denominadas C1 (câmara 1), C2 (câmara 2), C3 (câmara 3) e C4 (câmara 4), cada qual com capacidade para $5 \mathrm{~L}$, totalizando um volume de $20 \mathrm{~L}$, diâmetro interno de $0,13 \mathrm{~m}$ e altura de $0,80 \mathrm{~m}$.

Nas Figuras 4.2 e 4.3 são apresentados o esquema de montagem e a imagem dos componentes do reator RAS utilizado, respectivamente.

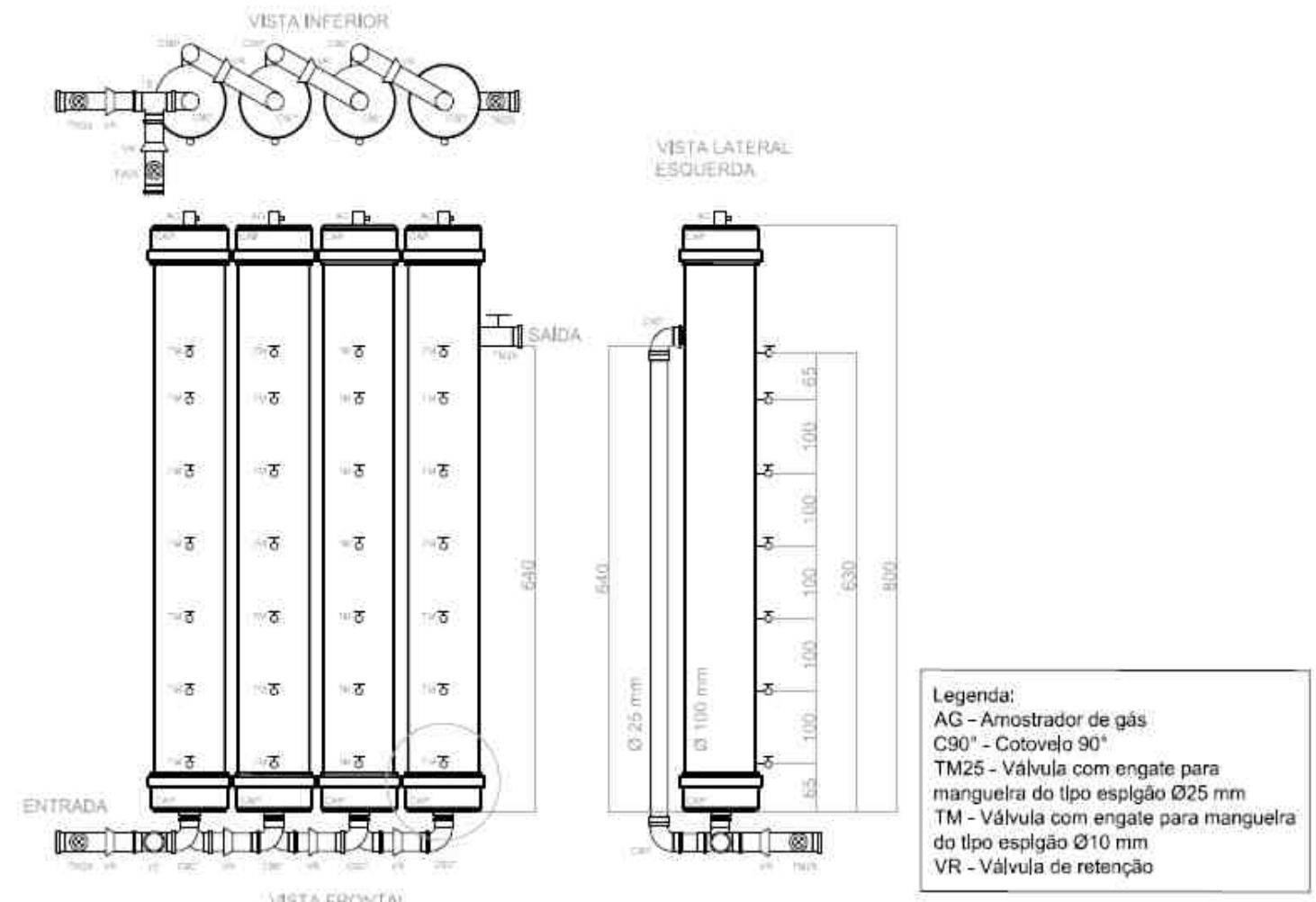

Figura 4.2. Esquema de montagem do reator anaeróbio serial (RAS) utilizado. 


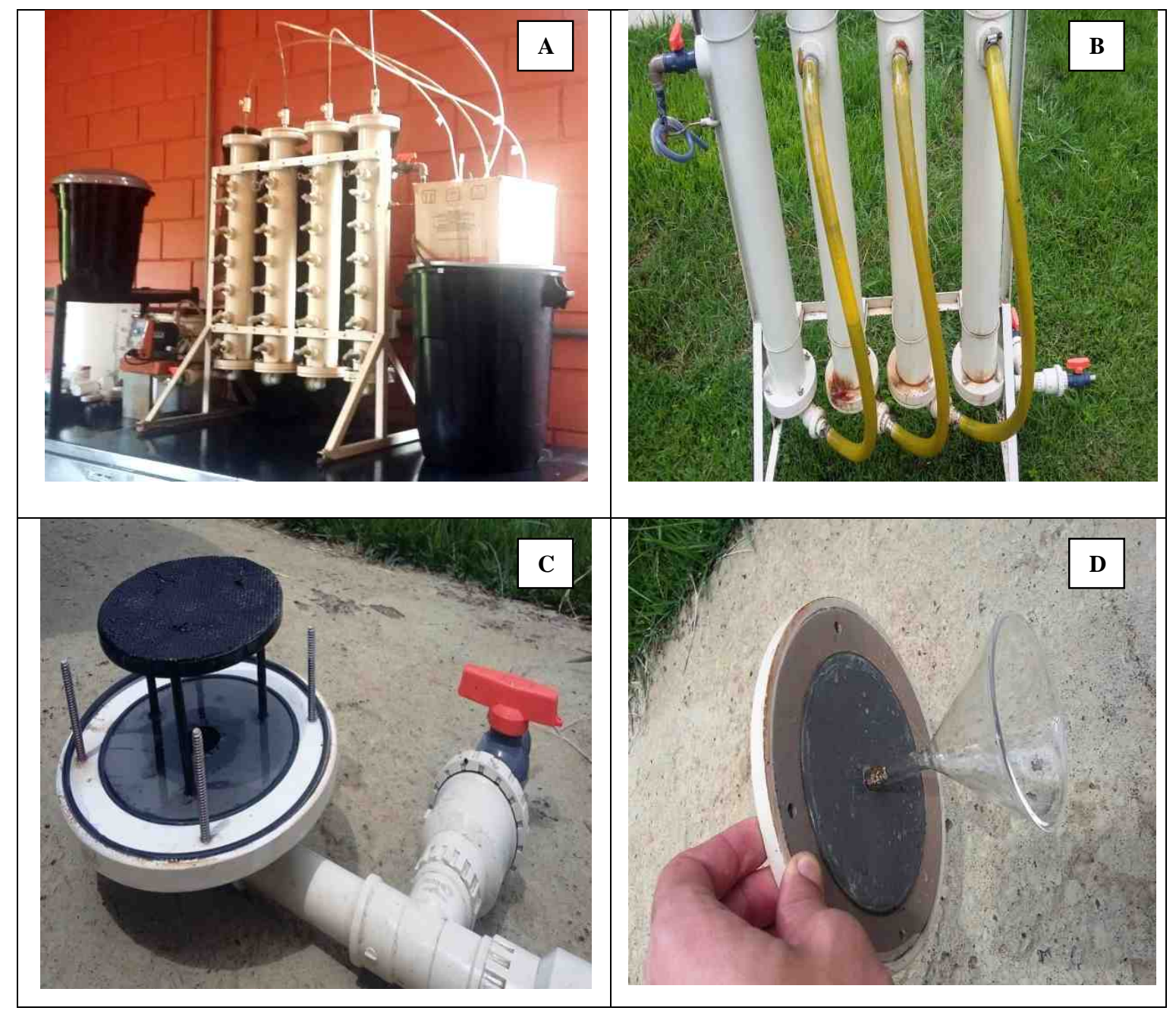

Figura 4.3 - Componentes do reator RAS utilizado. (A: vista frontal do reator; B: tubulações condutoras do efluente; C: tela de retenção de sólidos; D: separador).

O sistema engloba dois tanques, onde foi realizado o armazenamento da vinhaça utilizada na alimentação e do efluente final tratado, respectivamente. A vinhaça foi encaminhada a partir de tanque de alimentação para o reator em regime contínuo, utilizando-se bomba dosadora ProMinent Dosiertechnik®, modelo D-69123 Heidelberg, com temporizador de programação acoplado ao sistema de recalque.

Cada câmara do reator é composta por zona de reação na parte inferior $( \pm 0,4 \mathrm{~m}$ de altura), separador gás-sólido interno tipo funil invertido (Figura 4.3 D), construído em material acrílico, sendo o fluxo de escoamento da fase líquida, ascendente de uma câmara para outra. Logo, o afluente da $\mathrm{C}$, era a vinhaça bruta contida no tanque de 
alimentação; o afluente da C2 era o efluente da C1; o afluente da C3 era o efluente da $\mathrm{C} 2$, e o afluente da $\mathrm{C} 4$ era o efluente da C3.

\subsection{Reatores Anaeróbios operados em Batelada Sequencial (ASBR)}

Foram utilizados na segunda etapa do trabalho (Etapa 2), reatores anaeróbios operados em regime de batelada sequencial (ASBR), utilizando-se frascos de Durhan com volume de 2 L para a degradação anaeróbia da vinhaça sob imposição de aumentos da carga orgânica aplicada ao lodo (COAL).

Para efeito de comparação dos resultados da Etapa 1 com a Etapa 2, os frascos reatores, também foram denominados de $\mathrm{C} 1, \mathrm{C} 2, \mathrm{C} 3$ e C4, correspondendo às condições operacionais individualizadas em termos de afluente, biomassa e carga orgânica aplicada de cada câmara do reator RAS, respectivamente.

Na Figura 4.4 é apresentado o fluxograma esquemático dos ensaios em batelada utilizando os frascos reatores.

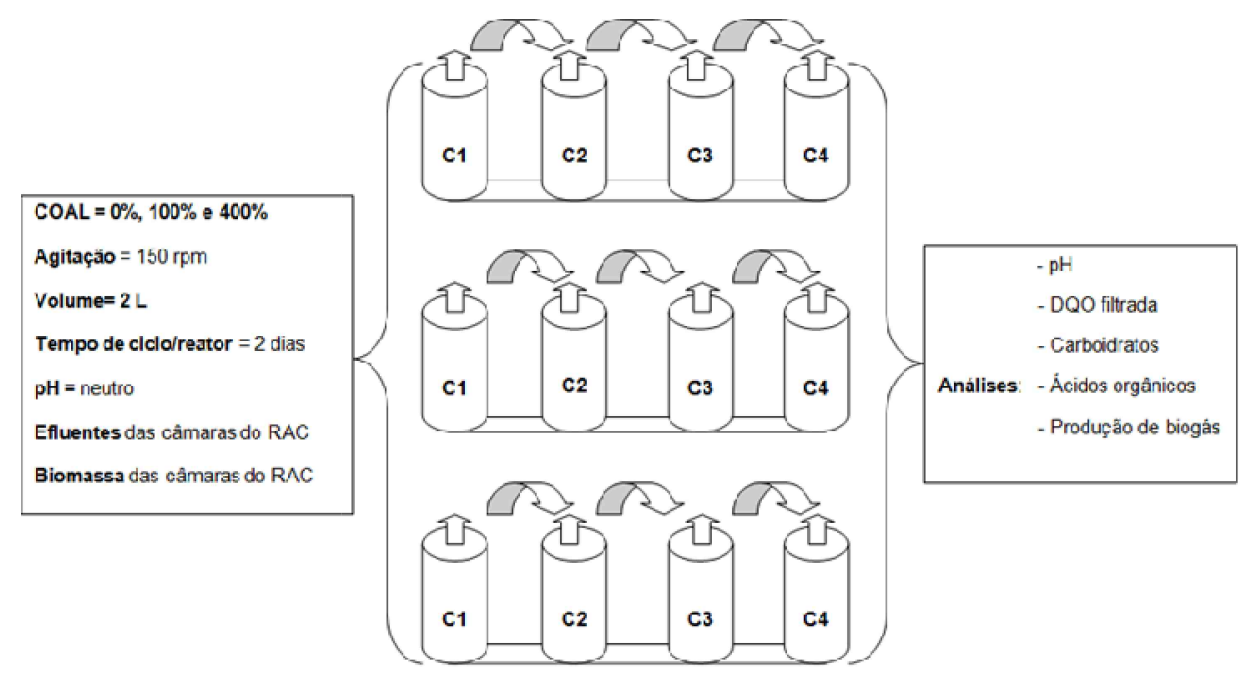

Figura 4.4 - Esquema dos ensaios utilizando frascos reatores operados em batelada sequencial processando vinhaça. 
Nos ensaios em sistema descontínuo foi utilizada a mesma biomassa (lodo granular) proveniente de cada câmara do reator RAS ao final de sua operação na Etapa 1, para a execução dos ensaios em frascos Durhan, simulando o processo da “compartimentação serial” no processamento da vinhaça de cana-de-açúcar, porém, com a aplicação de maiores taxas de carregamento orgânico aplicado ao lodo (COAL). Para tanto, a segunda etapa do trabalho (Etapa 2) foi constituída por 3 fases distintas, descritas no item 4.5.2.

\subsection{Vinhaça de cana-de-açúcar}

As amostras de vinhaça bruta utilizada na alimentação do reator RAS e nos ensaios em batelada foram coletas da Usina Rio Pardo, localizada no município de Cerqueira César/SP, sendo armazenada sob refrigeração, mantendo-se assim a mesma característica qualitativa durante todo o período de execução do trabalho.

Por se tratar de uma água residuária industrial com elevada concentração de matéria orgânica em termos de demanda bioquímica de oxigênio (DBO), demanda química de oxigênio (DQO) e apresentar baixos valores de $\mathrm{pH}$, as amostras de vinhaça bruta coletadas, foram diluídas com água de torneira para atingir uma DQO de aproximadamente 20 g. $\mathrm{L}^{-1}$ (diluição 1:10 v/v) e, tamponadas com bicarbonato de sódio $\left(0,5 \mathrm{~g} \mathrm{NaHCO}_{3} / 1,0 \mathrm{~g} \mathrm{DQO}\right)$ antes de serem submetidas à alimentação do reator.

Preliminarmente, foi realizada a caracterização qualitativa da vinhaça (Tabela 4.1), por meio dos parâmetros de $\mathrm{DBO}, \mathrm{DQO}, \mathrm{pH}$, alcalinidade, carboidratos, ácidos

voláteis, NTK, fenol, fosfato e metais, de acordo com os procedimentos e 
recomendações descritos no Standart Methods for Examination of Water and Wastewater (APHA, 2005).

Tabela 4.1. Caracterização da vinhaça de cana de açúcar utilizada.

\begin{tabular}{|c|c|c|}
\hline Parâmetro & Unidade & Concentração \\
\hline DBO & $\mathrm{mg} \mathrm{O}_{2} \mathrm{~L}^{-1}$ & 8500 \\
\hline DQO & $\mathrm{mg} \cdot \mathrm{L}^{-1}$ & 18400 \\
\hline $\mathrm{pH}$ & - & 7,20 \\
\hline Alcalinidade & $\mathrm{mg} \cdot \mathrm{L}^{-1}$ & 2749,0 \\
\hline Carboidratos & $\mathrm{mg} \cdot \mathrm{L}^{-1}$ & 1940,12 \\
\hline NTK & $\mathrm{mg} \cdot \mathrm{L}^{-1}$ & 236,11 \\
\hline Fenol & $\mathrm{mg} . \mathrm{L}^{-1}$ & 0,768 \\
\hline Fosfato & $\mathrm{mg} \cdot \mathrm{L}^{-1}$ & 28 \\
\hline Cádmio & $\mathrm{mg} \cdot \mathrm{L}^{-1}$ & 0,024 \\
\hline Chumbo & $\mathrm{mg} \cdot \mathrm{L}^{-1}$ & 0,40 \\
\hline Cobre & $\mathrm{mg} \cdot \mathrm{L}^{-1}$ & 0,298 \\
\hline Cromo total & $\mathrm{mg} \cdot \mathrm{L}^{-1}$ & 0,050 \\
\hline Cobalto & mg. $\mathrm{L}^{-1}$ & 0,163 \\
\hline Ferro & $\mathrm{mg} . \mathrm{L}^{-1}$ & 52,7 \\
\hline Manganês & $\mathrm{mg} \cdot \mathrm{L}^{-1}$ & 5,23 \\
\hline Níquel & $\mathrm{mg} \cdot \mathrm{L}^{-1}$ & 0,285 \\
\hline Zinco & $\mathrm{mg} \cdot \mathrm{L}^{-1}$ & 1,270 \\
\hline Cálcio & $\mathrm{mg} \cdot \mathrm{L}^{-1}$ & 506 \\
\hline Magnésio & $\operatorname{mg} . \mathrm{L}^{-1}$ & 180 \\
\hline Sódio & $\mathrm{mg} \cdot \mathrm{L}^{-1}$ & 20,7 \\
\hline Potássio & $\mathrm{mg} \cdot \mathrm{L}^{-1}$ & 860 \\
\hline Sulfato & mg. $L^{-1}$ & 320 \\
\hline
\end{tabular}




\subsection{Inoculação do reator RAS}

Foi adicionado como inóculo em cada câmara do reator, lodo mesofílico granulado proveniente de um reator UASB em escala real tratando efluente de abatedouro de aves (Indústria Rosaves Ltda), utilizando volume de 2,5 L em cada câmara, totalizando um volume de 10 L. A caracterização do lodo de inóculo utilizado na partida do reator RAS é apresentada na Tabela 4.2.

Tabela 4.2 - Caracterização do lodo de inóculo utilizado na partida do RAS.

\begin{tabular}{lc}
\hline \multicolumn{1}{c}{ Parâmetro } & Concentração $\left(\right.$ g. $\left.^{-\mathbf{1}}\right)$ \\
\hline Sólidos totais (ST) & $58,290 \pm 3,56$ \\
Sólidos totais fixos (STF) & $16,720 \pm 2,93$ \\
Sólidos totais voláteis (STV) & $41,388 \pm 2,05$ \\
\hline
\end{tabular}

\subsection{Procedimento experimental}

Tendo em vista a escassez de referências na literatura utilizando esta configuração de reator no tratamento de vinhaça de cana-de-açúcar, inicialmente foi realizada a montagem dos aparatos experimentais, bem como a determinação de procedimentos e metodologias operacionais para a partida do reator anaeróbio serial.

Os procedimentos experimentais do trabalho foram divididos em duas principais etapas e suas respectivas fases, descritas na Tabela 4.3. 
Tabela 4.3 - Etapas e fases experimentais empregadas na condução do trabalho.

\begin{tabular}{|c|c|c|c|c|}
\hline Etapa & Fase & Reator & Sistema & Condição operacional \\
\hline \multirow{4}{*}{$\mathbf{1}^{\mathbf{a}}$} & - & \multirow{4}{*}{ RAS } & \multirow{4}{*}{ Contínuo } & Adaptação \\
\hline & $\mathrm{I}$ & & & $\begin{array}{c}\text { Aumento gradual da COV de } \\
0,91 \text { a } 2,07 \mathrm{~kg} \mathrm{DQO} / \mathrm{m}^{-3} \cdot \mathrm{d}^{-1}\end{array}$ \\
\hline & II & & & $\begin{array}{l}\text { Aumento gradual da COV de } \\
0,87 \text { a } 2,16 \mathrm{~kg} \text { DQO } / \mathrm{m}^{-3} \cdot \mathrm{d}^{-1}\end{array}$ \\
\hline & III & & & $\begin{array}{c}\text { Aumento gradual da COV de } \\
1,09 \text { a } 2,51 \mathrm{~kg} \text { DQO} / \mathrm{m}^{-3} \cdot \mathrm{d}^{-1}\end{array}$ \\
\hline \multirow{3}{*}{$2^{\mathbf{a}}$} & $\mathrm{I}$ & \multirow{3}{*}{ ASBR } & \multirow{3}{*}{ Batelada } & $\begin{array}{c}\text { Aplicação de COAL final da } \\
\text { Etapa } 1\end{array}$ \\
\hline & II & & & Aumento de $100 \%$ da COAL \\
\hline & III & & & Aumento de $400 \%$ da COAL \\
\hline
\end{tabular}

COV: Carga orgânica volumétrica; COAL: Carga orgânica aplicada ao lodo.

\subsubsection{Etapa 1 - Operação e monitoramento do RAS em sistema contínuo}

Nesta primeira etapa do trabalho constituída pelas Fases I, II e III, foi investigado o tratamento da vinhaça pelo reator RAS em regime contínuo, sob a imposição de aumentos gradativos de carregamento orgânico.

Inicialmente o reator foi operado com reduzidas vazões de alimentação e carregamento orgânico. Esta fase, denominada como período de adaptação, teve por objetivo propiciar condições de aclimatação da biomassa submetida à alimentação com vinhaça de cana de açúcar, por aproximadamente 30 dias.

As fases subsequentes (I, II e III), consistiram na operação e monitoramento do reator RAS com aumentos gradativos de vazão $\left(1,0\right.$ a 2,5 ${\left.\mathrm{L} . \mathrm{d}^{-1}\right)}^{-1}$ sem a recirculação do efluente, tempo de detenção hidráulica (TDH) variando entre 19 a 8 dias, aplicação de cargas orgânicas volumétricas (COV) global de 0,91 a 2,51 kg DQO $/ \mathrm{m}^{-3} \cdot \mathrm{d}^{-1} \mathrm{e}$, carga orgânica aplicada ao lodo (COAL) global de 0,06 a 0,17 kg DQO/kg STV.d ${ }^{-1}$. 
A COV aplicada foi aumentada gradativamente por meio de incrementos semanais na vazão de alimentação do reator. $\mathrm{O}$ aumento da vazão foi condicionado à concentração de ácidos voláteis totais (AVT), que no máximo poderia ser 20\% superior em cada câmara em relação à câmara anterior. Ultrapassada essa condição limite, a carga orgânica aplicada era reduzida em aproximadamente $50 \%$, e o incremento semanal de vazão novamente iniciado até que a condição limite fosse observada.

De modo geral, essa condicionante caracterizou as Fases I, II e III da primeira etapa do trabalho.

A Fase I iniciou-se na $5^{\mathrm{a}}$ semana e perdurou até a $11^{\mathrm{a}}$ semana de operação do reator, quando foi constatada a primeira obstrução das câmaras e então, tomada a medida de reduzir a vazão de alimentação em aproximadamente 50\% (12 ${ }^{\mathrm{a}}$ semana), para o restabelecimento da eficiência operacional do reator.

A Fase II teve início na $13^{\mathrm{a}}$ semana, após o restabelecimento operacional do reator em termos de concentração de ácidos voláteis totais, até a $28^{a}$ semana de operação, quando novamente foi constatada a extrapolação da concentração de ácidos $\left(29^{a}\right.$ semana). Novamente a vazão de alimentação foi reduzida em aproximadamente $50 \%$ para o restabelecimento da eficiência do reator.

Já a Fase III, iniciou-se na $30^{\text {a }}$ até a $41^{\text {a }}$ semana, finalizando neste período a operação e o monitoramento do reator em regime estacionário, com obtenção da carga orgânica volumétrica global de $2,51 \mathrm{~kg} \mathrm{DQO} / \mathrm{m}^{-3} \cdot \mathrm{d}^{-1}$.

$\mathrm{O}$ monitoramento do reator foi realizado pelos parâmetros de $\mathrm{pH}$, DQO bruta, DQO filtrada, carboidratos, alcalinidade, ácidos voláteis totais, ácidos voláteis orgânicos, sólidos, produção e composição de biogás.

Ao final da operação do reator, foram também realizados ensaios para a determinação da atividade metanogênica específica (AME), exames microscópicos 
(óptico e MEV) e análises de biologia molecular (PCR/DGGE e sequenciamento filogenético), para o monitoramento da biomassa.

Buscou-se por meio de tais procedimentos analíticos, avaliar e correlacionar a diversidade microbiana da biomassa presente em cada câmara, com os parâmetros operacionais do reator RAS na remoção de matéria orgânica e produção de biogás.

Na Tabela 4.4 é apresentado um resumo contendo os valores de vazão de alimentação, TDH, COV e COAL que foram obtidos no transcorrer da operação do reator RAS em regime contínuo.

Tabela 4.4 - Resumo dos parâmetros obtidos na operação do reator RAS.

\begin{tabular}{|c|c|c|c|c|}
\hline Etapa 1 & $\begin{array}{l}\text { Vazão } \\
\left(L^{-1} \cdot d\right)\end{array}$ & $\begin{array}{l}\text { TDH } \\
\text { (d) }\end{array}$ & $\begin{array}{c}\mathrm{COV}_{\text {Global }} \\
\left(\mathrm{kg} \mathrm{DQO} / \mathrm{m}^{3} \cdot \mathrm{d}\right)\end{array}$ & $\begin{array}{c}\text { COAL }_{\text {Global }} \\
(\mathrm{kg} \mathrm{DQO/kgSTV.d)}\end{array}$ \\
\hline Adaptação & $0,50-0,86$ & $40-23$ & $0,42-0,78$ & $0,030-0,052$ \\
\hline Fase I & $1,04-2,38$ & $19-8$ & $0,91-2,07$ & $0,061-0,138$ \\
\hline Fase II & $1,23-2,13$ & $16-9$ & $0,87-2,16$ & $0,058-0,128$ \\
\hline Fase III & $1,20-2,50$ & $17-8$ & $1,09-2,51$ & $0,073-0,167$ \\
\hline
\end{tabular}

A priori, estava prevista no projeto inicial do trabalho, a aplicação de taxas de recirculação do efluente (200\% e 400\%) final, retornando-o para o reservatório de alimentação da C1. No entanto, constatou-se por meio de testes iniciais que mesmo com a adoção de pequenas taxas de recirculação do efluente ( $25 \%$, por exemplo), houve a piora no processo operacional e desbalanceamento dos parâmetros monitorados.

Os valores da carga orgânica volumétrica global $\left(\mathrm{COV}_{\text {global }}\right)$ e carga orgânica aplicada ao lodo global (COAL $\mathrm{Clobal}_{\text {) }}$ aplicadas foi determinada de acordo com as equações 4 e 5 , respectivamente, nos quais Q é a vazão de alimentação; $S$ é a concentração de DQO; $\mathrm{V}_{\mathrm{T}}$ é o volume total do reator e $\mathrm{M}$ é a concentração do lodo. 


$$
\mathrm{COV}_{\mathrm{g}}=\frac{\mathrm{Q} . \mathrm{S}}{\mathrm{V}_{\mathrm{T}}} \quad \text { Eq. (4) } \quad \mathrm{COAL}_{\mathrm{g}}=\frac{\mathrm{Q} . \mathrm{S}}{\mathrm{M}} \quad \text { Eq. (5) }
$$

Em relação ao cálculo das cargas orgânicas volumétricas individuais e cargas orgânicas aplicadas ao lodo individuais para cada câmara do reator, foram utilizadas as equações 6 a 13, respectivamente, em que $Q$ é a vazão de alimentação; $S_{V}$ é a concentração de DQO da vinhaça bruta; $S_{C x}$ é a concentração de DQO efluente das câmaras $\left(\mathrm{C} 1, \mathrm{C} 2\right.$ e C3); $\mathrm{V}_{\mathrm{Cx}}$ é o volume de cada câmara $(5 \mathrm{~L})$ e $\mathrm{M}_{\mathrm{Cx}}$ a concentração do lodo em cada câmara.

$$
\begin{aligned}
& \mathrm{COV}_{\mathrm{C} 1}=\frac{\mathrm{Q} . \mathrm{S}}{\mathrm{V}_{\mathrm{C} 1}} \quad \text { Eq. (6) } \quad \mathrm{COAL}_{\mathrm{C} 1}=\frac{\mathrm{Q} . \mathrm{S}}{\mathrm{M} 1} \quad \text { Eq. (7) } \\
& \mathrm{COV}_{\mathrm{C} 2}=\frac{\mathrm{Q} . \mathrm{S} 1}{\mathrm{~V}_{\mathrm{C} 2}} \quad \text { Eq. (8) } \quad \mathrm{COAL}_{\mathrm{C} 2}=\frac{\mathrm{Q} . \mathrm{S} 1}{\mathrm{M} 2} \quad \text { Eq. (9) } \\
& \mathrm{COV}_{\mathrm{C} 3}=\frac{\mathrm{Q} . \mathrm{S} 2}{\mathrm{~V}_{\mathrm{C} 3}} \quad \text { Eq. (10) } \quad \mathrm{COAL}_{\mathrm{C} 3}=\frac{\mathrm{Q} . \mathrm{S} 2}{\mathrm{M} 3} \quad \text { Eq. (11) } \\
& \mathrm{COV}_{\mathrm{C} 4}=\frac{\mathrm{Q} . \mathrm{S} 3}{\mathrm{~V}_{\mathrm{C} 4}} \quad \text { Eq. (12) } \quad \mathrm{COAL}_{\mathrm{C} 4}=\frac{\mathrm{Q} . \mathrm{S} 3}{\mathrm{M} 4} \quad \text { Eq. (13) }
\end{aligned}
$$

\subsubsection{Etapa 2 - Operação e monitoramento dos ASBR em sistema descontínuo}

$\mathrm{Na}$ segunda etapa do trabalho (Etapa 2), foram realizados ensaios em bateladas utilizando frascos Durhan em triplicata (reatores C1, C2, C3 e C4), com a finalidade principal de verificar e/ou até mesmo simular o "fenômeno da compartimentação" do 
reator RAS frente à imposição de maiores taxas de carga orgânica aplicadas, procurando o entendimento da dinâmica da produção de ácidos orgânicos, biogás e o comportamento da comunidade microbiana. Para tanto, a segunda etapa consistiu em três fases distintas (Fase I, II e II), a saber:

- Fase I: Replicação dos valores de carga orgânica aplicada ao lodo (COAL) individualizadas de cada câmara, obtidas ao final da operação do reator RAC na Etapa 1 (Tabela 4.5);

- Fase II: Aplicação de aumento de taxa de $100 \%$ sobre os valores de COAL obtidas ao final da Etapa 1; e

- Fase III: Aplicação de aumento de taxa de $400 \%$ sobre os valores de COAL final obtidos da Etapa 1.

Na Tabela 4.5 são apresentados os parâmetros operacionais obtidos ao final da operação do reator RAS na Etapa 1, os quais foram utilizados para o cálculo das cargas orgânicas aplicadas e os procedimentos empregados na realização dos ensaios em regime de batelada.

Tabela 4.5 - Parâmetros ao final da operação do RAC (Etapa 1) empregados nos ensaios em batelada.

\begin{tabular}{lcccc}
\hline Condição Operacional & C1 & C2 & C3 & C4 \\
\hline DQO & & & \\
Afluente $\left(\mathrm{g} \cdot \mathrm{L}^{-1}\right)$ & $\pm 17,5$ & $\pm 5,0$ & $\pm 2,5$ & $\pm 1,3$ \\
Vazão $\left(\mathrm{L} \cdot \mathrm{d}^{-1}\right)$ & 3,3 & 3,3 & 3,3 & 3,3 \\
STV $\left(\mathrm{g} \cdot \mathrm{L}^{-1}\right)$ & 57,95 & 52,08 & 50,89 & 47,36 \\
COV $\left(\mathrm{kgDQO} / \mathrm{m}^{-3} \cdot \mathrm{d}^{-1}\right)$ & 10,0 & 3,30 & 1,65 & 0,86 \\
COAL $\left(\mathrm{kgDQO} / \mathrm{STV} \cdot \mathrm{d}^{-1}\right)$ & 0,56 & 0,17 & 0,08 & 0,04 \\
\hline
\end{tabular}


Os ensaios consistiram no processamento da vinhaça empregando equipamento de agitação constante de $150 \mathrm{rpm}$ (shaker), temperatura controlada de $27 \pm 3{ }^{\circ} \mathrm{C}$, com aplicação de taxas de carga orgânica (COAL) e tempo de ciclo de 2 dias (48 horas) para cada frasco reator $(\mathrm{C} 1, \mathrm{C} 2, \mathrm{C} 3$ e $\mathrm{C} 4)$, totalizando um ciclo de 8 dias para cada condição experimental.

A adoção do tempo de ciclo de 2 dias para cada frasco reator, teve como premissa, a replicação das mesmas condições operacionais obtidas no sistema contínuo, onde foi verificado um TDH final na operação do reator RAS (Fase III) de aproximadamente 8 dias.

$\mathrm{O}$ afluente do frasco reator $\mathrm{C} 1$ foi constituído pela vinhaça preparada da mesma forma como na alimentação do RAS na Etapa 1 (sistema contínuo). Em relação ao afluente da $\mathrm{C} 2$, este foi o efluente da $\mathrm{C} 1$ processado após tempo de ciclo de 48 horas, e assim sucessivamente até o frasco reator $\mathrm{C} 4$, obtendo o efluente final.

Em relação à biomassa (inóculo) utilizada em cada frasco reator, a mesma foi proveniente das respectivas câmaras correspondentes do reator RAS ao final da sua operação.

Ao final do tempo de ciclo estipulado para cada frasco reator, foi adotado um período de 60 min com agitação desligada, para a sedimentação dos sólidos, e posterior coleta do sobrenadante para as determinações analíticas e utilização nos ensaios seguintes.

Para a avaliação de desempenho do sistema proposto foram coletadas amostras antes e após o tratamento, para as análises de DQO filtrada, carboidratos, pH e ácidos orgânicos voláteis. A produção e composição de biogás $\left(\mathrm{CH}_{4}\right.$ e $\left.\mathrm{CO}_{2}\right)$ foram determinadas por meio de cromatografia gasosa. 
Ao final dos ensaios das Fases I, II e III, foram também coletadas amostras da biomassa de cada frasco reator para a realização de análises de PCR/DGGE.

\subsection{Caracterização da biomassa microbiana}

A caracterização da biomassa microbiana do reator anaeróbio serial foi determinada por meio de ensaios de atividade metanogênica específica, produção de metano, medição do diâmetro médio de grânulos, exames microscópicos de contraste de fase, microscopia eletrônica de varredura (MEV) e análises de biologia molecular (PCR/DGGE e sequenciamento).

\subsubsection{Atividade metanogênica específica (AME)}

Foram realizados ensaios para a determinação da atividade metanogênica da biomassa presente em cada câmara, utilizada na partida (lodo de inóculo) e ao final do período de operação do reator RAS na Etapa 1.

Os ensaios foram conduzidos em triplicatas em frascos de Durhan com capacidade de $500 \mathrm{~mL}$, sendo $300 \mathrm{~mL}$ constituído de fase líquida e $200 \mathrm{~mL}$ de fase gasosa (headspace). A fase líquida foi composta por solução de macro e micronutrientes

(Tabela 4.6), 10 g SSV/L ${ }^{-1}$ de lodo proveniente de cada câmara do RAS, de acordo com os procedimentos e recomendações descritas por Penna (1994).

Como fonte orgânica de carbono foi utilizado solução de acetato de sódio (14 $\mathrm{mM})$ e formiato de sódio $(6 \mathrm{mM})$, respectivamente. $\mathrm{O}$ pH da solução foi ajustado para 7 , utilizando solução de bicarbonato de sódio. Os frascos foram então colocados sob fluxo 
de gás nitrogênio (100\%) durante 5 min, selados e colocados em câmera com agitação (shaker) de $50 \mathrm{rpm}$ e temperatura de $30 \pm 1{ }^{\circ} \mathrm{C}$.

Na Tabela 4.6 é apresentada a composição das soluções de macro/micronutrientes e os substratos orgânicos, utilizados nos ensaios de AME, baseado na metodologia e procedimentos descritos em Penna (1994).

Tabela 4.6 - Composição dos substratos e soluções de macro e micronutrientes utilizadas nos ensaios de AME.

\begin{tabular}{|c|c|}
\hline Solução I: Macronutrientes & Concentração $\left(\mathrm{mg.L}^{-1}\right)$ \\
\hline $\mathrm{NH}_{4} \mathrm{Cl}$ & 73,6 \\
\hline $\mathrm{KH}_{2} \mathrm{PO}_{4}$ & 13,6 \\
\hline$\left(\mathrm{NH}_{4}\right)_{2} . \mathrm{SO}_{4}$ & 13,6 \\
\hline Solução II: Micronutrientes & Concentração $\left(\mathrm{mg.L}^{-1}\right)$ \\
\hline $\mathrm{FeCl}_{2} \cdot 4 \mathrm{H}_{2} \mathrm{O}$ & 2000 \\
\hline $\mathrm{CoCl}_{2} \cdot 6 \mathrm{H}_{2} \mathrm{O}$ & 2000 \\
\hline $\mathrm{MnCl}_{2} .4 \mathrm{H}_{2} \mathrm{O}$ & 500 \\
\hline $\mathrm{CuCl}_{2} \cdot 2 \mathrm{H}_{2} \mathrm{O}$ & 30 \\
\hline$\left(\mathrm{NH}_{4}\right)_{6} \cdot \mathrm{Mo}_{7} \cdot \mathrm{O} 24.4 \mathrm{H}_{2} \mathrm{O}$ & 50 \\
\hline $\mathrm{NiCl}_{2} \cdot 6 \mathrm{H}_{2} \mathrm{O}$ & 10 \\
\hline $\mathrm{ZnCl}_{2} \mathrm{H}_{2} \mathrm{O}$ & 50 \\
\hline $\mathrm{H}_{3} \mathrm{PO}_{3}$ (solução saturada) & $1 \mathrm{~mL}$ \\
\hline Solução III: Substratos Orgânicos & Concentração (mM) \\
\hline Acetato & 14 \\
\hline Formiato & 6 \\
\hline
\end{tabular}

\subsubsection{Produção de metano e composição do biogás}

Em virtude da dificuldade em quantificar a produção volumétrica de metano ao longo da operação do reator RAS por métodos de deslocamento e gasômetros da marca Ritter®, a produção de metano obtida neste trabalho foi determinada segundo 
Chernicharo (2007), pela produção teórica de metano gerado por grama de DQO removida, de acordo com Equação (14).

Para o cálculo de conversão do metano produzido em biogás, foi considerado, como referência, o biogás com uma concentração de $75 \%$ a $80 \%$ de metano (Metcalf \& Eddy, 2003; Chernicharo, 2007).

$$
V_{C_{4}}=\frac{D \quad C_{4}}{K(t)} \quad \text { Eq. (14) }
$$

Onde:

$\mathrm{V}_{\mathrm{CH} 4}$ : Volume teórico de metano produzido (L);

DQO $_{\mathrm{CH} 4}$ : Carga de DQO removida no reator e convertida em metano (gDQO);

$\mathrm{K}(\mathrm{t})$ : Fator de correção para a temperatura operacional do reator (gDQO/L);

O fator de correção foi obtido para a temperatura de operação do reator RAS a partir da Equação (15):

$$
K(t)=\frac{P . K}{R . T} \quad \text { Eq. (15) }
$$

Onde:

P: Pressão atmosférica (1 atm);

$\mathrm{K}$ : DQO correspondente a um mol de $\mathrm{CH}_{4}\left(1 \mathrm{~mol} \mathrm{CH}_{4} / 64 \mathrm{gDQO}\right)$;

R: Constante dos gases ideais (0,08206 atm.L/mol.K);

$\mathrm{T}$ : Temperatura operacional do reator $(\mathrm{K})$. 
A composição em termos de percentual de metano e dióxido de carbono contido no biogás ao logo da operação do reator, bem como nos ensaios de atividade metanogênica específica, foi analisada por cromatografia gasosa, utilizando cromatógrafo de gases GC-210 SHIMADZU com detector de condutividade térmica (DCT).

As leituras de biogás foram realizadas a partir da utilização de seringa plástica de $1 \mathrm{~mL}$, com volume de injeção do biogás no cromatógrafo de $3 \mathrm{~mL}$.

O volume de gás metano produzido nos ensaios de AME foram determinadas aproximadamente após $30 \mathrm{~min}$ do início do experimento. Nas primeiras 12 horas de ensaio, as leituras eram realizadas em intervalos de 120 min e, nos dias subsequentes, ocorriam duas a três vezes ao dia.

As determinações experimentais foram realizadas até a obtenção de valores estáveis na produção de metano durante a fase estacionária de crescimento microbiano. Para a obtenção do cálculo da concentração de metano, foi utilizada curva de calibração.

O volume de gás produzido foi corrigido para as condições normais de temperatura e pressão (CNTP), conforme apresentado na Equação (16).

$$
\frac{P 1 * V 1}{T 1}=\frac{P 2 * V 2}{T 2} \quad \text { Eq. (16) }
$$

Em que:

$P=$ pressão atmosférica (atm);

$V=$ volume $(\mathrm{L})$;

$T=$ temperatura $(\mathrm{K})$;

$1=$ condições na CNTP $\left(1 \mathrm{~atm}, 25{ }^{\circ} \mathrm{C}\right)$;

2 = condições de laboratório. 
O cálculo da AME foi determinado a partir da velocidade de conversão do substrato a metano, pela inclinação da curva do gráfico obtido (trecho de inclinação máxima).

\subsubsection{Caracterização microbiana por microscopia óptica e MEV}

Foram realizados exames microscópicos do lodo de inóculo e da biomassa presente em cada câmara do reator anaeróbio serial ao final da sua operação, quando o mesmo encontrava-se em regime estacionário aparente.

As amostras de biomassa das câmaras C1, C2, C3 e C4, foram coletadas em distintos pontos amostradores distribuídos ao longo de cada reator (câmara).

Para a microscopia óptica de contraste de fase, foi utilizado microscópio Olympus BH2, com câmara acoplada para captura e aquisição de imagem (Programa Image ProPlus 4.5).

As análises de microscopia eletrônica de varredura (MEV) foram realizadas junto ao Departamento de Engenharia de Materiais (DEM), da Escola de Engenharia de São Carlos (EESC/USP), por meio da utilização de microscópio Inspect F-50 (FEI, Nederland), de acordo com os procedimentos descritos por Nation (1983). Para tanto, os grânulos foram divididos ao meio para amostragem de três diferentes regiões como ilustrado na Figura 4.5. 


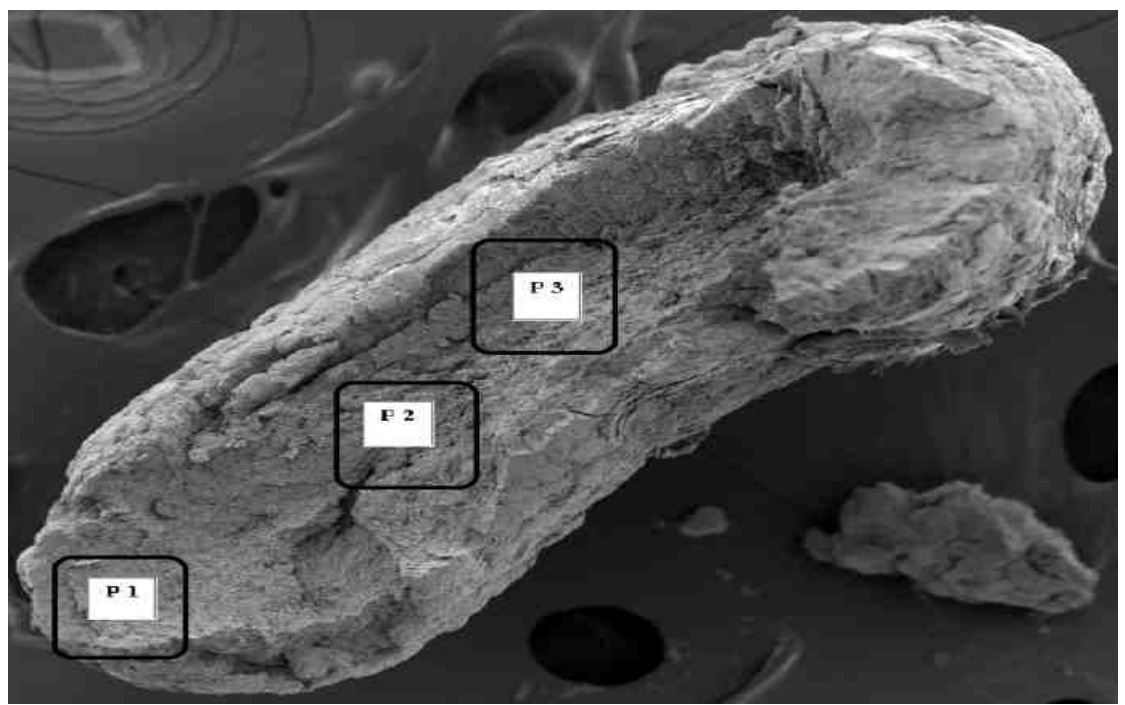

Figura 4.5 - Corte transversal dos grânulos com as respectivas dimensões dos pontos de amostragem para MEV. P1 $(10 \mu \mathrm{m}), \mathrm{P} 2(10 \mu \mathrm{m})$ e P3 $(10 \mu \mathrm{m})$.

\subsubsection{Caracterização da diversidade microbiana por técnicas de biologia molecular}

A caracterização e a diversidade da comunidade microbiana do RAS foram investigadas por meio do emprego das técnicas de reação em cadeia da polimerase (PCR), seguida de eletroforese em gel de gradiente desnaturante (DGGE) e sequenciamento filogenético.

O DNA genômico das amostras foi obtido com extração de lise celular com pérolas de vidro, fenol tamponado com tris e clorofórmio de acordo com o protocolo modificado descrito por Griffths et al., (2000).

A amplificação da polimerase em cadeia (PCR) foi realizada com set primer 968FGC - 1401R para domínio Bacteria (Nubel et al., 1996) e set primer 1100FGC 1400R para domínio Archaea (Kudo et al., 1997).

As concentrações do gradiente desnaturante utilizadas foram de $45 \%$ e $65 \%$ para o domínio Bacteria, 40\% e 65\% para o domínio Archaea, respectivamente. As condições 
da corrida foram de $75 \mathrm{~V}$ por 16 horas a temperatura constante de $60^{\circ} \mathrm{C}$ (Muyzer et al.,1993). Brometo de etídeo (diluída 10.000 vezes) foi usado como solução fluorescente. $\mathrm{O}$ aparelho utilizado para leitura dos padrões de bandas foi o sistema de foto documentação L.Pix Touch (Loccus Biotecnologia) sob exposição a 254 nm UV.

Os perfis das bandas padrões do DGGE obtidas, foram utilizados na construção das matrizes por meio do Software BioNumerics versão 3.5 (Applied Maths, Bélgica), servindo como base para os cálculos do coeficiente de similaridade Jarcard e agrupamento com UPGMA (Unweighted Pair Group Method with Arithmetic Averages). O cálculo do índice de diversidade (Shannon-Wiener) foi determinado pelo software Past ${ }^{\circ}$.

O sequenciamento foi realizado utilizando a plataforma Miseq - Illumina, 2x250 ciclos, no gene $16 \mathrm{~S}$ das regiões V3 e V4 com os set primer 341F (5' CCTACGGGNGGCWGCAG - 3`) e o 785R (5' - GACTACHVGGGTATCTAATCC 3`), de acordo com metodologia descrita por Klindworth et al., 2013.

$\mathrm{Na}$ análise de bioinformática, a filtragem dos reads de baixa qualidade, sequências de adaptadores e vetores foi realizada pelo programa Seqyclean, utilizando como cutoff bases com qualidade inferior a 24 QScore. As bases de dados de contaminantes usadas foram a Univec. Para a análise de metagenômica foi utilizada a base de dados RDP (Cole et al 2014) de Archaea e Bacteria. O pipeline usado foi o do pacote QIIME v 1.9 (Caporaso et al 2010) em 3 etapas: 1) Concatenação dos readspaired-end; 2) Filtragem, procura e identificação de OTUs. Nessa etapa o programa também realiza uma montagem de novo dos reads que não tiveram hit com a base de dados e procura hit contra todas as bases disponíveis; 3) Análises de rarefação, alfa e beta diversidade. Para essas análises foi levada em consideração a profundidade de cobertura da amostra com menos reads para utilizar o parâmetro sampling-depth de forma adequada. A 
diversidade alfa (Shannon, Simpson and Dominance) foi realizada usando o Software Past ${ }^{1}$.

\subsection{Métodos analíticos}

O monitoramento do reator anaeróbio serial foi realizado semanalmente por meio de amostras coletadas na entrada (alimentação) e na saída das câmaras C1, C2, C3 e C4. Para tanto, foram determinados os parâmetros de DQO bruta, DQO filtrada, carboidratos, alcalinidade a bicarbonato, ácidos voláteis totais, pH, Sólidos ( $\mathrm{ST}, \mathrm{SF}, \mathrm{SV}$, SST, SSF, SSV, SDT, SDF e SDV), produção de metano e composição do biogás.

Na Tabela 4.7 é apresento a frequência e os métodos analíticos empregados no monitoramento do desempenho do reator.

Tabela 4.7. Parâmetros, frequência e métodos analíticos empregados no monitoramento do desempenho do RAS.

\begin{tabular}{lccc}
\hline \multicolumn{1}{c}{ Parâmetro } & Frequência & Método analítico & Referência \\
\hline Alcalinidade & 2 x/semana & Titulométrico & APHA (2005) \\
Ácidos voláteis totais & 2 x/semana & Titulométrico & APHA (2005) \\
DQO bruta e filtrada & 2 x/semana & Colorimétrico & APHA (2005) \\
pH & 2 x/semana & Potenciométrico & APHA (2005) \\
Carboidratos & 2 x/semana & Espectrofotométrico & Dubois et al., (1956) \\
Série de sólidos & 1 x/semana & Gravimétrico & APHA (2005) \\
Produção de metano & 2 x/semana & CNTP & Chernicharo (1997) \\
$\begin{array}{l}\text { Composição de } \\
\text { biogás }\end{array}$ & $2 \times /$ semana & Cromatografia gasosa & APHA (2005) \\
\hline
\end{tabular}




\subsection{Análise estatística}

Os resultados provenientes do monitoramento em sistema contínuo do reator RAS (Etapa 1) e dos ensaios em batelada (Etapa 2) foram analisados por meio de análise de variância (ANOVA), usando teste F para avaliar se houve interação estatisticamente significativa entre a carga orgânica aplicada versus eficiência de remoção de DQO, e entre a carga orgânica aplicada versus a produção de metano.

Para as análises estatísticas, valores de $p<0,05$ foram considerados significantes e foi utilizado o software STATISTICA versão 13.0. 


\section{Resultaoos E Discussaio}

Neste item são apresentados os resultados e discussões referentes às duas etapas do trabalho, bem como os resultados do tratamento estatístico realizado.

São apresentados os dados referentes ao monitoramento do reator RAS em sistema contínuo; o resultado dos ensaios de atividade metanogênica especifica (AME); a caracterização da biomassa microbiana por meio de exames microscópicos, PCR/DGGE e sequenciamento filogenético; bem como os resultados do monitoramento dos reatores operados em batelada sequencial e do tratamento estatístico dos resultados.

\subsection{ETAPA 1 - OPERAÇÃO DO REATOR RAS EM SISTEMA CONTÍNUO}

\subsubsection{Desempenho do reator anaeróbio serial - RAS}

$\mathrm{O}$ reator anaeróbio serial foi mantido à temperatura ambiente $\left(25 \pm 4^{\circ} \mathrm{C}\right)$ durante todo o período de operação, sob pressão atmosférica de 690,7 mmHg (São Carlos/SP).

Nas Figuras 5.1 a 5.4 são apresentadas as variações do comportamento das cargas orgânica volumétrica aplicadas para cada câmara do RAS ( $\left.\mathrm{COV}_{\text {individual }}\right)$, os valores de $\mathrm{COV}_{\text {global }}$ considerando o volume total do reator e as cargas orgânicas aplicadas ao lodo ( $\mathrm{COAL}_{\text {individual }}$ e $\left.\mathrm{COAL} \mathrm{L}_{\text {global }}\right)$ durante o período da operação, respectivamente. As Fases

I, II e III corresponderam aos períodos de aumento gradativo da carga orgânica volumétrica submetida ao reator, respectivamente. 


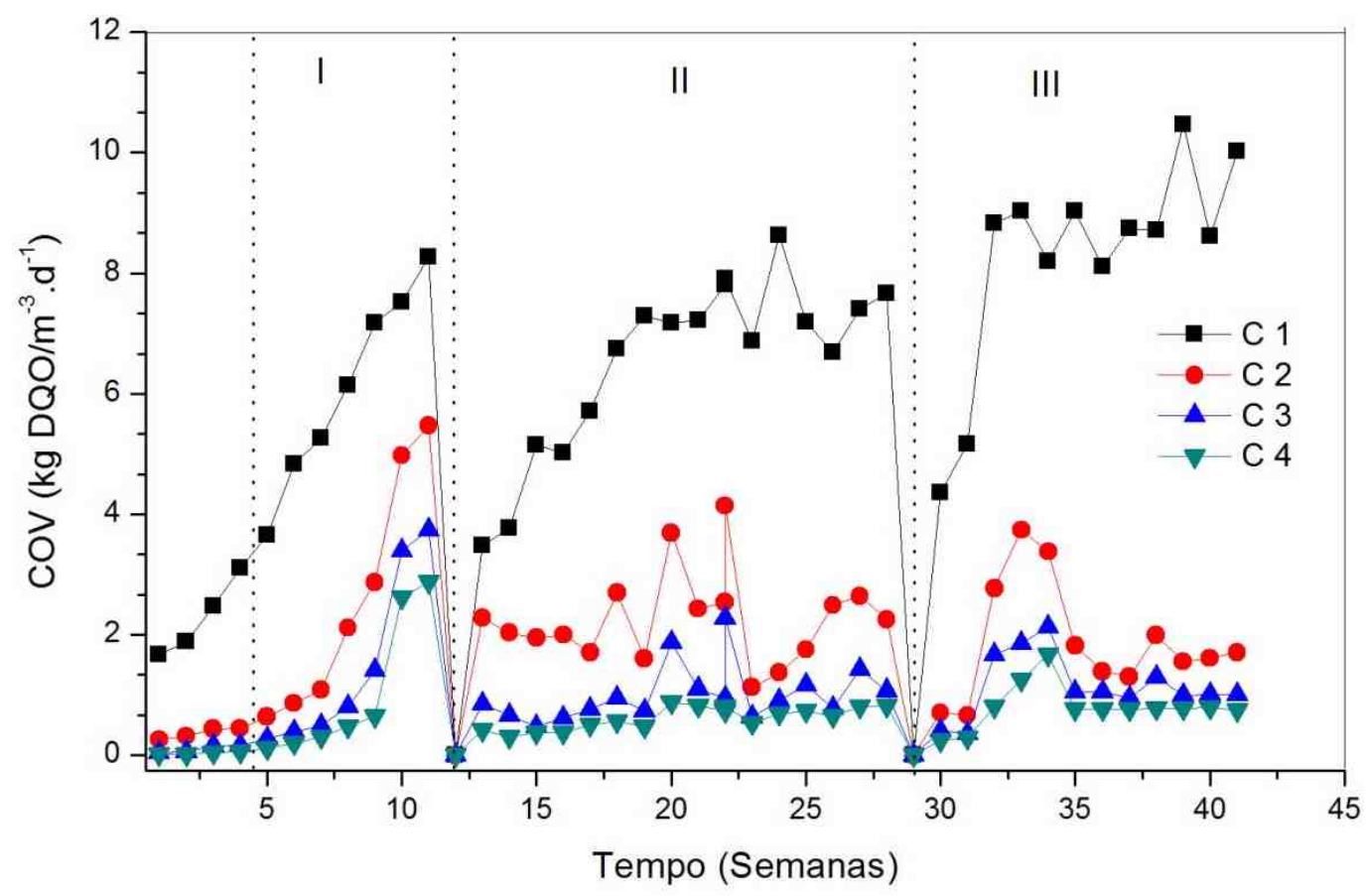

Figura 5.1 - Variação temporal da carga orgânica volumétrica $\left(\mathrm{COV}_{\text {individual }}\right)$ para as câmaras C1, C2, C3 e C4 no período de operação do reator RAS.

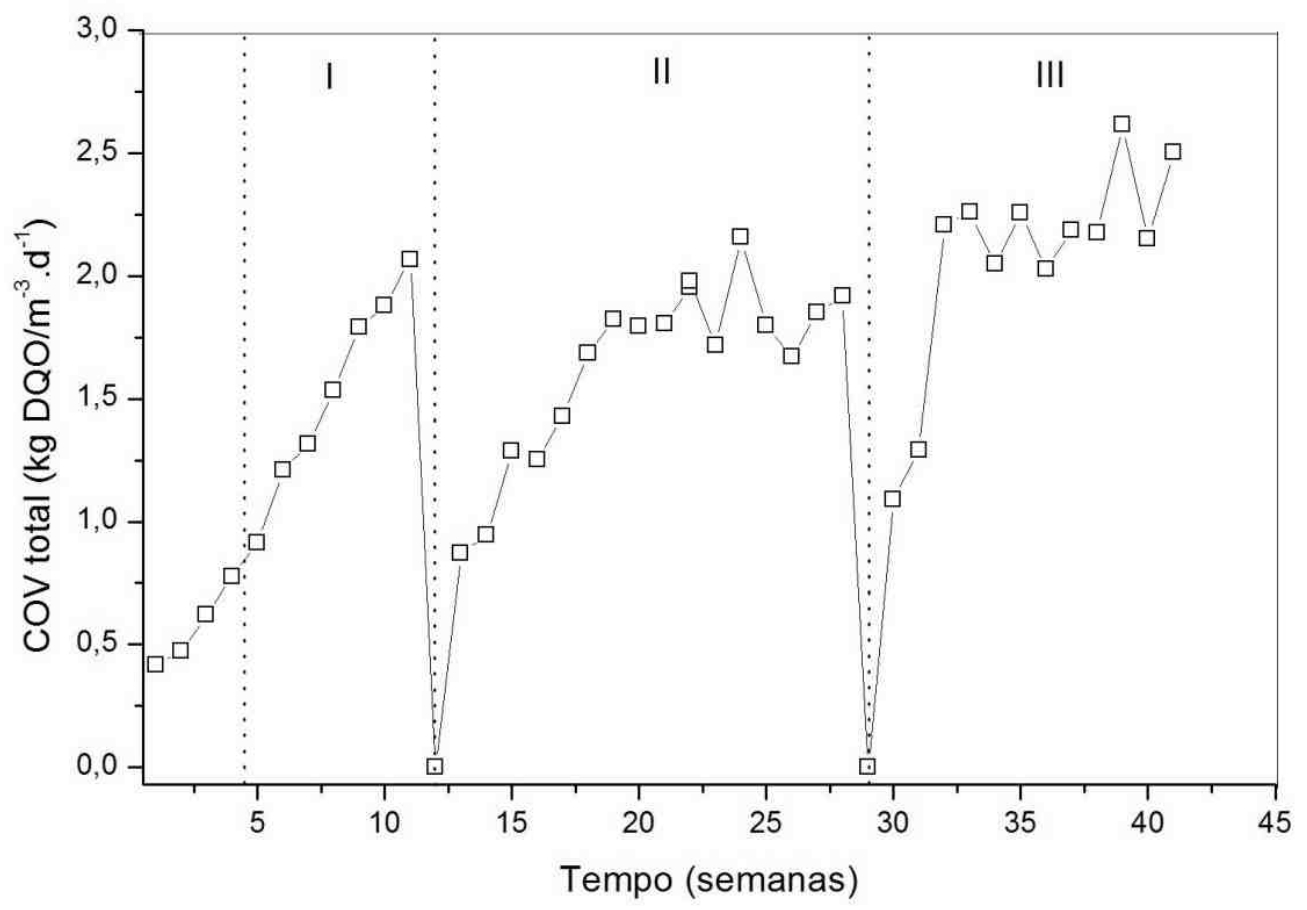

Figura 5.2 - Comportamento da carga orgânica volumétrica global $\left(\mathrm{COV}_{\text {global }}\right)$ no decorrer do período de operação do reator RAS. 


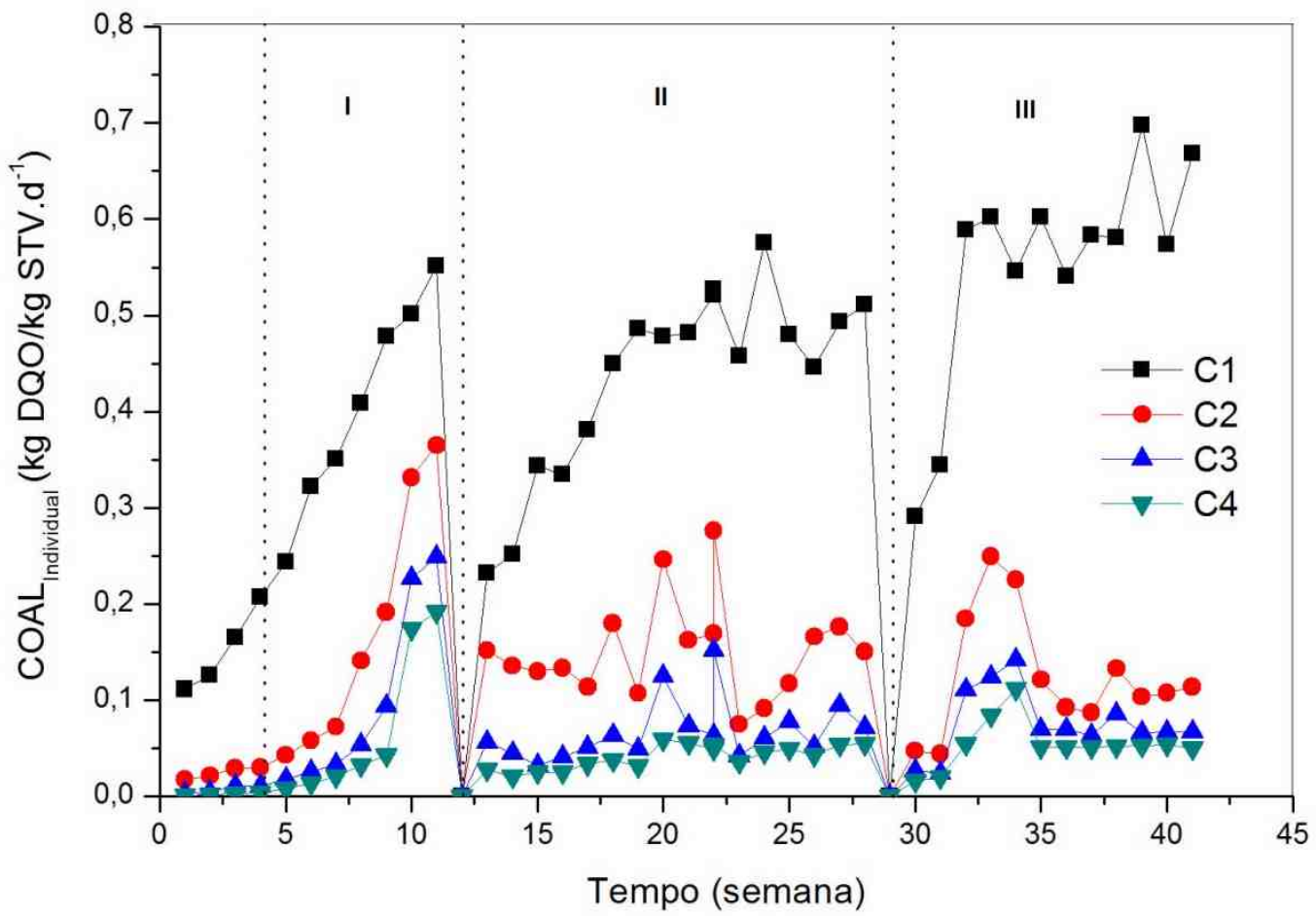

Figura 5.3 - Variação temporal da carga orgânica aplicada ao lodo $\left(\mathrm{COAL}_{\text {individual }}\right)$ para as câmaras C1, C2, C3 e C4 no período de operação do reator RAS.

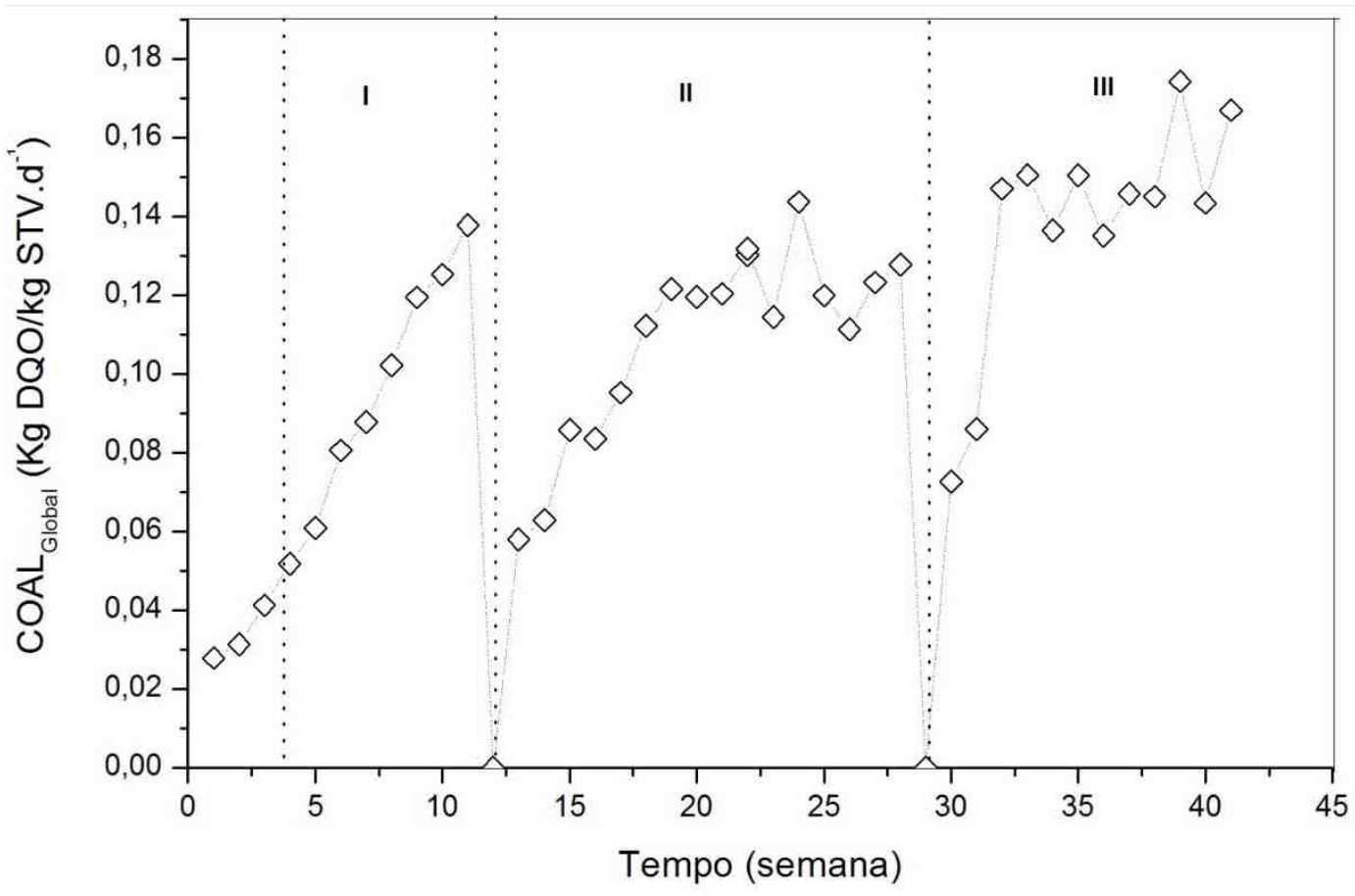

Figura 5.4 - Comportamento da carga orgânica global aplicada ao lodo (COAL $\mathrm{Clobal})$ no decorrer do período de operação do reator RAS. 
Durante o período de adaptação do lodo de inóculo às condições operacionais do reator RAS, foram aplicados reduzidos valores de $\mathrm{COV}_{\text {global }}$ em torno de 0,42 a $0,78 \mathrm{~kg}$ DQO $\mathrm{m}^{-3} \cdot \mathrm{d}^{-1}$ (Figura 5.2). Essa fase inicial da operação compreendeu período de 30 dias, alcançando valores de $\mathrm{COV}_{\text {individual }}$ ao final deste período (Figura 5.1) na ordem de 3,11; 0,45; 0,17 e 0,06 kg DQO $\mathrm{m}^{-3} \cdot \mathrm{d}^{-1}$ para $\mathrm{C} 1, \mathrm{C} 2, \mathrm{C} 3$ e C4, respectivamente.

Os valores de COAL global obtidos na fase de adaptação (Figura 5.4) ficaram na faixa de 0,03 a 0,05 kg DQO kg STV.d ${ }^{-1}$. Em relação aos valores de COAL individual para C1, C2, C3 e C4, esses foram de 0,207; 0,030; 0,011 e 0,004 kg DQO kg STV.d ${ }^{-1}$, respectivamente (Figura 5.3).

Posteriormente nas Fases I, II e III, a carga orgânica imposta ao reator, foi aumentada gradativamente por meio de incrementos na vazão de alimentação aplicadas semanalmente. Para esse período da operação, foram alcançados valores mais elevados de COV e COAL para as quatro câmaras do RAS.

Os valores de $\mathrm{COV}_{\text {global }}$ obtidos oscilaram entre 0,91 a 2,07 $\mathrm{kg}$ DQO m $\mathrm{m}^{-3} \cdot \mathrm{d}^{-1}$ para a Fase I; 0,90 a $1,92 \mathrm{~kg}$ DQO $\mathrm{m}^{-3} \cdot \mathrm{d}^{-1}$ para a Fase II; e 1,09 a 2,50 $\mathrm{kg}$ DQO m $\mathrm{m}^{-3} \cdot \mathrm{d}^{-1}$ para a Fase III. Em relação aos valores de COAL global obtidos para as Fases I, II e III esses foram de 0,061 a 0,138 kg DQO kg STV.d ${ }^{-1} ; 0,058$ a 0,128 kg DQO kg STV.d $\mathrm{d}^{-1}$; e 0,073 a 0,167 kg DQO kg STV.d ${ }^{-1}$, respectivamente.

Em relação aos valores individuais médios de COV obtidos ao longo da operação do reator na Etapa 1 para $\mathrm{C} 1, \mathrm{C} 2, \mathrm{C} 3$ e C4, estes foram de 6,73 $\pm 2,34 \mathrm{~kg}$ DQO m${ }^{-3} \cdot \mathrm{d}^{-1}$; $2,13 \pm 1,20 \mathrm{~kg}$ DQO $\mathrm{m}^{-3} \cdot \mathrm{d}^{-1} ; 1,12 \pm 0,79 \mathrm{~kg}$ DQO $\mathrm{m}^{-3} \cdot \mathrm{d}^{-1}$ e $0,74 \pm 0,58 \mathrm{~kg}$ DQO m${ }^{-3} \cdot \mathrm{d}^{-1}$ respectivamente. Já para a COAL, os valores médios verificados durante a operação do reator foram de 0,45 \pm 0,14 kg DQO kg STV.d ${ }^{-1} ; 0,07 \pm 0,05 \mathrm{~kg}$ DQO kg STV.d $\mathrm{d}^{-1} ; 0,16$ \pm 0,08 kg DQO kg STV.d $\mathrm{d}^{-1}$ e 0,05 \pm 0,04 kg DQO kg STV.d $\mathrm{d}^{-1}$ para C1, C2, C3 e C4, respectivamente. 
De maneira geral, observa-se a partir dos valores de $\mathrm{COV}_{\text {global }}$ e $\mathrm{COAL}_{\text {global }}$ (Figuras 5.2 e 5.4) que ambos apresentaram tendência em seguir o comportamento da C1 (câmara 1), fato que pode ser relacionado ao balanço global das cargas orgânicas maiores que este compartimento deteve ao longo das Fases I, II e III.

Verifica-se ainda através das Figuras 5.1 a 5.4 uma queda nos valores de COV e COAL para a $12^{\mathrm{a}}$ e $29^{\mathrm{a}}$ semana de operação (início das Fases II e III, respectivamente). Esse acontecido pode ser creditado ao entupimento das tubulações, que conduzem os efluentes de uma câmara para outra, verificado nesse período.

Este episódio foi caracterizado pela expansão do leito de lodo decorrente da formação de microbolhas do biogás presentes no interior das câmaras, carreando os sólidos da $\mathrm{C} 1$ para $\mathrm{C} 2$, e assim sucessivamente até a $\mathrm{C}$, bloqueando o fluxo da fase líquida que alimentava as câmaras de modo ascendente.

Como estratégia operacional e medida corretiva, na $12^{\mathrm{a}}$ semana de operação $\left(85^{\circ}\right.$ dia), o reator foi aberto para colocação de micro peneira no fundo das câmaras e a vazão de alimentação foi reduzida em $50 \%$, justificando o ponto de queda nos valores de COV e COAL verificados nesse período.

Persistindo o entupimento verificado na $29^{\mathrm{a}}$ semana $\left(203^{\circ}\right.$ dia), o reator novamente foi reaberto para limpeza e instalação de separadores na parte superior de cada câmara, reduzindo dessa forma, o arraste de biomassa da C1 para C2, C2 para C3 e da C3 para C4.

Os problemas constatados na $12^{\mathrm{a}}$ e $29^{\mathrm{a}}$ semanas da operação do reator caracterizaram o início das Fases II e III, respectivamente.

Para a verificação do comportamento operacional do reator na primeira etapa do trabalho (Etapa 1), foram realizadas análises de DQO bruta, DQO filtrada, carboidratos, 
$\mathrm{pH}$, alcalinidade parcial e total, ácidos voláteis totais, ácidos graxos voláteis, sólidos, produção de metano e composição do biogás.

Os dados referentes ao monitoramento de desempenho do RAS em termos de concentração de DQO, eficiências de remoção individual e global de DQO bruta para cada câmara ao longo do período de operação, são apresentados nas Figuras 5.5 a 5.7, respectivamente.

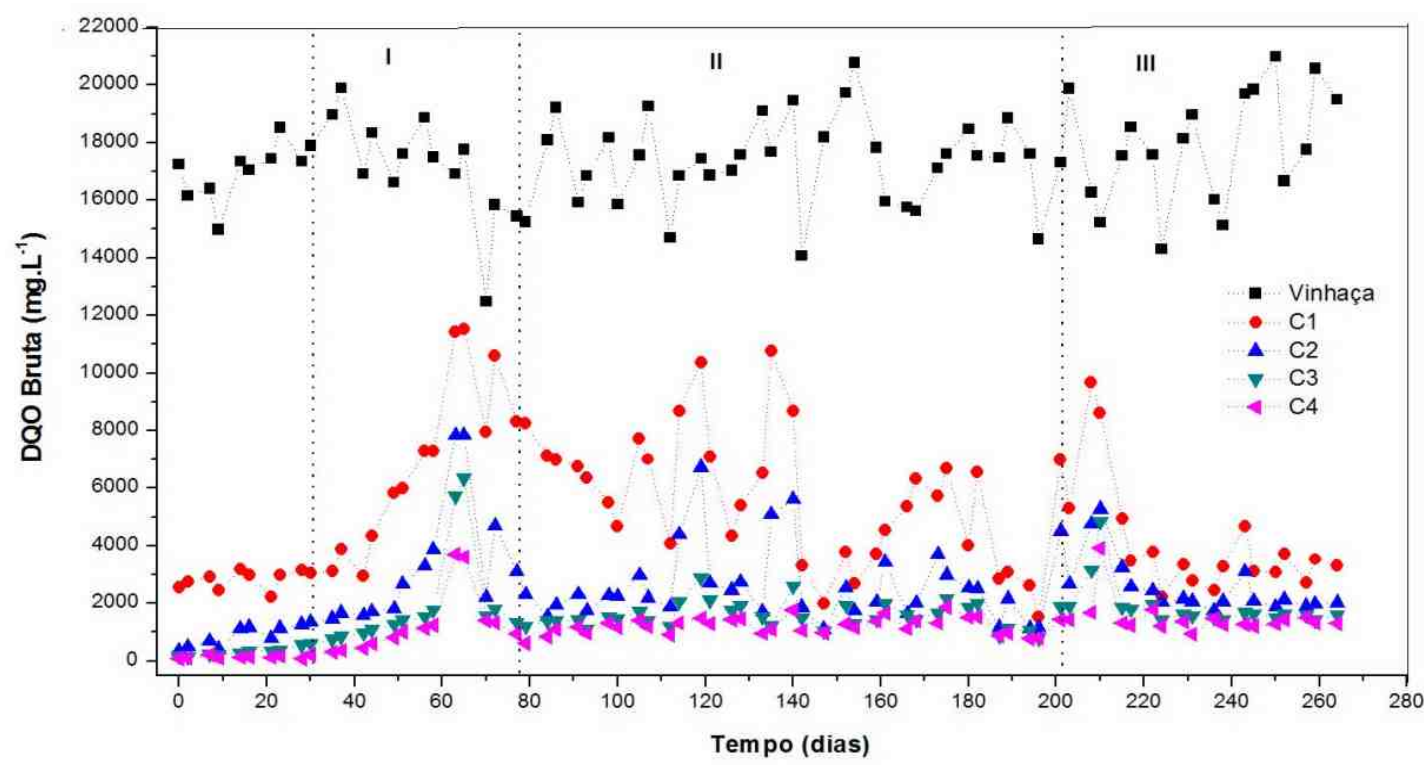

Figura 5.5 - Variação temporal da concentração de $\mathrm{DQO}_{\text {bruta }}$ para a vinhaça e o efluente das câmaras C1, C2, C3 e C4. 


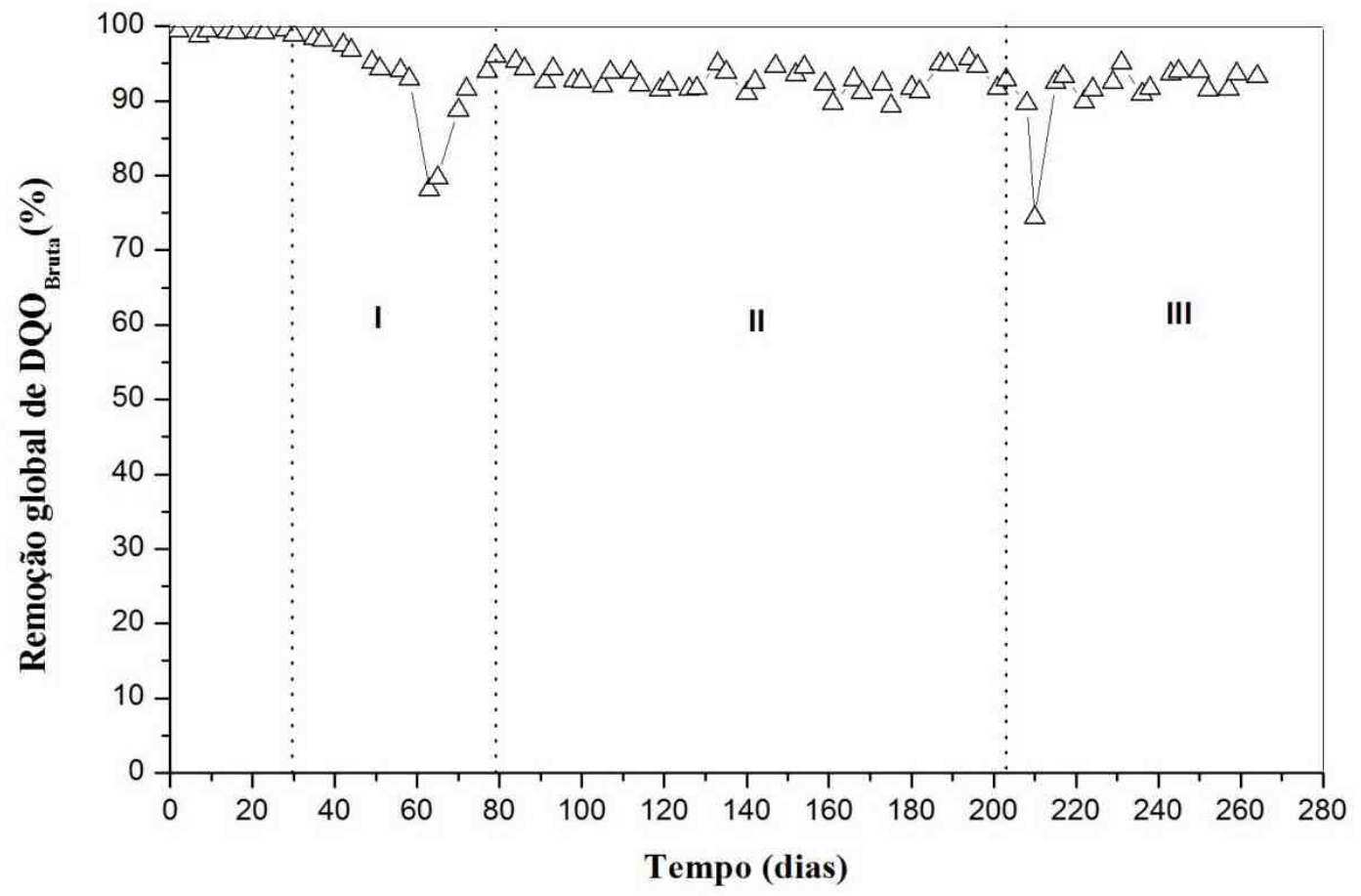

Figura 5.6 - Variação temporal das eficiências de remoção global de $\mathrm{DQO}_{\text {bruta }}$ do RAS.
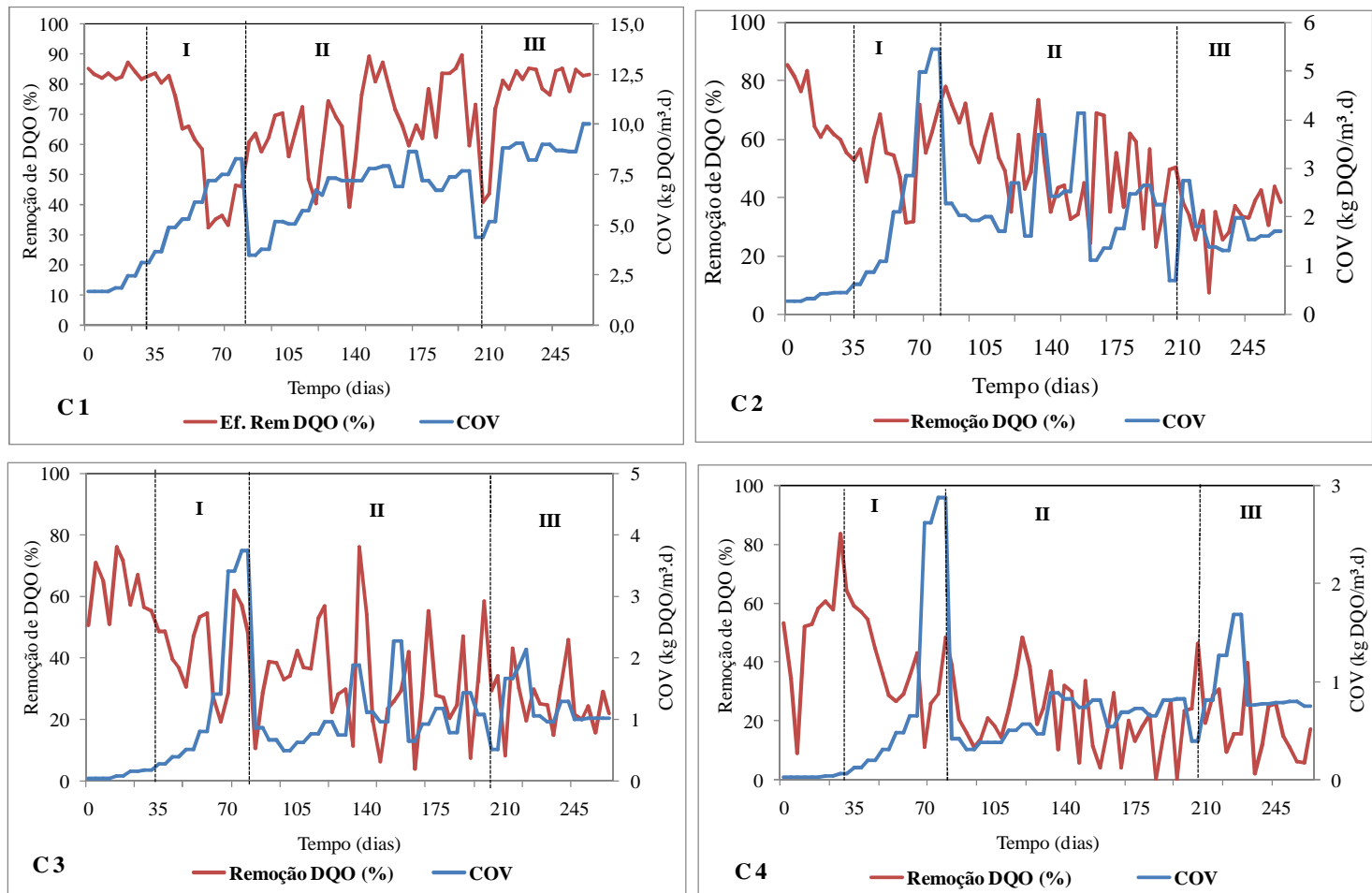

Figura 5.7 - Eficiências de remoção individual de $\mathrm{DQO}_{\text {bruta }}$ em função da $\mathrm{COV}_{\text {individual }}$ para as câmaras C1, C2, C3 e C4. 
No decorrer da operação do reator, a vinhaça afluente as câmaras do RAS apresentou concentração média de DQO de $17.418 \pm 1648,60$ mg. $\mathrm{L}^{-1}$, conseguindo-se valores próximos ao estimado (20.000 mg. $\left.\mathrm{L}^{-1}\right)$. Para as câmaras C1, C2, C3 e C4, obteve-se valores de DQO bruta efluente média de $5.144 \pm 2.508 \mathrm{mg} . \mathrm{L}^{-1}, 2.503 \pm 1.496$ mg. $\mathrm{L}^{-1}, 1.572 \pm 1.018 \mathrm{mg} . \mathrm{L}^{-1}$ e $1.159 \pm 701 \mathrm{mg} . \mathrm{L}^{-1}$, respectivamente (Figura 5.5).

As menores concentrações de DQO efluente para as câmaras do RAS foram observadas para o período de adaptação, como ilustrado na Figura 5.5. Este acontecido deve-se principalmente ao fato que nesta fase, o reator foi submetido a elevados TDH (23 a 40 dias, baixos valores de $\operatorname{COV}_{\text {global }}$ e $\mathrm{COAL}_{\text {global }}$ (Figuras 5.1 a 5.4) e, diluição da vinhaça no tanque de alimentação, para adaptação do lodo de inóculo avícola.

Para as Fases I, II e III foram obtidas concentrações de $\mathrm{DQO}_{\text {bruta }}$ afluente média de $17.033 \pm 1.818$ mg. $\mathrm{L}^{-1}, \quad 17.420 \pm 1.492 \mathrm{mg} . \mathrm{L}^{-1}$ e $17.926 \pm 1.939$ mg.L ${ }^{-1}$ respectivamente, demonstrando homogeneidade das características da vinhaça ao longo da operação do reator.

A imposição de carregamento orgânico a partir da Fase I resultou em oscilações nos valores de residuais de DQO bruta efluente obtida para as câmaras C1, C2, C3 e C4.

Para a Fase I, os valores médios obtidos para as câmaras foram de $7.050 \pm 2.778$ mg.L ${ }^{-1} ; 3.297 \pm 2.065$ mg.L $L^{-1} ; 1.975 \pm 1.689$ mg.L $L^{-1}$ e $1.254 \pm 1.040$ mg.L ${ }^{-1}$ para C1, $\mathrm{C} 2, \mathrm{C} 3$ e $\mathrm{C} 4$, respectivamente.

Na Fase II, observou-se uma menor concentração de DQO efluente para as câmaras do reator RAS de $5.586 \pm 2.239 \mathrm{mg} . \mathrm{L}^{-1} ; 2.618 \pm 1.294 \mathrm{mg} . \mathrm{L}^{-1} ; 1.601 \pm 456$ mg. $\mathrm{L}^{-1}$ e $1.240 \pm 272 \mathrm{mg} . \mathrm{L}^{-1}$ para C1, C2, C3 e C4, respectivamente.

Em relação à última fase da operação (Fase III), com $\operatorname{COV}_{\text {global }}$ entre 1,09 a 2,50 kg DQO $\mathrm{m}^{-3} \cdot \mathrm{d}^{-1}$, os valores médios de concentração de DQO para C1, C2, C3 e C4 
foram da ordem de $4.115 \pm 1.948 \mathrm{mg} . \mathrm{L}^{-1} ; 2.569 \pm 958 \mathrm{mg} . \mathrm{L}^{-1} ; 1.896 \pm 811 \mathrm{mg} . \mathrm{L}^{-1} \mathrm{e}$ $1.500 \pm 613 \mathrm{mg} . \mathrm{L}^{-1}$, respectivamente.

Em termos de eficiência de remoção global de DQO bruta (Figura 5.6), esta foi de 95,4 \% para o período de adaptação, obtendo-se valores de eficiências individuais de remoção para C1, C2, C3 e C4 da ordem de 83,4 \%, 69,4\%, 62,1 \% e 52,5\%, respectivamente (Figura 5.7)

A eficiência média de remoção global de DQO na Fase I foi de 92,5 \% (Figura 5.6), conseguindo-se eficiências de remoções para C1, C2, C3 e C4 (Figura 5.7) da ordem de $68,0 \%, 47,5 \%, 33,0 \%$ e $23,4 \%$, respectivamente.

Quando confrontados os valores de eficiência de remoção global de DQO obtidos das Fases I, II e III (92,5 \%, 92,9 \% e 91,4\%, respectivamente), verifica-se similaridade destes, indicando que, o período de adaptação foi de fundamental importância para a manutenção dos bons resultados da redução de matéria orgânica conseguida ao longo da operação do reator RAS com o aumento gradativo da COV (Figura 5.2), sem a inibição do processo de digestão anaeróbia.

Neste sentido, verificou-se que o reator RAS processando vinhaça, apresentou eficiências satisfatórias na remoção de matéria orgânica na forma de DQO, tendo-se em vista que as maiores parcelas foram obtidas para a primeira câmara $(\mathrm{C} 1)$, muito provavelmente decorrente dos maiores valores de COV e COAL conseguidos ao longo do experimento.

Boopathy e Tilche (1991), utilizando reator compartimentado (ABR) com três câmaras no tratamento de melaço, verificaram que as maiores eficiências de remoção de DQO, foram obtidas para os maiores valores de COV aplicada, da ordem de 4,3 a $28 \mathrm{~kg}$ DQO $\mathrm{m}^{-3} \cdot \mathrm{d}^{-1}$. 
Valores médios de remoção de DQO similares aos obtidos o presente estudo, da ordem de $86 \%$, foram obtidas por Brown (2012) operando reator UASB de $20 \mathrm{~L}$ tratando vinhaça de cana-de-açúcar com COV entre 0,53 a 4,5 $\mathrm{kg}$ DQO m ${ }^{-3} \cdot \mathrm{d}^{-1}$.

Santana Júnior (2013) investigando o tratamento de vinhaça em reator UASB em escala de bancada, obteve valores inferiores na eficiência de remoção de DQO total ao observados neste trabalho, entre 34 a $55 \%$ com COV de 0,15 a $3,50 \mathrm{~kg}$ DQO m ${ }^{-3} \cdot \mathrm{d}^{-1}$.

Robles-Gonzáles (2011) tratando vinhaça em escala de laboratório em reator mesofílico de leito fluidizado com COV de 2,0;2,7; 5,7; 10,7 e 30,4 kg DQO m${ }^{-3} . \mathrm{d}^{-1}$, obteve eficiência de remoção de DQO entre de 61,5 a 84,8\%, observando redução na eficiência da remoção de DQO com COV próximas à $30,4 \mathrm{~kg}$ DQO m $\mathrm{m}^{-3} \cdot \mathrm{d}^{-1}$.

Na Figura 5.8 a 5.10, são apresentados os valores relativos às concentrações de DQO filtrada, eficiências de remoção individual e global, respectivamente.

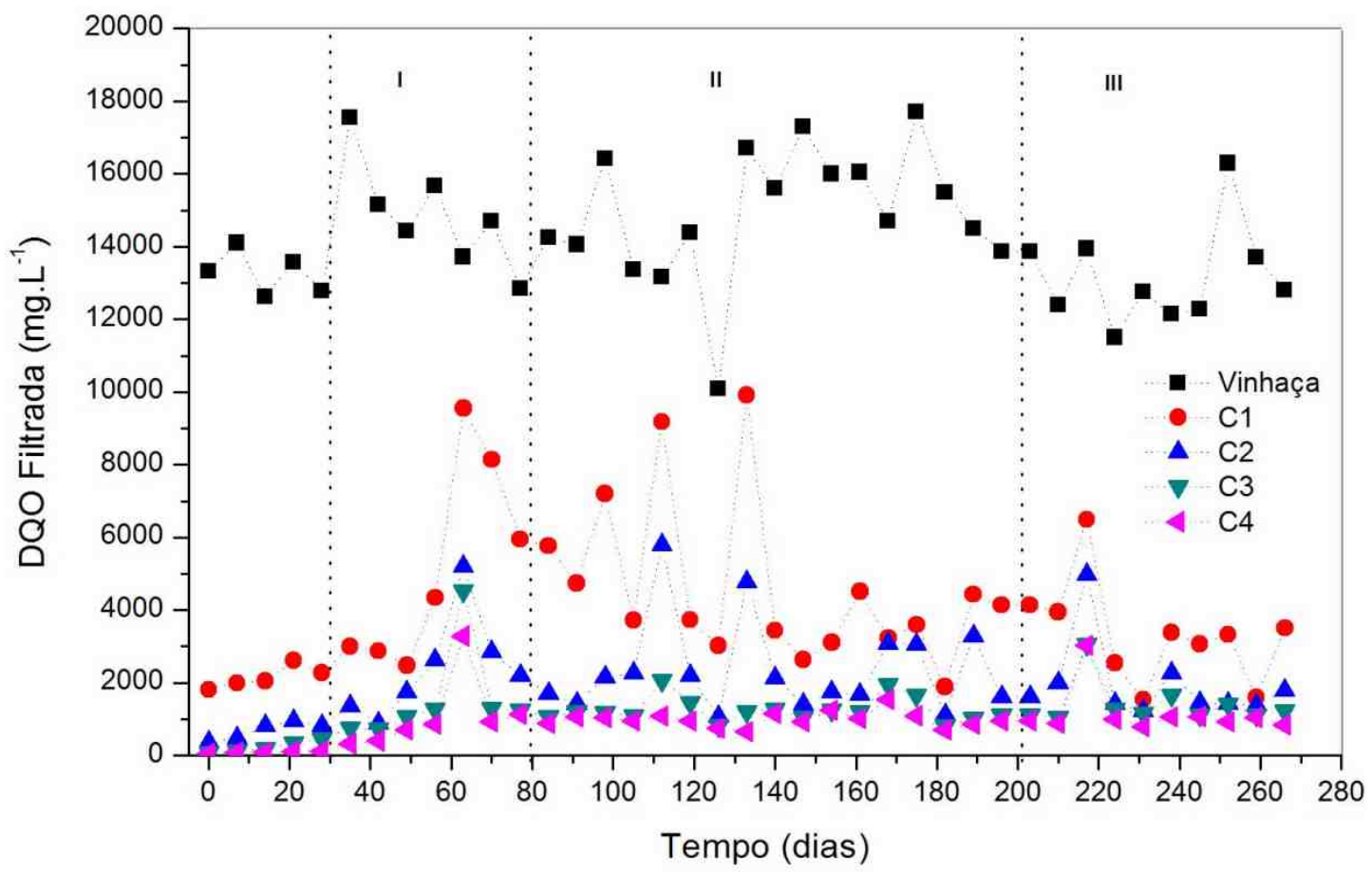

Figura 5.8 - Variação temporal da concentração de DQO $_{\text {filtrada }}$ para a vinhaça e o efluente das câmaras C1, C2, C3 e C4. 


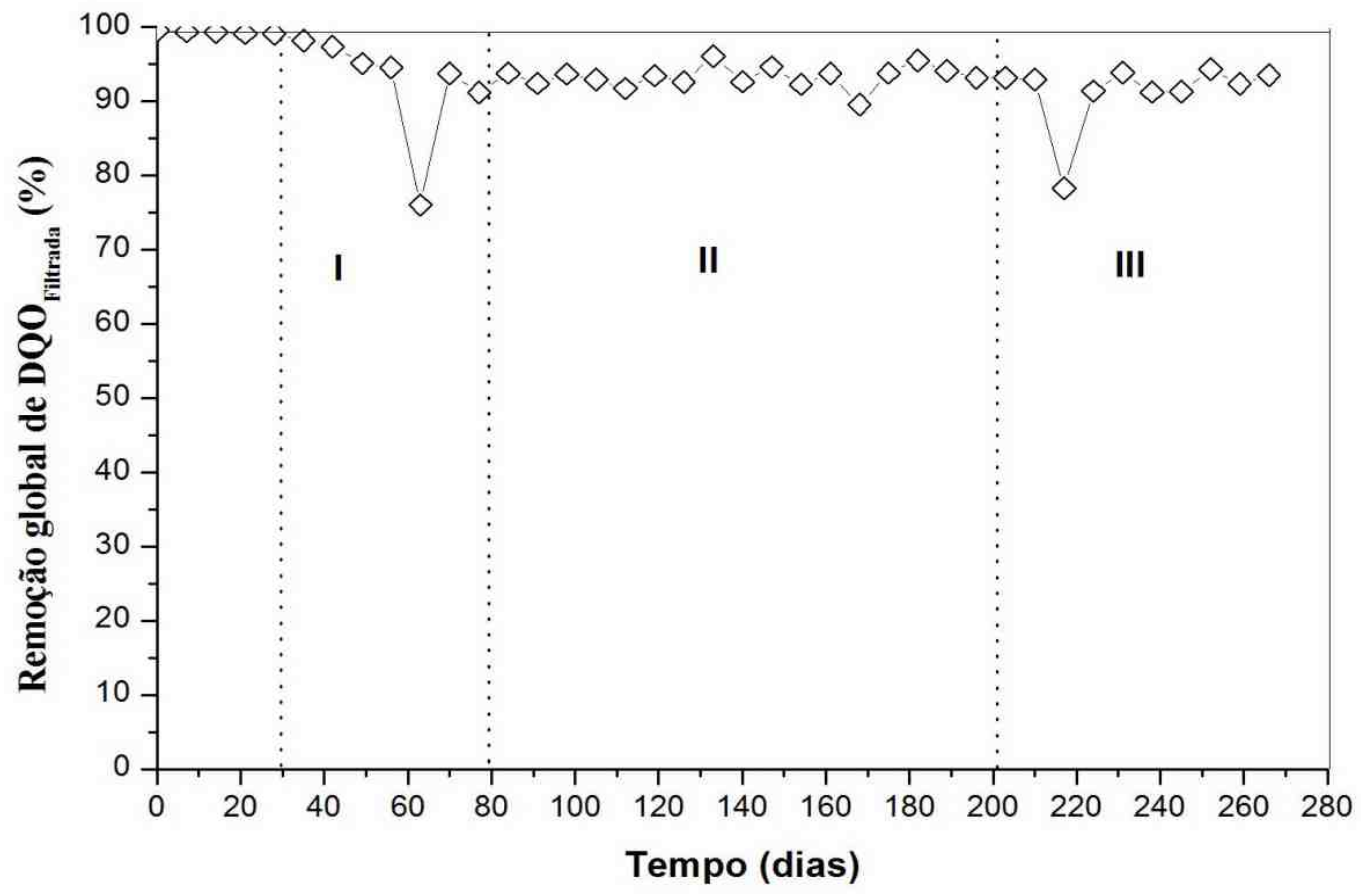

Figura 5.9- Variação temporal das eficiências de remoção global de $\mathrm{DQO}_{\text {Filtrada }}$ durante a operação do RAS.
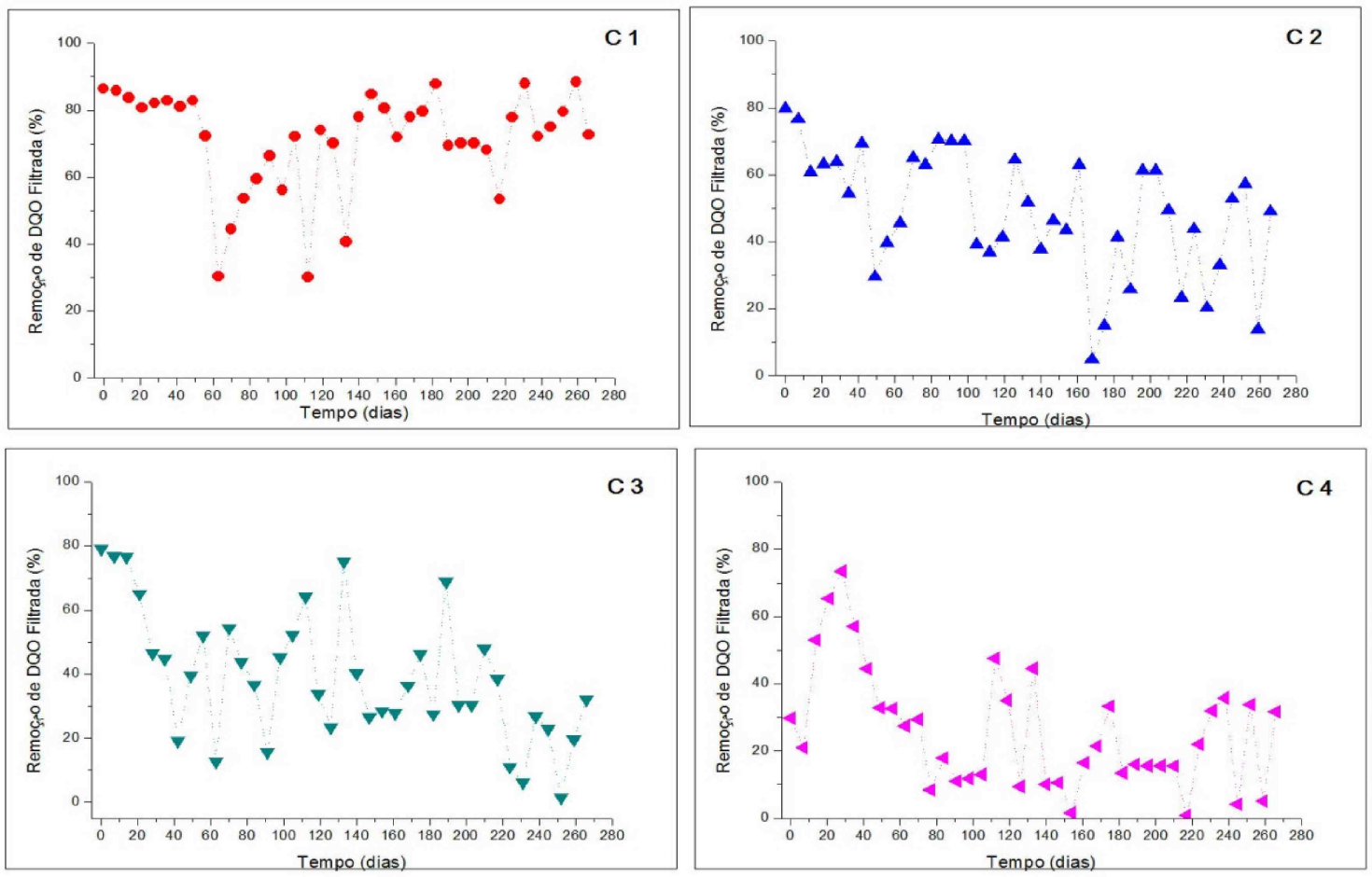

Figura 5.10 - Eficiências de remoção individual de $\mathrm{DQO}_{\text {Filtrada }}$ para as câmaras C1, C2, C3 e C4. 
Os valores de concentração de DQO filtrada obedeceram ao comportamento temporal da DQO bruta, conforme ilustrado na Figura 5.8. Analisando os dados da referida Figura 5.8, constata-se que os valores médios de DQO filtrada para a vinhaça e os efluentes das câmaras C1, C2, C3 e C4 na fase de adaptação foram de $13.274 \pm$ $603,59 \mathrm{mg} / \mathrm{L}, 2.148,6 \pm 306,55 \mathrm{mg} / \mathrm{L}, 683,9 \pm 253,44 \mathrm{mg} / \mathrm{L}, 229,3 \pm 154,12$ e $91,9 \pm$ $25,86 \mathrm{mg} / \mathrm{L}$, respectivamente.

Para as Fases I, II e III obteve-se maiores concentrações residuais de DQO ${ }_{\text {filtrada }}$ decorrente a imposição de carregamento orgânico aplicado nestas fases.

Conforme a Figura 5.9, na etapa de adaptação do inóculo, a eficiência média de remoção de matéria orgânica, medida como DQO filtrada foi de 99,3\%. Quanto às demais fases da operação (I, II e III), obteve-se valores médios de remoção de DQO $_{\text {filtrada }}$ acima de $90 \%$.

Nas Figuras 5.11 e 5.12 são apresentados os valores das concentrações de carboidratos e suas respectivas eficiências de remoção para as câmaras do RAS.

Os resultados obtidos para as eficiências de remoção de carboidratos, durante todo o período do experimento (Figura 8.12) corroboram para o bom desempenho apresentado pelo RAS na remoção de matéria orgânica, como verificado anteriormente para o parâmetro de DQO.

As concentrações de carboidratos observadas para a vinhaça e o efluente da C4 na fase de adaptação (Figura 5.12), foram de 2.175,95 e 5,76 mg/L, respectivamente, correspondendo a um percentual médio de remoção de 99,7 $\pm 0,22 \%$. Para as fases seguintes (I, II e III) os valores de carboidratos ficaram em torno de 1905,43 e 86,48 $\mathrm{mg} / \mathrm{L}$ para o afluente e o efluente da $\mathrm{C} 4$, respectivamente, correspondendo a um percentual de remoção global igual a 95,5 $\pm 2,73 \%$. 


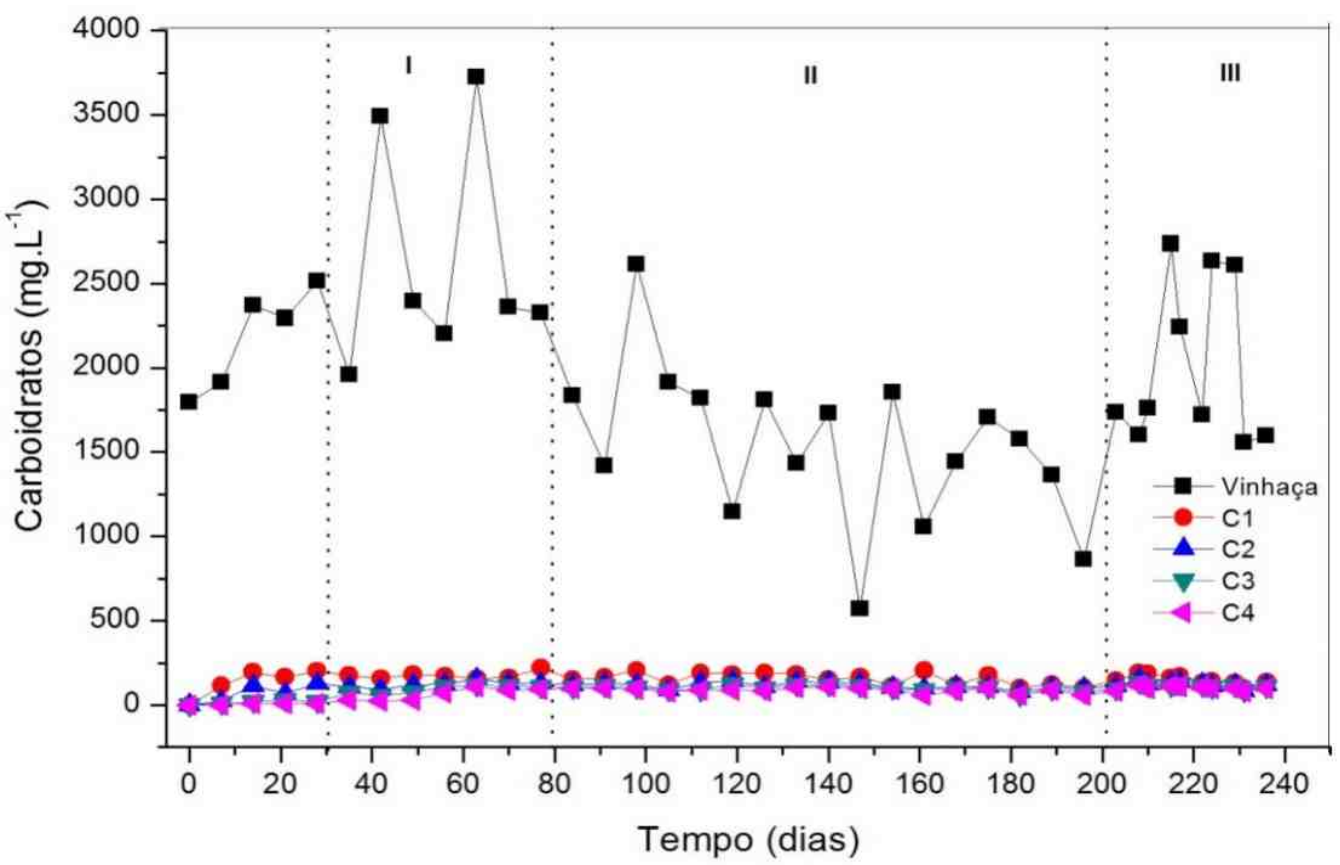

Figura 5.11 - Variação temporal da concentração de carboidratos para a vinhaça e o efluente das câmaras do RAS.
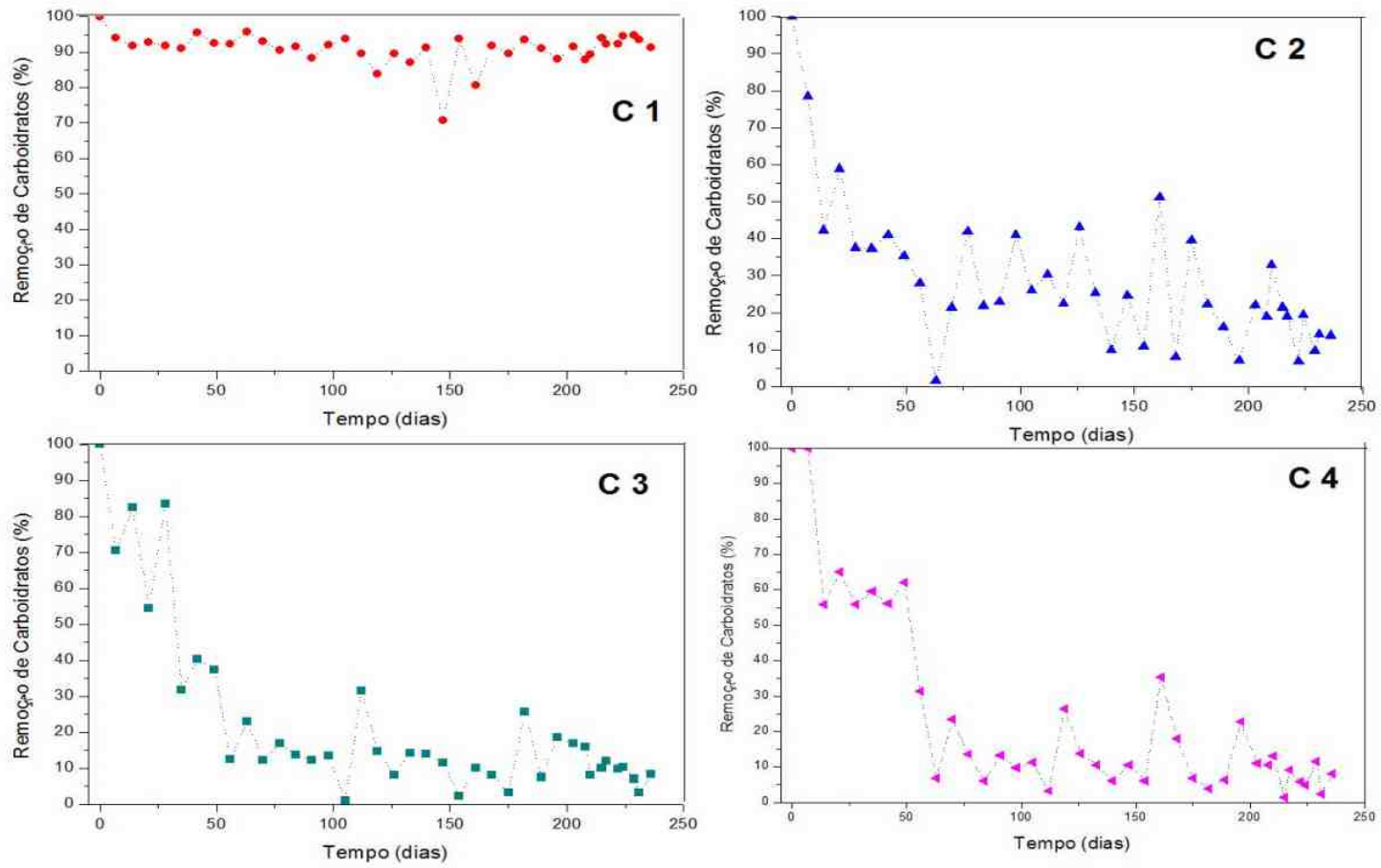

Figura 5.12 - Eficiências de remoção individual de carboidratos para as câmaras C1, $\mathrm{C} 2, \mathrm{C} 3$ e $\mathrm{C} 4$. 
Como observado para a DQO, a maior remoção de carboidratos foram conseguidas já na câmara $\mathrm{C} 1$, em função desta câmara deter as maiores COV e COAL aplicadas, oscilando entre 1,67 a 10,40 kg DQO $\mathrm{m}^{-3} \cdot \mathrm{d}^{-1}$ e 0,11 a $0,67 \mathrm{~kg}$ DQO/kg STV.d, respectivamente, e da boa aclimatação da biomassa microbiana à vinhaça.

Os bons resultados de remoção de carboidratos podem ser justificados pela abundância relativa de microrganismos pertencentes ao gênero T78, os quais são consumidores de carboidratos, identificados no sequenciamento filogenético das amostras das câmaras do RAS, apresentados no item 5.1.4.3.

Nas Figuras 5.13 a 5.17 são apresentados os valores de alcalinidade, valores médios de alcalinidade, a concentração de ácidos voláteis totais (AVT), os valores médios de AVT e a variação do pH, obtidos durante a operação do reator RAS.

Os parâmetros de alcalinidade, ácidos voláteis e pH estão estritamente relacionados entre si podendo influenciar igualmente o processo de digestão anaeróbia de águas residuárias. 


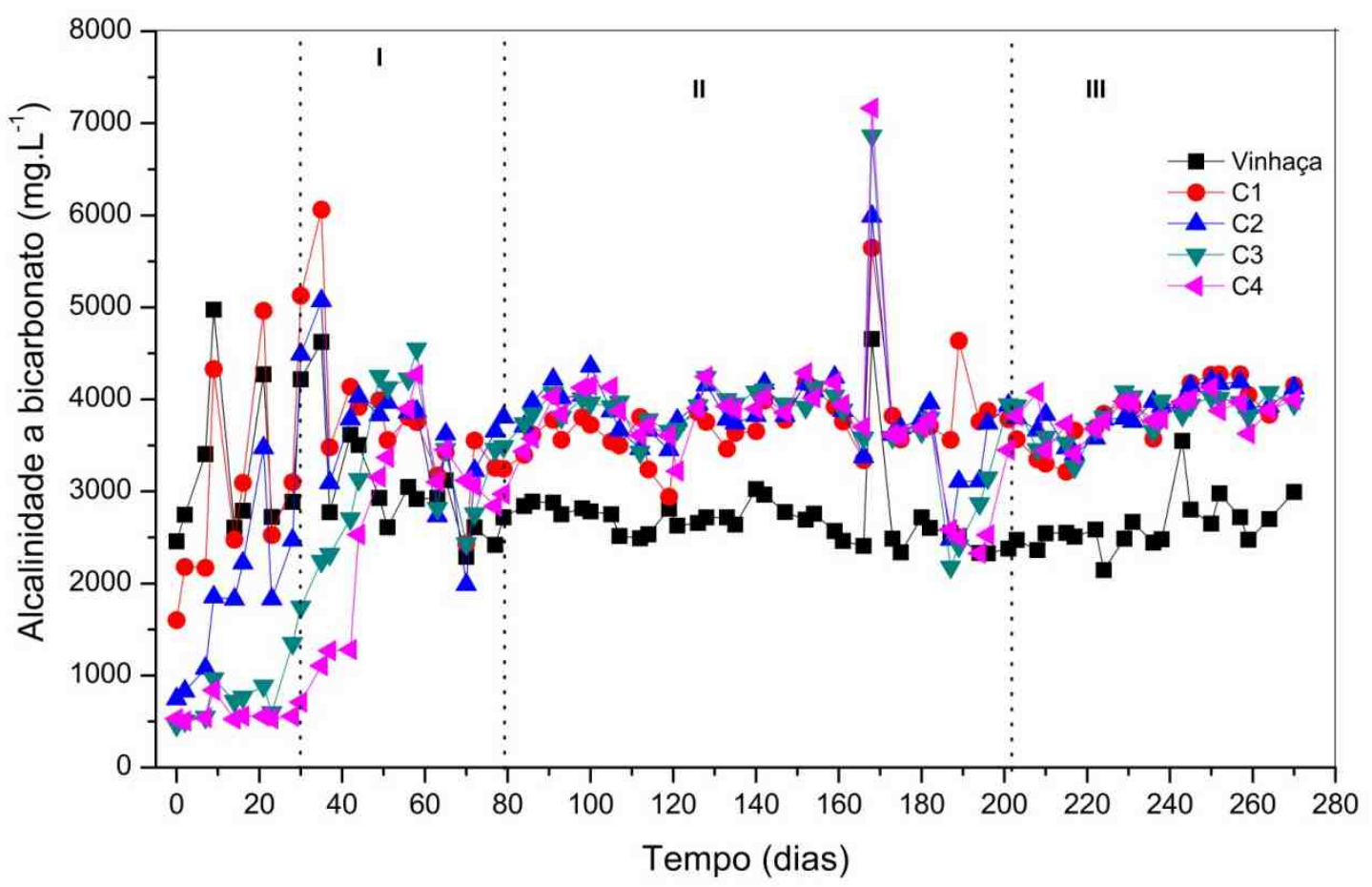

Figura 5.13 - Variação temporal de alcalinidade para a vinhaça e o efluente das câmaras do RAS.

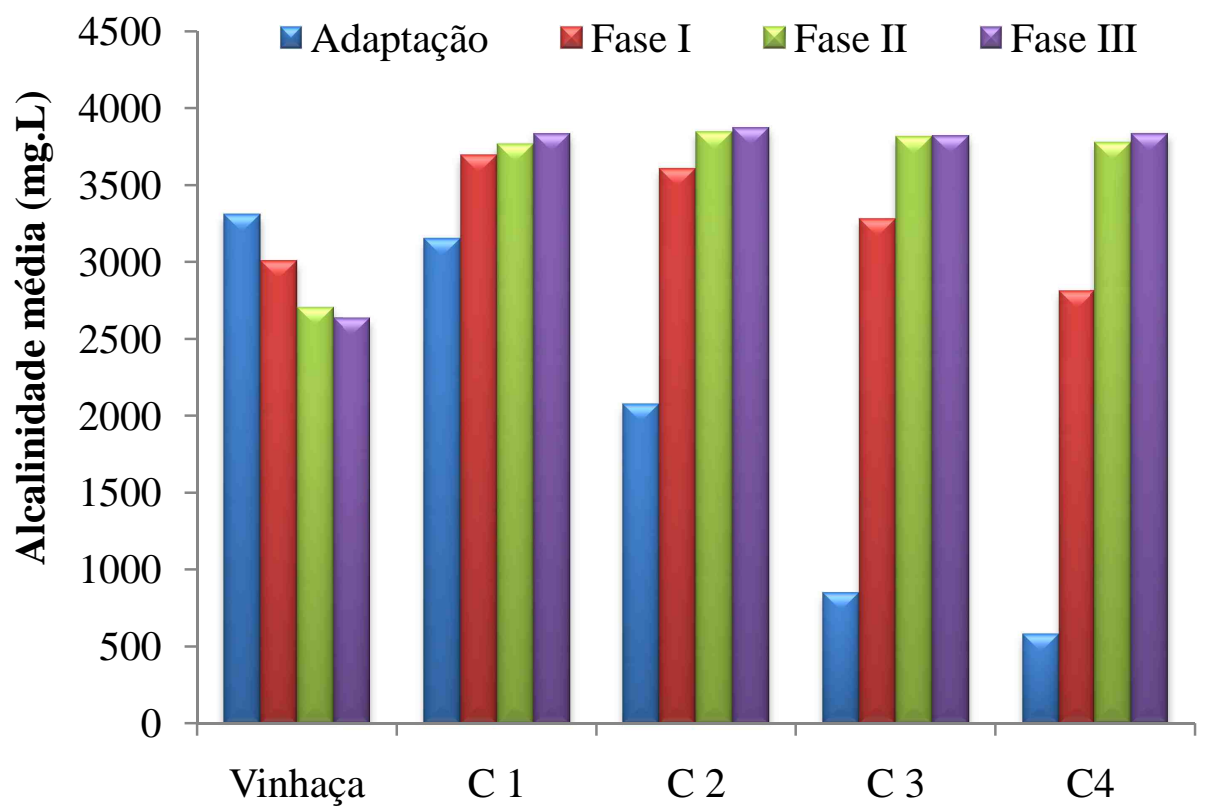

Figura 5.14 - Valores médios de alcalinidade a bicarbonato para a vinhaça e o efluente das câmaras do RAS. 


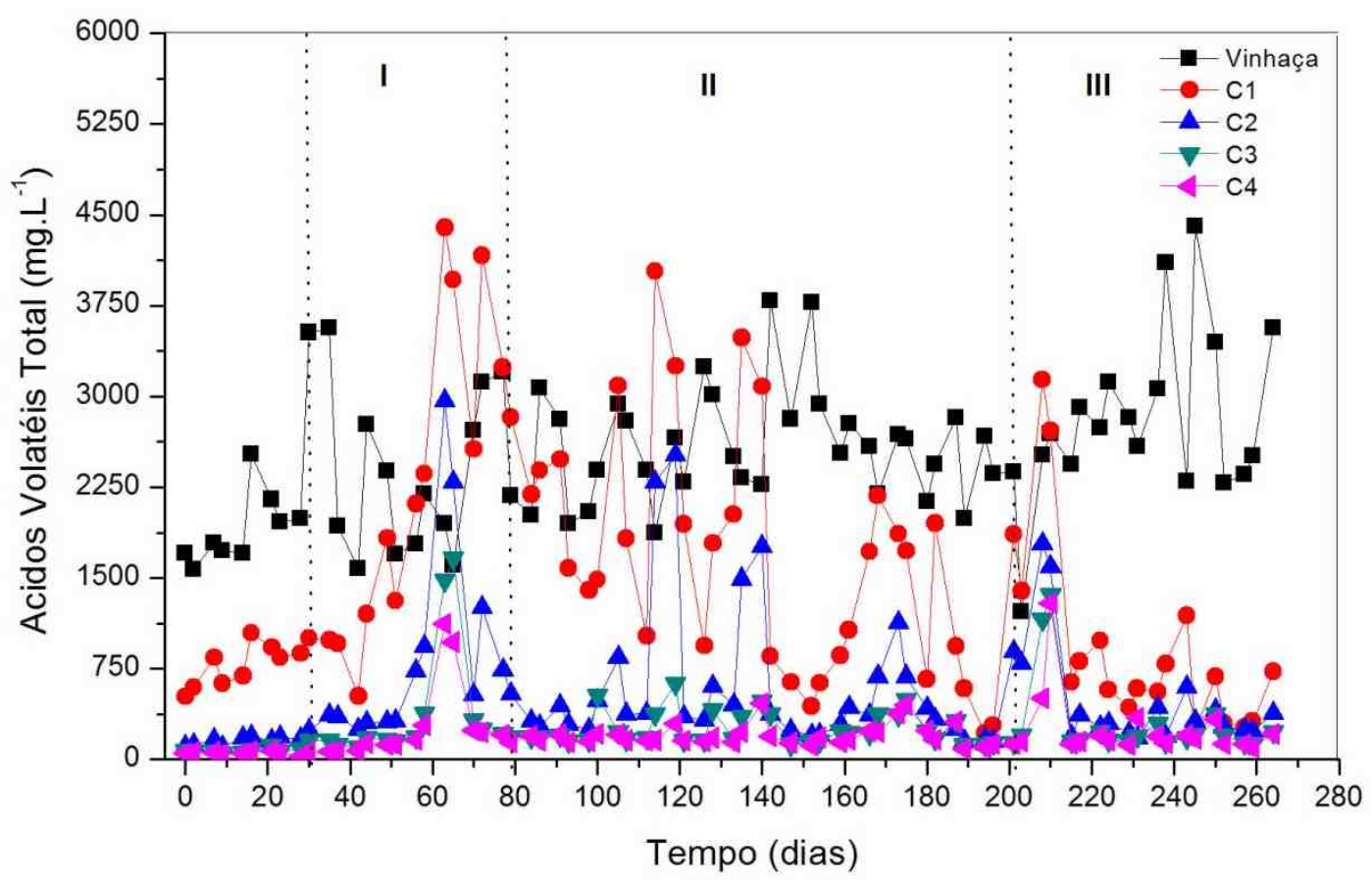

Figura 5.15 - Variação temporal das concentrações de ácidos voláteis totais (AVT) para a vinhaça e os efluentes das câmaras do RAS.

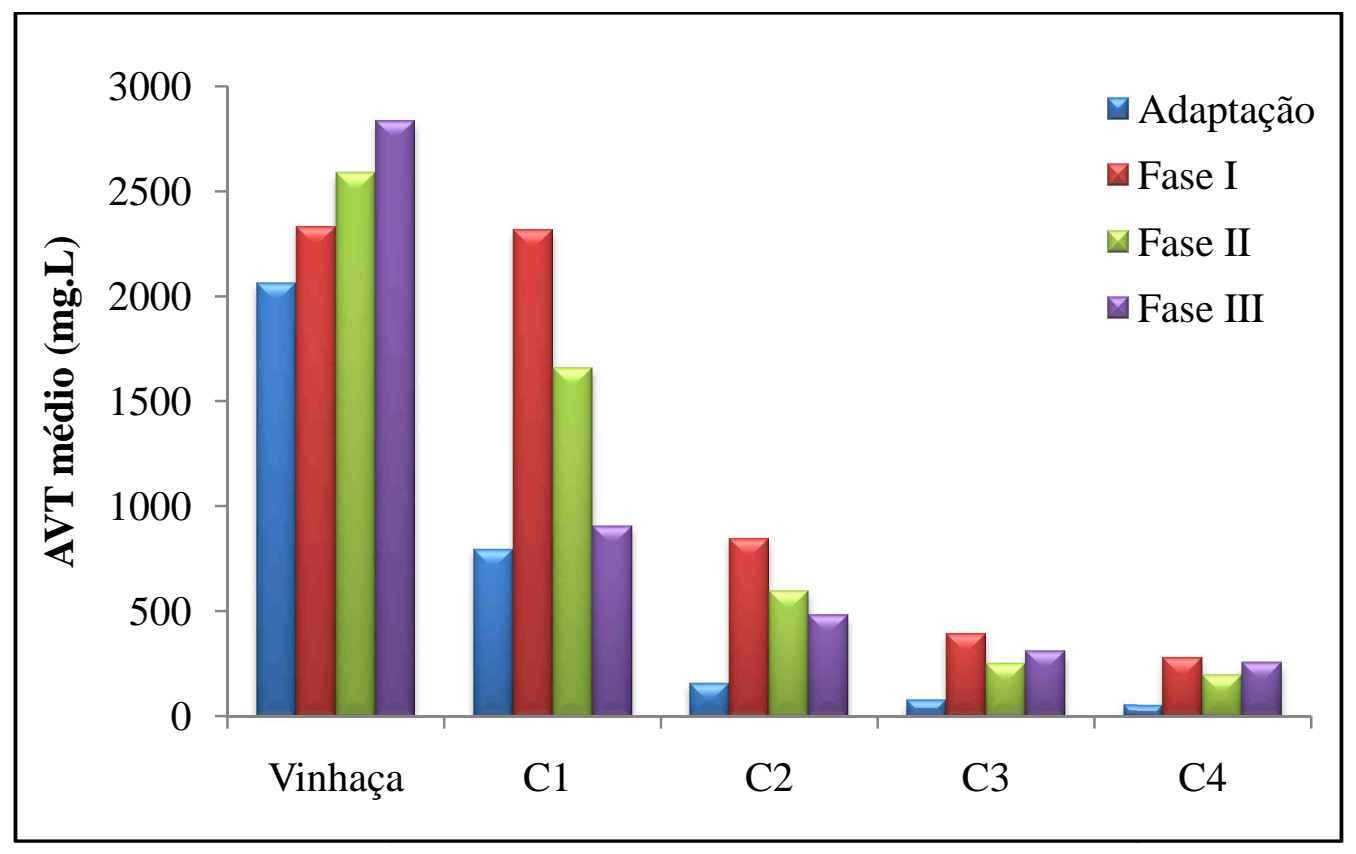

Figura 5.16 - Concentração média de AVT para a vinhaça e o efluente das câmaras do RAS. 


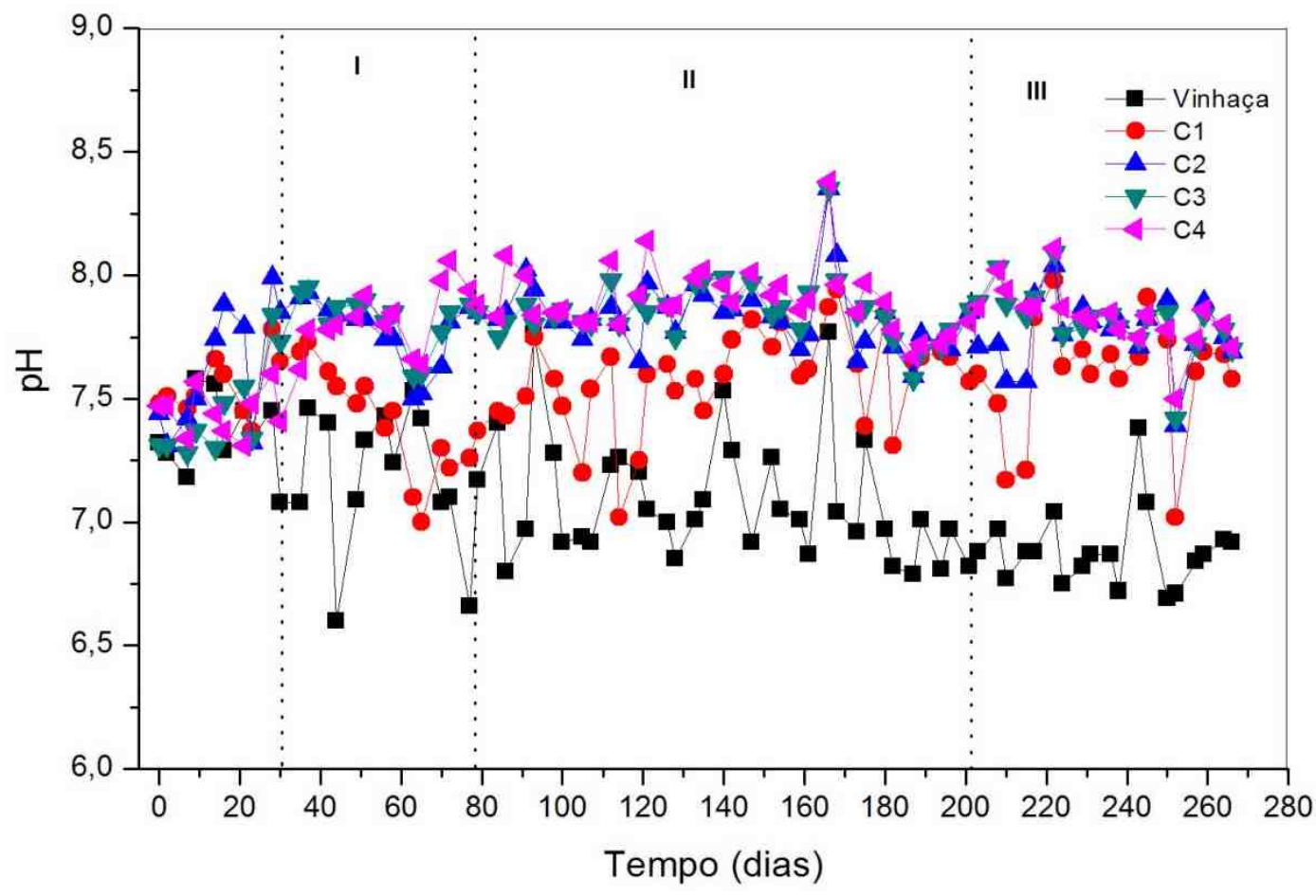

Figura 5.17 - Variação temporal dos valores de pH para a vinhaça e o efluente das câmaras do RAS.

Analisando os dados da Figura 5.13 observa-se que, os valores de alcalinidade provenientes do efluente das câmaras do reator para as Fases I, II e III, foram em média superiores aos valores apresentados pela vinhaça bruta, demonstrando boa capacidade do RAS no tamponamento dos ácidos intermediários gerados no processo de digestão, em virtude da sua compartimentação.

Constata-se, que o aumento gradativo da carga orgânica verificado nas Fases I, II e III, favoreceu a geração de alcalinidade em todas as câmaras do reator. Para as Fases II e III, observa-se similaridade nos valores médios de alcalinidade para C1, C2, C3 e C4 (Figura 5.14) como resultado das $\mathrm{COV}_{\text {individual }} \mathrm{COAL}_{\text {individual }}$ obtidas ao final de cada fase (Figuras 5.1 e 5.3).

$\mathrm{Na}$ fase inicial da operação do reator (período de adaptação), foram observadas as menores concentrações de alcalinidade (Figura 5.14), decorrentes dos baixos valores de 
carregamento orgânico global aplicado nesta fase $\left(0,42\right.$ a $0,78 \mathrm{~kg}$ DQO $\left.\mathrm{m}^{-3} \cdot \mathrm{d}^{-1}\right)$, e das concentrações superiores de ácidos voláteis da vinhaça bruta, observadas nesse período (Figura 5.15).

A alcalinidade total média da vinhaça bruta ao longo da operação foi de $2.749 \pm$ 535,20 mg/L, constatando concentrações médias maiores para as câmaras C1, C2, C3 e $\mathrm{C} 4$ da ordem de $3.774 \pm 663,40 \mathrm{mg} / \mathrm{L} ; 3.807 \pm 852,14 \mathrm{mg} / \mathrm{L} ; 3.706 \pm 244,03 \mathrm{mg} / \mathrm{L}$ e $3.594 \pm 262,84 \mathrm{mg} / \mathrm{L}$, respectivamente.

Segundo Grady Júnior e Lim (1980) para a maioria dos casos práticos, uma alcalinidade total compreendida entre 2.500 e $5.000 \mathrm{mg} \mathrm{CaCO}_{3} \mathrm{~L}^{-1}$ é suficiente para se obter um adequado poder tampão na unidade de tratamento. No entanto, tal constatação deverá considerar o tipo de água residuária.

Metcalf e Eddy (2003) fizeram afirmação semelhante, de que para que o processo de digestão anaeróbia ocorra de forma satisfatória, a alcalinidade deverá situar-se na faixa de 1.000 a $5.000 \mathrm{mg} \mathrm{CaCO}_{3} / \mathrm{L}$.

De forma geral, a alcalinidade média efluente proveniente das câmaras mantevese superior à vinhaça (Figura 5.14), indicando o equilíbrio e adaptação dos consórcios microbianos presente nas câmaras do RAS na geração e consumo de ácidos voláteis totais (Figura 5.15).

O tamponamento da vinhaça de cana-de-açúcar com solução de bicarbonato de sódio (0,5 $\left.\mathrm{g} \mathrm{NaHCO}_{3} / \mathrm{g} \mathrm{DQO}\right)$, foi fundamental para o processo de degradação anaeróbia ocorrido nas quatro câmaras, tendo em vista a adequação do pH (entre 6,6 e 7,7) e posterior neutralização dos ácidos totais produzidos.

Essa manobra operacional é justificável, pois, embora os processos anaeróbios gerem alcalinidade na conversão de ácidos voláteis intermediários com geração de cátion como produto final, a adição de álcali é extremamente recomendada para a 
digestão anaeróbia com alta taxa de carboidratos (Chernicharo, 1997), como verificado neste estudo.

Harada et al. (1996) também adicionaram bicarbonato de sódio como agente tampão na mesma dosagem empregada neste estudo (0,5 $\mathrm{g} \mathrm{NaHCO}_{3} / \mathrm{g}$ DQO) para a manutenção do pH da vinhaça em torno de 7,3 em um reator UASB, obtendo eficiências de remoção de DQO na faixa de $39 \%$ a $67 \%$.

Siqueira et al. (2008) obtiveram condições favoráveis de estabilidade na geração de alcalinidade e consumo de ácidos voláteis, com eficiências de remoção de DQO da ordem de $51 \%$ a $70 \%$, em um reator RALF com COV aplicada de 3,3 a 26,2 kg DQO $\mathrm{m}^{-3} \cdot \mathrm{d}^{-1}$, utilizando o dobro da dosagem de bicarbonato de sódio utilizada neste estudo (1,0 $\left.\mathrm{g} \mathrm{NaHCO}_{3} / \mathrm{g} \mathrm{DQO}\right)$, para o tamponamento e correção do $\mathrm{pH}$ da vinhaça.

Mesmo constatando estabilidade do reator por meio da geração de alcalinidade, observam-se oscilações nas concentrações de ácidos voláteis totais, com picos verificados ao longo das fases de operação (Figura 5.15).

As concentrações de ácidos voláteis da vinhaça utilizada na alimentação do reator RAS para as Fases I, II e III foram de $2.334 \pm 620,43 \mathrm{mg} / \mathrm{L}, 2591 \pm 451,11 \mathrm{mg} / \mathrm{L}$ e 2837 $\pm 707,84 \mathrm{mg} / \mathrm{L}$, respectivamente. Os maiores valores de ácidos voláteis foram verificados para $\mathrm{C} 1$, em ambas as fases da operação do RAS, como ilustrado nas Figuras 5.15 e 5.16 .

Na Fase I obtiveram-se as maiores concentrações médias de AVT para C1, C2, C3

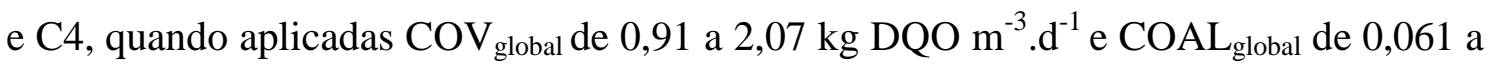
0,138 kg DQO/kg STV.d ${ }^{-1}$, quando comparados as Fase II e III.

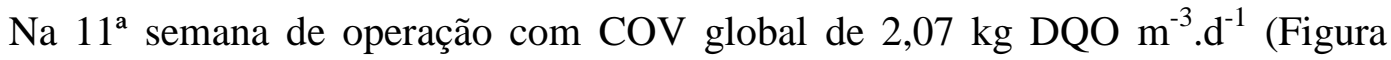
5.1), a concentração de ácidos voláteis em $\mathrm{C} 1\left(\mathrm{COV}\right.$ de $\left.8,27 \mathrm{~kg} \mathrm{DQO} \mathrm{m}^{-3} \cdot \mathrm{d}^{-1}\right)$ que era de 4.395,7 mg/L, ultrapassou em $20 \%$ o valor obtido da vinhaça $(1.778 \mathrm{mg} / \mathrm{L})$, com 
concomitante acúmulo de ácidos em C2, C3 e C4, indicando desequilíbrio na produção de ácidos no processo de degradação da vinhaça em virtude da carga orgânica aplicada nesta câmara em comparação com as demais.

Como estratégia operacional corretiva, na $12^{\mathrm{a}}$ semana o incremento na vazão de alimentação foi reduzido em $50 \%$, verificando a rápida estabilidade operacional do RAS na $13^{\mathrm{a}}$ semana, com concentrações de AVT efluente de $2.565 ; 536,15 ; 327,02$ mg/L e 241,08 mg/L em C1, C2, C3 C4, respectivamente.

Novamente, observou-se na $20^{\mathrm{a}}$ e $29^{\mathrm{a}}$ semana (Fase II), o aumento na concentração de ácidos em C1 ultrapassando em mais de $20 \%$ o valor obtido para a vinhaça, ocorrendo o acúmulo de AVT em C2, C3 e C4. Os valores de $\mathrm{COV}_{\text {individual }}$ observados para este período eram de 7,18; 3,70; 1,87 e $0,88 \mathrm{~kg}$ DQO m${ }^{-3} \cdot \mathrm{d}^{-1}$ em C1, $\mathrm{C} 2, \mathrm{C} 3$ e $\mathrm{C} 4$, respectivamente.

Entretanto, nas Fases II e III foram observados os maiores consumos de ácidos voláteis, em termos médios, conforme ilustrado na Figura 5.16. O que se observa é que quando elevados os valores de carga orgânica ( $\mathrm{COV}_{\text {individual }}$ e $\left.\mathrm{COAL}_{\text {individual }}\right)$, principalmente em $\mathrm{C} 1$, houve uma maior produção de ácidos neste compartimento, sendo essa concentração excedente acumulada, e encaminhada posteriormente para as câmaras subsequentes, alterando o equilíbrio das reações bioquímicas do processo anaeróbio e consequente desbalanceamento global do consumo de ácidos (Ripley et al., 1986).

De modo geral, constata-se que mesmo em condições de acúmulo de ácidos voláteis, como resultado da aplicação de maiores $\mathrm{COV}$ nas primeiras câmaras $(\mathrm{C} 1 \mathrm{e}$ C2), a compartimentação do reator favoreceu a auto-regulação das concentrações adversas, sendo o excesso de ácidos sintetizados nas câmaras posteriores (C3 e C4). 
Durante todo o período de monitoramento das Fases I, II e III, mesmo quando ocorreu o acúmulo de ácidos voláteis, os valores de $\mathrm{pH}$ nas câmaras não foram inferiores a 6,5 (Figura 5.17), valor este considerado limitante para a garantia da atividade metanogênica (Speece, 1992).

Os valores de $\mathrm{pH}$ da vinhaça (afluente) durante todo o período operacional do reator oscilaram entre 6,60 a 7,70. Em relação aos valores obtidos para as quatro câmaras, estes oscilaram na faixa de 7,00 a 8,38 , indicando o equilíbrio das reações bioquímicas do consumo de ácidos voláteis com consequente geração de alcalinidade, por meio da especialização dos consórcios microbianos presentes nas câmaras do reator.

Verificou-se que mesmo após os problemas de obstrução das câmaras do reator, com consequente redução das cargas orgânicas aplicadas, os valores de pH permaneceram dentro da faixa de neutralidade adequada para o processo anaeróbio, não necessitando de maiores ajustes no tamponamento dos efluentes provenientes da $\mathrm{C} 1, \mathrm{C} 2$ e C3.

Os valores dos parâmetros de sólidos suspensos totais (SST), sólidos suspensos fixos (SST) e sólidos suspensos voláteis (SSV), obtidos do monitoramento do reator, são apresentados nas Figuras 5.18 . 


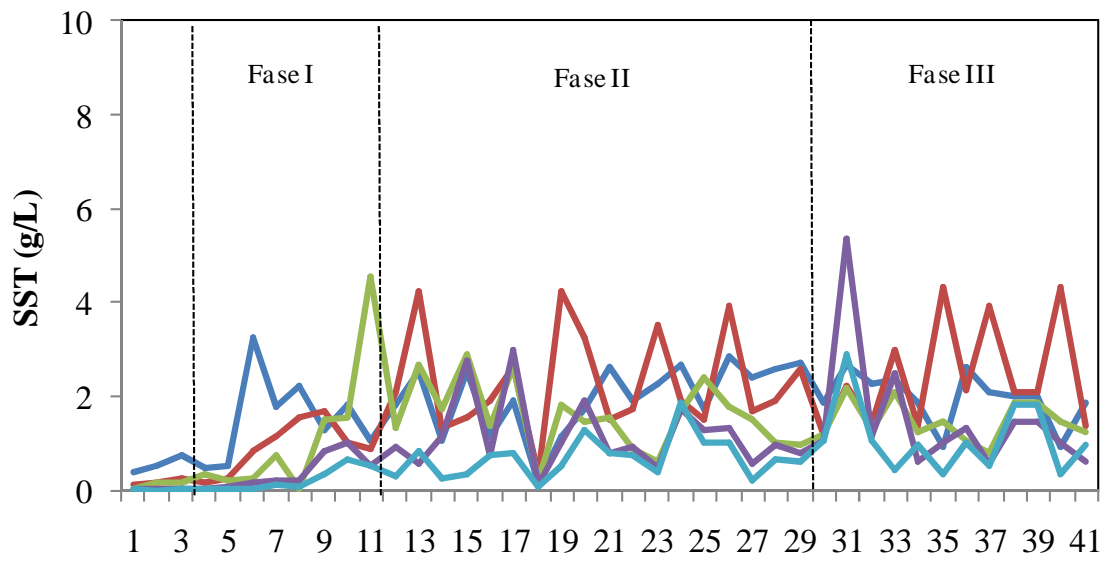

Tempo (semanas)

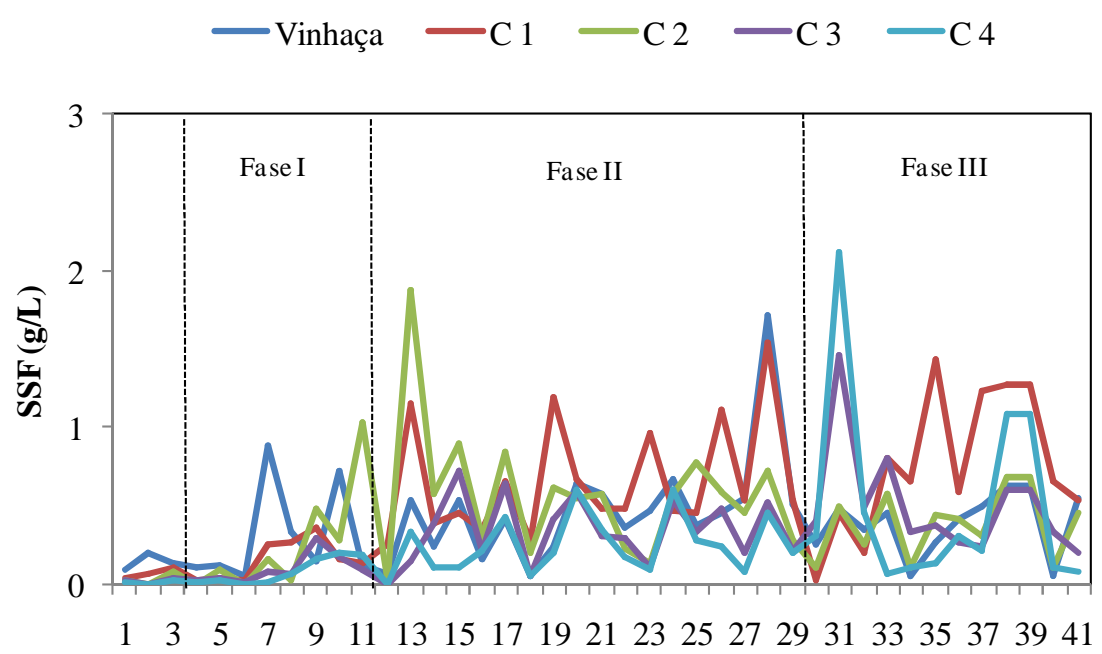

Tempo (semanas)

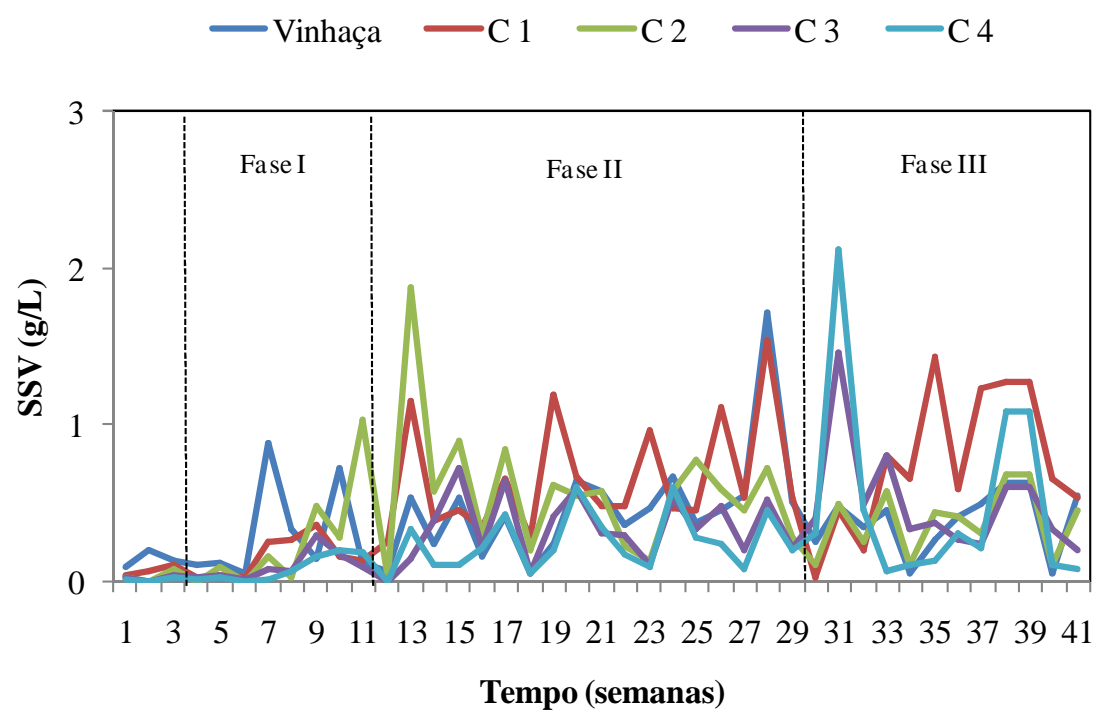

- Vinhaça $-\mathrm{C} 1-\mathrm{C} 2-\mathrm{C} 3-\mathrm{C} 4$

Figura 5.18 - Variação temporal de sólidos suspensos totais (SST), sólidos suspensos fixos (SSF) e sólidos suspensos voláteis (SSV) ao longo da operação do reator RAS. 
Observa-se a partir da Figura 5.18 que houve variações na concentração de sólidos para as diferentes câmaras do reator, em função do aumento da COV aplicada ao longo das fases da operação.

Nos períodos compreendidos entre a $11^{\mathrm{a}}$ e $29^{\mathrm{a}}$ semana, foi observado perda de sólidos do sistema, principalmente em $\mathrm{C} 1\left(\mathrm{COV}_{\text {individual }}\right.$ aplicado de 8,27 e 7,67 kg $\mathrm{DQO} / \mathrm{m}^{-3} \cdot \mathrm{d}^{-1}$, respectivamente), provavelmente decorrente ao arraste de biomassa pelas bolhas de biogás formadas no interior do reator, em detrimento ao entupimento do RAS neste período de operação, como já comentado.

A vinhaça (afluente) apresentou concentrações de sólidos totais e sólidos voláteis ligeiramente maiores em relação ao efluente das câmaras ao longo de todo o período de operação, demonstrando capacidade do RAS na retenção de sólidos.

As concentrações médias de sólidos para a vinhaça ao longo do monitoramento do reator foram de 1,40 $\pm 0,84 \mathrm{~g} / \mathrm{L}(\mathrm{SST}), 0,27 \pm 0,25 \mathrm{~g} / \mathrm{L}(\mathrm{SSF})$ e $1,14 \pm 0,79 \mathrm{~g} / \mathrm{L}(\mathrm{SSV})$

Os menores teores de sólidos foram obtidos para as últimas câmaras (C3 e C4), tendo em vista que a grande parcela do material particulado que adentra o reator fica retida nos primeiros compartimentos $(\mathrm{C} 1$ e $\mathrm{C} 2)$.

A perda de biomassa em termos de SSV (Figura 5.18) verificada no transcorrer das fases de operação em C1, C2, C3 e C4, foi relativamente baixa quando comparadas as perdas de sólidos totais.

A colocação de separadores na parte superior de cada câmara de certa forma contribuiu para a redução do arraste e perda de sólidos, verificada inicialmente no tratamento da vinhaça.

Desta forma, o reator RAS demonstrou ser passível de utilização para o processamento de águas residuárias com teor de material particulado em termos de sólidos, como é o caso da vinhaça de cana-de-açúcar. 


\subsubsection{Potencial de produção de metano e composição do biogás}

Os dados referentes ao monitoramento da produção de metano teórica calculada para as câmaras C1, C2, C3 e C4 no decorrer do período de operação do reator nas Fases I, II e III, são apresentados na Figura 5.20.

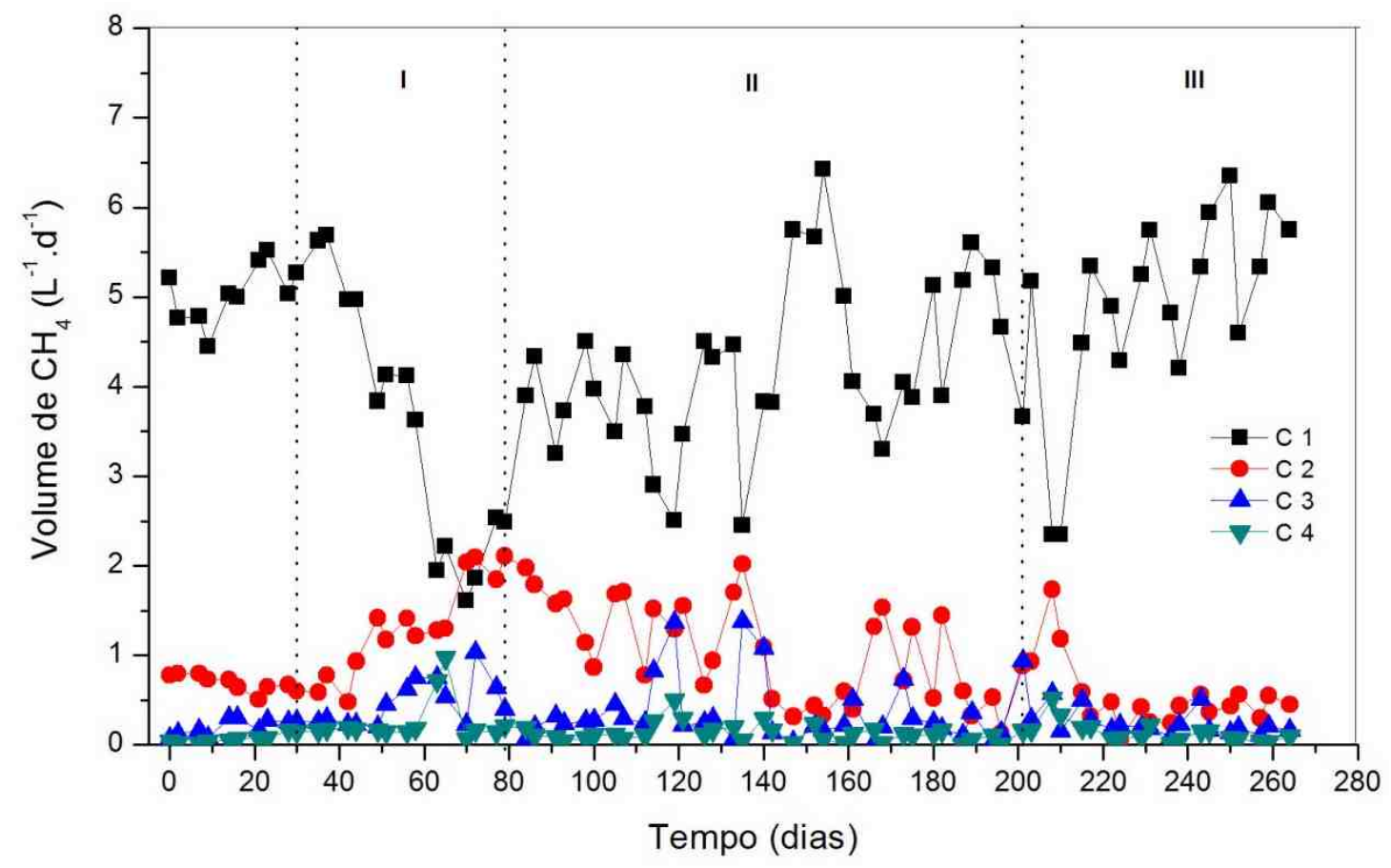

Figura 5.20 - Variação temporal da produção volumétrica de metano para as câmaras

$$
\mathrm{C} 1, \mathrm{C} 2, \mathrm{C} 3 \text { e } \mathrm{C} 4 .
$$

Em todo o período de monitoramento do reator RAS, mesmo após os problemas operacionais verificados, a produção teórica de metano no sistema mostrou ser elevada.

Analisando a Figura 5.20 constata-se que, a maior produção de metano teórica foi de 6,440 L.d obtida em C1 na Fase II (COV de 7,91 kg DQO $\mathrm{m}^{-3} \cdot \mathrm{d}^{-1}$ ), verificando-se decréscimo para as câmaras subsequentes (C2, C3 e C4). 
Em termos de volume teórico de metano produzido ao longo das Fases I, II e III, observa-se maior produção para a câmara $\mathrm{C} 1$. Os picos da produção de metano em $\mathrm{C} 1$ foram verificados para os maiores valores de carga orgânica aplicada, enquanto os períodos de queda da produção foram verificados para os períodos compreendidos por instabilidades operacionais do reator RAS.

Em termos de volume teórico de metano médio obtidos ao longo da Fase I, estes foram de 3,54 \pm 1,38 L.d; 1,33 \pm 0,52 L.d; 0,47 \pm 0,25 L.d e 0,26 \pm 0,27 L.d para C1, C2, C3 e C4, respectivamente, observando grande variação para as câmaras C2, C3 e C4.

Para a Fase II, os valores conseguidos para C1, C2, C3 e C4 foram de 4,20 $\pm 0,90$ L.d; 1,05 \pm 0,55 L.d; 0,36 \pm 0,35 L.d e 0,13 \pm 0,10 L.d, respectivamente, valores estes similares ao obtidos na Fase I para as câmaras C2, C3 e C4. Na Fase III, os valores médios de metano foram de 4,90 \pm 1,08 L.d (C1); 0,55 \pm 0,38 L.d (C2); 0,24 \pm 0,14 L.d (C3) e 0,14 $\pm 0,12$ L.d (C4).

A maior produção de metano observada na primeira câmara $(\mathrm{C} 1)$ possivelmente pode estar relacionado ao fato que esta apresentou os maiores valores de $\mathrm{COV}_{\text {individual }}$ $\mathrm{COAL}_{\text {individual }}$ (Figura 5.1), garantindo maior concentração de substrato orgânico passível de ser utilizado pela biomassa microbiana presente nesta câmara, corroborando para maior conversão em biogás (metano).

Em contrapartida, as menores produções observadas para C2, C3 e C4, pode ser creditada as baixas concentrações de matéria orgânica (DQO) afluente à estas câmaras, bem como seus menores valores de COV aplicadas (Figura 5.1).

Na Figura 5.21 é apresentada a composição do biogás obtido em termos de metano e $\mathrm{CO}_{2}$ para as Fases I, II e III da operação do reator RAS. 

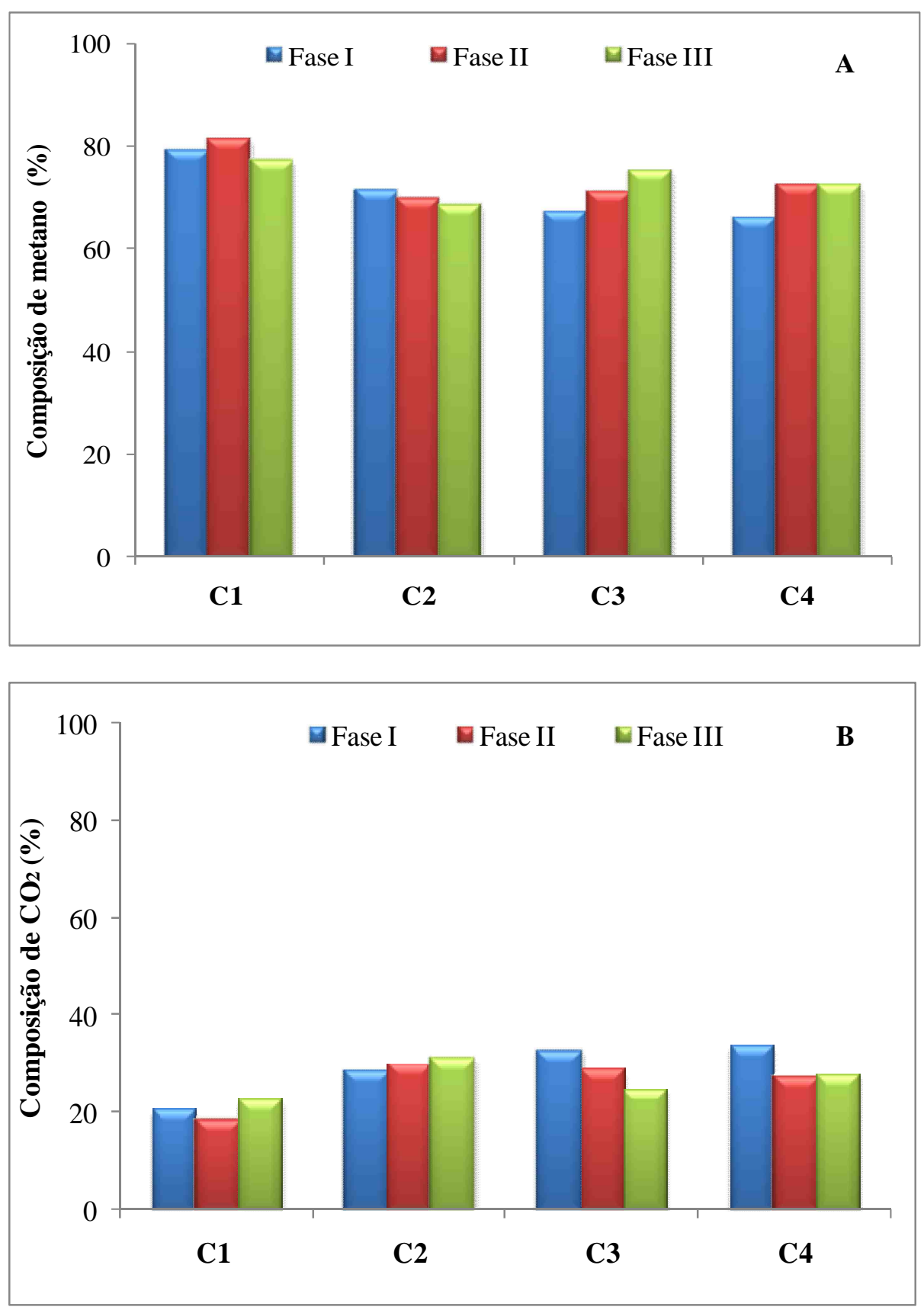

Figura 5.21 - Composição de metano (a) e $\mathrm{CO}_{2}$ (b) presente no biogás obtido para as câmaras C1, C2, C3 e C4.

Em relação à composição do biogás produzido, determinada por cromatografia gasosa (Figura 5.21), observou-se maior percentual de metano em relação ao $\mathrm{CO}_{2} \mathrm{em}$ todas as câmaras, demonstrando o equilíbrio do processo de digestão anaeróbia da vinhaça sem a inibição da etapa de metanogênese. 
Em todas as fases da operação (I, II e III), verificou-se que o metano é o gás predominante no biogás, com valores expressivos acima de $80 \%$ (C1), que confirmam o estabelecimento do sistema metanogênico pleno.

Os valores percentuais médios de metano obtidos para C1, C2, C3 e C4 durante a Fase I foram de 79,3\%,71,4\%, 67,2\% e 66,0\%, enquanto para $\mathrm{CO}_{2}$ estes foram de $20,7 \%, 28,6 \%, 32,8 \%$ e $34,0 \%$, respectivamente.

Para as Fases II e III, observou-se o ligeiro aumento da composição de metano presente no biogás produzido, com valores médios de 81,3 e 77,4\% (C1), 70 e 68,6\% (C2), 71,2 e 75,2\% (C3) e, 72,5 e 72,3\% (C4), respectivamente. Foram observadas reduções nas concentrações de metano nos momentos de ajuste nos parâmetros operacionais (para cada incremento da COV).

Parkin e Owen (1986); Speece (1996); Spinosa e Vesilind (2003) apontaram a redução da produção de metano como uma evidência para o desequilíbrio do processo de digestão anaeróbia.

Soares (2015) operando um reator anaeróbio de leito estruturado tratando vinhaça de cana-de-açúcar, a autora observou que o aumento gradativo da COV aplicada possibilitou o aumento progressivo da remoção da carga orgânica volumétrica, da produção de biogás e consequentemente da porcentagem de metano no biogás, assim como constatado neste estudo.

Os resultados obtidos demonstraram que o reator RAS possibilitou a produção de biogás com melhor qualidade energética em termos de composição de metano, como resultado da carga orgânica individual aplicada em cada um dos compartimentos. A predominância e abundância relativa dos grupos de microrganismos do gênero Archaea identificada no sequenciamento filogenético (item 5.1.4.3) reforçam esta hipótese. 


\subsubsection{Atividade metanogênica da biomassa}

O ensaio de atividade metanogênica (AME) foi realizado ao final da operação do reator RAS com amostras da biomassa de cada câmara. Na Figura 5.22 é apresentada a produção acumulada de metano obtida do ensaio de AME para o lodo das câmaras do reator.

A atividade metanogênica específica do lodo proveniente das câmaras do RAS ao

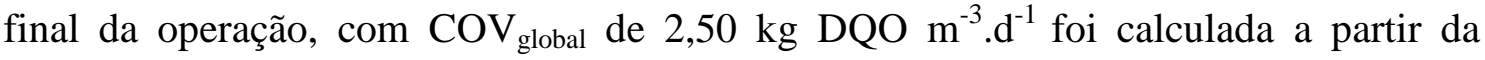
velocidade de produção acumulada de metano produzido no ensaio de acordo com James et al. (1990).

O início da produção de metano foi verificado logo após as primeiras 5 horas de incubação, sendo a máxima produção e estabilização desta, observadas após 60 e 80 horas, respectivamente (Figura 5.22).

O lodo proveniente das quatro câmaras do RAS coletados ao final da operação apresentou diferentes valores de AME. Os valores de metano obtidos do ensaio de atividade metanogênica para as câmaras $\mathrm{C} 1, \mathrm{C} 2$, C3 e C4 foram de 22,08; 3,42; 2,20 e $1,85 \mathrm{~mL} \mathrm{CH}_{4} / \mathrm{g} \mathrm{STV} . \mathrm{h}^{-1}$, respectivamente.

Este acontecido se deve muito provavelmente, à maior atividade microbiana da biomassa em $\mathrm{C} 1$, provocando alteração no comportamento das bactérias em $\mathrm{C} 2$, C3 e C4 por limitação de substrato (Levenspiel, 1998), bem como pelos valores de abundância relativa de organismos metanogênicos identificados nas análises de biologia molecular (item 5.1.4.2) e sequenciamento (item 5.1.4.3) apresentados posteriormente. 

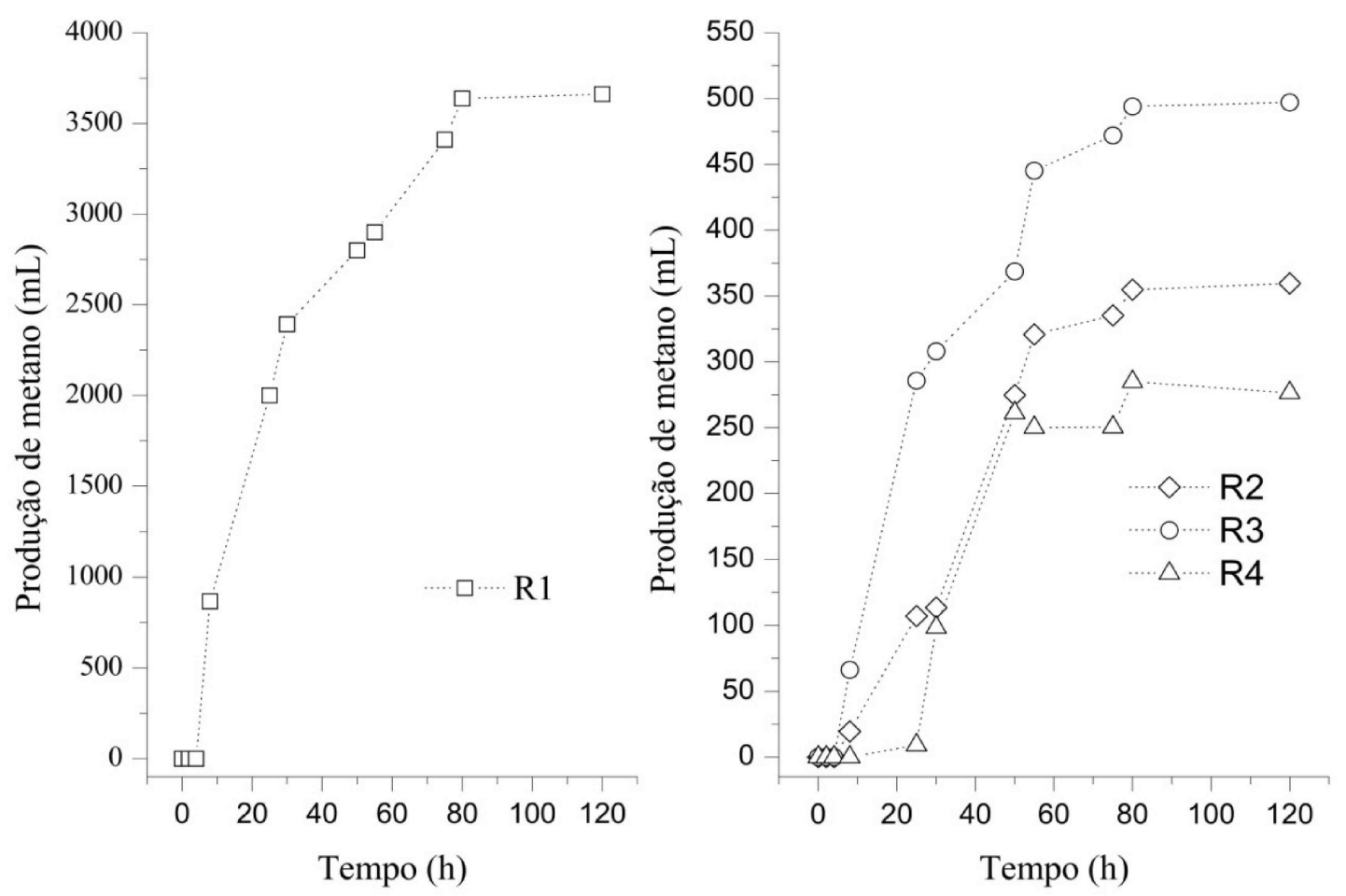

Figura 5.22 - Produção acumulada de metano durante o ensaio de AME para o lodo das câmaras C1, C2, C3 e C4.

De acordo com Serra-Alvarez e Lettinga (1991) a concentração do substrato pode afetar a taxa e o rendimento da produção de metano, provavelmente devido à inibição da atividade metanogênica por compostos fenólicos ou outros intermediários.

No entanto, as características qualitativas da composição da vinhaça utilizada na alimentação do reator RAS neste estudo (Tabela 4.1), não afetaram a produção de metano em termos de compostos fenólicos e/ou metais pesados presentes, por exemplo.

Boopathy (1998) utilizando um reator ABR em sistema contínuo no tratamento de efluente de suinocultura, COV de $4 \mathrm{~kg}$ DQO $\mathrm{m}^{-3} \cdot \mathrm{d}^{-1}$, concentração de DQO afluente de 13,67 g/L ${ }^{-1}$, TDH de 14 dias, obteve produção de metano de $0,59 \mathrm{~L}^{-1} \mathrm{CH}_{4} / \mathrm{g} \mathrm{STV}$, resultado semelhante ao obtido em $\mathrm{C} 1\left(0,53 \mathrm{~L}^{-1} \mathrm{~g} \mathrm{STV}\right)$.

Monteggia (1991) encontrou valores de AME similares ao obtido neste estudo, principalmente em C1, para lodo de cervejaria entre 21 a $23 \mathrm{~mL} \mathrm{CH} / \mathrm{g} \mathrm{STV} . \mathrm{h}^{-1}$ e 
valores próximo de 6,5 a 7,5 $\mathrm{mL} \mathrm{CH}_{4} / \mathrm{g} \mathrm{SSV} . \mathrm{h}^{-1}$ para lodo tratando efluentes de papel e celulose e lodo de efluente de soro de leite, respectivamente. No entanto, o autor não separou a parcela do $\mathrm{CO}_{2}$, que se constitui em parcela significativa da composição do biogás produzido.

\subsubsection{Caracterização da biomassa microbiana}

\subsubsection{Caracterização por microscopia}

Com o objetivo de caracterizar a biomassa microbiana granular do lodo de inóculo e das câmaras do reator RAS, foram realizados exames microscópicos em contraste de fase e MEV ao final da Etapa 1.

As principais morfologias observadas tanto para o inóculo quanto para as câmaras C1, C2, C3 e C4 são apresentadas na Figura 5.23. Foram observadas distintas morfologias microbianas nas amostras do lodo de inóculo e para as câmaras do RAS no final da Etapa 1.

Em relação à amostra do lodo de inóculo (Figura 5.23 A), aparentemente predominaram bacilos com dimensões variadas e Methanosaeta sp. Para as amostras das quatro câmaras do reator, houve ligeira distinção em relação à densidade morfológica da biomassa.

Para C1 e C2 (Figuras 5.23 B e 5.23 C, respectivamente), foram observados predomínio de Methanosaeta sp., (quando comparado ao inóculo), leveduras, bacilos curvos semelhantes a BRS, e poucas células semelhantes a Methanosarcina sp. Para C3

e C4 (Figuras 5.23 D e 5.23 E, respectivamente), observou-se aparente diminuição da 
densidade de arqueias metanogênicas. Entretanto, com relação às bactérias bacilares, não foi observada diferença significativa entre as câmaras do reator.

Essa variação da densidade e diversidade morfológica verificada para os microrganismos presentes nas diferentes câmaras do RAS possivelmente foram decorrentes das condições operacionais individualizadas, encontradas em cada câmara do reator em termos de fornecimento de substrato orgânico $\left(\mathrm{COV}_{\text {individual }}\right.$ e $\mathrm{COAL}_{\text {individual }}$ aplicadas).

Também foram realizados exames de microscopia eletrônica de varredura (MEV) para a verificação das estruturas granulares e distribuição das morfologias celular na camada interior e o núcleo dos grânulos do inóculo e das câmaras do reator tomadas a partir da amostragem dos pontos P1, P2 e P3 (Figura 5.24).

Observou-se, a partir das imagens de MEV obtidas semelhanças na distribuição e diversidade de morfologias microbianas presentes nos grânulos do inóculo e das câmaras do reator (Figura 5.24).

Para o lodo de inóculo (Figura 5.24 A, B e C) foi observada a predominância de grande quantidade de bacilos com dimensões variadas, com predomínio de Methanosaeta sp. Para as amostras das quatro câmaras do reator, foram observados comportamentos diferentes em relação à densidade morfológica das células microbianas. 

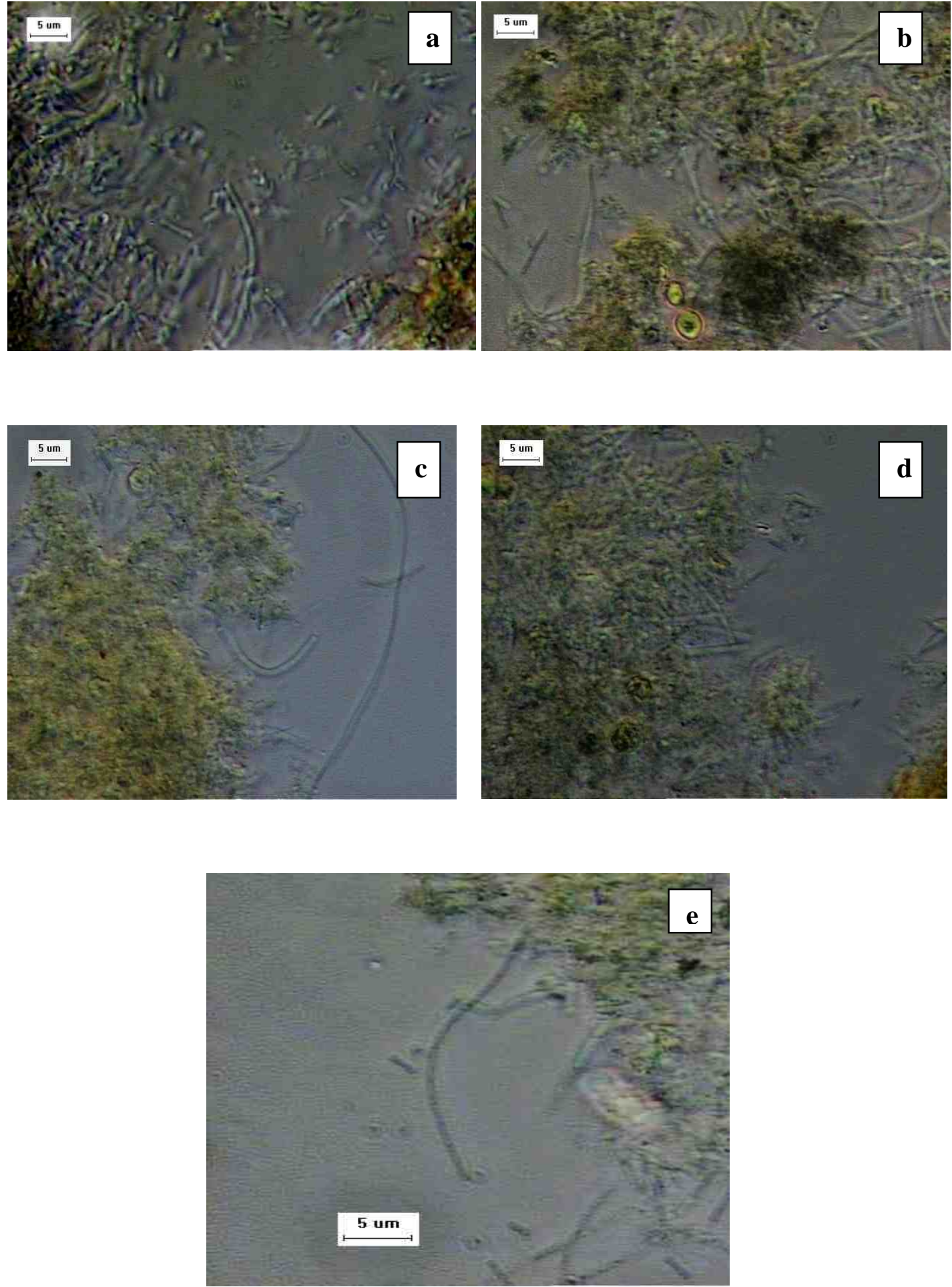

Figura 5.23 - Morfologias microbianas observadas para o lodo de inóculo e as câmaras do RAS sob microscopia óptica. Inóculo (a), C1 (b), C2 (c), C3 (d) e C4 (e).

À medida que se caminha da $\mathrm{C} 1$ para $\mathrm{C} 4$, observa-se um aumento de material polimérico no interior do grânulo. As morfologias microbianas semelhantes a 
Methanosaeta sp., cocos e bacilos, foram evidenciadas nos pontos P2 e P3 para as amostras da C1, C2, C3 e C4, enquanto para o inóculo, foi verificada a presença de Methanosaeta sp. para todos os pontos amostrais.

Entretanto, verifica-se que as morfologias semelhantes a Methanosaeta sp. perderão a integridade estrutural das células a medida que se caminha da $\mathrm{C} 1$ para $\mathrm{C} 4$, possivelmente em função da redução gradativa da disponibilidade de substrato, tendo em vista que as cargas orgânicas aplicadas ao final da operação do reator quando foram coletadas as amostras de biomassa eram de 10,$02 ; 1,71 ; 1,01$ e $0,75 \mathrm{~kg}$ DQO m m $^{-3} \mathrm{~d}^{-1}$ para $\mathrm{C} 1, \mathrm{C} 2, \mathrm{C} 3$ e $\mathrm{C} 4$, respectivamente. 


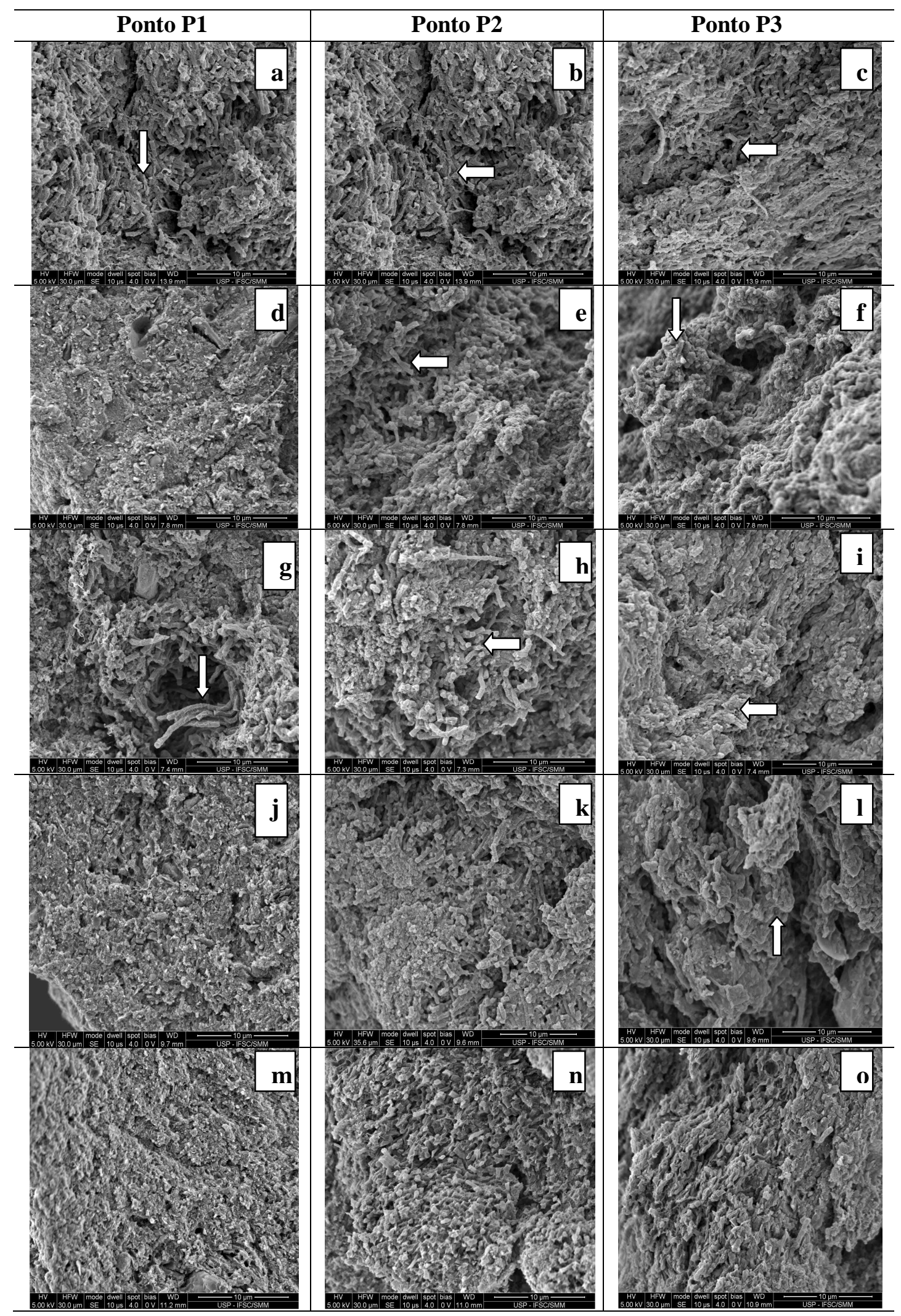

Figure 5.24 - Imagens da MEV obtidas para as amostra do inóculo e das câmaras do reator RAS. Inóculo (A, B e C); C1 (D, E e F); C2 (G, H e I); C3 (J, K e L) e C4 (M, N e O). 
As últimas câmaras do reator RAS possivelmente são alimentadas com material de difícil degradabilidade e/ou recalcitrante, corroborando para perda da integridade das morfologias observadas (Figura 5.24 M, N e O), tendo em vista que o valor médio de DQO bruta afluente durante o intervalo de operação do reator para a C4 $\left(1,16\right.$ g.L $\left.{ }^{-1}\right)$ foi inferior em comparação com a C1 (17,42 g.L $\left.\mathrm{L}^{-1}\right)$. Possivelmente a complexidade dos compostos contidos na vinhaça (principalmente proteínas e ácidos), levou a uma distribuição espacial não uniforme das morfologias contidas nos grânulos.

Independente do ponto de amostragem (P1, P2 e P3), não foi constatado a presença de hollow cores nas amostras. A presença de núcleos ocos podem ter resultado de uma diminuição na difusão de substrato devido ao maior tamanho de grânulo ou a baixa carga orgânica aplicada no reator (Del Nery et al., 2008).

Na Tabela 5.1 são apresentadas de forma resumida, as principais morfologias microbianas predominantes observadas na MEV para o lodo de inóculo e para a biomassa das câmaras do RAS.

Tabela 5.1. Resumo das principais morfologias microbianas observadas pela MEV.

\begin{tabular}{|c|c|c|c|c|c|}
\hline Pontos & Inóculo & $\overline{C 1}$ & $\overline{\mathrm{C2}}$ & $\overline{\mathrm{C3}}$ & $\mathrm{C4}$ \\
\hline P1 & $\begin{array}{l}\text { Cocos e } \\
\text { bacilos, } \\
\text { Methanosaeta }\end{array}$ & $\begin{array}{l}\text { Afloramento } \\
\text { de } \\
\text { Methanosaeta }\end{array}$ & $\begin{array}{l}\text { Cocos e } \\
\text { bacilos, } \\
\text { Methanosaeta }\end{array}$ & $\begin{array}{l}\text { Material } \\
\text { particulado, } \\
\text { precipitados, } \\
\text { Cocos, bacilos }\end{array}$ & $\begin{array}{l}\text { Methanosaetasp.com } \\
\text { perda de integridade } \\
\text { morfológica }\end{array}$ \\
\hline P2 & $\begin{array}{l}\text { Methanosaeta, } \\
\text { cocos e } \\
\text { bacilos }\end{array}$ & $\begin{array}{l}\text { Methanosaeta, } \\
\text { material } \\
\text { particulado, } \\
\text { precipitados }\end{array}$ & $\begin{array}{l}\text { Methanosaeta, } \\
\text { precipitado }\end{array}$ & $\begin{array}{l}\text { Methanosaeta, } \\
\text { material } \\
\text { particulado }\end{array}$ & $\begin{array}{l}\text { Methanosaeta, } \\
\text { material particulado }\end{array}$ \\
\hline P3 & $\begin{array}{l}\text { Alta } \\
\text { concentração } \\
\text { de } \\
\text { Methanosaeta }\end{array}$ & $\begin{array}{l}\text { Alta } \\
\text { concentração } \\
\text { de } \\
\text { Methanosaeta }\end{array}$ & $\begin{array}{l}\text { Methanosaeta, } \\
\text { cocos e } \\
\text { bacilos }\end{array}$ & $\begin{array}{l}\text { Methanosaeta, } \\
\text { cocos e } \\
\text { bacilos }\end{array}$ & $\begin{array}{l}\text { Methanosaeta sem } \\
\text { integridade } \\
\text { morfológica }\end{array}$ \\
\hline P3 & $\begin{array}{l}\text { Ausência de } \\
\text { hallow core }\end{array}$ & $\begin{array}{l}\text { Ausência de } \\
\text { hallow core }\end{array}$ & $\begin{array}{l}\text { Ausência de } \\
\text { hallow core }\end{array}$ & $\begin{array}{l}\text { Ausência de } \\
\text { hallow core }\end{array}$ & $\begin{array}{l}\text { Ausência de hallow } \\
\text { core }\end{array}$ \\
\hline
\end{tabular}




\subsubsection{Caracterização por técnicas de biologia molecular}

A caracterização qualitativa da comunidade microbiana da biomassa presente nas câmaras do RAS bem como para o lodo de inóculo, foram determinadas para os domínios Bacteria e Archaea, empregando técnicas de biologia molecular, tais como reação em cadeia da polimerase (PCR), seguida da eletroforese em gel de gradiente desnaturante (DGGE).

Na Figura 5.25 é apresentado o dendograma obtido para o domínio Archaea por meio do perfil das bandas de DGGE, das amostras das câmaras do RAS e do inóculo.

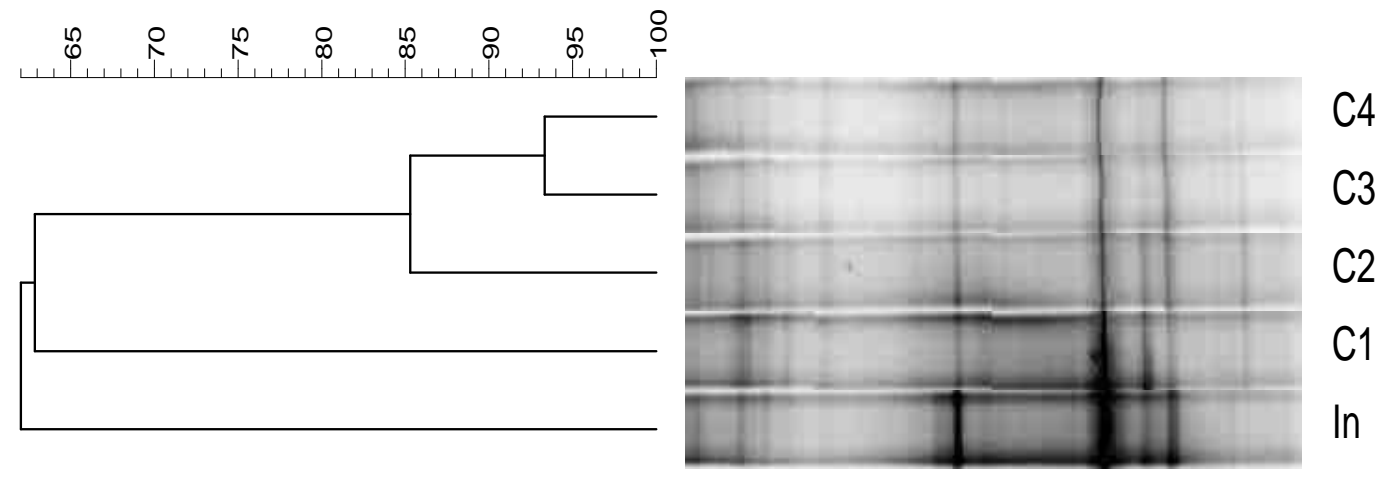

Figura 5.25 - Dendograma (UPGMA) obtido a partir do perfil das bandas de DGGE para o Domínio Archaea.

Na Figura 5.26 é apresentada a correlação entre os índices de diversidade Shannon e a dominância obtida para o domínio Archaea das amostras analisadas. 


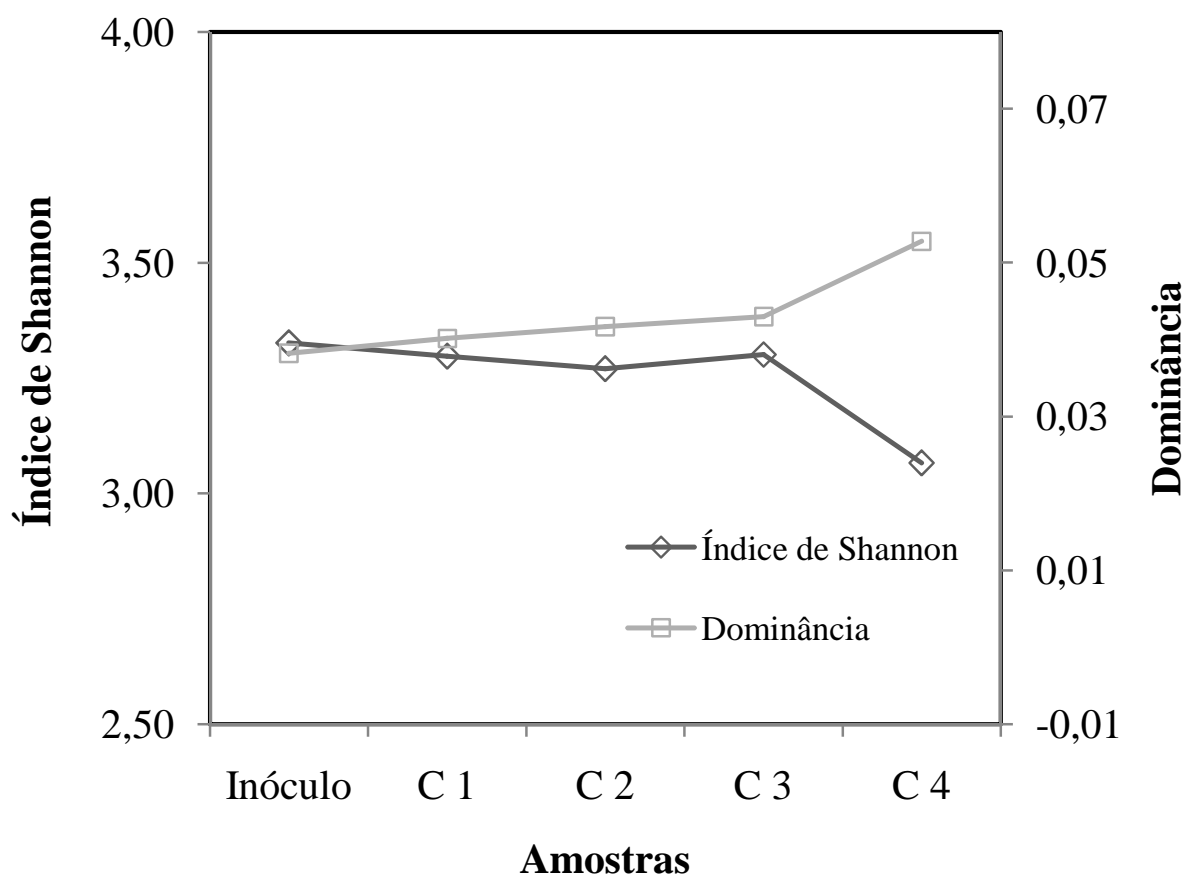

Figura 5.26 - Correlação do Índice de diversidade Shannon e a dominância para o grupo Archaea.

Na Figura 5.27 é apresentado o dendograma obtido para o domínio Bacteria por meio do perfil das bandas de DGGE, das amostras das câmaras do RAS e do inóculo.
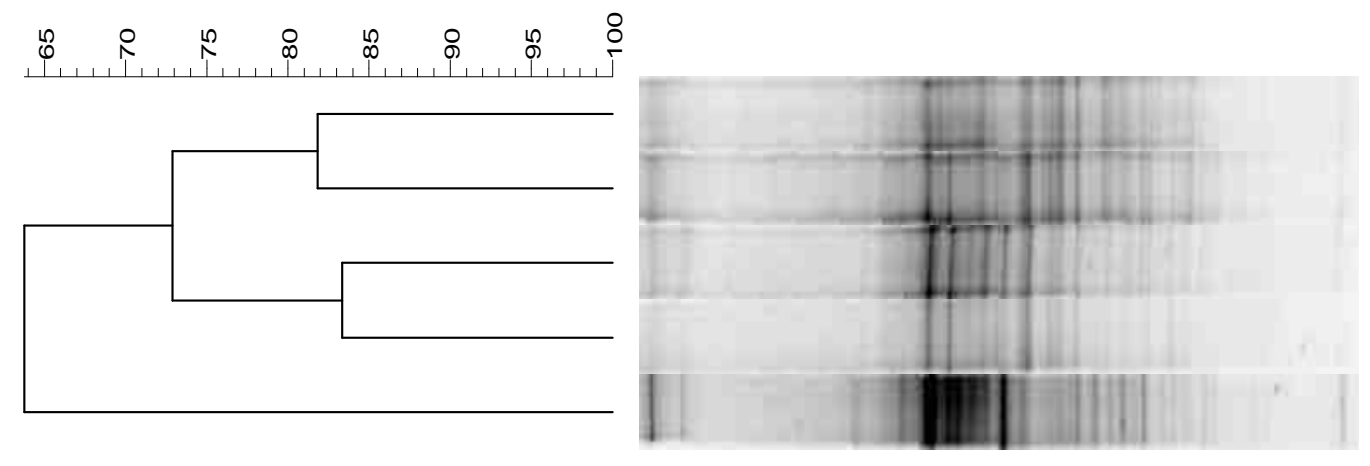

Figura 5.27 - Dendograma (UPMGA) obtido a partir do perfil das bandas de DGGE para o Domínio Bacteria. 
A Figura 5.28 apresenta a correlação entre os índices de diversidade Shannon e a dominância obtida para o domínio Bacteria das amostras analisadas.

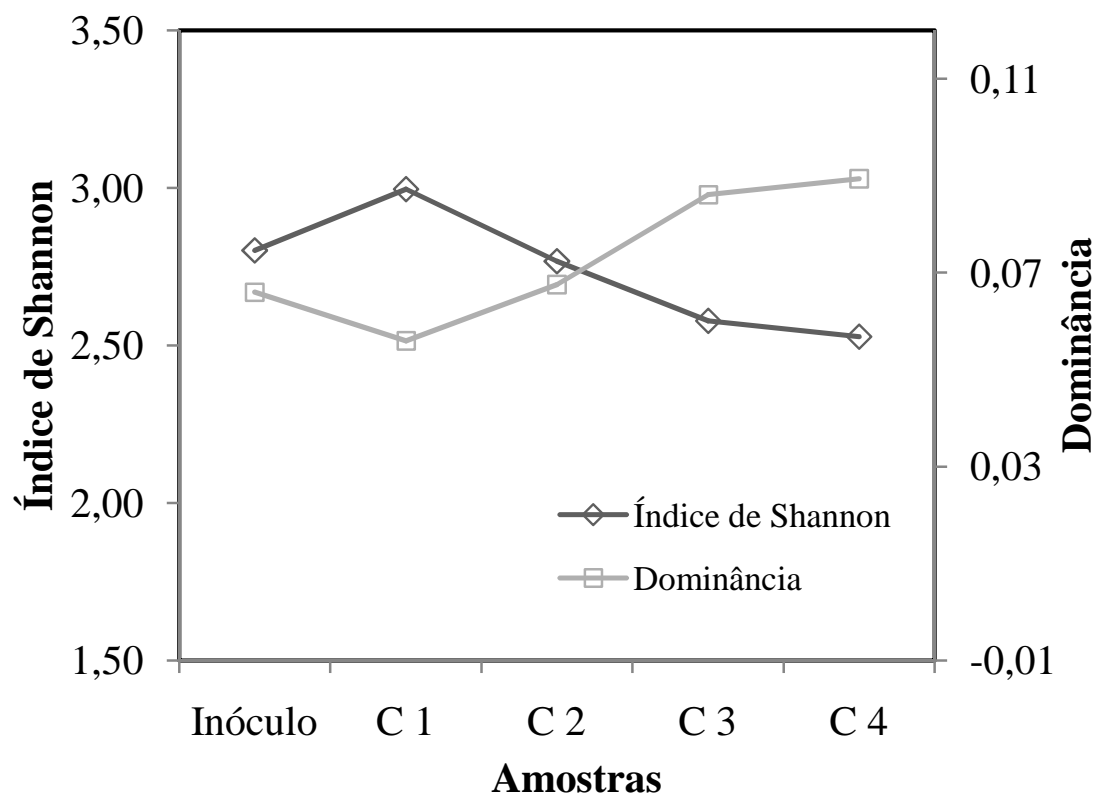

Figura 5.28 - Correlação do Índice de diversidade de Shannon e a dominância para o domínio Bacteria.

O índice de diversidade Shannon observado para o lodo de inóculo foi maior em relação às amostras do reator RAS para o domínio Archaea, no entanto, para o domínio Bacteria foi menor com exceção da $\mathrm{C} 1$, possivelmente pelo fato desta câmara receber maior teor de matéria orgânica em relação às demais.

À medida que se avança de C1 para C4 observa-se uma diminuição dos índices de diversidade para ambos os Domínios Archaea e Bacteria (C1 C2 $\quad$ C3 C4), conforme observado nas Figuras 5.26 e 5.28. Ou seja, ocorreu a seleção dessas populações microbianas, provavelmente, vinculada a concentração do substrato afluente em termos de DQO como já comentado. 
Com relação a dominância das populações microbianas verificou-se um aumento gradual para ambos os domínios Archaea e Bacteria (Figuras 5.26 e 5.28) ao longo das câmaras (C1 $\quad$ C2 $\quad$ C3 $\quad$ C4 $)$, indicando a especialização de algumas populações microbianas nas condições submetidas, ou seja, relacionada à concentração do substrato afluente às câmaras do RAS.

Quando o índice de diversidade Shannon reduz, observa-se o aumento da dominância, indicando provavelmente a adaptação de algumas populações, para ambos os domínios Bacteria e Archaea, principalmente da C3 para C4.

A comparação das comunidades microbianas foi determinada pelo cálculo dos coeficientes de similaridade Jacard para ambos os domínios Bacteria e Archaea a partir dos perfis de banda do DGGE (Figuras 5.25 e 5.27).

A comunidade microbiana do lodo de inóculo comparado com todas as câmaras do RAS apresentou coeficiente de similaridade de $63 \%$ e $64 \%$ para o domínio Archaea e Bacteria, respectivamente.

Os coeficientes de similaridade para o domínio Archaea (Figura 5.25) aumentaram ao longo das câmaras (C1 - 63\% - C2- 86\% - C3 - 93\% - C4). Este aumento na similaridade das populações de arqueias provavelmente esteja relacionado à semelhança entre os valores de $\mathrm{COAL}_{\text {individual }}$ aplicados principalmente na $\mathrm{C} 3$ e C4 (0,07

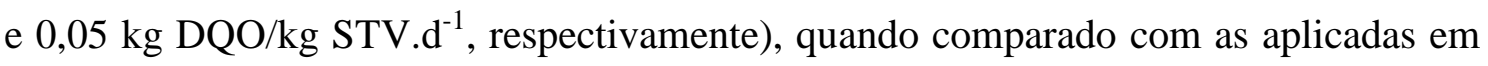
C1 e C2 (0,44 e 0,13 kg DQO/kg STV.d ${ }^{-1}$, respectivamente), corroborando com os exames microscópicos e MEV apresentados anteriormente.

Os coeficientes de similaridade para o domínio Bacteria (Figura 5.27) foi de $82 \%$ comparando-se $\mathrm{C} 1$ e C2, e de $83 \%$ entre $\mathrm{C} 3$ e C4, ou seja, a maioria das populações bacterianas manteve-se nessas câmaras apesar da diferença dos valores de COV 
aplicada, provavelmente, tais populações já estivessem adaptadas a condições operacionais do reator.

\subsubsection{Análise filogenética das amostras do reator RAS}

Neste tópico são apresentados e discutidos os resultados obtidos das análises do sequenciamento filogenético das amostras do lodo de inóculo e biomassa das câmaras, ao final da operação do reator anaeróbio serial na Etapa 1.

As amostras de DNA genômico da biomassa microbiana proveniente do inóculo e das câmaras do reator RAS foram sequenciadas por meio da plataforma Illumina para os domínios Bactéria e Archaea.

Na Figura 5.29 são apresentados os resultados referentes ao filo, classe, ordem, família e gênero para o domínio Archaea, obtidos do sequenciamento do inóculo e das câmaras do reator RAS.

Observa-se a partir da Figura 5.29 que houve a predominância do filo Euryarchaeota para o lodo de inóculo e as amostras das câmaras do reator RAS. A abundância relativa observada para o inóculo foi de 94,34 \%, sendo que, para C1, C2, C3 e C4 esse valor foi da ordem de 97,64\%, 95,96\%, 95,91\% e 94,75\%, respectivamente, constatando-se permanência desse grupo de microbiano ao longo da operação do reator (280 dias).

O filo Euryarchaeota agrupa grande diversidade de organismos aeróbios, anaeróbios, termófilos e halófilos, existindo dois grupos principais: as archaea metanogênicas que são anaeróbios e as archaea halófilas, que são aeróbios (Sowers, 1995). Os organismos desse grupo incluindo as espécies metanogênicas, são 
amplamente reportados em sistemas de tratamento anaeróbio de águas residuárias na mineralização da matéria orgânica (Vazoller, 1995).

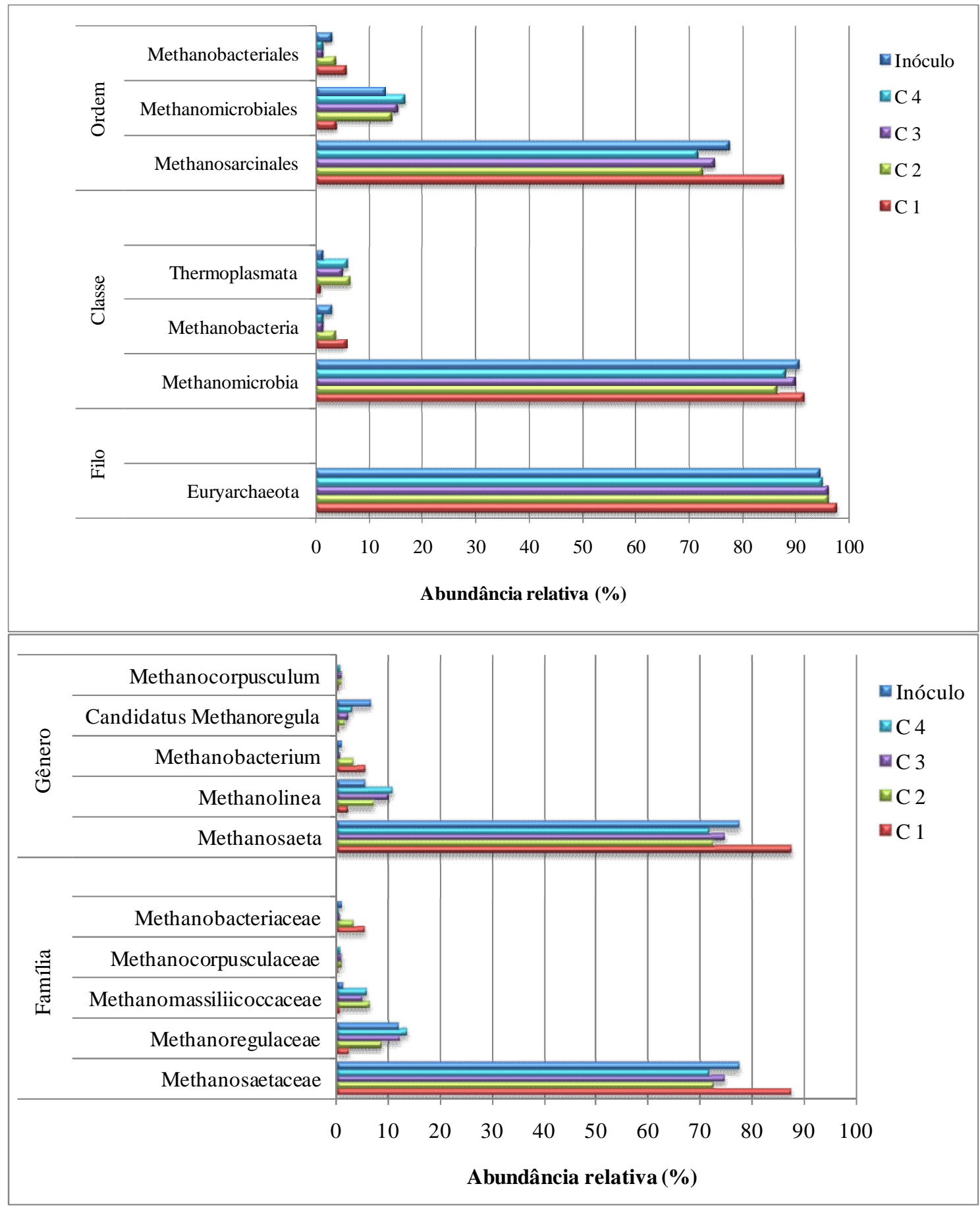

Figura 5.29 - Análise filogenética obtida do sequenciamento para o domínio Archaea. 
Ao mesmo passo, observou-se o predomínio do gênero Methanosaeta para o lodo de inóculo e para as câmaras do reator (Figura 5.29). Os valores percentuais de abundância relativa encontrados para esse grupo foram de 77,42 \%, 87,38 \%, 72,24 \%, 74,68 \% e 71,36 \% para o inóculo, C1, C2, C3 e C4, respectivamente. A Methanosaeta são arqueias metanogênicas acetoclásticas, especialistas na utilização de acetato como fonte de energia para a conversão em metano e dióxido de carbono (Boone et al., 2001).

Novamente, observou-se proximidade entre os valores de abundância relativa obtidos para ambas as amostras analisadas, sendo que, o maior valor obtido foi conseguido para $\mathrm{C} 1$, corroborando com os resultados da microscopia, MEV e DGGE.

Segundo Vazoller et al., (1995) entre as principais fontes de substratos para o desenvolvimento das arqueias metanogênicas tem-se o formiato, monóxido de carbono, metanol, 2-propanol, aminas metiladas, dimetilsulfeto, metilmercaptanas, acetato e dióxido de carbono.

A produção e disponibilidade de acetato, principalmente, verificada no tratamento de vinhaça neste trabalho, certamente proporcionaram condições favoráveis para o crescimento e manutenção dos grupos de arqueias metanogênicas, como observado pelo sequenciamento filogenético.

De modo geral, os maiores valores de abundância para o grupo de arqueias metanogênicas sequenciadas observadas para $\mathrm{C} 1$, contrastam com os dados operacionais do reator RAS já discutidos anteriormente, tendo em vista principalmente a maior produção de metano que essa câmara deteve ao longo da Etapa 1.

Aparentemente, as instabilidades operacionais do reator verificadas ao final das Etapas I e II, bem como o aumento de carregamento orgânico aplicado às câmaras, não levou a inibição dos grupos de arqueias metanogênicas ao final da operação do RAS, quando comparado ao lodo de inóculo. 
Este fato pode ser creditado à boa adaptabilidade da biomassa microbiana ao substrato orgânico fornecido, às condições ambientais e operacionais propiciadas ao desenvolvimento da etapa de metanogênese, adotadas no processamento anaeróbio da vinhaça de cana-de-açúcar.

No entanto, observa-se por meio da Figura 5.29 moderada seleção do grupo de Methanosaetaceae pertencentes ao gênero Methanosaeta da primeira câmara $(\mathrm{C} 1)$ para a última (C4), podendo ser creditada a diferença de COV aplicadas ao final da etapa III, da ordem de 10,02 e $0,75 \mathrm{~kg} \mathrm{DQO} / \mathrm{m}^{-3} \cdot \mathrm{d}^{-1}$ para $\mathrm{C} 1$ e $\mathrm{C} 4$, respectivamente.

Na Figura 5.30 são apresentados os resultados referentes ao filo, classe, ordem, família e gênero para o domínio Bacteria, obtidos do sequenciamento do lodo de inóculo e das câmaras do reator RAS.

Em relação ao domínio Bacteria, verificou-se que o filo Chloroflexi foi o mais abundante nas câmaras C1 (41,4\%), C2 (48,7\%), C3 (53\%) e C4 (49,9\%). Vale ressaltar que tal filo foi identificado na biomassa utilizada para inoculação do reator RAS apresentando abundância relativa no inóculo de 51,7\%.

O filo Chloroflexi agrupa microrganismos com metabolismos diversos, incluindo 6 classes, uma das quais (Chloroflexi) abrange a maior parte de microrganismos fototróficos. Contudo, nesta pesquisa, verificou-se que dentre as classes agrupadas por este filo, Anaerolineae foi a de maior abundância relativa representando 40,8\%, 48,3\%, 52,6\% e 49,4\%, respectivamente em C1, C2, C3 e C4. Representantes desta classe são estritamente anaeróbios sendo encontrados em reatores anaeróbios (Rosenberg et al., 2014). 


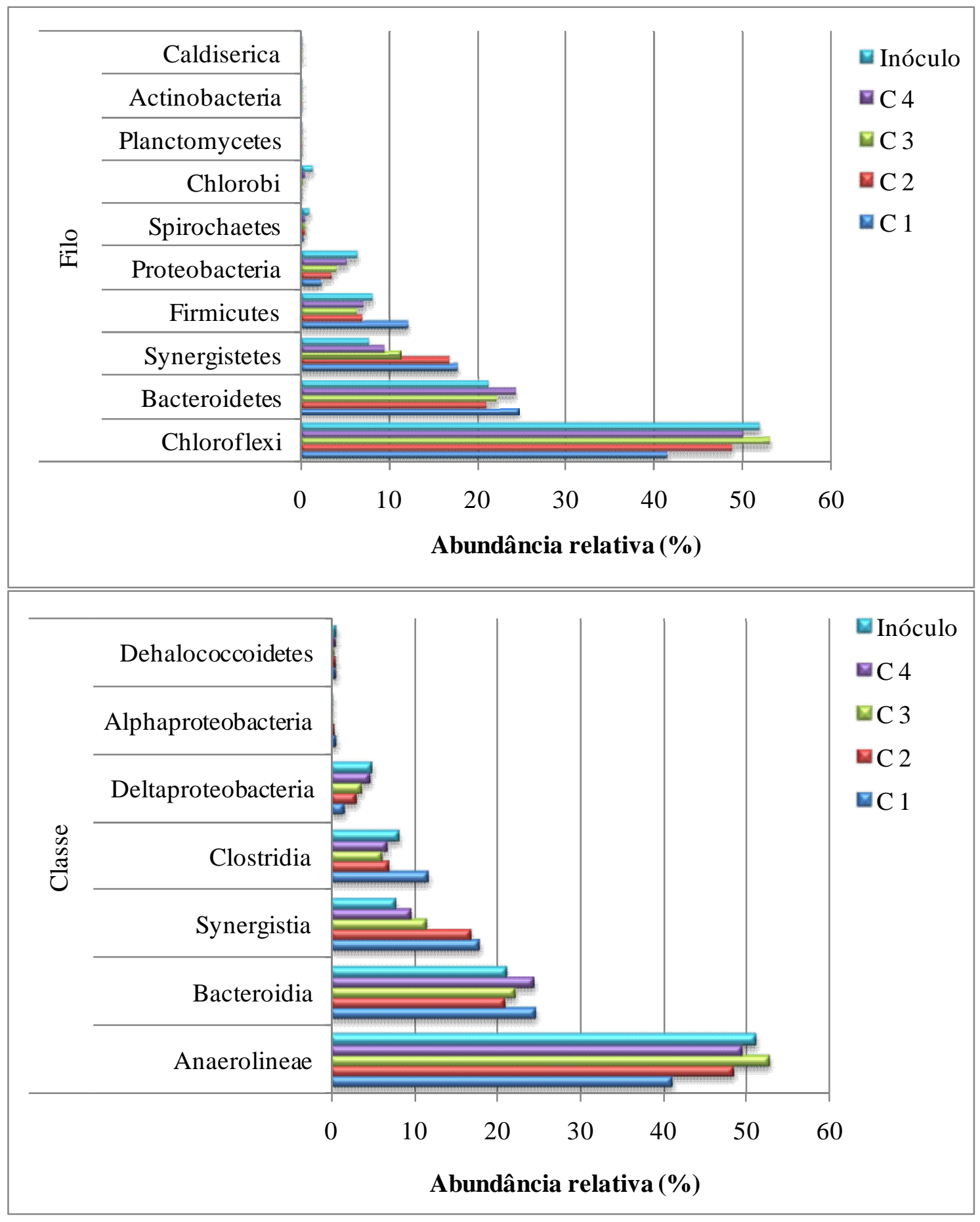

Figura 5.30 - Sequenciamento realizado para o domínio Bacteria. 


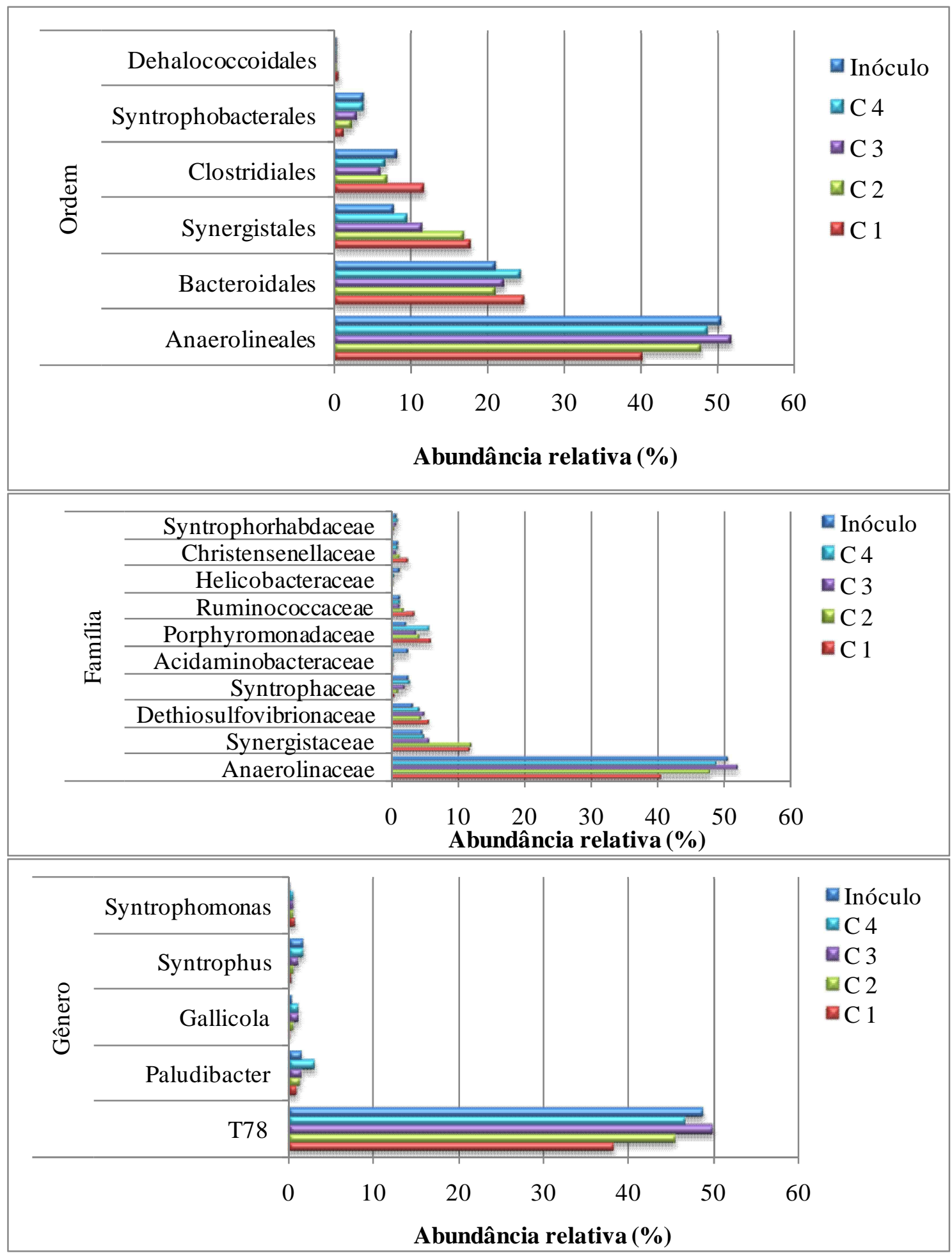

Figura 5.30 - Sequenciamento realizado para o domínio Bacteria (continuação).

O filo Bacteroidetes agrupou 24,6\%, 21\%, 22,1\% e 24,3\% das sequências obtidas nas câmaras C1, C2, C3 e C4, respectivamente. Ressalta-se que no inóculo tal filo foi identificado em $21,1 \%$ das sequencias, podendo-se inferir a permanência destes 
microrganismos possivelmente, devido às condições nutricionais estabelecidas ao longo da operação do reator (280 dias).

O filo supracitado agrupa microrganismos Gram negativos não formadores de endósporos, anaeróbios, e com metabolismo quimioheterotrófico, capazes de produzir ácidos orgânicos diversos como produtos finais da fermentação (Brenner et al., 2005).

Observou-se para o inóculo que o filo Synergistetes agrupou 7,8\% das sequencias em abundância relativa, por outro lado, verificou-se aumento da abundância relativa deste filo nas câmaras do RAS: 17,8\% (C1), 16,8\% (C2), 11,4\% (C3) e 9,5\% (C4). Incluem-se neste filo, microrganismos anaeróbios, Gram negativos com capacidade de degradação de aminoácidos, encontrados em diversos habitats, tais como digestores anaeróbios, ambientes marinhos, e ambientes com elevada concentração de enxofre (Brenner et al., 2005).

Representantes do filo Firmicutes agruparam, em abundância relativa, 8,1\% das sequencias no inóculo, enquanto nas câmaras do reator foram observadas abundâncias de: $12,2 \%(\mathrm{C} 1), 7,0 \%(\mathrm{C} 2), 6,4 \%(\mathrm{C} 3)$ e 7,0\% (C4). Microrganismos deste filo podem ser estritamente anaeróbios e anaeróbios facultativos, foram identificados em diversos reatores tratando resíduos na recuperação de energia, possuem metabolismo predominantemente quimiorganotrófico e a maior parte habita ambientes com $\mathrm{pH}$ neutro.

Em relação ao nível taxonômico de família, verificou-se que a família Anaerolinaceae agrupou 50,4\% das sequencias identificadas no inóculo, e membros desta família permaneceram no reator em elevada abundância relativa nas câmaras C1 $(40,2 \%)$, C2 (47,7\%), C3 (51,7\%) e C4 (48,6\%).

Observou-se que a abundância relativa das famílias Synergistaceae, Dethiosulfovibrionaceae e Porphyromonadaceae (Figura 6.2) aumentaram nas câmaras 
em relação ao inóculo, sugerindo que as condições de operação estabelecidas favoreceram o crescimento e manutenção dos organismos das referidas famílias.

Por outro lado, verificou-se redução na abundância relativa das famílias Acidaminobacteraceae e Helicobacteraceae nas câmaras do reator compartimentado, em relação ao inóculo de origem.

Em nível de gênero, observou-se classificação de 71,6\% (Inóculo), 72,8\% (C1), 74,7\% (C2), 73,9\% (C3) e 72,2\% (C4) das sequencias totais. Para a amostra do inóculo, observou-se que o gênero T78 (filo Chloroflexi) representou 48,6\% das sequencias em abundância relativa. Nas câmaras $\mathrm{C} 1, \mathrm{C} 2, \mathrm{C} 3$ e C4, este gênero foi identificado em $38,2 \%, 45,4 \%, 49,8 \%$ e 46,6\%, respectivamente. Tal gênero tem sido identificado em sistemas de digestão anaeróbia (Ariesyady et al., 2007) e está diretamente relacionado ao consumo de carboidratos.

Ressalta-se que a concentração afluente de carboidratos no reator anaeróbio compartimentado foi elevada $\left(1940 \pm 634 \mathrm{mg} . \mathrm{L}^{-1}\right)$ além disso, verificou-se elevada remoção de carboidratos nas câmaras, corroborando assim a alta abundância relativa observada para o gênero T78.

O gênero vadinCA02 (filo Synergistetes) foi identificado no inóculo em 4,46\% das amostras sequenciadas. Verificou-se que nas câmaras esse gênero agrupou em abundância relativa: 11,6\% (C1), 11,84\% (C2), 5,64\% (C3) e 4,8\% (C4). Bactérias semelhantes a este gênero tem sido identificada em sistemas de digestão anaeróbia de forragem de milho (Sträuber et al., 2015) e lodos primários (Li et al., 2015) e são descritas pela capacidade de degradação de aminoácidos.

Observou-se aumento na abundância relativa do gênero HA73 nas câmaras em relação ao inóculo de origem (2,9\%). Nas câmaras C1, C2, C3 e C4 este gênero agrupou $5,3 \%, 4,2 \%, 4,5 \%$ e $3,8 \%$ das sequencias identificadas. Este gênero está relacionado à 
família Dethiosulfovibrionaceae e através de relações sintróficas é capaz de degradar aminoácidos e consumo ácidos orgânicos (Hagen et al., 2016; Fan et al., 2015).

Observou-se o gênero Fusibacter (filo Firmicutes) em abundância relativa de 2,4\% no inóculo utilizado no reator, entretanto, ao longo do período de operação, verificou-se que houve redução na abundância relativa para este gênero para $0,07 \%$ (C1), 0,13\% (C2), 0,07\% (C3) e 0,31\% (C4). Tal gênero agrupa bactérias anaeróbias obrigatórias e metabolismo organotrófico, capazes de oxidar carboidratos em butirato, acetato, dióxido de carbono e hidrogênio. Adicionalmente, são microrganismos capazes de utilizar o enxofre ou o tiossulfato como receptores de elétrons durante a fermentação da glicose, produzindo ácido sulfídrico (Brenner et al., 2005).

Provavelmente, a redução na abundância relativa do gênero Fusibacter nas câmaras, pode ser creditada a elevada presença do gênero sacarolítico T78, outrossim, houve significativa remoção de carboidratos nas câmaras reduzindo o substrato passível de degradação pelo gênero Fusibacter limitando seu crescimento.

O gênero Syntrophus (Filo Proteobacteria) foi identificado nas câmaras C1, C2, C3 e C4 em abundância relativa de $0,29 \%, 0,63 \%, 1,14 \%$ e 1,81\%, respectivamente. São descritos como microrganismos anaeróbios estritos, fermentativos, capazes de degradar ácidos graxos em reações sintróficas com arqueias metanogênica hidrogenotróficas (Brenner et al., 2005; Rosenberg et al., 2014).

Paludibacter foi identificado em $0,94 \%$ (C1), 1,4\% (C2), 1,45\% (C3) e 3,03\% (C4) em abundância relativa. Tal gênero, pertencente ao filo Bacteroidetes, são organismos estritamente anaeróbio, capaz de fermentar diversos açucares tendo como produtos finais o acetato e propionato.

Syntrophobacter (filo Proteobacteria) são microrganismos estritamente anaeróbios, capazes de oxidar propionato em acetato na presença de arqueias 
hidrogenotróficas, sugerindo a importância de relações sintróficas para seu crescimento e estabelecimento. Bactérias semelhantes a este gênero foram identificadas em 0,55\% (C1), 0,88\% (C2), 0,37\% (C3) e 0,29\% (C4).

\subsection{ETAPA 2 - OPERAÇÃO DOS REATORES ASBR EM BATELADA}

Neste tópico estão descritos e discutidos os resultados obtidos dos ensaios em batelada na Etapa 2. Para tanto, são apresentados os resultados referentes ao monitoramento de desempenho dos reatores, a produção e composição do biogás, bem como a diversidade da comunidade microbiana presente em cada reator.

\subsubsection{Desempenho dos reatores em batelada sequencial}

$\mathrm{Na}$ segunda etapa do trabalho, os reatores anaeróbios operados em batelada sequencial (ASBR) foram mantidos sob agitação constante de $150 \mathrm{rpm}$, temperatura controlada de $25 \pm 3{ }^{\circ} \mathrm{C}$ e tempo de ciclo de 48 horas/frasco.

Após o tempo de ciclo estipulado, os frascos reatores foram deixados em repouso por um período de 60 min para sedimentação de material sólido em suspensão e posterior coleta do sobrenadante para a realização de análises.

Nas Figuras 5.31 e 5.32 são apresentados os valores de carga orgânica aplicada ao lodo (COAL) e carga orgânica obtida (CO) para os reatores, impostas nas Fases I, II e III nos ensaios em batelada, respectivamente. 


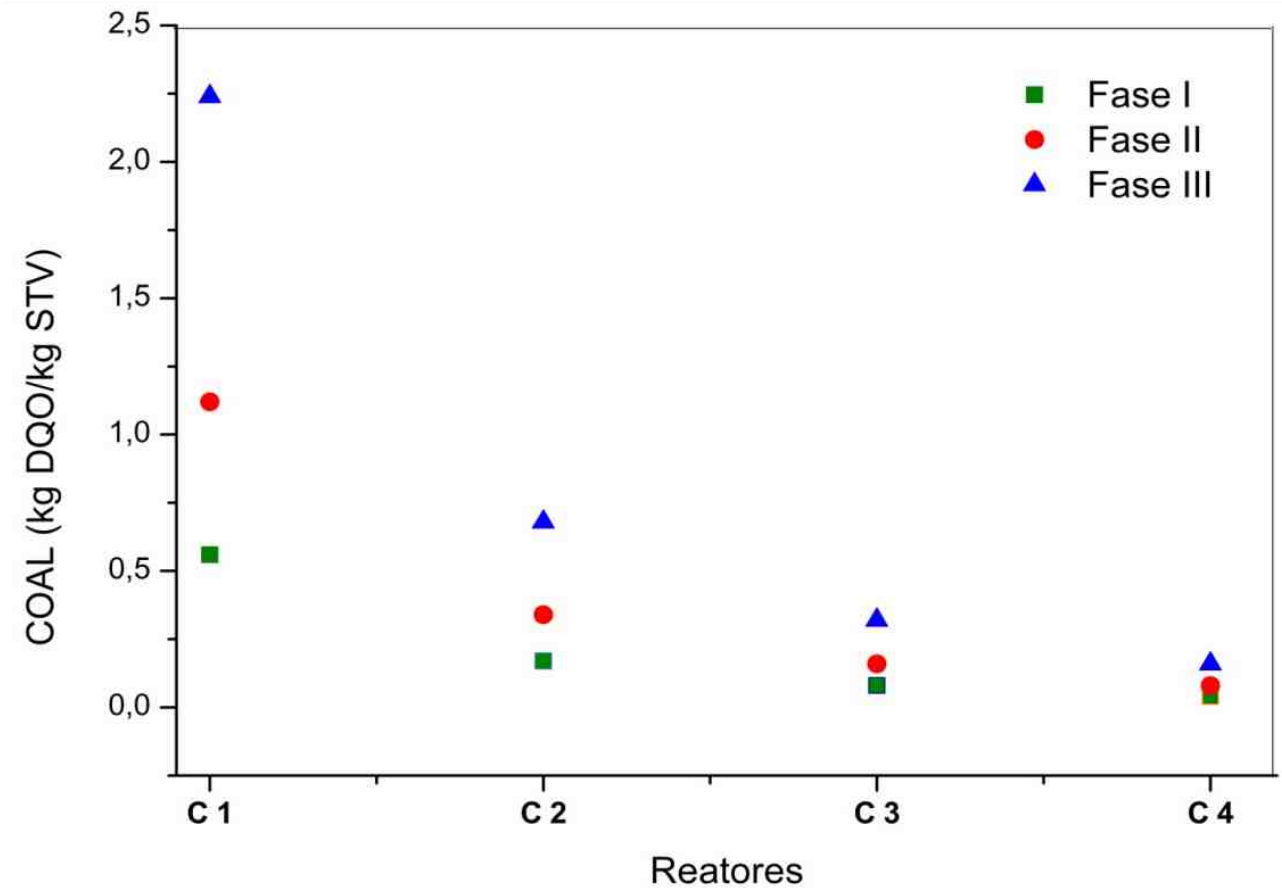

Figura 5.31 - Valores de COAL aplicadas ao lodo nas Fases I, II e III nos ensaios em regime de batelada.

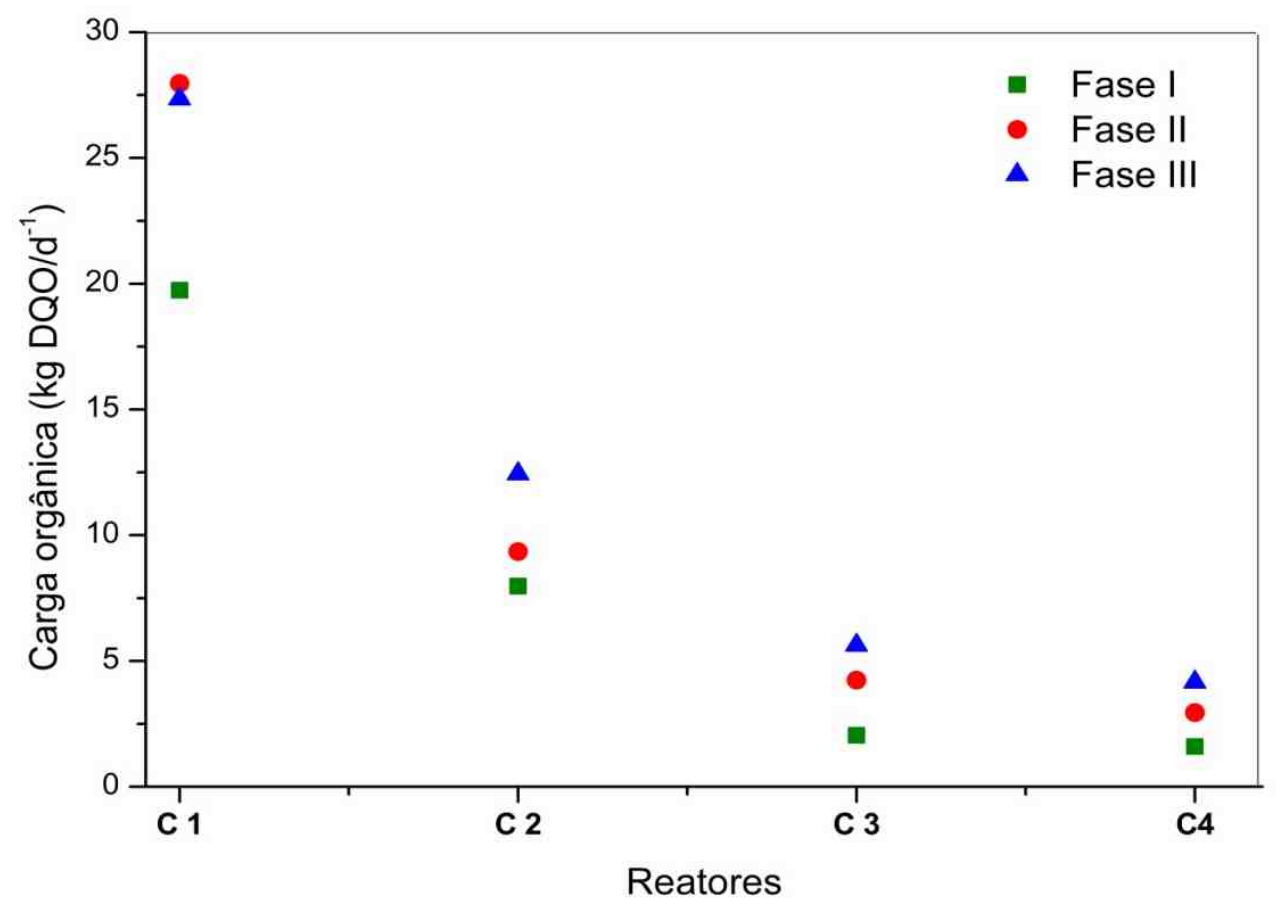

Figura 5.32 - Valores de carga orgânica obtidas para as Fases I, II e III nos ensaios em regime de batelada. 
As Fases I, II e III do ensaio em regime de batelada sequencial, consistiram na imposição de aumento da COAL de 0\%, 100\% e 400\%, respectivamente. Conforme apresentado pela Figura 5.32, o aumento da COAL consequentemente acarretou no aumento dos valores de carga orgânica aplicada aos reatores.

Na Fase I, os valores individuais de COAL foram de 0,56;0,17;0,08 e 0,04 kg DQO/kg STV.d $\mathrm{d}^{-1}$, valores estes similares aos obtidos no final da operação do reator RAC em regime estacionário na Etapa 1. Em relação aos valores de carga orgânica obtida (Figura 5.32) estes foram de 19,75; 4,01; 2,04 e 1,59 kg DQO/d ${ }^{-1}$ para os reatores $\mathrm{C} 1, \mathrm{C} 2, \mathrm{C} 3$ e $\mathrm{C} 4$, respectivamente.

Posteriormente na Fase II, com a duplicação imposta sobre a COAL obtida ao final da Fase I, os valores aplicados foram de 1,12; 0,34; 0,16 e 0,08 kg DQO/kg STV.d ${ }^{-}$ ${ }^{1}$ para C1, C2, C3 e C4, obtendo-se cargas orgânicas da ordem de 20,52; 6,23; 4,25 e $2,95 \mathrm{~kg} \mathrm{DQO} / \mathrm{d}^{-1}$, respectivamente.

Na última fase (Fase III), foram conseguidos valores mais elevados em termos de COAL aplicada e CO para ambos os reatores, principalmente para C2, C3 e C4 (Figuras 5.31 e 5.32), em virtude do aumento da concentração residual de matéria orgânica (DQO) efluente dos reatores $\mathrm{C} 1, \mathrm{C} 2$ e $\mathrm{C} 3$, influenciando diretamente nos valores de COAL e das cargas orgânicas obtidas.

Os valores de COAL aplicados nesta fase para os reatores $\mathrm{C} 1, \mathrm{C} 2, \mathrm{C} 3$ e $\mathrm{C} 4$ foram de 2,24; 0,68; 032 e 0,16 kg DQO kg STV.d ${ }^{-1}$, atingindo cargas orgânicas da ordem de 20,$05 ; 8,30 ; 5,63$ e 4,16 kg DQO/d ${ }^{-1}$, respectivamente.

Constatou-se que os aumentos nos valores de carga orgânica aplicada ao lodo (COAL) nos ensaios em batelada, não inibiram a degradação anaeróbia da vinhaça nas condições investigadas. 
Ribas (2006) avaliando o tratamento da vinhaça de cana-de-açúcar em reator anaeróbio operado em batelada sequencial, alcançou COV máxima de $36 \mathrm{~kg} \mathrm{DQO} / \mathrm{m}^{-}$ ${ }^{3} \cdot \mathrm{d}^{-1}$, respectivamente. Para o sistema proposto neste estudo, foi obtida carga orgânica máxima de $20 \mathrm{~kg} \mathrm{DQO} / \mathrm{m}^{-3} \cdot \mathrm{d}^{-1}$ para o reator $\mathrm{C} 1$, com a quadruplicação da COAL verificada na Fase III.

Nacheva et al. (2005) verificaram o aumento da remoção de matéria orgânica na forma de DQO com o aumento da carga orgânica aplicada, da ordem de 9, 12 e acima de $16 \mathrm{~g}$ DQO $\mathrm{L}^{-1} . \mathrm{d}^{1}$, utilizando um reator anaeróbio de leito expandido no tratamento de vinhaça de destilaria de álcool.

Visando avaliar o comportamento e a eficiência operacional dos reatores em sistema descontínuo, foram realizadas análises de DQO filtrada, carboidratos, $\mathrm{pH}$, ácidos orgânicos voláteis, produção de metano e composição do biogás.

Os valores de concentração de DQO filtrada e as eficiências de remoção para cada reator após os ensaios em batelada nas Fases I, II e III, são apresentados nas Figuras 5.33 e 5.34 , respectivamente. 

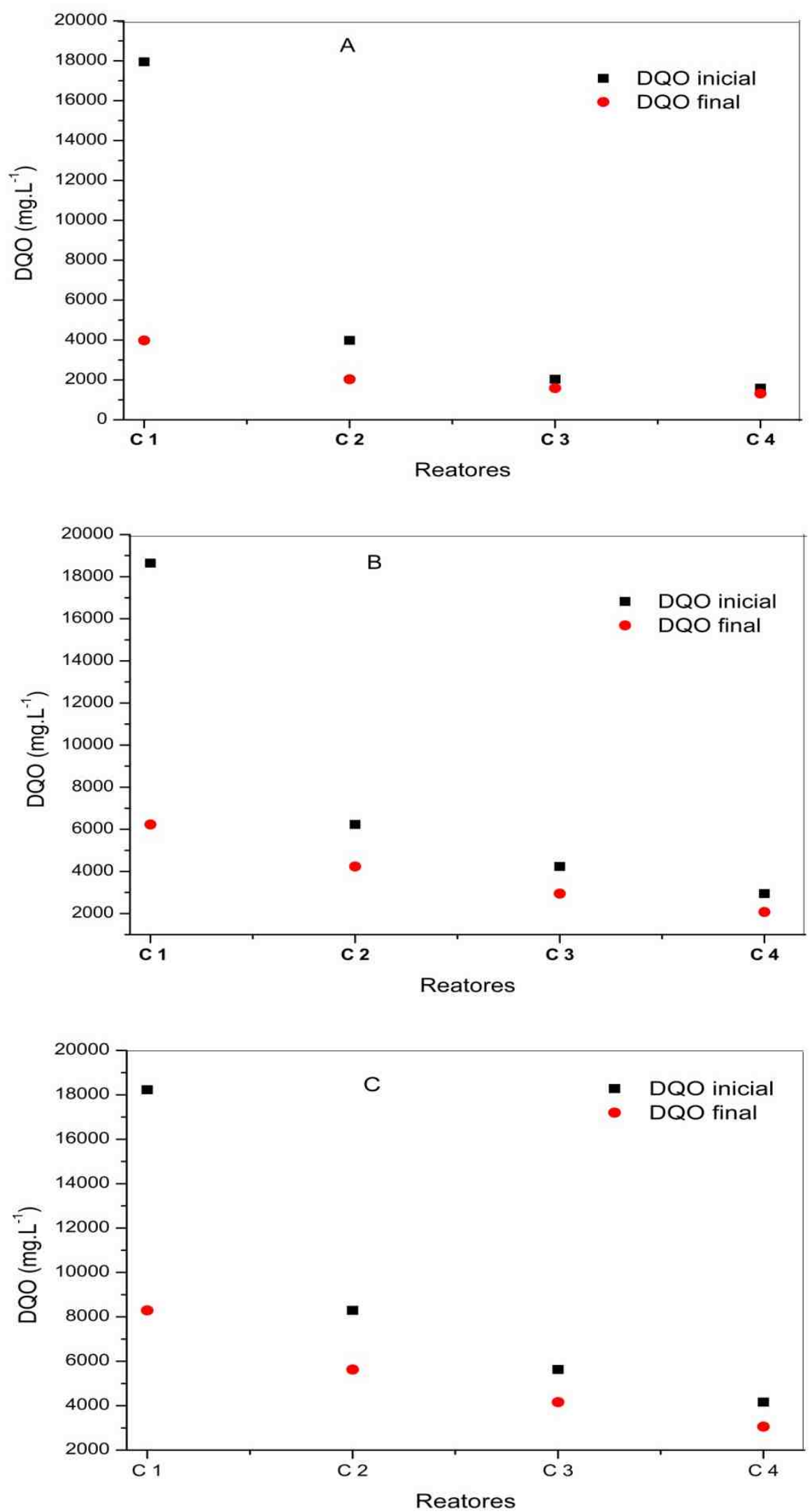

Figura 5.33 - Valores de DQO inicial e final obtida para as quatro câmaras nos ensaios em batelada sequencial. (A) Fase I; (B) Fase II e (C) Fase III. 

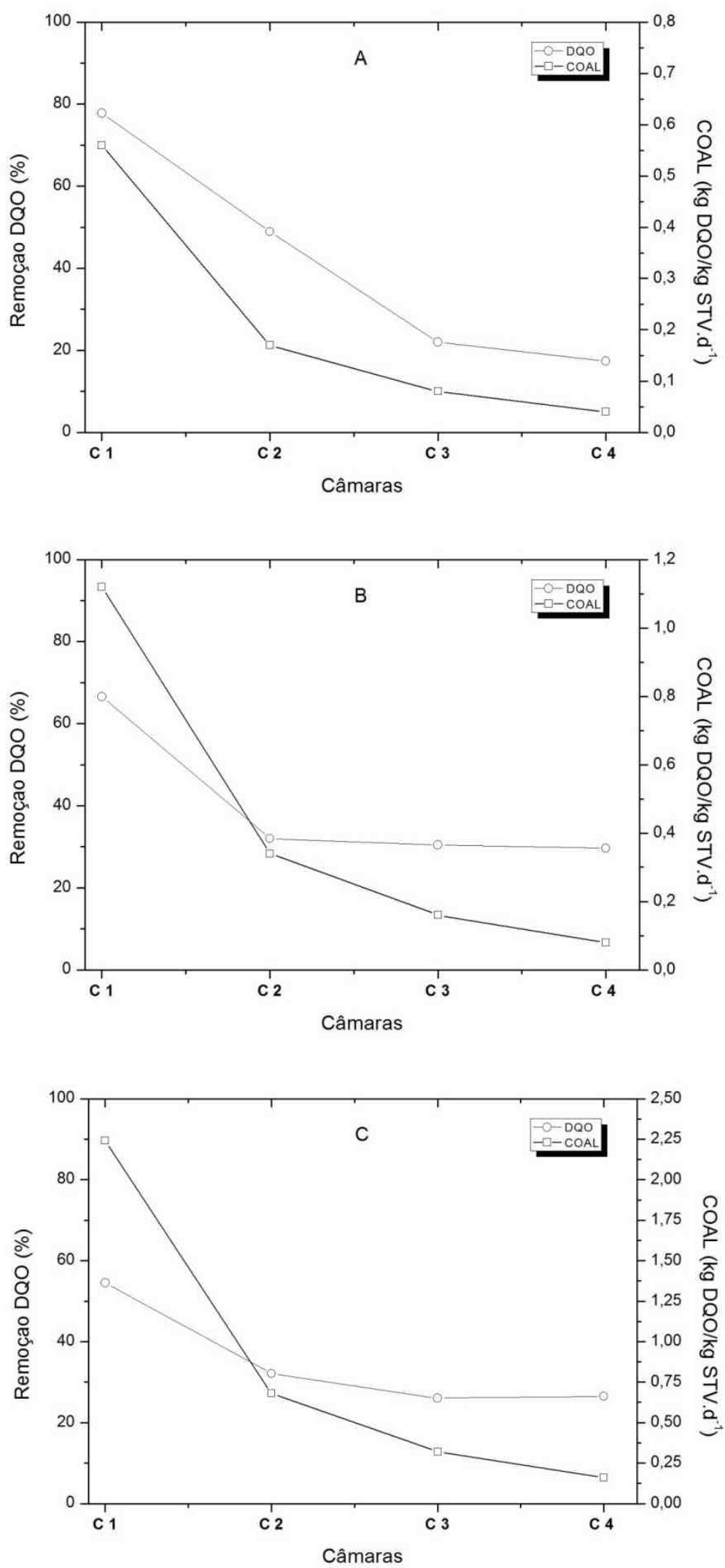

Figura 5.34 - Eficiências de remoção de DQO versus a COAL aplicada nos ensaios em batelada na Fase I (A), Fase II (B) e Fase III (C). 
Durante a operação dos reatores em batelada, a concentração média de DQO obtida para a vinhaça afluente do reator C1 (Figura 5.33) foi de $17.947 \pm 494,62 \mathrm{mg} . \mathrm{L}^{-1}$, $18.647 \pm 294,15 \mathrm{mg} . \mathrm{L}^{-1}$ e $18.231 \pm 120,55 \mathrm{mg} \cdot \mathrm{L}^{-1}$ para as Fases I, II e III, respectivamente, obtendo concentrações de DQO efluente de $3.985 \pm 115,56 \mathrm{mg} . \mathrm{L}^{-1}$; $6.232 \pm 92,31 \mathrm{mg} . \mathrm{L}^{-1}$ e $8.295 \pm 226,47 \mathrm{mg} . \mathrm{L}^{-1}$ para as Fases I, II e III, respectivamente.

Os valores de concentração de DQO bruta da vinhaça utilizados nos ensaios em batelada foram similares aos obtidos na alimentação do reator RAS em sistema contínuo, na primeira etapa do trabalho, resultado da manutenção das características qualitativas da mesma.

A partir da Figura 5.33 observa-se que, as menores concentrações de DQO efluente para os reatores $\mathrm{C} 1, \mathrm{C} 2, \mathrm{C} 3$ e $\mathrm{C} 4$, foram observadas para a Fase I, com a replicação dos valores de COAL de 0,56; 0,17; 0,08 e 0,04 kg DQO/kg STV.d ${ }^{-1}$, respectivamente, obtidas ao final da operação do reator RAS em sistema contínuo.

Em relação aos valores de eficiência de remoção de DQO obtidos na Fase I (Figura 5.34 A) esses foram da ordem de 77,8 \%, 48,9\%, 22,0 \% e 17,3\% para os reatores $\mathrm{C} 1, \mathrm{C} 2, \mathrm{C} 3$ e C4, respectivamente, obtendo-se eficiência global de remoção de $92,68 \%$.

Nas Fases II e III (Figura 5.33 B e 5.33 C), observou-se o aumento da concentração de DQO efluente para ambos os reatores, como resultado direto da elevação da COAL e cargas orgânicas aplicadas.

Para a Fase II, os valores médios de concentrações de DQO efluente foram de $6.232 \pm 391 \mathrm{mg} \cdot \mathrm{L}^{-1}, 4.238 \pm 130,34 \mathrm{mg} . \mathrm{L}^{-1}, 2.947 \pm 350,26 \mathrm{mg} . \mathrm{L}^{-1}$ e $2.074 \pm 194,63$ mg. $\mathrm{L}^{-1}$, para os reatores $\mathrm{C} 1, \mathrm{C} 2, \mathrm{C} 3$ e $\mathrm{C} 4$, obtendo-se percentuais de eficiências de remoção da ordem de $66,6 \% ; 32,0 \% ; 30,5 \%$ e $29,6 \%$, respectivamente, correspondendo a uma eficiência global de remoção de 88,9 \%. 
Quando comparada à Fase I, a eficiência de remoção de DQO obtida na Fase II (Figura 5.34 B) para os reatores C1 e C2 sofreu redução de pontos percentuais quando aplicada COAL de 1,12 e 0,34 kg DQO/kg STV.d ${ }^{-1}$, respectivamente, ao passo que, a elevação da COAL favoreceu o aumento da eficiência de remoção de DQO em C3 e C4, da ordem de $+8,5 \%$ e $+12,3 \%$, respectivamente.

Esse fato está relacionado à maior disponibilidade de substrato afluente em C3 e C4, resultado da concentração de matéria orgânica residual em termos de DQO efluente, provenientes dos reatores $\mathrm{C} 1$ e $\mathrm{C} 2$.

Para a Fase III, os valores médios de concentração de DQO afluente e efluente obtidos para C1, C2, C3 e C4 foram de 18231,00 \pm 71,42 e 8295,60 \pm 124,15 mg.L ${ }^{-1}$; $8295,60 \pm 124,15$ e $5629,10 \pm 91,30$ mg.L $\mathrm{L}^{-1} ; 5629,10 \pm 91,30$ e 4163,65 $\pm 115,72$ mg.L ${ }^{-}$ ${ }^{1}$; e 4163,65 $\pm 115,72$ e $3060,10 \pm 42,50 \mathrm{mg} . \mathrm{L}^{-1}$, respectivamente.

Em relação aos valores individuais de eficiência de remoção de DQO na Fase III, estes foram de $54,5 \%, 32,1 \%, 26,0 \%$ e $26,5 \%$ para $\mathrm{C} 1, \mathrm{C} 2, \mathrm{C} 3$ e $\mathrm{C} 4$, respectivamente, obtendo-se eficiência global de remoção da ordem de 83,2 \%.

Constata-se que, o aumento nos valores de COAL aplicadas nas Fases II e III, da ordem de $100 \%$ e $400 \%$, respectivamente, proporcionou ligeira redução de eficiência na remoção de DQO para os reatores $\mathrm{C} 1$ e C2, enquanto para C3 e C4 esse aumento foi favorecido. Tal acontecimento pode estar relacionado à sobrecarga orgânica imposta aos reatores repentinamente nestas fases, influenciando a "harmonia" do processo de digestão anaeróbia (Speece, 1992).

De modo geral, quando confrontados os valores de eficiência global de remoção de DQO obtidos nas três fases, nota-se ligeira tendência na redução do percentual de remoção de DQO de acordo com o aumento do carregamento orgânico aplicado ao lodo 
(COAL), implicando também, no aumento individual da carga orgânica (CO) aplicada em cada reator.

Ribas (2006) avaliando o tratamento de vinhaça de cana-de-açúcar em um reator anaeróbio mesofílico contendo biomassa imobilizada operado em bateladas sequenciais, submetido a cargas orgânicas de 2,$85 ; 6,4 ; 7,9 ; 10,5 ; 22,2 ;$ e $36,0 \mathrm{~kg}$ DQO$/ \mathrm{m}^{-3} . \mathrm{d}^{-1}$, obteve eficiências médias de remoção de DQO da ordem de 75, 76, 78, 78, 85 e 79\%, respectivamente. A autora ainda constatou que as quedas de eficiência observadas após os aumentos da COV eram prontamente superadas nas bateladas seguintes, mantendo a estabilidade operacional do reator.

Assim como constatado por Ribas (2006), o decaimento das eficiências de remoção de matéria orgânica com o aumento da carga orgânica aplicada neste estudo, principalmente nos reatores $\mathrm{C} 1$ e $\mathrm{C} 2$, foram recuperados posteriormente com o encaminhamento do efluente destes aos reatores $\mathrm{C} 3$ e $\mathrm{C} 4$, favorecido pela compartimentação sequencial do sistema.

Döll e Foresti (2010) avaliaram o desempenho de reator anaeróbio em batelada sequencial com biomassa imobilizada tratando vinhaça de cana de açúcar a $35^{\circ} \mathrm{C}$, submetido a variações de $\mathrm{COV}$ de 2,8 a $36,0 \mathrm{~g}$ DQO/L $\mathrm{L}^{-1} \cdot \mathrm{d}^{-1}$, conseguindo eficiência de remoção de DQO da ordem de 75 a $85 \%$, valores estes semelhantes aos obtidos neste estudo para as Fases II e III (89 e $83 \%$, respectivamente) em termos de eficiência de remoção global.

Nacheva et al. (2005) utilizando um reator anaeróbio de leito expandido no tratamento de vinhaça alcançaram remoção de DQO na faixa de 65 a $80 \%$ com aplicação de cargas orgânicas da ordem de 9 a $16 \mathrm{~g} \mathrm{DQO} / \mathrm{L}^{-1} \cdot \mathrm{d}^{-1}$.

Na Figura 5.35 e 5.36 são apresentados os valores de concentração e remoção de carboidratos, respectivamente, observados durante os ensaios em batelada. 

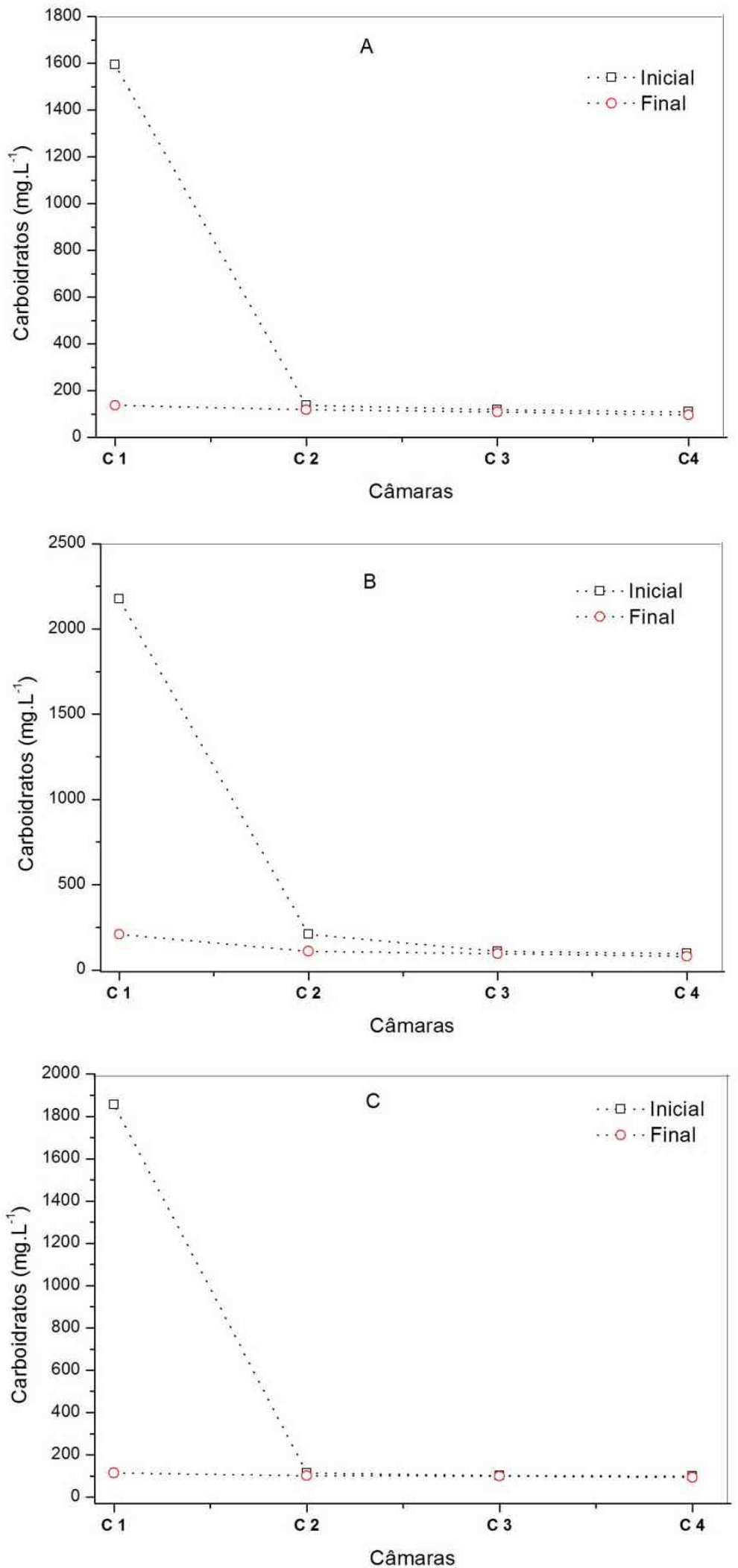

Figura 5.35 - Valores de concentração de carboidratos inicial e final obtida para as quatro câmaras nos ensaios em batelada sequencial. (A) Fase I; (B) Fase II e (C) Fase III. 

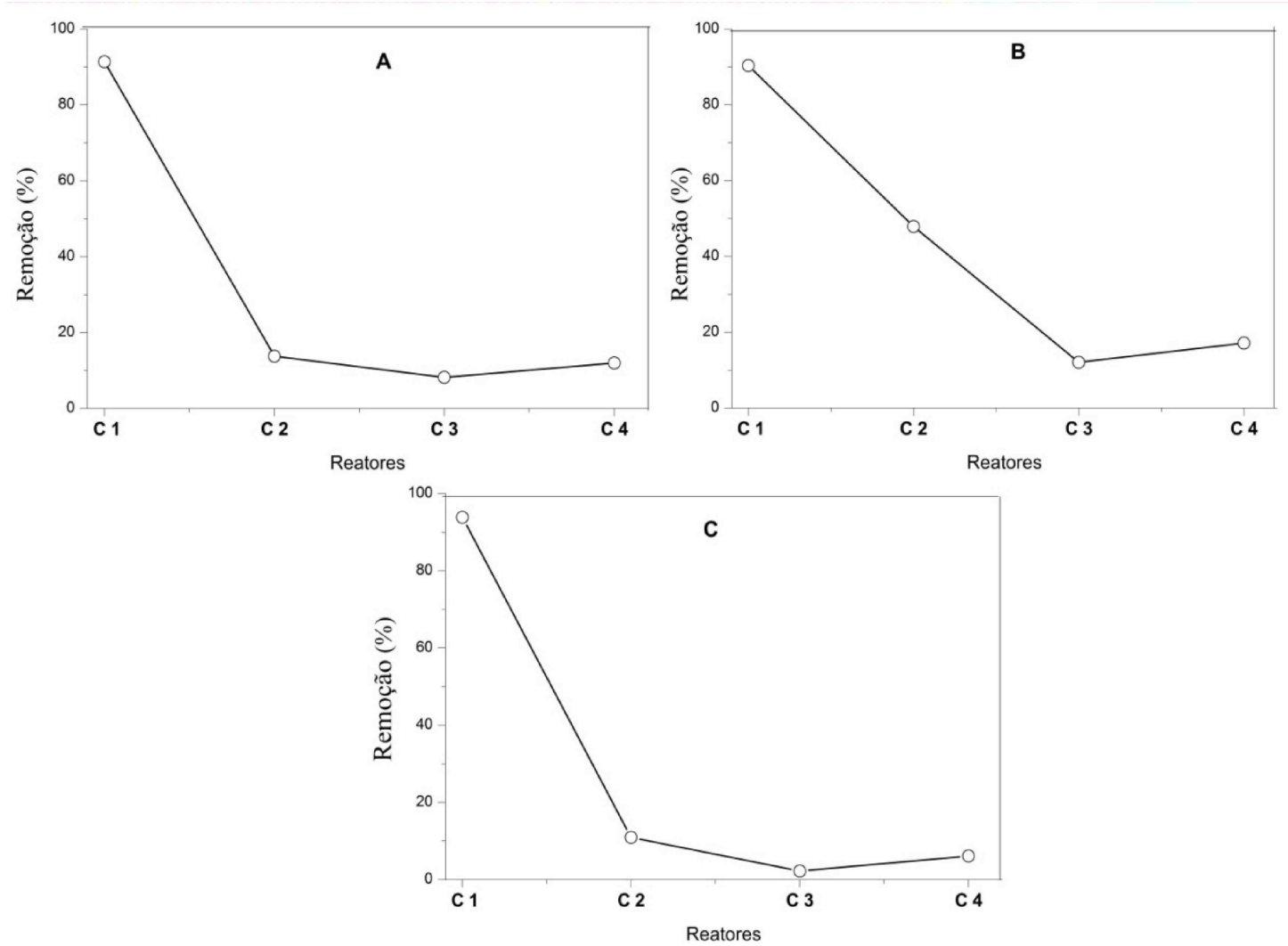

Figura 5.36 - Eficiência de remoção de carboidratos para as quatro câmaras nos ensaios em batelada sequencial. Fase I (A), Fase II (B) e Fase III (C).

Como observado para o monitoramento da concentração de DQO, a remoção de carboidratos foi efetiva para ambas as fases dos ensaios em batelada, obtendo-se percentuais de remoção global de 94,01 \% (Fase I), 96,3\% (Fase II) e 95,1 \% (Fase III).

Os valores de percentuais de remoção de carboidratos para C1, C2, C3 e C4, como ilustrado na Figura 5.36 foram de 91,4 \%, 13,8\%, 8,2\% e 12,1\% (Fase I); 90,4\%, $47,9 \%, 12,1 \%$ e $17,1 \%$ (Fase II), e $93,8 \%, 10,9 \%, 2,2 \%$ e $6,2 \%$ (Fase III), respectivamente.

Constata-se que as maiores remoções de carboidratos e, portanto, a parcela mais significativa, foi obtida pelo reator $\mathrm{C} 1$ para ambas as fases dos ensaios. Logo, os reatores $\mathrm{C} 2, \mathrm{C} 3$ e C4, pouco contribuíram em termos de remoção de carboidratos. 
Tal acontecido pode estar relacionado a predominância de microrganismos consumidores de carboidratos presentes em C1 (gênero T68), assim como observado nas análises de biologia molecular da primeira etapa do trabalho.

Observa-se que o aumento dos valores de COAL com o consequente aumento da carga orgânica, aparentemente não influenciou na redução dos valores de eficiência de remoção de carboidratos, principalmente para $\mathrm{C} 1$.

A Figura 5.37 apresenta os valores de pH obtidos no início e após os ensaios em batelada para as Fases I, II e III.

Inicialmente o $\mathrm{pH}$ das amostras de vinhaça utilizada nos ensaios foi fixado em 7 (neutro), utilizando solução de bicarbonato de sódio, visando a sua adequação para o processo de digestão anaeróbia.

Na Fase I (Figura 5.37 A), os valores de $\mathrm{pH}$ mantiveram-se praticamente constantes no decorrer do ensaio, oscilando entre 7,60 e 7,86 para C1 e C2, respectivamente.

Os valores de $\mathrm{pH}$ obtidos na Fase II foram de 7,9; 7,7; 7,8 e 7,8 para C1, C2, C3 e C4, respectivamente, enquanto para a Fase III estes foram da ordem de 7,9; 7,8; 7,9 e 7,7 para $\mathrm{C} 1, \mathrm{C} 2, \mathrm{C} 3$ e $\mathrm{C} 4$, respectivamente, observando-se o mesmo comportamento de neutralidade da Fase I.

De modo geral, observou-se que os valores de $\mathrm{pH}$ mantiveram-se dentro da faixa de neutralidade adequada para o processo de digestão anaeróbia, mesmo após o aumento brusco da carga orgânica aplicada nas Fases II e III. 

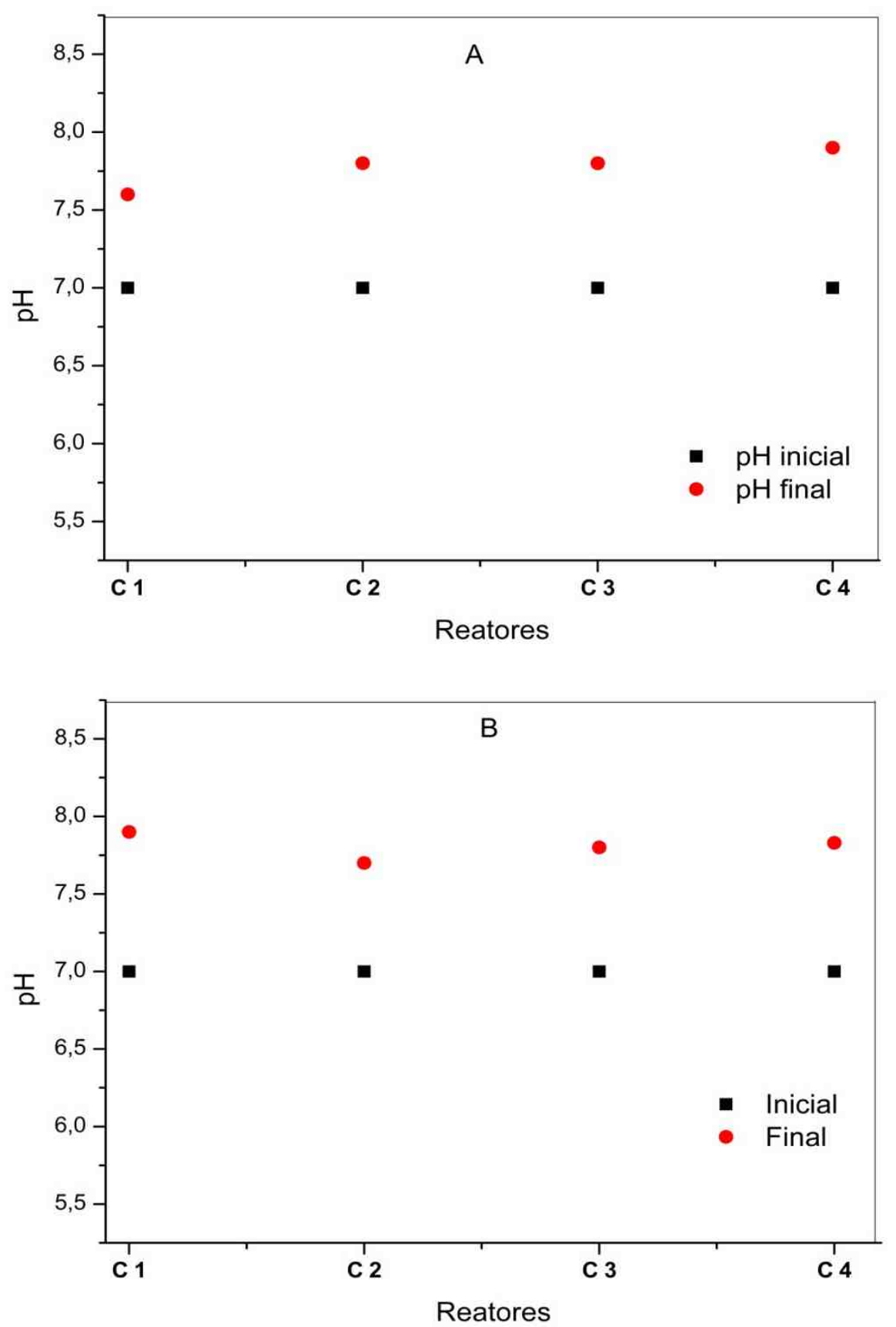

Figura 5.37 - Valores de pH inicial e final obtidos para as quatro câmaras nos ensaios em batelada sequencial. (A) Fase I; (B) Fase II e (C) Fase III. 


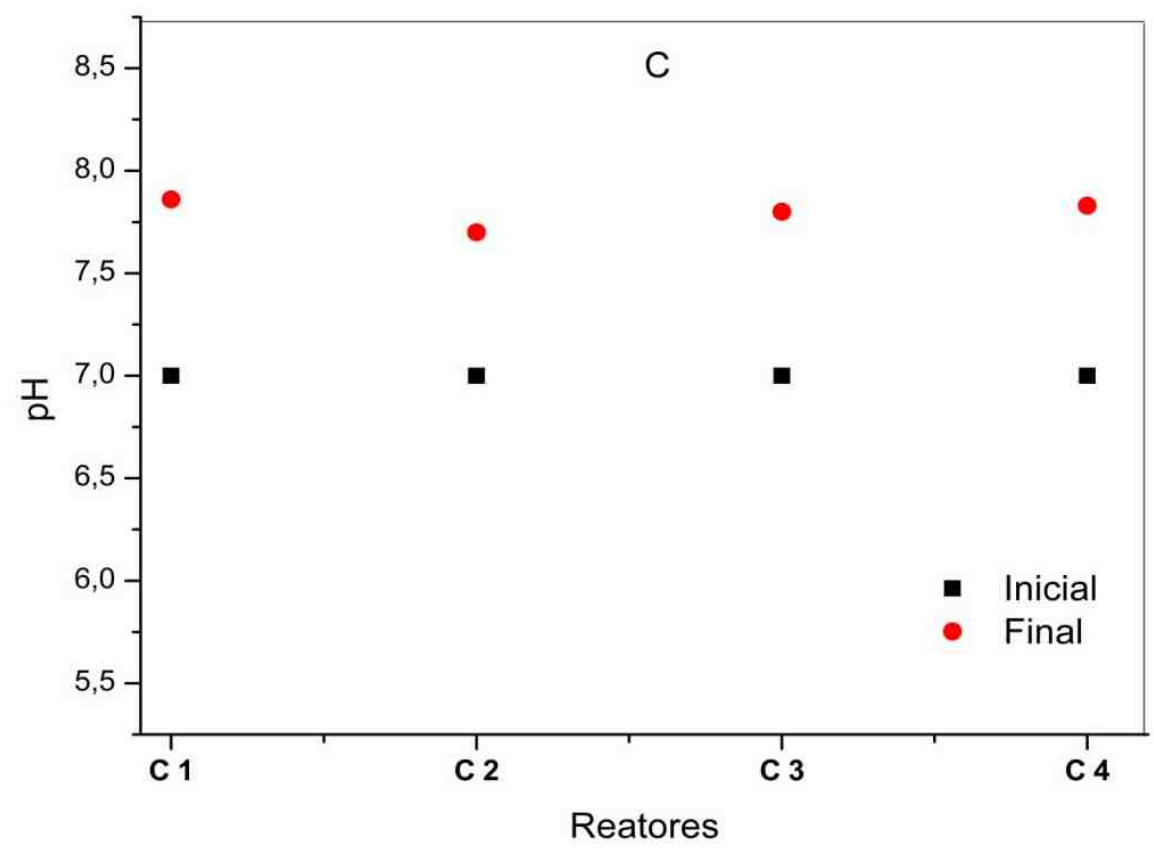

Figura 5.37 - Valores de pH inicial e final obtidos para as quatro câmaras nos ensaios em batelada sequencial. (A) Fase I; (B) Fase II e (C) Fase III. (Continuação).

Os ácidos orgânicos voláteis também denominados de ácidos graxos voláteis (AGV), tais como ácido acético, propiônico e butírico, são importantes metabólitos e intermediários no processo de digestão anaeróbia (Chernicharo, 1997), sendo propício o seu monitoramento no tratamento de águas residuárias complexas, tal como a vinhaça de cana-de-açúcar, visando melhorias na produção de metano.

Os valores obtidos do monitoramento de ácidos orgânicos voláteis (acético, propiônico e butírico) nas Fases I, II e II são apresentados na Figura 5.38.

Observam-se, a partir da Figura 5.38, distintos comportamentos na concentração de ácidos orgânicos voláteis para os quatro reatores ao longo das três fases do ensaio em batelada.

Na Fase I (Figura 5.38 A), as maiores concentrações de ácido acético, propiônico e butírico foram verificadas para o efluente do reator $\mathrm{C} 1$, da ordem de 395,06 $\pm 128,87$ mg. $\mathrm{L}^{-1}, 14,51 \pm 0,76 \mathrm{mg} . \mathrm{L}^{-1}$ e $34,27 \pm 11,05 \mathrm{mg} . \mathrm{L}^{-1}$, respectivamente. Para os demais 
reatores, as concentrações de ácido acético, propiônico e butírico obtidas foram de $55,57 \pm 21,76 \mathrm{mg} . \mathrm{L}^{-1}, 11,20 \pm 2,29 \mathrm{mg} . \mathrm{L}^{-1}$ e $9,81 \pm 0,58 \mathrm{mg} . \mathrm{L}^{-1}$ (reator C 2); 94,64 \pm 15,46 mg.L $\mathrm{L}^{-1}$, 32,72 \pm 8,05 mg. $\mathrm{L}^{-1}$ e 18,23 \pm 6,90 mg. $\mathrm{L}^{-1}$ (reator C 3); e 87,27 $\pm 35,12$ mg. $\mathrm{L}^{-1}, 35,66 \pm 22,25 \mathrm{mg} . \mathrm{L}^{-1}$ e $11,32 \pm 1,72 \mathrm{mg} . \mathrm{L}^{-1}$ (reator C 4), respectivamente.

Os valores de ácidos obtidos na Fase I corroboram com os resultados verificados ao final da operação contínua do reator RAS (Etapa 1), tendo em vista que se trata da replicação de valores similares da COAL.

Posteriormente, nos ensaios da Fase II (Figura 5.38 B) observou-se o aumento significativo da concentração de ácido acético para o efluente do reator C1 (1420,79 \pm 11,14 mg. $\left.\mathrm{L}^{-1}\right)$, decorrente do aumento da COAL de 0,56 para 1,12 kg DQO/kg STV.d ${ }^{-1}$. 

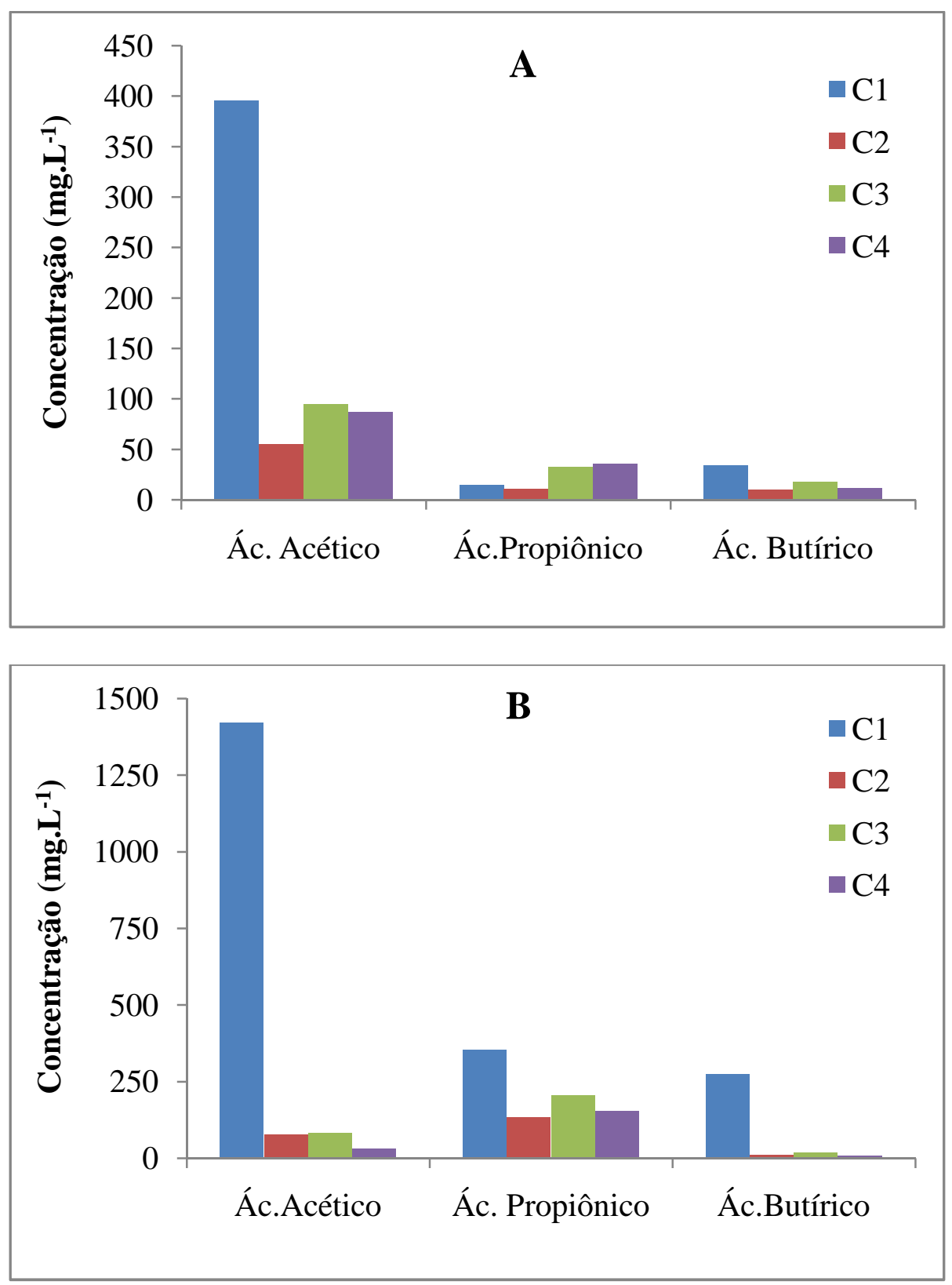

Figura 5.38 - Valores de concentração de ácidos graxos voláteis (AGV) obtidos para as quatro câmaras nos ensaios em batelada sequencial. (A) Fase I; (B) Fase II e (C) Fase III. 


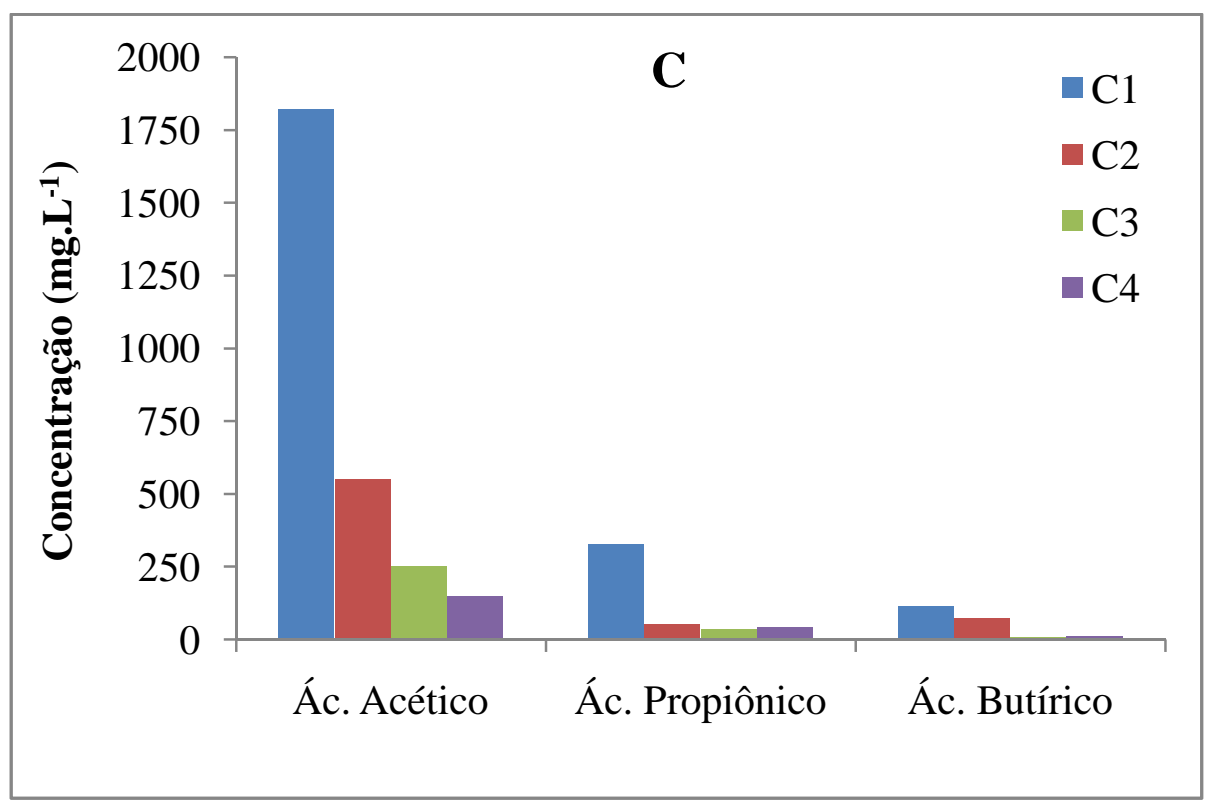

Figura 5.38 - Valores de concentração de ácidos graxos voláteis (AGV) obtidos para as quatro câmaras nos ensaios em batelada sequencial. (A) Fase I; (B) Fase II e (C) Fase III. (Continuação).

O aumento da carga orgânica pode vir a ocasionar na maior produção de ácidos orgânicos, em função do aumento da degradação de carboidratos e matéria orgânica, como observados neste estudo (Speece, 1996; Metcalf \& Eddy, 2003).

Para os reatores C2, C3 e C4 operados na Fase II, as concentrações médias de ácido acético, propiônico e butírico foram de 76,86 \pm 9,84 mg. $\mathrm{L}^{-1}, 133,77 \pm 31,15 \mathrm{mg} . \mathrm{L}^{-}$ ${ }^{1}$ e $10,43 \pm 0,68 \mathrm{mg} . \mathrm{L}^{-1}$ (C 2); 83,82 $\pm 37,51 \mathrm{mg} . \mathrm{L}^{-1}, 204,49 \pm 44,44 \mathrm{mg} \cdot \mathrm{L}^{-1}$ e $19,46 \pm$ 7,01 mg. $\mathrm{L}^{-1}$ (C 3); e 29,15 \pm 15,96 mg.L $\mathrm{L}^{-1}, 154,75 \pm 13,43 \mathrm{mg} . \mathrm{L}^{-1}$ e 7,76 \pm 1,97 mg.L $\mathrm{L}^{-1}$ (C 4), respectivamente.

Em relação à Fase III, novamente observou-se o aumento das concentrações de ácido acético $\left(1819,76 \pm 24,78 \mathrm{mg} \cdot \mathrm{L}^{-1}\right)$, propiônico $\left(327,54 \pm 55,14 \mathrm{mg} . \mathrm{L}^{-1}\right)$ e butírico $\left(112,04 \pm 14,01 \mathrm{mg} . \mathrm{L}^{-1}\right)$ em C1, quando elevada a COAL de 1,12 para 2,24 kg DQO.kg STV/d. Verificou-se também que, mesmo após o aumento de COAL, as cargas 
orgânicas obtidas nas Fases II e III, foram muito semelhantes, da ordem de 20,52 e 20,05 kg DQO.d, respectivamente.

As concentrações de ácido acético, propiônico e butírico observadas para C2, C3 e C4 na Fase III, também foram ligeiramente superiores em comparação as fases anteriores.

O desbalanceamento inicial entre a produção e o consumo de ácidos orgânicos observados, pode estar relacionado ao decaimento mais rápido da população de microrganismos metanogênicos, por crescer mais lentamente que as populações hidrolíticas e fermentativas (Pohland e Chosh, 1971).

De acordo com Sawyer e McCarty (1978) o acúmulo de ácidos voláteis pode ter um efeito deletério sobre a digestão anaeróbia se a capacidade de tamponamento for extrapolada e o $\mathrm{pH}$ decrescer para níveis desfavoráveis. No entanto, mesmo com o acúmulo de ácido acético pelo reator $\mathrm{C} 1,3,6$ vezes maior quando comparado à Fase I, por exemplo, não foi constatado o decréscimo dos valores de $\mathrm{pH}$ e a inibição do processamento anaeróbio da vinhaça, em virtude da biomassa já estar aclimatada.

De maneira geral, constatou-se que o excesso de ácidos orgânicos produzidos inicialmente no reator $\mathrm{C} 1$ e não prontamente consumidos pela biomassa microbiana, são acumulados e posteriormente encaminhados para os demais reatores subsequentes $(\mathrm{C} 2$, C3 e C4). O aumento na concentração de ácidos graxos observados se deve a imposição do aumento do carregamento orgânico aplicado nas fases II e III.

Esses ácidos voláteis são formados tão imediatamente como durante a degradação efetiva de carboidratos (Figura 5.36). No entanto, decorrente da elevação da COAL, da carga orgânica obtida, do tempo de ciclo (TDH) e da não especialização dos grupos microbianos predominantes na biomassa dos reatores $\mathrm{C} 2, \mathrm{C} 3$ e $\mathrm{C} 4$, esses ácidos 
orgânicos em excesso, não são totalmente degradados e convertidos diretamente à gás metano e dióxido de carbono.

Segundo Speece (1996), o equilíbrio do processo anaeróbio é evidenciado por uma série de complexas reações bioquímicas, realizada por diferentes classes de organismos que processam os ácidos orgânicos intermediários tão rapidamente quanto são produzidos. No entanto, uma vez que os processos microbianos se desenvolvem sob taxa proporcional à concentração de substrato disponível, o acúmulo de substrato pode resultar na não capacidade de processar esses ácidos tão rapidamente quanto são produzidos.

A estratégia inicial de tamponar a vinhaça de cana-de-açúcar com solução de bicarbonato de sódio, antes de serem submetidas aos ensaios em batelada, bem como a geração de ácido acético verificada, muito provavelmente, favoreceu a manutenção e equilíbrio da etapa de metanogênese, e concomitante a produção de biogás com teor de metano elevado, como pode ser constatado no item 5.2.2.

Em análises comparativas entre as Fases I, II III observa-se que, os valores de COAL aplicada aos reatores, resultaram em distintas concentrações de ácidos orgânicos voláteis, influenciando na produção de metano e composição do biogás, descritos no item a seguir.

\subsubsection{Produção de metano e composição do biogás}

Os dados referentes à produção de metano e composição do biogás obtido para os reatores $\mathrm{C} 1, \mathrm{C} 2, \mathrm{C} 3$ e C4 no decorrer das três fases dos ensaios descontínuos, são apresentados nas Figuras 5.39 e 5.40, respectivamente. 


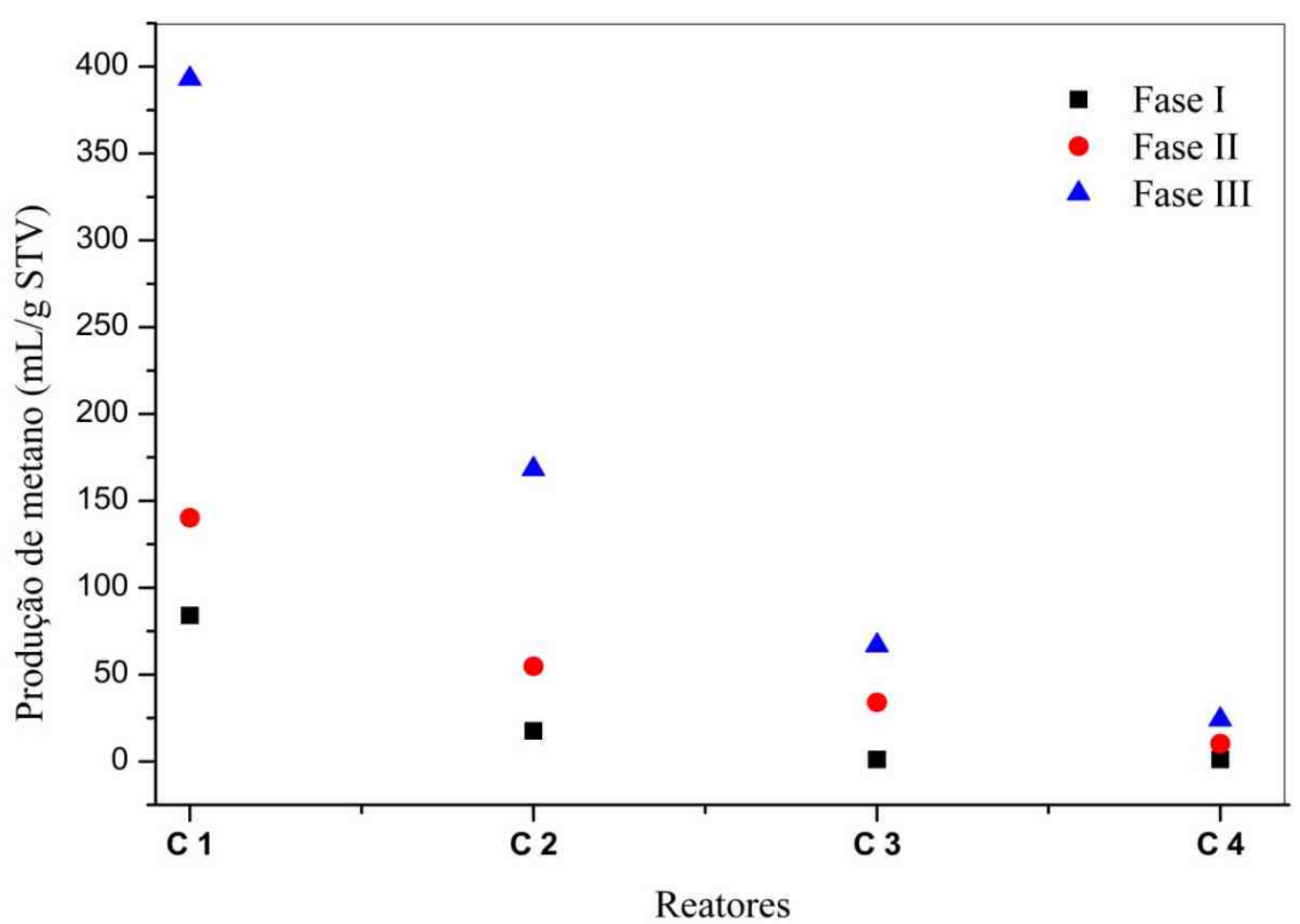

Figura 5.39 - Produção volumétrica de metano obtida para os reatores operados em sistema descontínuo.

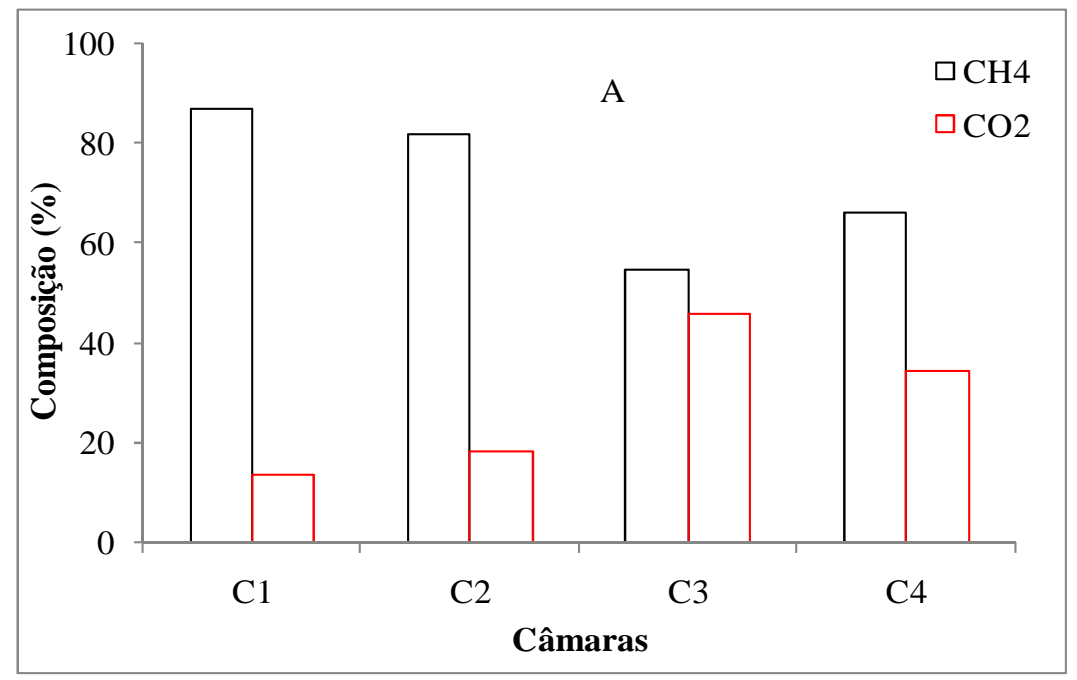

Figura 5.40 - Composição do biogás obtida para os reatores operados em sistema descontínuo. Fase I (A); Fase II (B) e Fase III (C). 

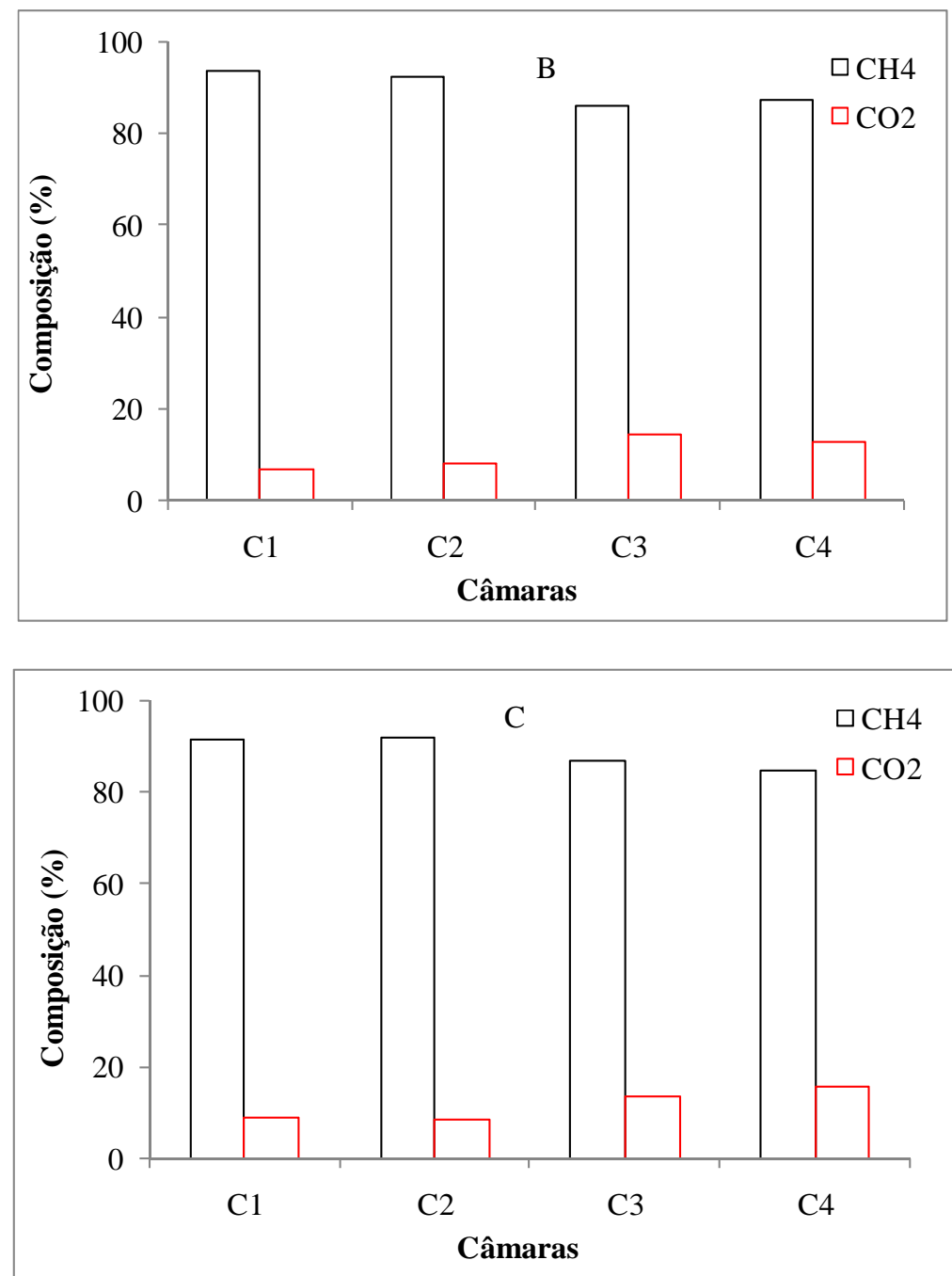

Figura 5.40 - Composição do biogás obtida para os reatores operados em sistema descontínuo. Fase I (A); Fase II (B) e Fase III (C). (Continuação).

Como constatado anteriormente, os diferentes comportamentos na remoção de matéria orgânica na forma de DQO e na geração de ácidos graxos orgânicos nas Fases I, II e III, decorrentes dos valores de COAL, exerceu influência na produção de metano e na composição do biogás.

Os resultados dos ensaios em batelada confirmam que as maiores parcelas de matéria orgânica removida e concomitante produção de metano, foram conseguidas pelo reator C1 (Figura 5.39), outrossim, como constatado na operação contínua do reator RAS na Etapa 1. 
Em comparação com $\mathrm{C} 1$, os reatores $\mathrm{C} 2, \mathrm{C} 3$ e $\mathrm{C} 4$ exerceram a função de unidades de polimento na degradação da matéria orgânica, principalmente $C 3$ e $C 4$, verificando consequentemente nestas, decréscimo na produção de metano.

A produção volumétrica de metano obtida em C1 ao longo das Fases I, II e III foi

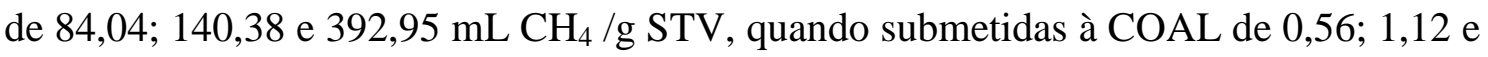
$2,24 \mathrm{~kg} \mathrm{DQO} / \mathrm{kg} \mathrm{STV} . \mathrm{d}^{-1}$, respectivamente.

Para os reatores C2, C3 e C4 os valores de produção de metano obtidos foram de 17,57; 1,14 e 1,12 $\mathrm{mL} \mathrm{CH}_{4} / \mathrm{g} \mathrm{STV}$ (Fase I), 54,74; 34,03 e 10,24 $\mathrm{mL} \mathrm{CH}_{4} / \mathrm{g}$ STV (Fase II) e, 168,$33 ; 66,76$ e $24,14 \mathrm{~mL} \mathrm{CH}_{4} / \mathrm{g}$ STV (Fase III), respectivamente.

Os valores menores relativos à produção de metano obtidos em $\mathrm{C} 2, \mathrm{C} 3$ e C4, foram resultado da carga orgânica aplicada, tendo em vista que, quando elevado os valores de COAL e, por conseguinte elevação da CO aplicada nas Fases II e III em $100 \%$ e $400 \%$, respectivamente, os valores conseguidos para a produção de metano foram superiores (Figura 5.39).

Em relação à composição do biogás produzido, o teor de metano observado foi elevado para todos os reatores e fases dos ensaios. Como se pode observar a partir das Figuras 5.40 B e 5.40 C, o aumento dos valores de COAL aplicados nas Fases II e III, favoreceu o aumento da concentração de metano presente no biogás.

Os percentuais de metano e $\mathrm{CO}_{2}$ obtidos na Fase I (Figura 5.40 A) foram de $86,6 \%$ e $13,4 \%$ para $\mathrm{C} 1 ; 81,7 \%$ e $18,3 \%$ para $\mathrm{C} 2 ; 54,5 \%$ e $45,5 \%$ para $\mathrm{C} 3$ e; $65,8 \%$ e $34,2 \%$ para $\mathrm{C} 4$, respectivamente.

$\mathrm{Na}$ Fase II, os percentuais de metano obtidos para $\mathrm{C} 1, \mathrm{C} 2, \mathrm{C} 3$ e $\mathrm{C} 4$ foram de $93,3 \%, 92,1 \%, 85,8 \%$ e $87,8 \%$, respectivamente, enquanto para $\mathrm{CO}_{2}$ estes foram de 6,7\%, 7,9\%, 14,2\% e 12,7\%, respectivamente. Para a Fase III (Figura $5.40 \mathrm{C}$ ) os percentuais de metano conseguidos foram de $91,4 \%, 91,8 \%, 86,7 \%$ e $84,5 \%$ para os 
reatores $\mathrm{C} 1, \mathrm{C} 2, \mathrm{C} 3$ e $\mathrm{C} 4$, respectivamente, enquanto para $\mathrm{CO}_{2}$ estes foram de $8,8 \%$ (C1), $8,2 \%(\mathrm{C} 2), 13,3 \%(\mathrm{C} 3)$ e $15,5 \%(\mathrm{C} 4)$.

As maiores concentrações de metano presente no biogás foram evidenciadas para C1 e C2 na Fase II. No entanto, obtiveram-se concentrações significativas de metano para os demais reatores em ambas as fases dos ensaios.

Dentre os fatores que podem ter influenciado os bons resultados de concentração de metano presente no biogás, pode-se citar o tamponamento da vinhaça, favorecendo a estabilidade do processo metanogênico; e a transferência de massa, por meio do constante contato entre substrato/biomassa, decorrente de constante agitação dos frascos reatores ao longo do tempo de ciclo de 48 horas.

Como constatado na Etapa 1 do trabalho, os resultados obtidos dos ensaios descontínuos evidenciaram que a operação dos reatores em sistema serial (compartimentação) é responsável pela produção de biogás com maior concentração de metano, como resultado da carga orgânica aplicada a cada uma das câmaras (reatores).

\subsubsection{Diversidade da comunidade microbiana dos reatores ASBR}

Os resultados de DGGE obtidos comparativamente para as Fases I, II e III após a operação dos reatores $\mathrm{C} 1, \mathrm{C} 2, \mathrm{C} 3$ e $\mathrm{C} 4$ em batelada mostram que houve alteração na diversidade microbiana para ambos os domínios Bacteria e Archaea.

Na Figura 5.41 é apresentado o dendograma obtido para o domínio Bacteria por meio do perfil das bandas de DGGE, das amostras dos reatores nos ensaios em batelada sequencial para as Fases I, II e III. 


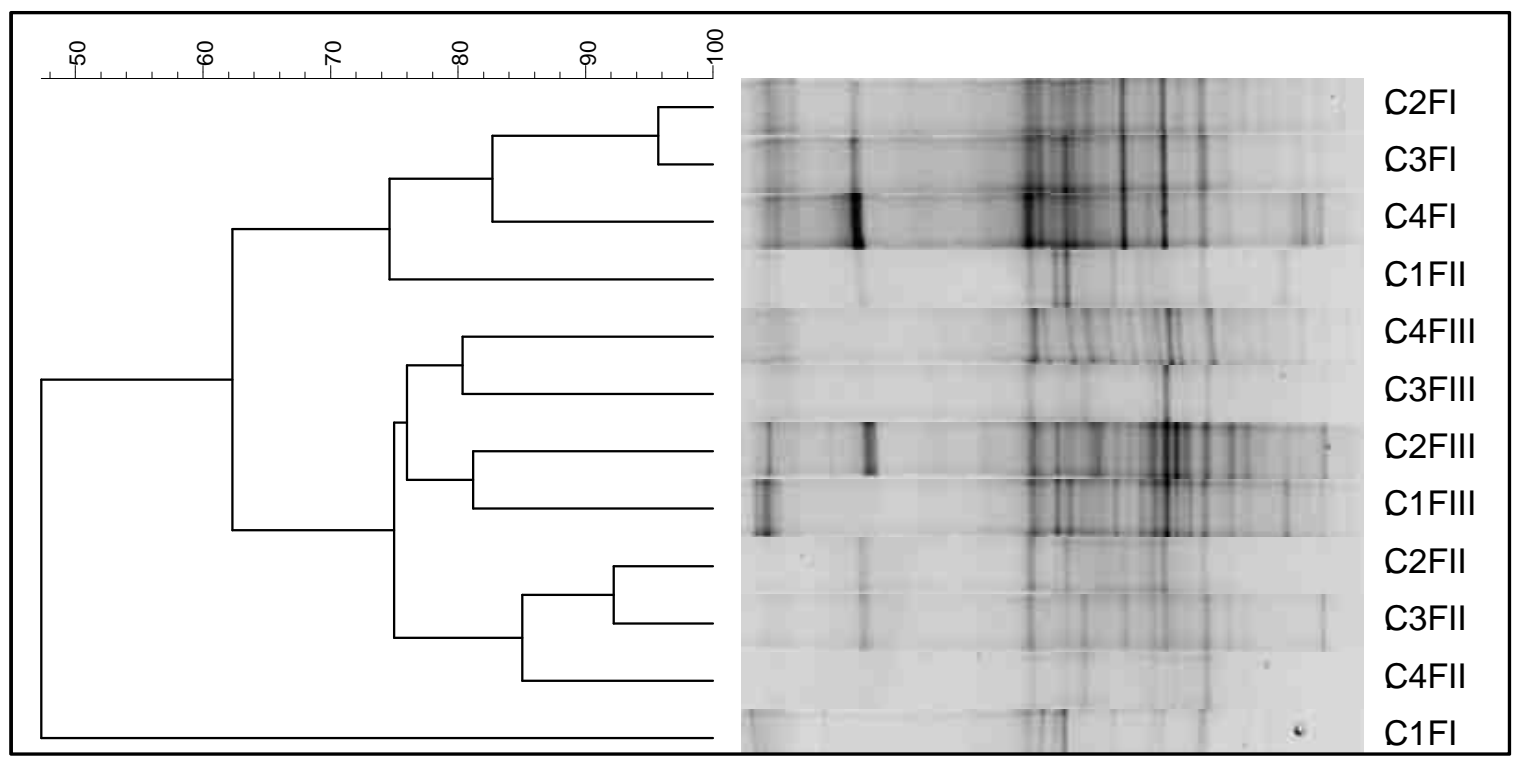

Figura 5.41 - Dendograma (UPGMA) obtido a partir do perfil das bandas de DGGE para o domínio Bacteria após os ensaios em batelada sequencial.

Com o aumento dos valores de COAL, ou seja, nas Fases I, II e III, o coeficiente de similaridade (CS) entre as populações bacterianas, variou entre os reatores $\mathrm{C} 1, \mathrm{C} 2$, C3 e C4. O coeficiente de similaridade na Fase I variou de 47\% - 96\%, na Fase II diferiram de $63 \%$ a $92 \%$ e na Fase III variou de $76 \%$ a $81 \%$ entre $\mathrm{C} 1$ a C4.

$\mathrm{Na}$ Fase I a comunidade bacteriana teve menor similaridade (47\%) para $\mathrm{C} 1 \mathrm{em}$ relação aos demais reatores $(\mathrm{C} 2, \mathrm{C} 3$ e $\mathrm{C} 4)$, mostrando que a biomassa não estava adaptada ao sistema. Enquanto, a maior similaridade (96\%) ocorreu entre C2 e C3, indicando que as populações bacterianas foram selecionadas e adaptadas a essa carga orgânica aplicada ao lodo (0,17 e 0,08 g DQO/g STV, respectivamente).

Para a Fase II o comportamento da população de bactéria foi semelhante à Fase I (Figura 5.41), ou seja, menor similaridade (62\%) no reator C1 (COAL de 1,12 g DQO/g STV) em relação as outros, e a maior semelhança (92\%) foi entre C2 e C3 (COAL de 0,34 e 0,16 g DQO/g STV, respectivamente). 
Na Fase III a população de baterias teve comportamento diferente em relação às fases anteriores I e II, com maior semelhança entre C1 e C2 (81\%), está relacionada com a maior quantidade de biomassa adaptada usada nesses compartimentos nessa fase. Vale lembrar que a biomassa usado nesse experimento foi provenientes do reator RAC operado por 280 dias na Etapa 1 do trabalho.

Na Figura 5.42 é apresentada a correlação entre os índices de diversidade Shannon e a dominância obtida para o domínio Bacteria das amostras analisadas nas Fases I, II e III.

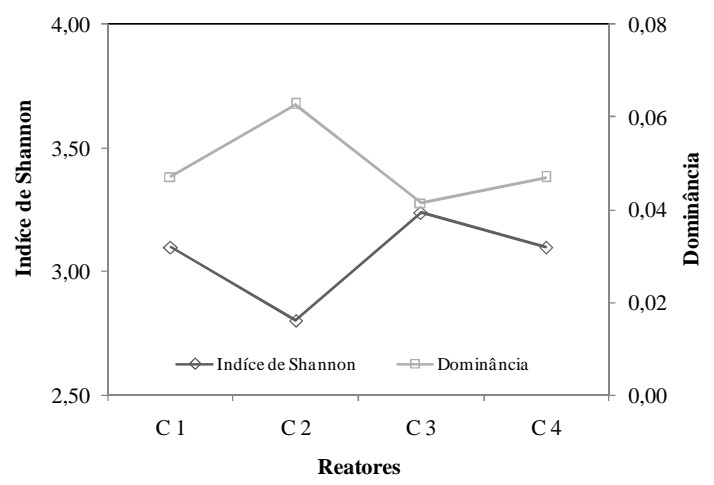

(a)

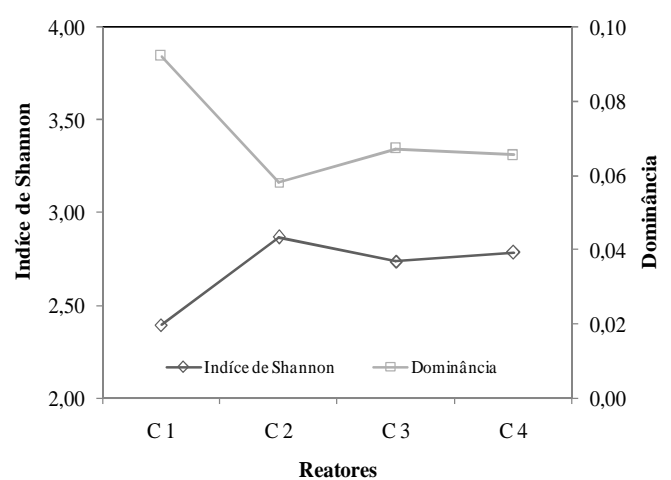

(b)

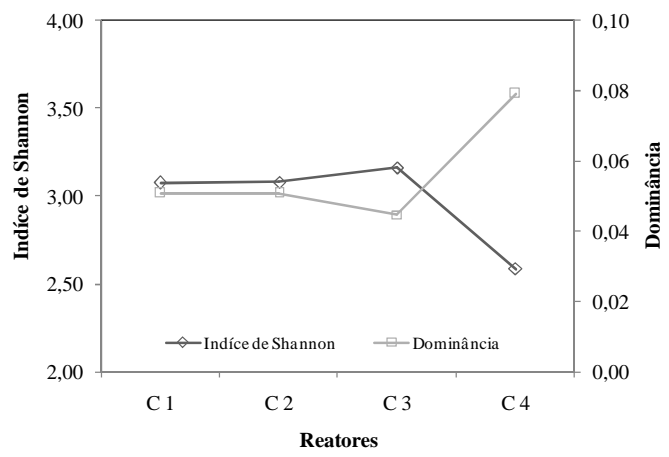

(c)

Figura 5.42 - Correlação do Índice de diversidade Shannon e a dominância para o grupo Bacteria obtidos nos ensaios em batelada para a Fase I (a), Fase II (b) e Fase III (c). 
A diversidade bacteriana teve comportamento diferente em relação às diferentes cargas orgânicas aplicadas ao lodo, ou seja, Fases I, II e III (Figura 5.42). O índice de diversidade variou, na Fase I de 2,80 a 3,23, na Fase II de 2,39 a 2,86, e para a Fase III de 2,58 a 3,16 .

Constata-se que, quando o índice de diversidade de Shannon reduz verifica-se o aumento da dominância, indicando provavelmente a adaptação de algumas populações às condições operacionais impostas ao sistema, para domínio Bacteria, principalmente nas Fases I e III para o reator C4.

Na Figura 5.43 é apresentado o dendograma obtido para o domínio Archaea por meio do perfil das bandas de DGGE, das amostras dos reatores nos ensaios em batelada sequencial para as Fases I, II e III.

Com o aumento dos valores de COAL, ou seja, nas Fases I, II e III, a estrutura da comunidade de arqueias teve pouca variação entre os quatro reatores operados em batelada sequencial. O coeficiente de similaridade na Fase I variou de $84 \%$ a 97\%, na Fase II diferiram de $90 \%$ a $97 \%$, e na Fase III variou de $62 \%$ a $95 \%$ entre os reatores $\mathrm{C} 1$ a $\mathrm{C} 4$, respectivamente. 


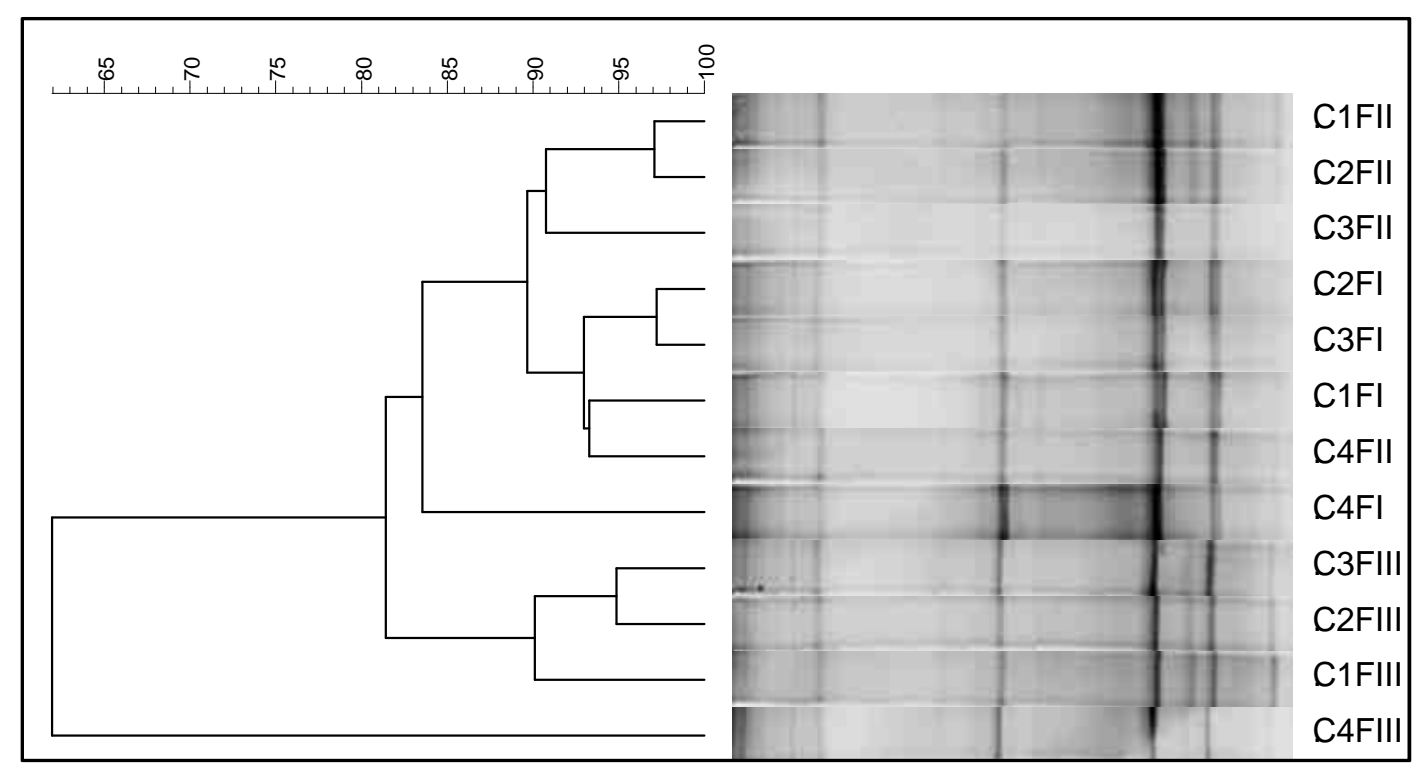

Figura 5.43 - Dendograma (UPGMA) obtido a partir do perfil das bandas de DGGE para o domínio Archaea após os ensaios em batelada sequencial.

Na Fase I a população de arqueias teve menor similaridade (84\%) no C4 em relação aos demais reatores (C1, C2 e C3), assim como na Fase II (90\%) e Fase III (62\%). Ressaltando que a menor similaridade do C4 ocorreu na Fase III, o qual a carga orgânica aplicada ao lodo foi maior (0,16 g DQO/g STV), sugerindo que houve uma seleção dos grupos de arqueias.

A Figura 5.44 apresenta a correlação entre os índices de diversidade Shannon e a dominância obtida para o domínio Archaea das amostras analisadas nos ensaios em batelada para as Fases I, II e III. 


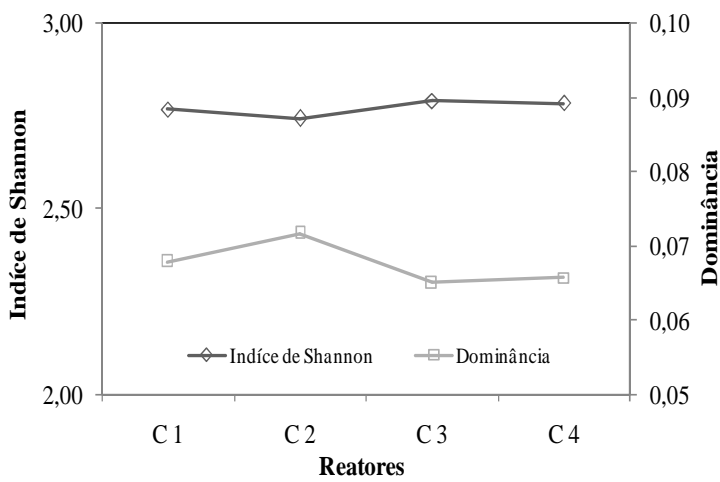

(a)

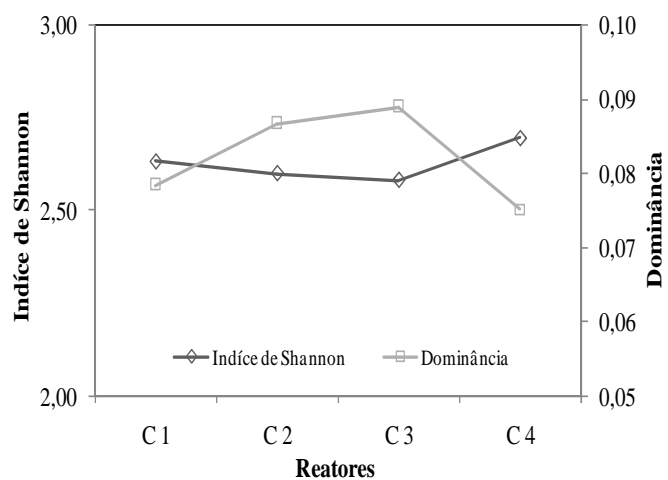

(b)

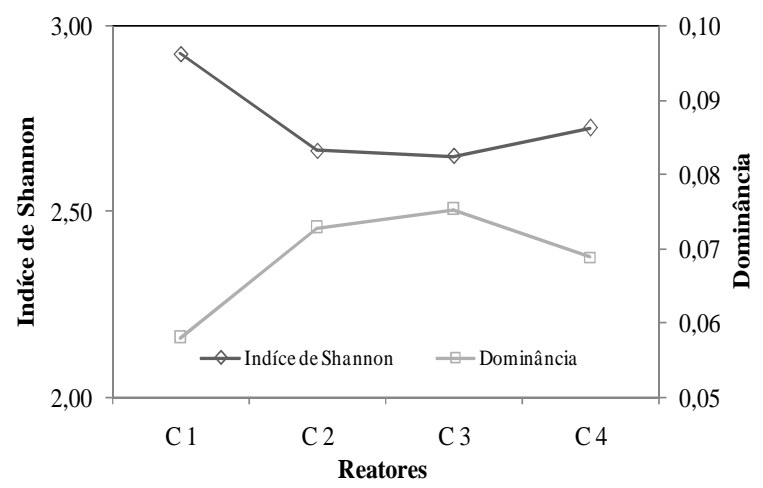

(c)

Figura 5.44 - Correlação do Índice de diversidade Shannon e a dominância para o grupo Archaea obtidos nos ensaios em batelada para a Fase I (a), Fase II (b) e Fase III (c).

A diversidade de arqueias e a dominância tiveram comportamento diferente em relação às cargas orgânica aplicada ao lodo ao longo das Fases I, II e III (Figura 5.44). Na Fase I verifica-se a manutenção da diversidade de arqueias entre os quatros reatores (2,74 a 2,78), na Fase II observa-se pequeno aumento em C4 (2,58 foi para 2,69), na Fase III a diversidade mais elevada foi obtida em C1 $(2,92)$ com maior valor de COAL (2,24 g DQO/g STV), e menor dominância (0,05789).

Constata-se que, quando o índice de diversidade de Shannon reduz verifica-se o aumento da dominância, indicando provavelmente a adaptação de algumas populações 
às condições de restrição nutricional, para domínio Archaea, principalmente nas Fases II e III dos reatores $\mathrm{C} 1$ e $\mathrm{C} 4$.

\subsection{ANÁLISE ESTATÍSTICA}

Neste tópico são apresentados os resultados obtidos do tratamento estatístico empregando o teste de análise de variância (ANOVA) utilizando o software STATISTICA $^{\circledR} 13$.

Para tanto, foram investigadas a significância das variáveis independentes COV (Etapa 1) e COAL (Etapa 2), na eficiência de remoção de DQO e na produção de metano, ao longo do período de operação do reator RAS e dos ensaios em batelada, respectivamente.

As hipóteses adotadas para o teste estatístico, considerando-se um nível de significância de $95 \%$ (p-valor $\leq 0,05$ ) foram:

$$
\begin{aligned}
& \mathrm{H}_{0} \text { : As médias obtidas em } \mathrm{C} 1=\mathrm{C} 2=\mathrm{C} 3=\mathrm{C} 4 \text {. } \\
& \mathrm{H}_{\mathrm{A}} \text { : As médias obtidas em } \mathrm{C} 1 \neq \mathrm{C} 2 \neq \mathrm{C} 3 \neq \mathrm{C} 4 .
\end{aligned}
$$

Antes de proceder à análise de variância, foram construídos diagramas de dispersão para os dados obtidos do monitoramento do reator RAS (Etapa 1) e os reatores em batelada (Etapa 2), utilizados no tratamento estatístico. 


\subsubsection{Etapa 1: Operação contínua do reator RAS}

Nas Figuras 5.45, 5.46 e 5.47 são apresentados os diagramas obtidos para a carga orgânica volumétrica global $\left(\mathrm{COV}_{\text {global }}\right)$ aplicada versus a eficiência de remoção de DQO, ao longo do período da operação do reator RAS nas Fases I, II III, respectivamente.

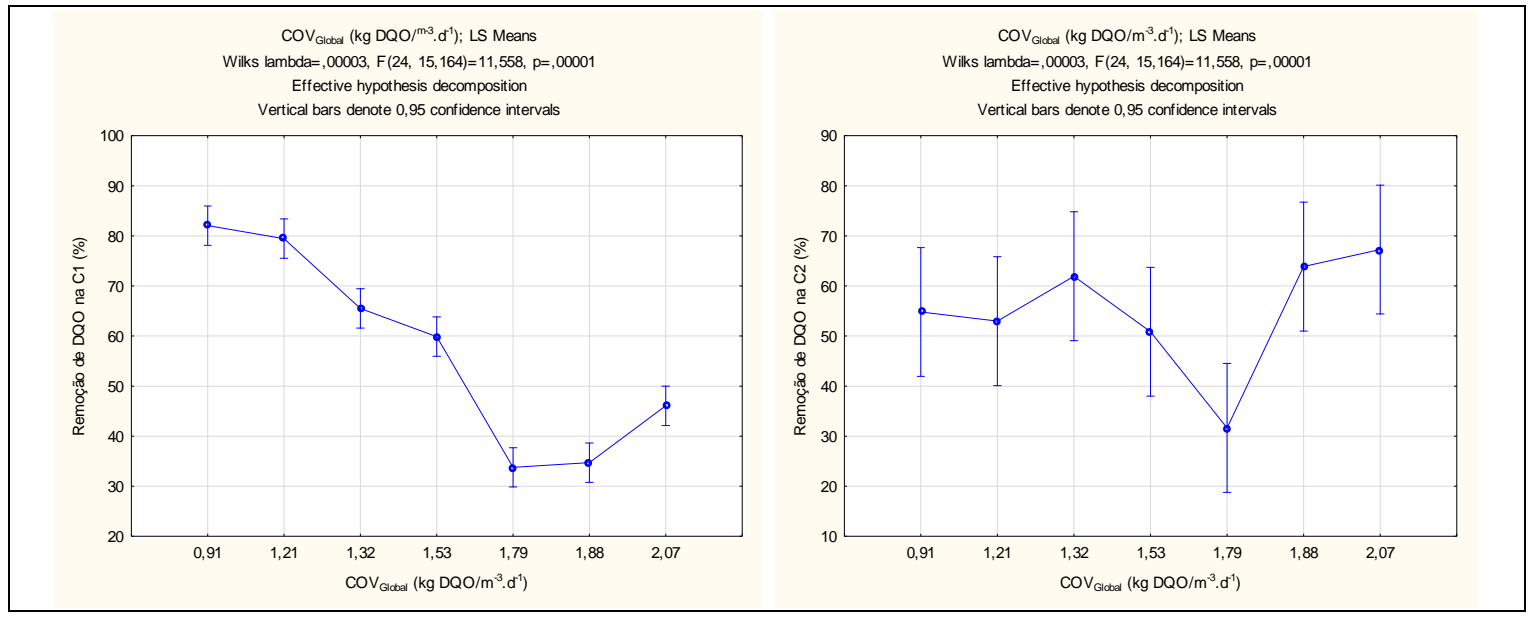

(a)

(b)

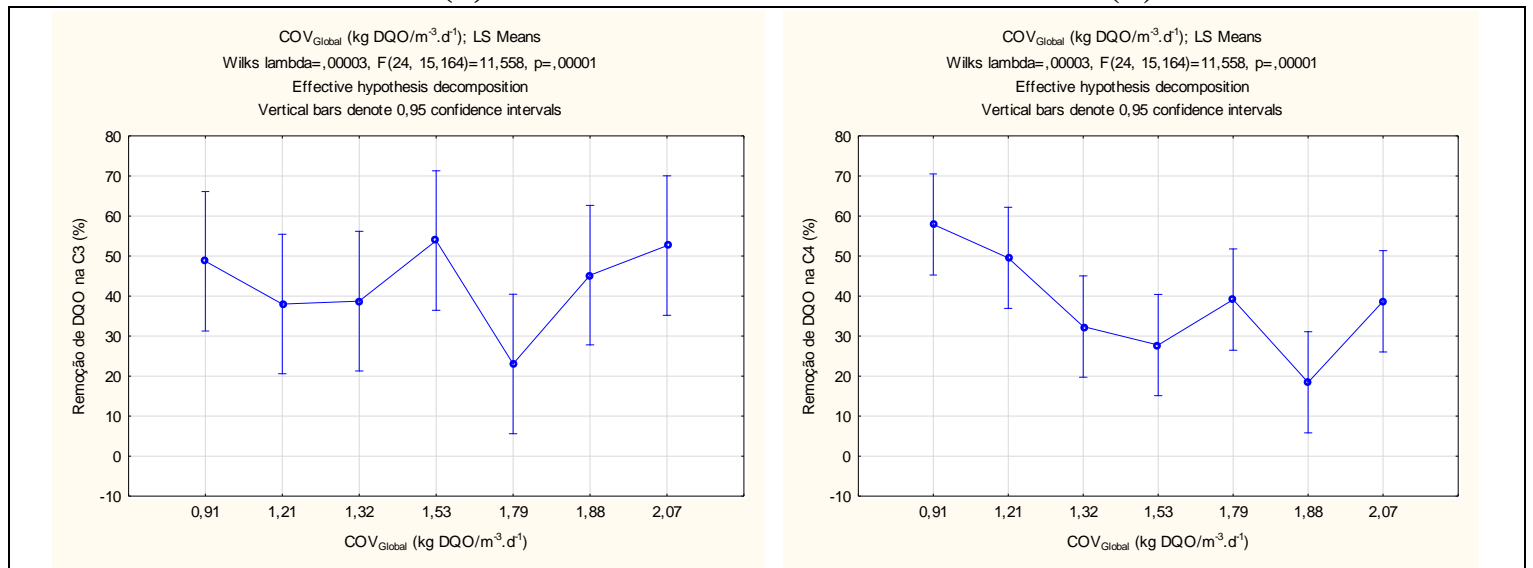

(c)

(d)

Figura 5.45 - COV global versus eficiência de remoção de DQO obtido na operação do reator RAS na Fase I. C1(a), C2 (b), C3(c) e C4 (d). p-valor = 0,000006 

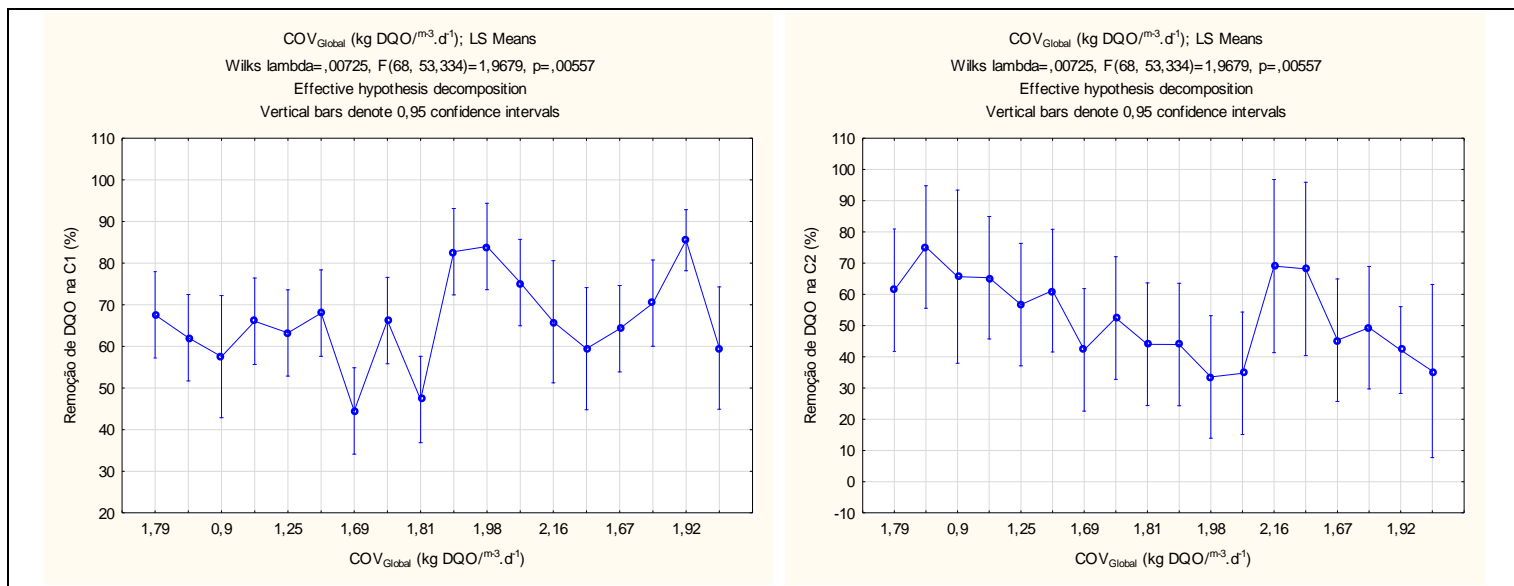

(a)

(b)
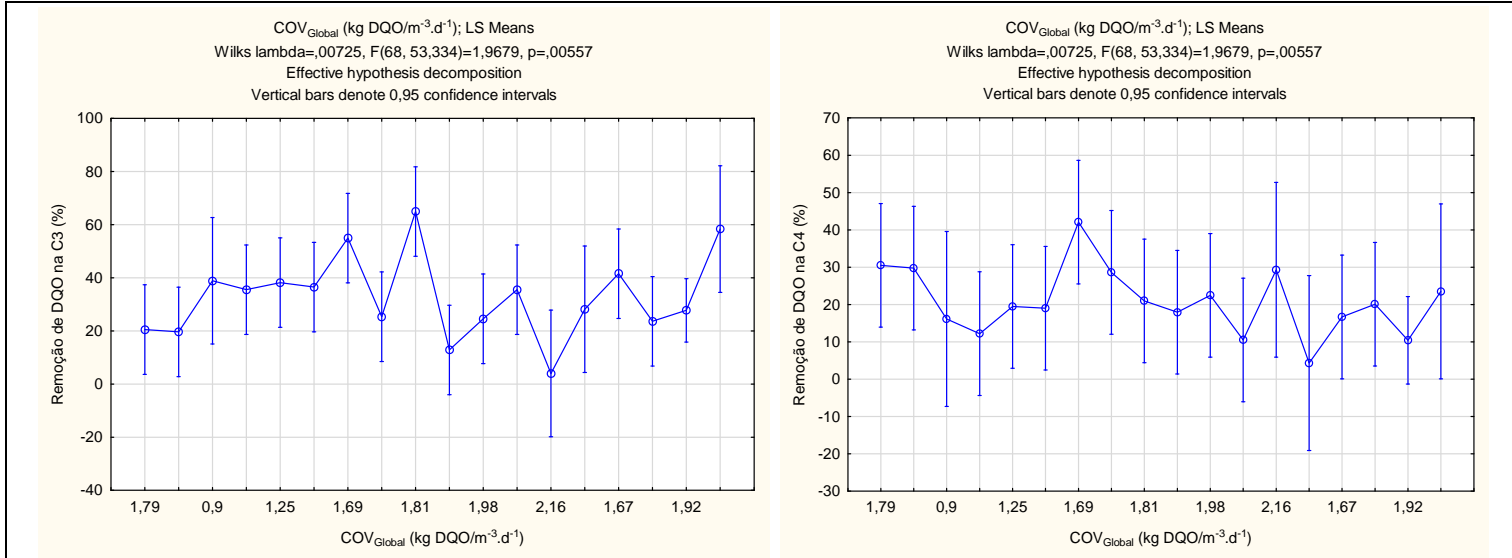

(c)

(d)

Figura 5.46 - $\mathrm{COV}_{\text {global }}$ versus eficiência de remoção de DQO obtido na operação do reator RAS na Fase II. C1(a), C2 (b), C3(c) e C4 (d). $p$-valor $=0,005573$ 


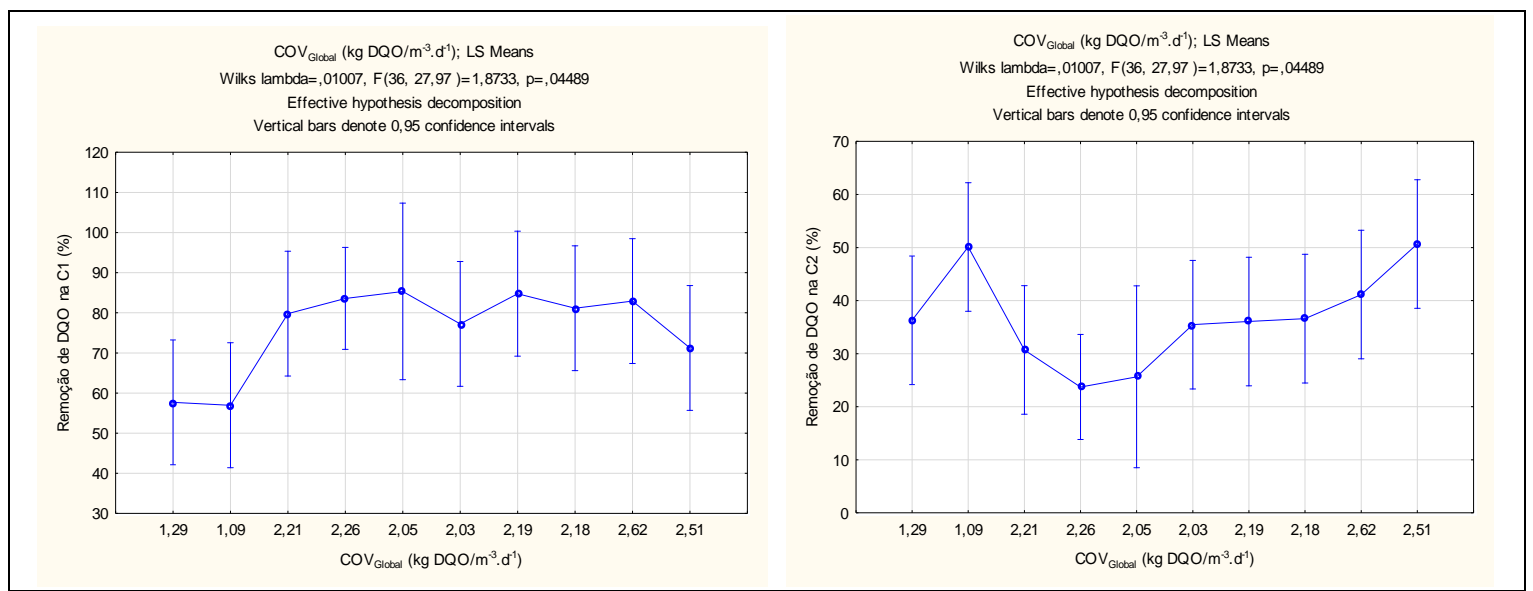

(a)

(b)

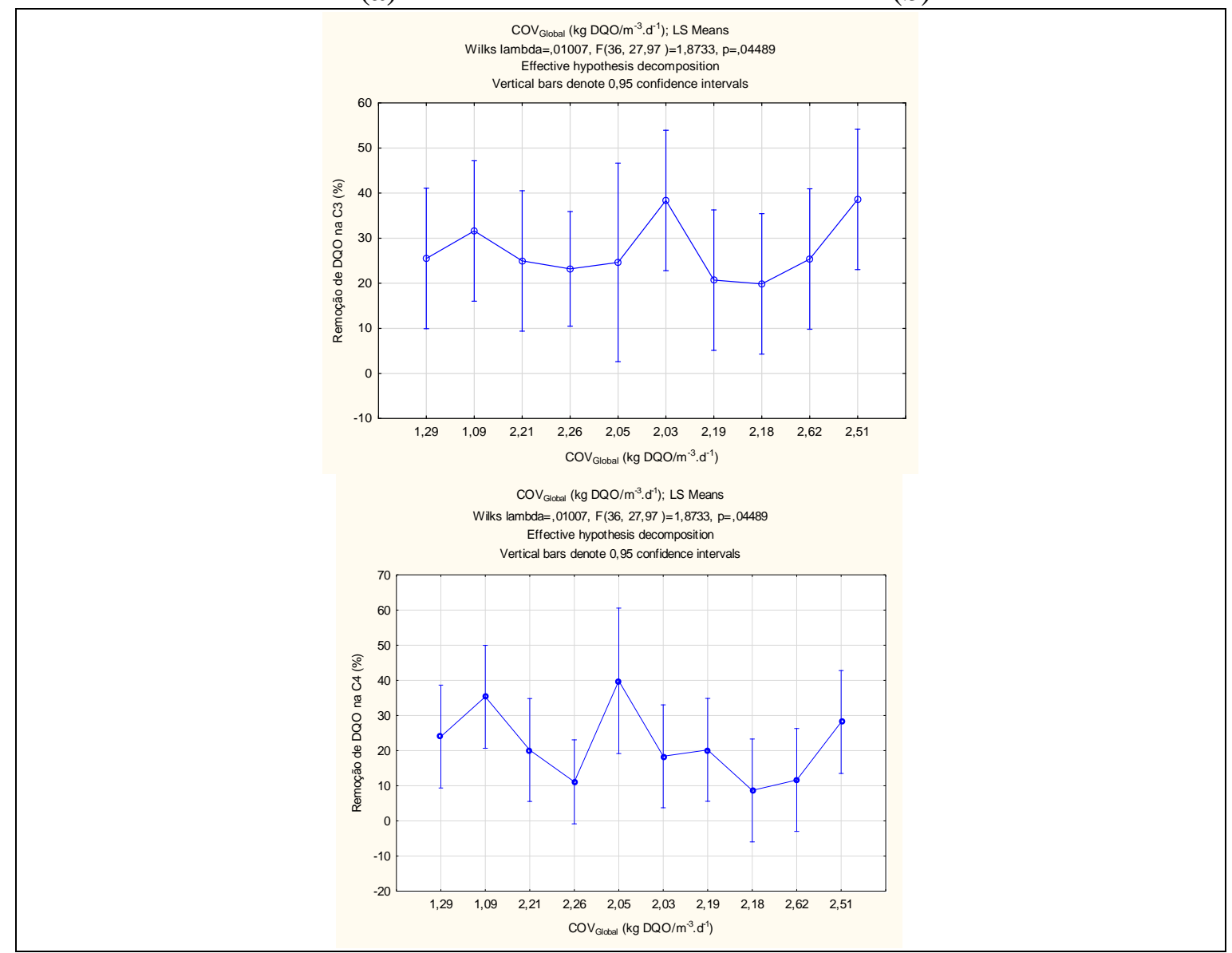

(c)

(d)

Figura 5.47 - $\mathrm{COV}_{\text {global }}$ versus eficiência de remoção de DQO obtido na operação do reator RAS na Fase III. C1(a), C2 (b), C3 (c) e C4 (d). p-valor = 0,044886

Obteve-se ao longo da operação do reator RAS na Fase I, variações de carga orgânica global aplicada $\left(\mathrm{COV}_{\text {global }}\right)$ da ordem de 0,91 a 2,07 $\mathrm{kg} \mathrm{DQO} / \mathrm{m}^{-3} \cdot \mathrm{d}^{-1}$. A análise de variância realizada (Figura 5.45) demonstrou que, há significância estatística na 
influência da $\mathrm{COV}_{\text {global }}$ sobre a remoção de matéria orgânica na forma de DQO para as câmaras C1, C2, C3 e C4, obtendo-se p-valor=0,000006, rejeitando-se portanto a hipótese nula $\left(\mathrm{H}_{0}\right)$.

Para a Fase II conseguiu-se valores de $\operatorname{COV}_{\text {global }}$ aplicadas da ordem de 0,91 a 2,16 $\mathrm{kg} \mathrm{DQO} / \mathrm{m}^{-3} \cdot \mathrm{d}^{-1}$,verificando-se oscilações nos valores obtidos possivelmente decorrentes de instabilidades operacionais já discutidas anteriormente. Para esta fase, observou-se por meio de teste ANOVA (Figura 5.46) que, a $\mathrm{COV}_{\text {global }}$ aplicada influenciou significativamente na remoção de DQO para ambas as câmaras do reator, obtendo-se $p$-valor de 0,005573 .

Em relação a Fase III observa-se a partir da Figura 5.47 que a $\mathrm{COV}_{\text {global }}$ também foi significativa estatisticamente na remoção de DQO, porém, obtendo-se $p$-valor maior $(0,044886)$ quando comparado as Fases I e II, demonstrado certa estabilidade do reator ao final da operação, propiciada certamente pelos ajustes operacionais realizados. Este fato pode ser também observado, pelos maiores valores de carga orgânica global obtidos, da ordem de 1,09 a $2,62 \mathrm{~kg}$ DQO $/ \mathrm{m}^{-3} \cdot \mathrm{d}^{-1}$.

As Figuras 5.48, 5.49 e 5.50 apresentam os diagramas obtidos para a carga orgânica volumétrica global $\left(\mathrm{COV}_{\text {global }}\right)$ aplicada versus a produção de metano, ao longo do período da operação do reator RAS nas Fases I, II III, respectivamente. 


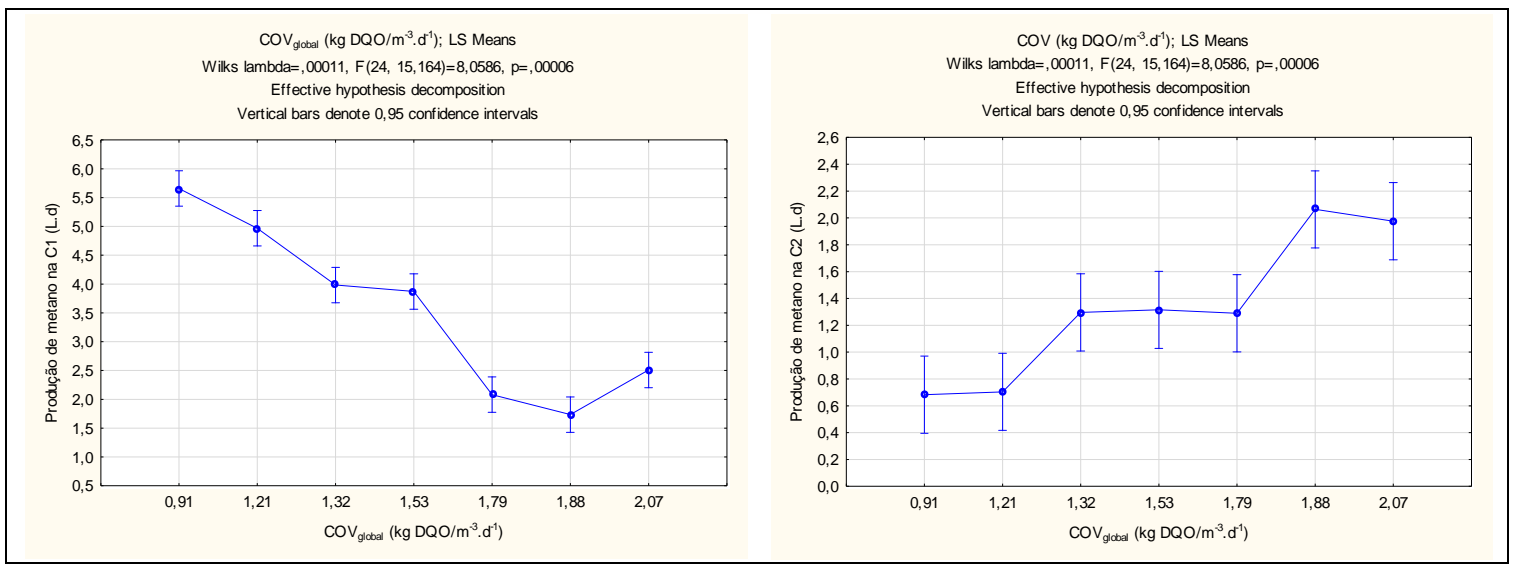

(a)

(b)

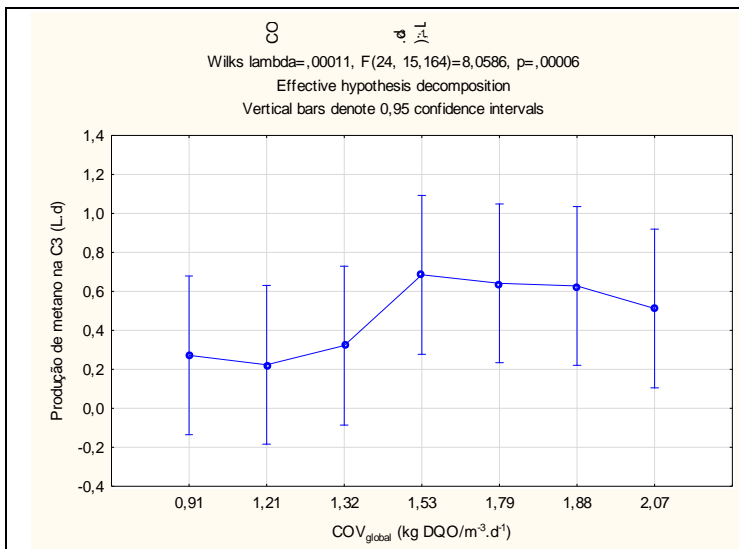

(c)

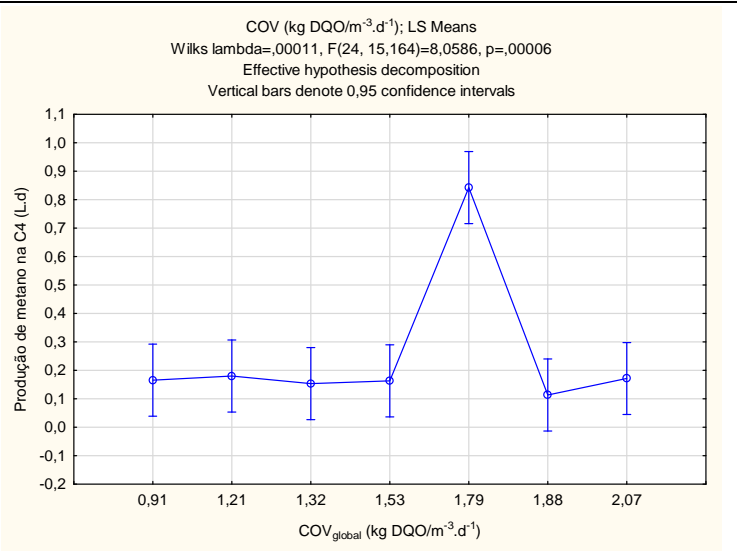

(d)

Figura 5.48 - $\mathrm{COV}_{\text {global }}$ versus produção de metano obtido na operação do reator RAS na Fase I. C1(a), C2 (b), C3 (c) e C4 (d). p-valor = 0,000060. 




(a)

(b)
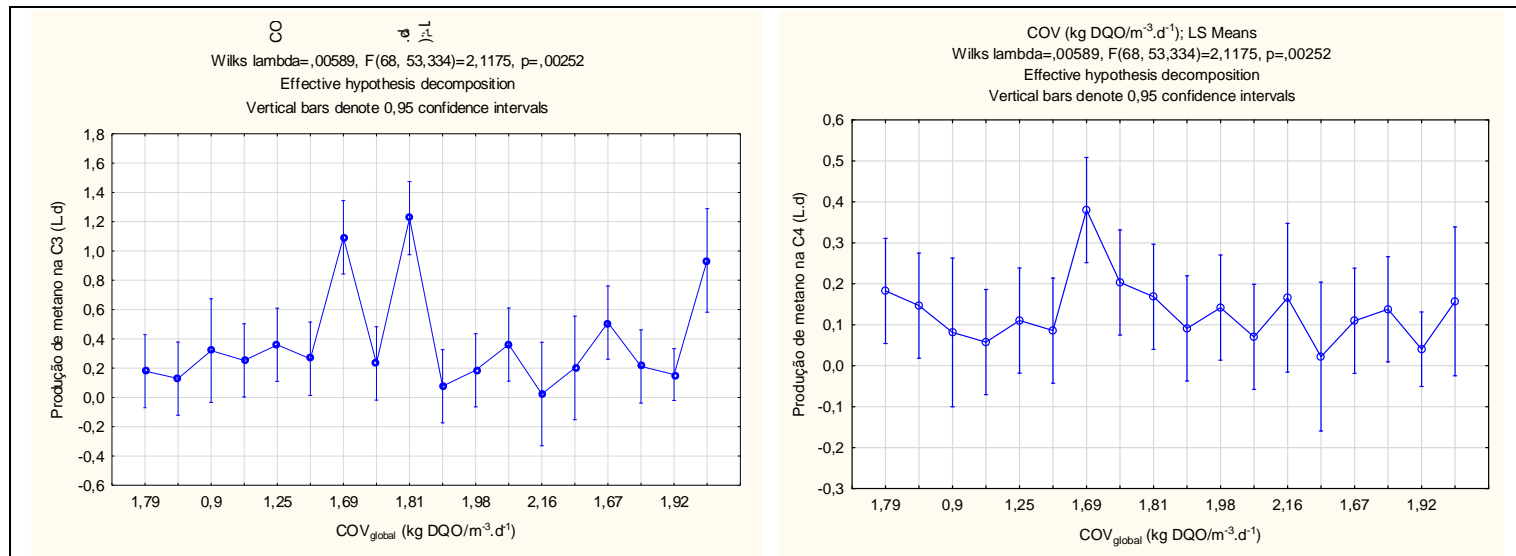

(c)

(d)

Figura 5.49 - $\mathrm{COV}_{\text {global }}$ versus produção de metano obtido na operação do reator RAS na Fase II. C1(a), C2 (b), C3 (c) e C4 (d). $p$-valor $=0,002520$. 


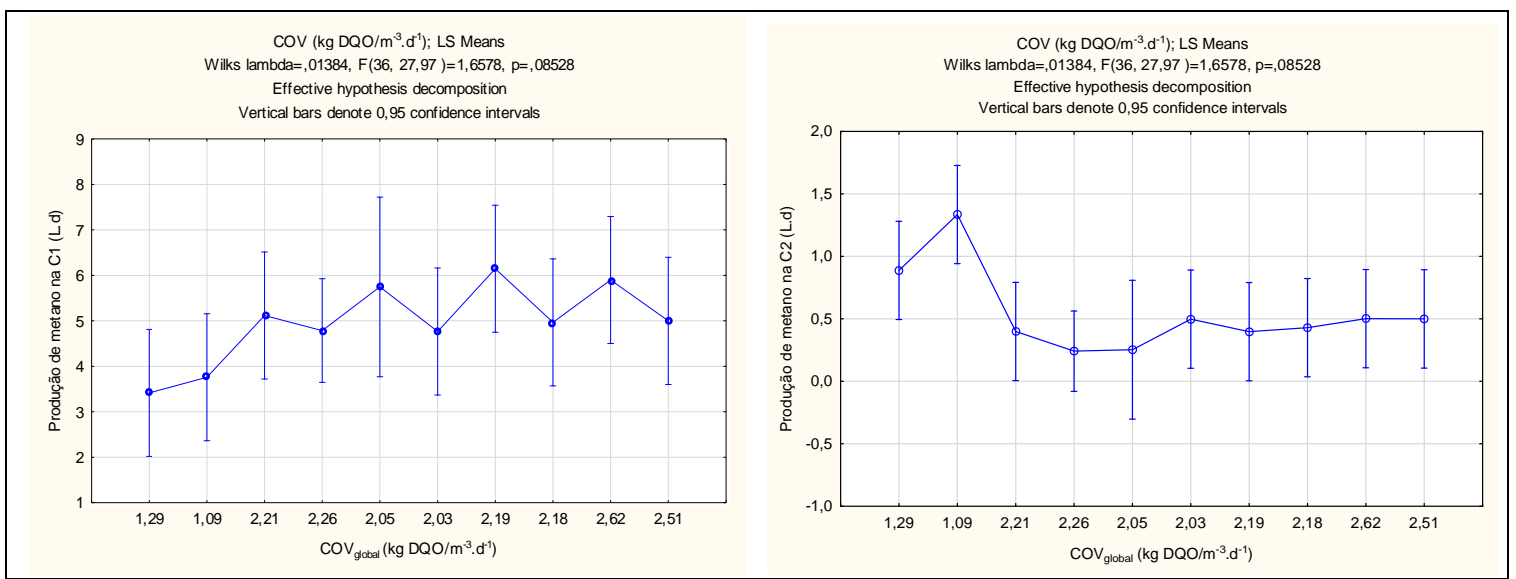

(a)

(b)

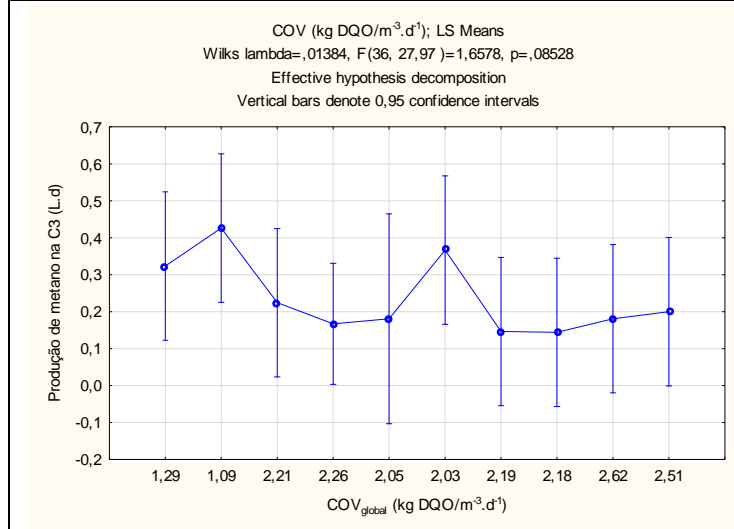

(c)

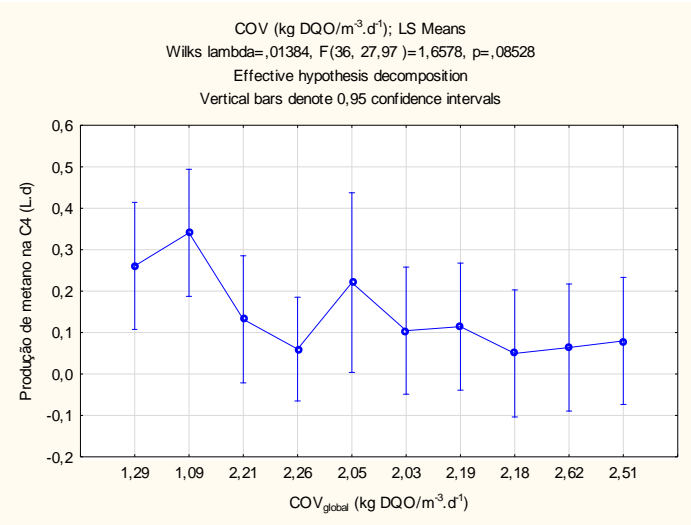

(d)

Figura 5.50 - $\mathrm{COV}_{\text {global }}$ versus produção de metano obtido na operação do reator RAS na Fase III. C1(a), C2 (b), C3 (c) e C4 (d). $p$-valor $=0,085282$.

Assim como observado para a remoção de DQO, os valores de $\operatorname{COV}_{\text {global }}$ aplicadas foi estatisticamente significativo na produção volumétrica de metano para as câmaras do reator RAS, observando-se distintos comportamentos para as câmaras C1,

\section{$\mathrm{C} 2, \mathrm{C} 3$ e $\mathrm{C} 4$.}

Em relação aos $p$-valores obtidos no teste ANOVA este foi significativo para as Fases I ( $p$-valor $=0,000060)$ e II ( $p$-valor $=0,002520)$, corroborando com os resultados do teste para a variável remoção de DQO, e portanto, rejeitando a hipótese de nulidade.

Já para a Fase III (Figura 5.50), considera-se por meio do teste ANOVA que, não houve diferença estatística significativa entre as médias de produção de metano obtidas 
das câmaras C1, C2, C3 e C4, admitindo-se a hipótese de nulidade como sendo verdadeira. O p-valor obtido para esta fase da operação do reator foi de 0,085282.

Visando-se avaliar se a carga orgânica volumétrica individual ( $\left.\mathrm{COV}_{\text {individual }}\right)$ aplicada em cada câmara do reator foi estatisticamente significativa na remoção de DQO e na produção de metano, foram também realizados testes de ANOVA para cada fase individualizada da operação do reator, conforme apresentado na Tabela 5.2.

Tabela 5.2 - Valor- $p$ obtidos para as câmaras do reator RAC nos testes de ANOVA.

\begin{tabular}{ccccc}
\hline \multicolumn{5}{c}{$\mathbf{C O V}_{\text {individual }} \mathbf{x}$ Remoçãa de DQO } \\
\hline Fase I & 0,000006 & 0,030289 & 0,175294 & 0,015678 \\
\hline Fase II & 0,113362 & 0,146303 & 0,955922 & 0,169257 \\
\hline Fase III & 0,118400 & 0,137039 & 0,632167 & 0,665426 \\
\hline & $\mathbf{C O V}$ & $\mathbf{C 2}$ & $\mathbf{C}$ (individual \\
\hline & $\mathbf{C 1}$ & $\mathbf{C 2}$ & $\mathbf{C 3}$ & $\mathbf{C 4}$ \\
\hline Fase I & 0,000010 & 0,004500 & 0,380651 & 0,000264 \\
\hline Fase II & 0,017232 & 0,007562 & 0,976994 & 0,032481 \\
\hline Fase III & 0,220480 & 0,038262 & 0,321865 & 0,283380 \\
\hline
\end{tabular}

Diferentemente como observado para o teste ANOVA utilizando-se a $\mathrm{COV}_{\text {global }}$ como variável independente, no teste estatístico empregando-se a $\mathrm{COV}_{\text {individual }}$ como tal variável, observou-se uma maior variação nos níveis de significância nos parâmetros de remoção de DQO e produção de metano, conforme $p$-valores apresentados na Tabela 5.2.

Para a variável remoção de DQO, os valores de $\mathrm{COV}_{\text {individual }}$ aplicados ao longo da operação do reator RAC na Etapa 1, exerceu influência significativa apenas para as câmaras C1, C2 e C4 na Fase I, evidenciando a rejeição da hipótese nula. 
Em termos da produção volumétrica de metano, observa-se pela análise dos valores- $p$ que a hipótese alternativa $\left(\mathrm{H}_{\mathrm{A}}\right)$ é verdadeira para $\mathrm{C} 1, \mathrm{C} 2$ e $\mathrm{C} 4$ nas Fases I e II, respectivamente, e para C2 na Fase III. Logo, existem diferenças significativas com intervalo de erro menor que $5 \%$, de que a $\mathrm{COV}_{\text {individual }}$ aplicada exerceu influência nos valores médios de produção de metano obtidos pelas câmaras supracitadas.

A câmara C3 apresentou valores- $p$ maiores que 0,05 para ambas as fases de operação do reator (Tabela 5.2), assumindo margens de confiança da ordem de $38 \%$, $97 \%$ e $32 \%$ de probabilidade de a produção de metano neste compartimento estar associado a outros fatores não estudados, e não necessariamente à variável carga orgânica aplicada. Tal fato também pode ser constatado para $\mathrm{C} 1$ e $\mathrm{C} 4$ na última fase da operação do reator RAS (Fase III), com p-valor de 0,220480 e 0,283380, respectivamente.

\subsubsection{Etapa 2: Operação dos reatores ASBR em batelada}

Nas Figuras 5.51 e 5.52 são apresentados os diagramas de dispersão obtidos para as variáveis carga orgânica aplicada ao lodo (COAL) e eficiência de remoção de DQO, COAL e produção de metano, respectivamente, ao longo das fases dos ensaios em batelada.

Da mesma forma, na Tabela 5.3 são apresentados os valores- $p$ obtidos do teste de variância para os reatores anaeróbios operados em batelada sequencial. 


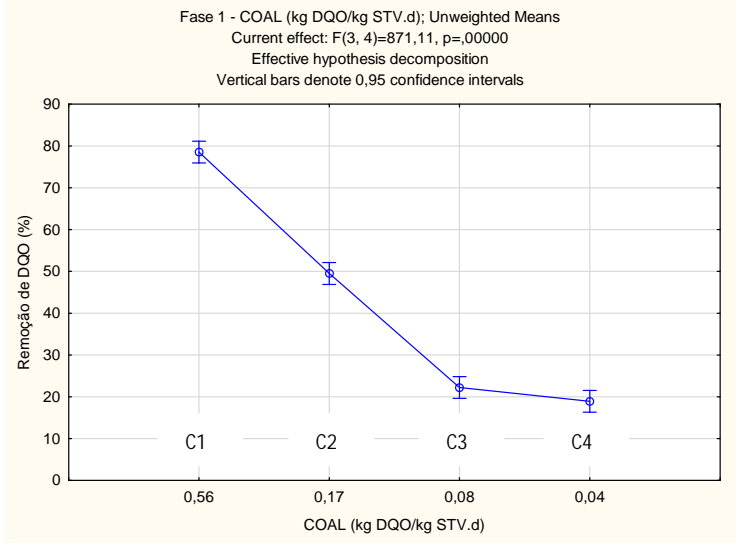

(a)

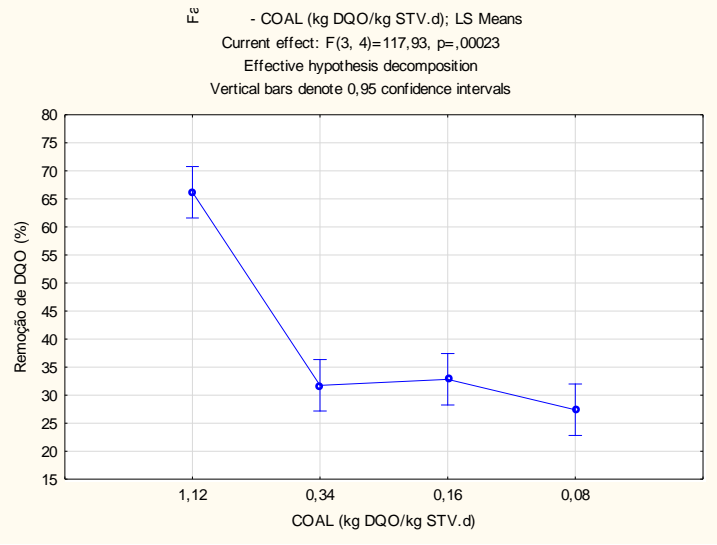

(b)

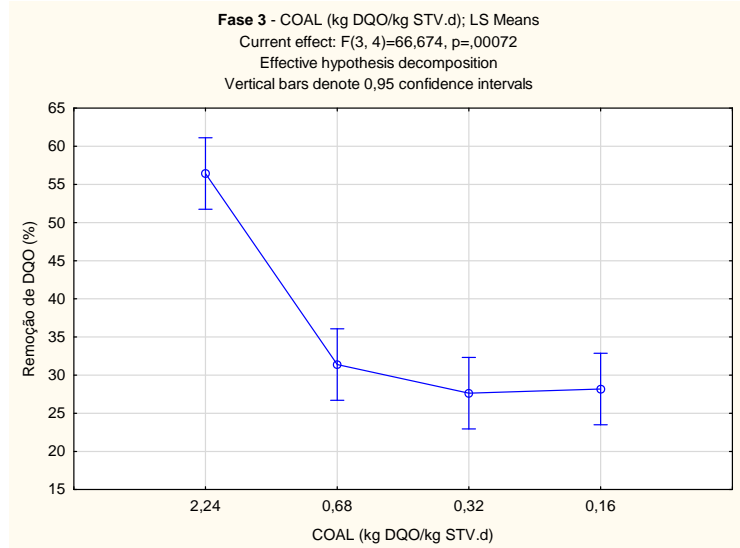

(c)

Figura 5.51 - COAL versus remoção de DQO nos ensaios em batelada. Fase 1 (a), Fase 2 (b) e Fase 3 (c). 


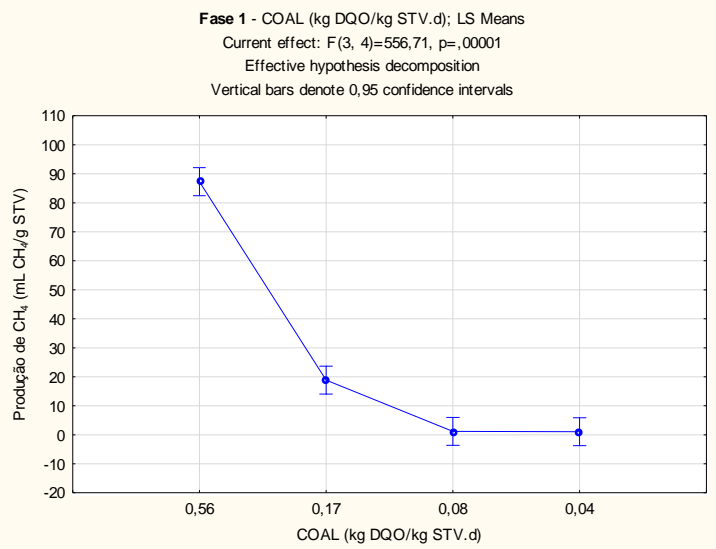

(a)

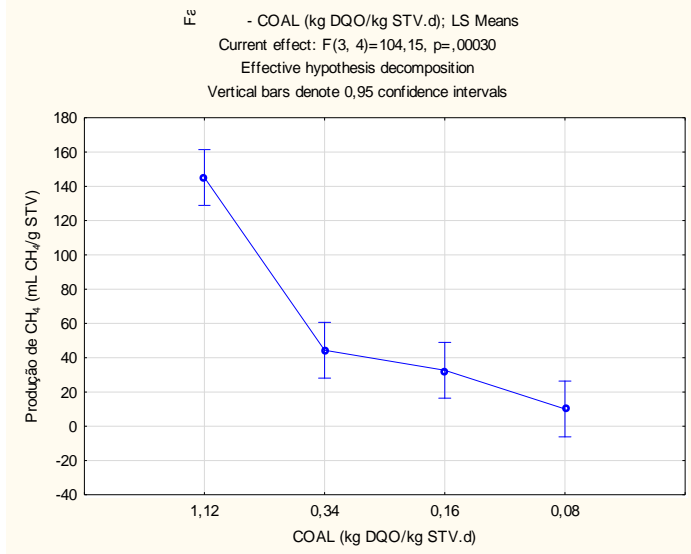

(b)

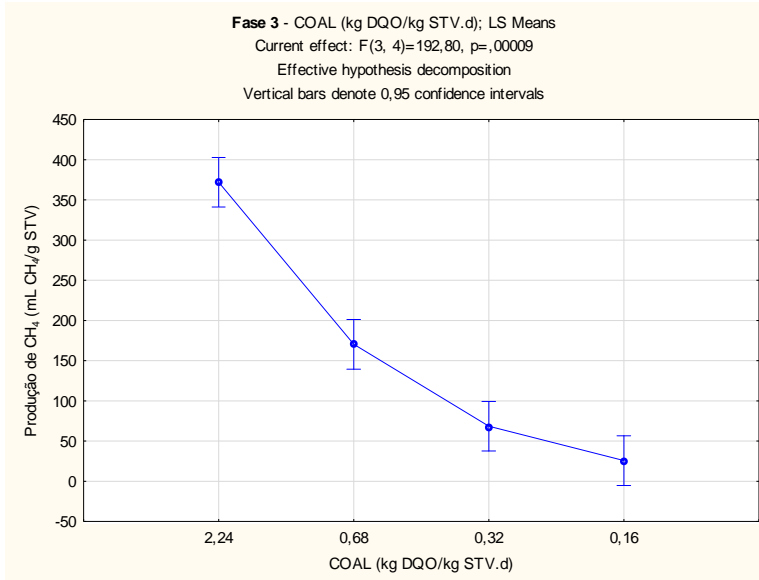

(c)

Figura 5.52 - COAL versus produção de metano nos ensaios em batelada. Fase 1 (a), Fase 2 (b) e Fase 3 (c).

Tabela 5.3 - Valores- $p$ obtidos para os reatores operados em batelada sequencial nos testes ANOVA.

\begin{tabular}{l|c}
\hline \multicolumn{2}{c}{ COAL x Remoção de DQO } \\
\hline Fase I & 0,000004 \\
\hline Fase II & 0,000233 \\
\hline Fase III & 0,000716 \\
\hline COAL x Produção de Metano \\
\hline Fase I & 0,000011 \\
\hline Fase II & 0,000298 \\
\hline Fase III & 0,000088 \\
\hline
\end{tabular}


Analisando as Figuras 5.51 e 5.52 observa-se que, em ambas as fases e para ambos os parâmetros, o teste ANOVA revelou diferenças significativas entre as médias dos valores analisados para ambos os reatores, por tanto, rejeitando a hipótese $\mathrm{H}_{0}$.

Notadamente, assim como observado na operação contínua do reator RAS, os maiores valores de COAL aplicados em $\mathrm{C} 1$ e $\mathrm{C} 2$, proporcionaram as maiores eficiências de remoção de matéria orgânica e produção volumétrica de metano.

A partir dos valores- $p$ obtidos dos ensaios do processamento de vinhaça pelo teste de análise de variância (Tabela 6.2), verifica-se que as condições operacionais impostas nas Fases I, II e III foram estatisticamente significativas para as variáveis estudadas (remoção de DQO e produção de metano), obtendo-se intervalos de confiança acima de $95 \%$. 


\section{Conclusões}

Com base nos resultados obtidos do presente trabalho, referentes a primeira e segunda etapas, bem como do tratamento estatístico, pode-se concluir que:

\section{Etapa 1 - Operação do reator RAS em sistema contínuo}

. O reator anaeróbio serial processando vinhaça de cana-de-açúcar operou sob baixos valores de carregamento orgânico global aplicado, obtendo-se máxima de 2,50 $\mathrm{kg} \mathrm{DQO} / \mathrm{m}^{3} \cdot \mathrm{d}^{1}$. No entanto, considerando as cargas orgânicas individuais aplicadas, valores maiores foram obtidos, da ordem de $10,5 \mathrm{~kg} \mathrm{DQO} / \mathrm{m}^{3} \cdot \mathrm{d}^{1}$ para $\mathrm{C} 1$ (Fase III).

, Maior carga orgânica foi removida no reator C1 em consequência aos baixos valores de $\mathrm{COV}_{\text {individual }}$ e $\mathrm{COAL}_{\text {individual }}$ aplicadas aos reatores subsequentes.

Com base nos resultados obtidos espera-se que reatores semelhantes possam atingir eficiências entre 90 a $95 \%$ na remoção de matéria orgânica forma de DQO.

. O tamponamento da vinhaça foi fundamental para o seu processamento, tendo em vista a adequação do $\mathrm{pH}$ (entre 6,6 e 7,7) e a posterior neutralização dos ácidos voláteis produzidos. 
Em relação à composição do biogás produzido, para todas as fases da operação (I, II e III), verificou-se que o metano é o gás predominante no biogás, com percentagem acima de $80 \%$ (C1), que confirmam o estabelecimento do sistema metanogênico.

A biomassa proveniente da câmara $\mathrm{C} 1$ apresentou maior atividade metanogênica quando comparada as câmaras subsequentes.

Foram observadas, por meio das imagens de microscopia de contraste de fase e MEV, variações da densidade e diversidade morfológica para os microrganismos metanogênicos (predomínio de Methanosaeta sp) presentes nas diferentes câmaras, decorrentes das condições operacionais encontradas em cada compartimento em termos de fornecimento de substrato orgânico afluente.

. Na análise do domínio e índice de diversidade de Shannon observa-se a especialização das populações microbianas pertencentes aos domínios Archaea e Bacteria ao longo das câmaras do reator serial.

. Verificou-se, por meio do sequenciamento filogenético a predominância e manutenção de microrganismos do filo Euryarchaeota e do gênero Methanosaeta para o domínio Archaea em todas as câmaras do reator RAS.

, Em relação a caracterização filogenética do domínio Bacteria, verificouse a predominância de microrganismos anaeróbios e sacarolíticos (gênero T78), corroborando o elevado consumo de carboidratos verificado nos reatores. 
As instabilidades operacionais verificadas ao longo da operação dos reatores ao final das Fases I e II, bem como o aumento de carregamento orgânico aplicado, não ocasionaram a inibição e redução da abundância relativa dos grupos de arqueias metanogênicas quando comparado ao lodo de inóculo utilizado.

, De modo geral, os resultados obtidos da primeira etapa do trabalho indicam a potencialidade do processamento da vinhaça de cana-de-açúcar em reatores sequenciais (RAS) para a redução da carga orgânica poluente, visando o seu potencial aproveitamento energético por meio da produção de biogás com elevado teor de metano e, posterior emprego da vinhaça processada na fertirrigação de solos.

\section{Etapa 2 - Operação dos reatores ASBR em batelada sequencial}

, O aumento da COAL estipuladas nas Fases II e III, permitiu a obtenção de valores de carga orgânica mais elevadas do que as observadas na operação contínua do reator RAS na Etapa 1.

, O aumento da taxa de carregamento orgânico aplicado ao lodo imposta aos reatores nos ensaios em batelada sequencial nas Fases II e III, não ocasiona a inibição da degradação anaeróbia da vinhaça nas condições investigadas.

. Nos ensaios dos reatores em batelada foram obtidas remoções global de matéria orgânica em termos de DQO entre $83 \%$ a 93\%, corroborando com o bom desempenho do reator RAS na Etapa 1. 
A remoção de carboidratos foi efetiva para as fases dos ensaios em batelada, obtendo-se valores percentuais de remoção global superiores a $94 \%$.

, Houve geração e acúmulo de ácidos orgânicos em todas as fases de operação dos reatores em batelada, com o aumento do carregamento orgânico aplicado. Constata-se que o excesso de ácidos orgânicos produzidos inicialmente em C1 e não prontamente consumidos pela biomassa microbiana, são acumulados e posteriormente encaminhados para os reatores subsequentes, principalmente o ácido acético.

- A produção de metano é significativa na operação dos reatores em batelada, principalmente em $\mathrm{C} 1$.

- A composição de metano observada foi elevada para todos os reatores e fases dos ensaios, sendo que, o aumento dos valores de COAL aplicados nas Fases II e III, favoreceu a maior concentração de metano presente no biogás produzido.

. A estrutura da comunidade de arqueias apresentou pouca variação entre os reatores em batelada, com o aumento dos valores de COAL de 0,04 a 2,24 kg DQO/kg STV.d.

. A diversidade bacteriana apresentou distintos comportamentos frente às taxas de carregamento orgânico aplicada ao lodo, decorrente da especialização desses organismos às condições operacionais impostas aos reatores em batelada. 


\section{Análise estatística}

, O teste de ANOVA revelou que há significância estatística entre a $\mathrm{COV}_{\text {global }}$ e $\mathrm{COAL}_{\text {global }}$ aplicadas na remoção de DQO e produção volumétrica de metano, com valores de significância acima de $95 \%$. 


\section{Sugestões Para Trabalhos Futuros}

Para trabalhos futuros, sugere-se:

Determinar a real produção de biogás pelo reator RAS;

Avaliar a bioquímica dos ácidos orgânicos produzidos ao longo das câmaras do reator RAS;

- Estudar a cinética da remoção de matéria orgânica pelo reator RAS; e

- Estudar modificações na concepção e configuração estrutural do reator serial em escala aumentada. 


\section{Referencias Biblograficas}

AISSE, M. M.; LOBATO, M. B.; BONA, A.; GARBOSSA, L. H. P. (2000). Estudo comparativo do reator UASB e do reator anaeróbio compartimentado sequencial no tratamento de esgoto sanitário. In: Congresso Interamericano de Engenharia Sanitária e Ambiental, 27., 2000, Fortaleza.

AISSE, M.A.; ALÉM SOBRINHO, P. Avaliação do sistema reator UASB e filtro biológico aerado submerso para o tratamento de esgoto sanitário. (2001). Póstratamento de Efluentes de Reatores Anaeróbios. Coletânea de Trabalhos Técnicos. PROSAB 2, V2. Belo Horizonte: Segrac Editora e gráfica Ltda, p. 111-118.

ABREU, E.F. Estudo da diversidade microbiana metanogênica em reatores UASB tratando esgoto sanitário. Dissertação (Mestrado), Departamento de Engenharia Sanitária e Ambiental, UFMG, Belo Horizonte, 2007, 93p.

AQUINO, S.F. et al. Metodologias para determinação da atividade metanogênicaespecifíca (AME) em lodos anaeróbios. Engenharia Sanitária e Ambiental. v.12, n.2, p.192-201, abr/jun, 2007.

AMANN, R.; LUDWIG, W.; SCHLEIFER, K.H. (1995). Plylogenetic identification and in situ detection of individual microbial cells without cultivation.Microbiological Reviews, v.59, n.1, p.143-169.

APHA, Standard Methods for the Examination of Water and Wastewater.21 $1^{\mathrm{a}}$ ed., American Public Health Association, Washington, D.C., USA, 2005.

ARIESYADY, H.D., ITO, T., OKABE, S. Functional bacterial and archaealcommunity structures of major trophic groups in a full-scale anaerobic sludgedigester. Water Res. 41 (7), 1554-1568, 2007.

BACHMANN, A.; BEARD, V.L.; McCARTY, P.L. (1985).Performance characteristics of the anaerobic baffled reactor.Water Research, New York, v. 19, n.1, p.99-106. 
BARBER, W.P.; STUCKEY, D.C. (1999). The used of an anaerobic baffled reactor (ABR) for wastewater treatment: A Review. WaterResearch. 33 (Orozco, 1997) 1559 .

BARROS, A.R.; REIS, C.M.; SILVA, E.L. Aplicação da vinhaça para produção de hidrogênio em reator anaeróbio de leito fluidificado. In: Anais do I Seminário Temático, Universidade de São Paulo, São Carlos, 2011.

BERMÚDEZ- SAVÓN,R.C.; HOYOS- HERNÁNDEZ J.A.; RODRÍGUEZ- PÉREZ S. (2000). Evaluacion de ladisminución de la carga contaminante de lavinaza de destilería por tratamento anaeróbio. Rev. Int. Contam. Ambient. 16 (3), p.103- 107.

BOOPATHY, R.; TILCHE, A. (1991).Anaerobic Digestion of High Strength Molasses Wastewater Using Hybrid Anaerobic Baffled Reactor.Water Research, v. 25, n. 7, p. 785-790.

BOOPATHY, R. (1998). Biological treatment of swine waste using anaerobic baffled reactors. Bioresource Technology. v. 64, Issue 1, April, p.1-6.

BORGES, E. S. M. Tratamento térmico de lodo anaeróbio a partir da queima do biogás produzido em reator UASB objetivando a higienização e a melhoria da biodisponibilidade e biodegradabilidade da fração orgânica. Tese de doutorado em Saneamento, Meio Ambiente e Recursos Hídricos, UFMG, 2004.

BRENNER, D.J.; KRIEG, N.R.; STALEY, J.T. Bergey's Manual of Systematic Bacteriology. 2nd New York: Ed. Springer. 2005.

BROWN, A. Y.T. et al. Influência do carregamento orgânico, hidráulico e recirculação sobre o desempenho de reator UASB empregado no tratamento da vinhaça. X Latin American Workshop and Symposium on Anaerobic Digestion, OuroPreto, 2011.

Cabezas, A.; Araujo, J.C.; Callejas, C.; Galès, A., et al. (2015). How to use molecular biology tools for the study of the anaerobic digestion process? Reviews in Environmental Science and Bio/Technology, v. 14.

CABEllo, P.E.; SCOGNAMiGliO, F.P.; TERÁN, F.J.C. (2009).Tratamento de vinhaça em reator anaeróbio de leito fluidificado. Engenharia Ambiental (online), Espirito Santo do Pinhal, jan/abr. v6, n.1, p.321-338. 
CAMMAROTA, M. C. Notas de aula da disciplina Tratamento de Efluentes Líquidos. EQB-482 Engenharia do Meio ambiente- Escola de química/UFRJ, 2010.

CAMPOS, J. R. Tratamento de esgotos sanitários por processo anaeróbio e disposição controlada no solo. José Roberto Campos (coordenador). -- Rio de Janeiro: ABES, 1999. 464p.

CORTEZ, L.A.B., FREIRE, W.J., ROSILLO-CALLE, F., Biodigestion of vinasse in Brazil, Internacional Sugar Journal, Vol.100, nº 1196, 1996.

COUTINHO, H. L. da C.; OLIVEIRA., V. M. de; MANFIO, G. P.; ROSADO, A. S. Evaluating the microbial diversity of soil samples: methodological innovations. Anaisda Academia Brasileira de Ciências, Rio de Janeiro, v. 71, n. 3, p. 491-503, 1999.

CHERNICHARO, C. A. L., et al. Desenvolvimento de um respirômetro automatizado para avaliação da atividade microbiana anaeróbia. Revista de Engenharia Sanitária, v. 2, n. 3-4,p. 120-126, 1997.

CHERNICHARO, C.A. de L. Princípios do tratamento biológico de águas residuárias: Reatores Anaeróbios. 2.ed. Belo Horizonte: Departamento de engenharia Sanitária e Ambiental, 2007.

CRUZ, J. I. da; HOJDA, A.; PORTUGAL, R. de S. Atuação do comitê da bacia hidrográfica do rio pardo na problemática da contaminação de águas subterrâneas pela vinhaça: carência de informações e ações. In: $24^{\circ}$ Congresso Brasileiro de Engenharia Sanitária e Ambiental. Belo Horizonte, 2007.

DAMIANIVIC, M.H.R.Z. Degredação de pentaclorofenol (PCP) em reatores anaeróbios horizontais de leito fixo (RAHLF). Dissertação (Mestrado), Escola de Engenharia de São Carlos, USP, São Carlos/SP 1997.

DEL NERY, V.; POZZI, E.; DAMIANOVIC, M.H.R.Z.; DOMINGUES, M.R.; ZAIAT, M. (2008). Granules characteristics in the vertical profile of a full-scale upflow anaerobic sludge blanket reactor treating poultry slaughterhouse wastewater. Bioresour.Technol. 99, 2018-2024. 
DILALLO,R.,ALBERTON O.E. Volatile acids by direct titration. Journal of water pollution control federation, v. 33, n.4, p. 356-356. 1961.

DöLL, M.M.R.; FORESTI, E. Efeito do bicarbonato de sódio no tratamento de vinhaça em AnSBBR operado a 55 e $35^{\circ} \mathrm{C}$. Eng. Sanit. Ambient. vol.15 no.3 Rio de Janeiro July/Sept. 2010.

DRIESSEN, W.; YSPEERT, P. (1999).Anaerobic treatment of low, médium and high strength efluente in the agro-industry.Water Science Technology, 40, p.89-96.

FAN. X., GYO, R., YUAN, Z., QIU, Z., YANG, Z., WANG, F., SUN, M., ZHAO, X. Biogas production from Macrocystispyrifera biomass in seawater system. Bioresource Technology 197 (2015) 339-347.

FANG, H.H.P., CHUI, H.K., LI, Y.Y. (1995). Microstructural analysis of UASB granules treating brewery wastewater. Wat. Sci. Tech., 31(9), 129-135.

FERNADEZ, N.et al., (2008). Performance evaluation of na anaerobic fluidized bed reactor with natural zeolite as support material when treating high-strength distillery wastewater. Renewable Energy, 33, p.2458-2466.

FORESTI, E.; FLORÊNCIO, L.; HAANDEL, A. van; ZAIAT, M.; CAVALCANTI, P. F. F. Tratamento de esgotos sanitários por processo anaeróbio e disposição controlada no solo. Rio de Janeiro: ABES, 1999. cap. 2, p. 29-52.

FOXON, K.M.; PILLAY, S.; LALBAHADUR, T.; RODDA, N.; HOLDER, F.; BUCKLEY, C.A. (2004). The anaerobic baffled reactor (ABR) - An appropriate technology for on-site sanitation.. In: Water SA 30, 5.

GOODALL, D. W. (1966). A New Similarity Index Based on Probability. Biometrics, v. 22, n. 4 , p. $882-907$.

GONZALEZ, J.S.; RIVERA, A.; BORJAB, R.; UNCHEZ, E. (1998). Influence of organic volumetric loading rate, nutriente balance and alkalinity: COD ratio on the anaerobic sludge granulation of an UASB reactor treating sugar cane molasses. International Biodeterioration e Biodegradation, 41, 127-131.

GLÓRIA, N. A.; ORLANDO FILHO, J. Aplicação de vinhaça como fertilizante. Boletim Técnico do Planalsucar, Araras, v.5, p.5-38, 1983. 
GRACIANO, W.P. Delineamento das condições biológicas e físico-químicas para a biodigestão de vinhaça. Dissertação (Mestrado), Universidade de Riberão Preto. Riberão Preto, 2007, 80p.

GRANATO, E.F. Geração de energia através da biodigestao anaeróbica da vinhaça. Dissertação (Mestrado), Faculdade de Engenharia da UNESP. Bauru, 2003, 139p.

GRADY JÚNIOR, C.P.L.; LIM, H.C. Biological waste treatment. New York: Marcel Dekker, 1980.

GRIFFITHS, R. I; WITELEY, A. S.; O`DONNELL, A. G.; BAILEY, M. J. (2000).Rapid method for co-extraction of DNA and RNA from natural environments for analysis of ribosomal DNA and rRNA-based microbial community composition.Applied and Environmental Microbiology, v. 66, p. 5488-5491.

GROBICKI, A.; STUCKEY,D.C. (1992). Hidrodynamic characteristics of the Anaerobic Baffled Reactor.Water Research, v.26, n.3, p. 371-378.

GROVER, R.; MARWAHA, S. S.; KENNEDY, J. F. Studies on the use of an anaerobic baffled reactor for the continuous anaerobic digestion of pulp and paper mill black liquors. ProcessBiochemistry, Oxford, v. 34, p. 653-657, 1999.

HIRASAWA, J.S. Avaliação da metanogênese e sulfetonogênese na presença de oxigênio, sob diferentes relações etanol/sulfato, utilizando técnicas de biologia molecular. Tese (Doutorado), Escola de Engenharia de São Carlos, USP. São Carlos, $2007,134 p$.

HOBSON, P. N.; WHEATLEY, A.D. Anaerobic digestion: modern theory and practice. Elsevier Applied Science, 1993. 269p.

HUTNAN, M.; DRTIL , M.; MRAFKOVÁ, L.,; DERCO, J.; BUDAY, J. Comparison of startup and anaerobic wastewater treatment in UASB, hybrid and baffled reactor. Bioprocess Engineering, New York, n. 21, p. 439-445, 1999.

JAMES, A., CHERNICHARO, C. A. L., CAMPOS, C.M.M. 1990. The development of a new methodology for the assessment of specific methanogenic activity. Water Research, v. 24, p. 813-825. 
JIMÉNEZ, A.M.; BORJA, R.; MARTÍN, A. (2003).Aerobic-anaerobic biodegradation of beet molasses alcoholic fermentation wastewater.Processes Biochemistry 36, p.1275-1284.

KANIMOZHI, R.; VASUDEVAN, N.An overview of wastewater treatment in distillery industry.Int. J. Environmental Engineering, Vol. 2, Nos. 1/2/3, 2010.

KATO, M.T.; FLORENCIO, L.; ARANTES, R.F.M. (2001). In: Pós-tratamento de efluentes de reatores anaeróbios. Coletânea de trabalhos técnicos. CHERNICHARO, C.A.L. (coord.). PROSAB, Belo Horizonte, 2, p.165-184.

KUDO, Y.; NAKAJIMA, T.; MIYAKI, T.; OYAIZU, H. (1997).Methanogen flora of paddy soils in Japan. FEMS MicrobiologyEcology, v. 22: p. 39-48.

LAMONICA, H.M. (2006). Potencial de geração de excedentes de energia elétrica a partir da biodigestão da vinhaça, Campinas, 06 jun. 2006. Palestra proferida no AGRENER 2006.

LANGENHOFF, A. A. M.; STUCKEY, D. C. (2000). Treatment of dilute wastewater using an anaerobic baffled reactor: effect of low temperature. Water Research, Oxford, v. 34, n. 15, p. 3867-3875.

LECLERC, M.; DELGÈNES, J.; GODON, J. (2004).Diversity of the Archaea community in 44 anaerobic digesters as determined by single strand conformation polymorphism analysis and 16S rDNA sequencing. Environ Microbiol 6: 809-819.

LETTINGA, G.; VAN VELSON, A.F.M.; HOBMA, S.W.; DE ZEUW, W.; KLAPWIJK, A. (1980).Use of the upflow sludge blanket (UASB) reactor concept for biological wastewater treatment, especially for anaerobic treatment. Biotechnol. Bioeng., 22, p.699-734.

LI, F. NELSON, M. C.; CHEN, PS. GRAF, J., LU, Y., YU, Z. Comparison of the microbial communities in solid-state anaerobic digestion (SS-AD) reactors operated at Mesophilic and thermophilic temperatures. Appl. Microbiol. Biotechnol (2015) 99:969-980 
MACHADO, O.J.; FREIRE, F.B. (2009). Tratamento de vinhaça em reator anaeróbio de fluxo anaeróbio e manta de lodo (UASB). OLAM - Ciência \& Tecnologia, Rio Claro, SP, 2009.

MAHMOUD, N.; ZEEMAN, G.; GIJZEN, H.; LETTINGA, G. (2003).Solids removal in upflow anaerobic reactors, a review.Bioresource Technology, 90: 1-9.

METCALF \& EDDY.Inc. (2003).Wastewater Engineering treatment Disposal Reuse. 4. ed. New York, McGraw - Hill Book, 1815p.

MCCARTY, P.L., 1981. One hundred years of anaerobic treatment digestion 1981. In: Hughes, et al. (Ed.). In: Anaerobic Digestion, vol. 1. Elsevier Biomedical Press, pp. $3-21$.

McCARTY, P. L.; MOSEY, F. E. Modelling of anaerobic digestion processes (a discussion of concepts). Water Science and Technology. v. 24, p.17-33, 1991.

MONTEGGIA, L. O. The Use of Specific Methanogenic Activity for Controlling Anaerobic Reactors. Newcastle: University of Newcastle Upon Tyne. England, 1991, 307f. Tese (Doutorado).

MONTEGGIA, L. Proposta de metodologia para avaliação do parâmetro 'Atividade MetanogênicaEspecífica. In: $19^{\circ}$ Congresso Brasileiro de Engenharia Sanitária e Ambiental,ABES, Foz do Iguaçu, 1997.

MOTER, A.; GöBEL, U. B. Fluorescence in situ hybridization (FISH) for direct visualization of microorganisms. J. Microbiol Methods 41, 85-112p., 2000.

MUYZER, G.; De WAAL, E.C.; UITTERLINDEN, A.G. Profiling of complex microbial populations by denaturing gradient gel electrophoresis analysis of polymerase chain reaction-amplified genes coding for 16S rRNA. Appl. Environ. Microbiol. 59: 695-700, 1993.

NANDY, T.; SHASTRY, S.; KAUL, S.N. (2002).Wastewater management in a cane molasses distillery involving bioresource recovery.Journal of Environmental Management, 65, p.25-38.

NATION, J.L. (1983). A new method using hexamethyldisilazane for preparation of soft tissues for scanning electron microscopy. Stain Technology, 58: 347-351. 
NIELSEN, T. A.; LIU, W-T, FILIPE, C.; GRADY, L.; MOLIN, S.; STAHL, D. A. (1999).Identification of a novel group of bacteria in sludge from a deteriorated biological phosphorus removal reactor. Appl. Environ. Microbiol., v. 65 , p. 12511258.

NOGUEIRA, L. A. H. Biodigestão a alternativa energética. São Paulo: Nobel, 1992. 93p.

NüBEL, U. et al. 1996. Sequence heterogeneities of genes encoding 16S rRNAs in Paenibacilluspolymyxa detected by temperature gradient gel electrophoresis. J. Bacteriology, p. 5636-5643,Vol. 178.

PARKIN, J.F.; OWEN, W.F. (1986). Fundamentals of anaerobic digestion of wastewater sludge. J. Environ. Eng. Div. Amer. Soc. Civil Eng., 122, p.867-920.

PENNA, J.A. (1994). Estudo da Metodologia do Teste de Atividade Metanogênica Específica. Tese (Doutorado em Engenharia Hidráulica e Saneamento), Universidade de São Paulo, São Carlos/SP.

PEREIRA-RAMIREZ, O.; QUADRO, M.S.; ANTUNES, R.M.; KOETZ, P.R. (2004). Influence of recirculation flow and alkalinity on the performance of an UASB reactor on piggery slurry treatment. Revista Brasileira de Agrociência, 10: 103-110.

PINHATI, F. R. Caracterização molecular da população bacteriana do lodo de Refinaria de Petróleo por PCR-DGGE e RAPD. Instituto de Química, Universidade Federal do Rio de Janeiro. Rio de Janeiro, 2008.105p.

PINTO, C.P. (1999). Tecnologia da digestão anaeróbia da vinhaça e desenvolvimento sustentável. Dissertação (Mestrado). Faculdade de Engenharia Mecânica da Universidade Estadual de Campinas. Campinas/SP.

PIVELI, R. P. Tratamento de Efluentes de Usinas do Setor Sucroalcooleiro. Universidade de São Paulo. Escola politécnica. Departamento de Engenharia Hidráulica. Junho/2006.

POLANCO, F.F.; POLANCO, M.F.; FERNADEZ, N.; URUENÃ, M.A.; GARCIA, A.G.; VILLAVERDE, S. (2001). New process for simultaneous removal of nitrogen and sulphur under anaerobic conditions. Water Research, 35 (4), p.1111-1114. 
POHLAND, F.G., HARPER, S. R. (1986). Critical review and summary of leachate and gas production from landfills.U.S. Environmental Protection Agency, Cincinnati, OH, U.S.A.

RIBAS, M.M.F. (2006). Tratamento de vinhaça em reator anaeróbio operado em batelada sequencial contendo biomassa imobilizada sob condições termofílicas e mesofílicas. Tese (Doutorado) - Escola de Engenharia de São Carlos, Universidade de São Paulo, São Carlos/SP.

RIPLEY, L.E.; BOYLE, W.C.; CONVERSE, J.C. Improved alkalimetric monitoring for anaerobic digestion of high-strength wastes. Journal of water pollution control federation, v. 58, n.5, p. 406-411. 1986.

ROCHA, V.C. Processamento anaeróbio de vinhaça pré-tratada com biopolímero à base de cálcio. Dissertação (Mestrado) - Escola de Engenharia de São Carlos, Universidade de São Paulo. São Carlos, p.104. 2012.

ROCHA, V.C.; PIRES, E.C. Tratamento de vinhaça em reator anaeróbio de biomassa imobilizada após pré-tratamento físico-químico. . In: Anais do I Seminário Temático, Universidade de São Paulo, São Carlos, 2011.

ROSA, D.R. Avaliação da dinâmica populacional e desempenho de sistemas de tratamento anaeróbio de efluentes com alto teor de gordura submetidos aprétratamento enzimático em biorreatores de biomassa suspensa, granular e imobilizada. Tese (Doutorado), Departamento de Bioquímica, Universidade Federal do Rio de Janeiro. 142p. Rio de Janeiro, 2008.

ROSENBERG, E.; DELONG, E. F.; LORY, S.; SKATEBRANT, E., THOMPSON, F. The Prokaryotes. 4nd. New York: Ed. Springer. 2014.

ROSSETTO, A. J. Utilização agronômica dos subprodutos e resíduos da indústria açucareira e alcooleira. In: Paranhos, S.B. (ed.). Cana-de-açúcar: cultivo e utilização. Campinas:Fundação Cargill, v.2, p.435-504, 1987.

SANTANA JÚNIOR, A.E. (2013). Produção de metano a partir de vinhaça e melaço em reatores UASB termofílicos, em dois estágios. Dissertação (Mestrado). Universidade Estadual Paulista. Jaboticabal, SP. 84p. 
SATYAWALI, Y.; BALAKRISHNAN, M. ( 2008). Treatment of distillery effluent in a membrane bioreactor (MBR) equipped with mesh filter. SeparationandPurification Technology 63, 278-286.

SIERRA-ÁLVAREZ, R.; Lettinga, G. The methanogenic toxicity of wastewater lignins and lignin-related compounds. J. Chem. Technol. Biotechnol 1991; 50: 443-55.

SIQUEIRA, L.M. (2007). Degradação anaeróbia da vinhaça em reator de leito fluidizado. Dissertação (Mestrado). Universidade Federal de São Carlos - UFSCar, São Carlos, SP.

SILVA, A.J.; DOMINGUES, MR.; HIRASAWA, J.S.; VARESCHE, M.B.; FORESTI, E.; ZAIAT, M. (2011). Kinetic modeling and microbial assessment by fluorescent in situ hybridization in anaerobic sequencing batch biofilm reactors treating sulfate-rich wastewater. Brazilian Journal of Chemical Engineering, v. 28, No. 02, pp. 209 -

SOARES, H. M.; HIRATA, Y. S. Classroom practice. In: Course of biological treatment of waste, 4., 30 jun. - 11 jul., Florianópolis. Proceedings... [S.1.]: CBAB MCT/CNPQ ALFA FURB CPGENQ/UFSC, 1999. 25 p.

SOUZA, F.A.F. (2011). Adaptação de lodo sanitário e industrial ao tratamento do vinhoto. Dissertação (Mestrado em Engenharia Civil e Ambiental). Universidade Federal de Campina Grande, Campina Grande/PB, 96p.

SCHMITT, F; WESCHENFELDER, S.; VIDI, T.M. Tratamento anaeróbio de efluentes. Departamento de Engenharia Química e de Alimentos, Universidade Federal de Santa Catarina, 2006.

SPEECE, R. E. (1996). Anaerobic Biotechnology for Industrial Wastewaters, Archae Press, Tennessee, USA, p.393.

STRAÜBER, H.; LUCAS, R., KLEINSTEUBER, S. Metabolic and microbial community dynamics during the anaerobic digestion of maize silage in a two-phase process. Applied Microbiology and Biotechnology, 2016, 100, p 479-491.

SZYMANSKI, M.S.; BALBINOT, R. Utilização do sistema de biodigestão anaeróbio para a vinhaça. In: Anais VI Semana de Estudos de Engenharia Ambiental, Irati/PR, 2008. 
TICM, Spanish Ministry of Tourism, Trade and Industry, 2007.Spanish Royal Decree R.D 661/2007, de 25 de Mayo, por el que se regula laactividad de producción de energíaeléctricarégimen especial. BOE 126, 22846-22886 (in Spanish).

UYANIK, S.; SALLIS, P. J.; ANDERSON, G. K.The effect of polymer addition on granulation in an anaerobic baffled reactor (ABR). Part II: compartmentalization of bacterial populations. Water Research, Oxford, v. 36, p. 944-955, 2002.

VALCKE, D.; VERSTRAETE, W.A practical method to estimate the acetoclastic methanogenic biomass in an-aerobic sludges. Journal of Water Pollution Control Federation 55, 1191-1195, 1983.

VAN HAANDEL, A.; LETTINGA, G. (1994). Tratamento anaeróbio de esgotos: Um manual para regiões de clima quente. Campina Grande, PB, 1994.

VAN HAANDEL, A.C. Integrated energy production and reduction of the environmental impact at alcohol distillery plants, Water Science and Technology 52 (1-2), p. 49-57, 2005.

VAZOLLER, R. F. Microbiologia e saneamento ambiental. Disponível em: http://www.bat.org.br/martinez/padct.bio/cap.9/rosana, acesso em: 15 de janeiro de 2013.

VERSIANI, B. M. Desempenho de um reator UASB submetido a diferentes condições operacionais tratando esgotos sanitários do campus da UFRJ. 78f. Dissertação (Mestrado - Programa de Pós Graduação de Engenharia)- UFRJ /COPPE da Universidade Federal do Rio de Janeiro/RJ, 2005.

WILKIE, A. C.; RIESEDEL, K. J.; OWENS, J.M. (2000).Stillage characterization and anaerobic treatment of ethanol stillage from conventional and cellulosic feedstock. Biomass and Bioenergy, August 2000, vol. 19, no. 2, p. 63-102.

WOESE, C.R. Bacterial evolution. Microbiological Reviews.v.51, n.2, p221-271, 1987. YANG, E Y. \& MOENGANGONGO, T. H. (1987). Operational stability of a horizontally-baffled anaerobic reactor for diluted swine wastewater in the tropics.Trans. Am. Soc. Agric. Eng., 30 (4) 1105-10.

YOUNG, J.C.; McCARTY, P.L.The anaerobic filter for waste treatment.Journal WPCF. v. 41, n. 5 , p. $160-173,1969$. 
ZAIAT, M. (2004). Desenvolvimento e análise de biorreatores anaeróbios contendo células imobilizadas para tratamento de águas residuárias. Tese (Livre Docência). Universidade de São Paulo. Departamento de Hidráulica e Saneamento (EESC/USP). São Carlos/SP.

ZILLI, J.E. et al. Diversidade microbiana como indicador de qualidade do solo. Cadernos de Ciência \& Tecnologia 